Portland State University

PDXScholar

\title{
The Metropolitan-Nonmetropolitan Turnaround in the Pacific States (California, Oregon, and Washington): Labor Migration Flows and Economic Deconcentration
}

Beverly Marie McLean

Portland State University

Follow this and additional works at: https://pdxscholar.library.pdx.edu/open_access_etds

Part of the Urban, Community and Regional Planning Commons Let us know how access to this document benefits you.

\section{Recommended Citation}

McLean, Beverly Marie, "The Metropolitan-Nonmetropolitan Turnaround in the Pacific States (California, Oregon, and Washington): Labor Migration Flows and Economic Deconcentration" (1992). Dissertations and Theses. Paper 1287.

https://doi.org/10.15760/etd.1286

This Dissertation is brought to you for free and open access. It has been accepted for inclusion in Dissertations and Theses by an authorized administrator of PDXScholar. Please contact us if we can make this document more accessible: pdxscholar@pdx.edu. 


\title{
THE METROPOLITAN-NONMETROPOLITAN TURNAROUND IN THE PACIFIC STATES (CALIFORNIA, OREGON, AND WASHINGTON): LABOR MIGRATION FLOWS \\ AND ECONOMIC DECONCENTRATION
}

\section{by}

BEVERLY MARIE MCLEAN

A dissertation submitted in partial fulfillment of the requirements for the degree of

\author{
DOCTOR OF PHILOSOPHY \\ in \\ URBAN STUDIES
}

\author{
Portland state University \\ 1992
}


TO THE OFFICE OF GRADUATE STUDIES:

The members of the committee approve the dissertation of Beverly Marie McLean presented March 4, 1989.

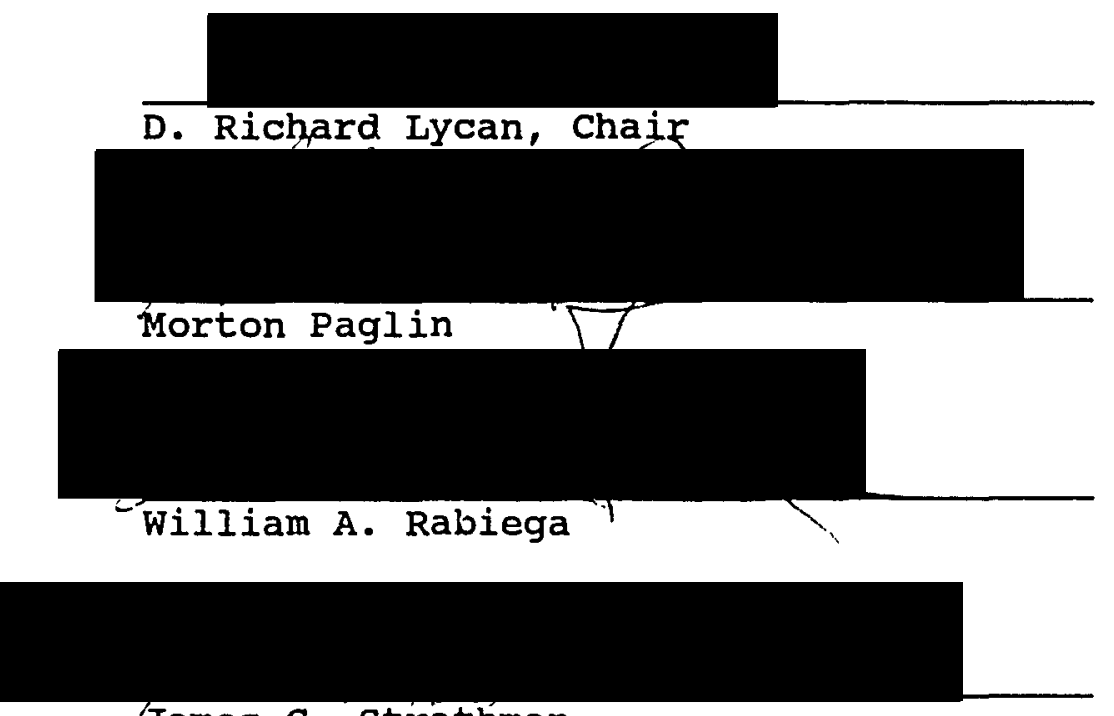

James G. Strathman
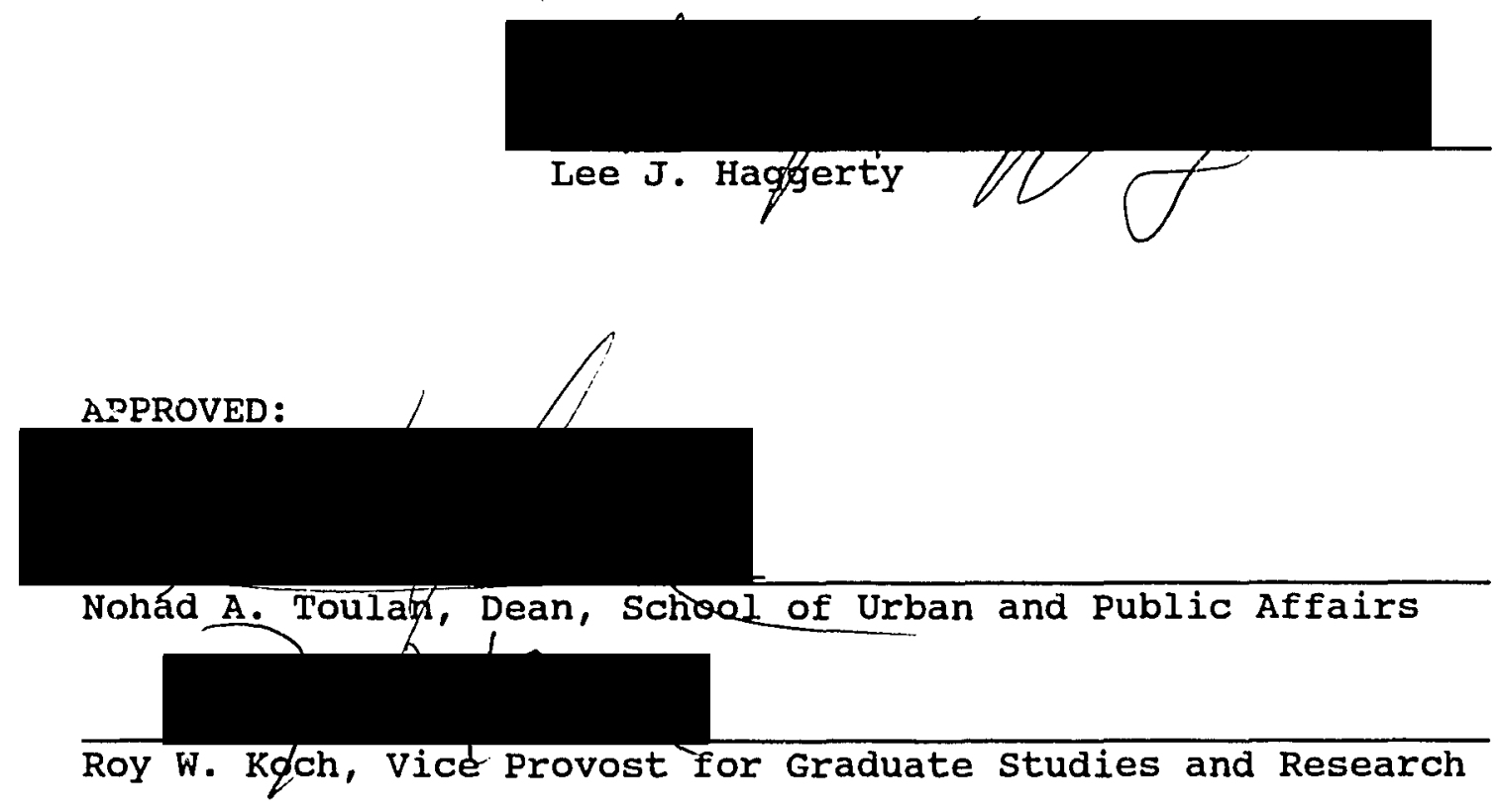
ACKNOWLEDGEMENTS

I would like to acknowledge and thank very much the patience and understanding of my dissertation chair for his time and effort to help me finally complete my dissertation. I also owe thanks to the constructive criticism from my other committee members, in particular Dr. James strathman and my outside examiner Dr. Lee Haggerty. Several others deserve special thanks. I owe a great gratitude to the staff of the Center for Population and Research at Portland state University for their time in helping me locate data sources, write programs to read my computer tape, and the use of their facilities (I am extremely grateful for the help I received from Edward Schafer and David Gardner). Special thanks need to go to David Perry and Sam cole at the State University of Buffalo for allowing me to use the Center for Regional studies facilities to complete my dissertation. I also would like to acknowledge the special help of University of Buffalo's Architecture and Planning Librarian Mannie Lopez. Lastly, my family and friends should be thanked for just being patient with me throughout this long drawn out process. 
TABLE OF CON'TENTS

PAGE

ACKNOWLEDGEMENTS. . . . . . . . . . . . . . . . iii

LIST OF TABLES. . . . . . . . . . . . . . . . . viii

IIST OF FIGURES . . . . . . . . . . . . . . . . . . . xi

CHAPTER

I INTRODUCTION . . . . . . . . . . . . 1

Research Process . . . . . . . . 9

Outline of the Dissertation. . . . . 10

II THE CONTEXT OF THE NONMETROPOLITAN

TURNAROUND: A REVIEW OF U.S.

MIGRATION FLOWS. . . . . . . . . . 12

Population Change in the Pacific coast states . . . . . . . . 18

Employment Change in the Pacific coast states......... . . 31

The spatial Context of the Pacific Region . . . . . . . . . . . 32

Chapter Summary and Conclusions. . . . 46

III THE THEORETICAL REVIEW OF MIGRATION

LITERATURE . . . . . . . . . . . . 48

Why the Turnaround of People and Jobs. - 48

Industrial Restructuring . . . . . . 50

Population Deconcentration . . . . . 55

Motivations for Migration: The Individual's Response to Structural

Change . . . . . . . . . . . 
Chapter Summary and Conclusions. . . . 64

IV MODEL SPECIFICATION FOR LABOR FORCE MIGRATION AND ECONOMIC

DECONCENTRATION. . . . . . . . . . 67

Hypotheses . . . . . . . . . . . 70

Environmental Amenities Attributes . . 72

Accessibility. . . . . . . . . . 73

Economic Activities. . . . . . . . 74

Model Specification. . . . . . . 75

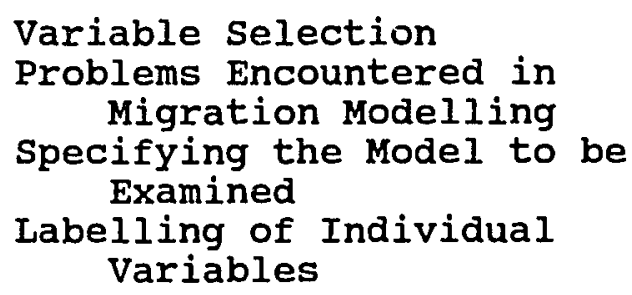

Data Sources . . . . . . . . . . 91

Secondary Data Collection Process. . . 93

Chapter Summary and Conclusions. . . 100

V EMPIRICAL RESULTS OF MODEL CALIBRATIONS. • - 102

Model Selection. . . . . . . . . 103

Testing the Migration Model Results

for Temporal Change. . . . . . . 105

The Nonadjacent Models . . . . . . 107

The Adjacent Nonmetropolitan Counties. . 119

Smaller Metropolitan Model County Results. . . . . . . . . . . 129

The Larger Metropolitan Counties . . . 138

Testing the Push and Pull Models for Spatial Differences. . . . . . . 147

A Comparison of Spatial Model Results. • 147 The Metropolitan Diffusion Model . . . 158 
symmetry Tests for In- and outMigration Models . . . . . . . 161

Chapter summary and Conclusions . . . 163

Research Findings. . . . . . . . 166

A Growing Importance of Environmental

Amenities and Environmental

Disamenities . . . . . . . . . 170

Nonadjacent Nonmetropolitan Counties

Adjacent Nonmetropolitan

Counties

Smaller Metropolitan Counties

Larger Metropolitan Counties

The Declining Importance of

Unemployment . . . . . . . . . . 173

Declining Income Differentials over

Time.............. 174

The Influence of Spatial Interaction . . 175

Differential Impacts of Economic

Deconcentration. . . . . . . . 175

Nonadjacent Counties

Adjacent Counties

Smaller Metropolitan Areas

Larger Metropolitan Areas

Higher Wages Stimulate Nonmetropolitan

Growth: Lower Wages Stimulate

Metropolitan Growth. . . . . . . 180

A Reconfiguration of Central Place Activities . . . . . . . . . . . 181

The Importance of Retirement . . . . 183

The Importance of Access . . . . . . 183

A Comparison of the Labor Flow Models with the Population Flow Models. . 183

Limitations of the Labor Flow Models . 185 
Further Comments--Barriers to

Mobility . . . . . . . . . . 188

Data Limitations . . . . . . . . 190

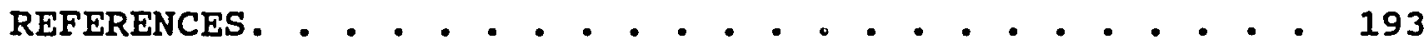
APPENDICES

A THE MODELS USED TO CALCULATE THE LABOR POTENTIAL. . . . . . . . . . . . . 218

B A COMPARISON OF THE CONTROLLED AND UNCONTROLLED ADJACENT MODELS. . . . . . 220

C E TESTS OF MODELS . . . . . . . . . . . 223

D LIST OF STANDARD ERRORS OF THE MODEL

RESULTS •. . . . . . . . . . . . . . 230 


\section{LIST OF TABLES}

TABLE

PAGE

I

II

III

IV

V

VI

VII

VIII

IX

$\mathrm{X}$

$\mathrm{XI}$

XII

XIII

XIV

County Names By Spatial Region . . . . 6

Interregional Migration, 1965-1970 and 1970-1975. . . . . . . . . . 16

U.S. Metropolitan and Nonmetropolitan Migration, 1965-1980 . . . . . . 17

Population Change in the Pacific states, 1960-1975. . . . . . . . 20

Labor Migrant Flows, 1965-1975 . . . . 27

Employment Concentration: Location Quotients for the Major Industrial Sectors, 1975........... 35

Employment by Major Industrial Sectors, 1965 • • • • • • • • • . • • . 37

Employment by Major Industrial Sectors, 1970 . . . . . . . . . .

Employment by Major Industrial Sectors, 1975 • • • • • • • • • • • • • 39

Employment Change in Pacific states, 1965-1970.

Employment Change in Pacific states, 1970-1975.

Enployment by Major Industrial Sectors by county Types, 1965-1975 ... . . 44

Employment Change by county Types by Major Industrial sectors, 1965-1975.

Industrial classification Used to Identify Employment Activity Variables. . . . . . . . . . 
Identification of Variables Used to Measure Nonroutine Manufacturing . . 84

XVI

The Expected Relationship of Specified Variables with Labor Migration.

XVII

Nonadjacent Counties Labor Migration Model. . . . . . . . . . 109

XVIII Nonadjacent Basic Employment Model . . 110

$\mathrm{XIX}$

Nonadjacent Nonbasic Employment Model. • 111

$\mathrm{XX}$

Adjacent Counties Migration Model. . . 121

$\mathrm{XXI}$

Adjacent Counties Basic Employment Model. . . . . . . . . . . 122

XXII Adjacent Nonbasic Employment Model . . 123

XXIII Metro < 500,000 Counties Labor Migration Model. . . . . . . 131

XXIV Metro < 500,000 Basic Employment Model . 132

XXV Metro < 500,000 Nonbasic Employment Model. . . . . . . . . . 133

XXVI Metro > 500,000 Counties Labor Migration Model. . . . . . . 139

XXVII Metro > 500,000 Counties Basic Employment Model . . . . . . . 140

XXVIII Metro > 500,000 Nonbasic Employment Model. . . . . . . . . . . . 141

$\mathrm{XXIX}$

Nonmetropolitan Counties Labor Migration Model, 1970-1975 . . . . 149

XXX Metropolitan Counties Labor Migration Model, 1970-1975 . . . . . . 150

XXXI Nonmetropolitan Basic Employment Model, 1970-1975. . . . . . . . . . 152

XXXII Metropolitan Basic Employment Model. • 153

XXXIII Nonmetropolitan Nonbasic Employment Model. . . . . . . . . . 156 
XXXIV Metropolitan Nonbasic Employment

Model. . . . . . . . . . . 157

XXXV Labor Migration Flow Matrix by origin and Destination County Types for the States of California, oregon, and washington, 1970-1975. . . . . . 160

XXXVI The Difference Between the Expected and the Actual Relationship of Specified Variables with Labor Migration. . . . . . . . . . 170 


\section{LIST OF FIGURES}

\section{FIGURE}

PAGE

1.

Map of state of California (U.S. Department of Commerce, Bureau of Census [U.S. Census], 1967c, Appendix) . . . . . . . . . . . 3

2. Map of state of oregon (U.S. Census, 1967c, Appendix) .. . . . . . . 4

3. Map of State of Washington (U.S. Census, 1967c, Appendix). . . . . 5

4 .

The Ecological Relation of Labor Migration. . . . . . . . . 70

5. Labor Potential Index. . . . . . . 79

6. Employment Growth Specification. . . . 85 
AN ABSTRACT OF THE DISSERTATION OF Beverly Marie McLean for the Doctor of Philosophy in Urban Studies presented March 4, 1989.

Title: The Metropolitan-Nonmetropolitan Turnaround in the Pacific States (California, Oregon, and Washington): Labor Migration Flows and Economjc Deconcentration.

APPROVED BY THE MEMBERS OF THE DISSERTATION COMMITTEE:

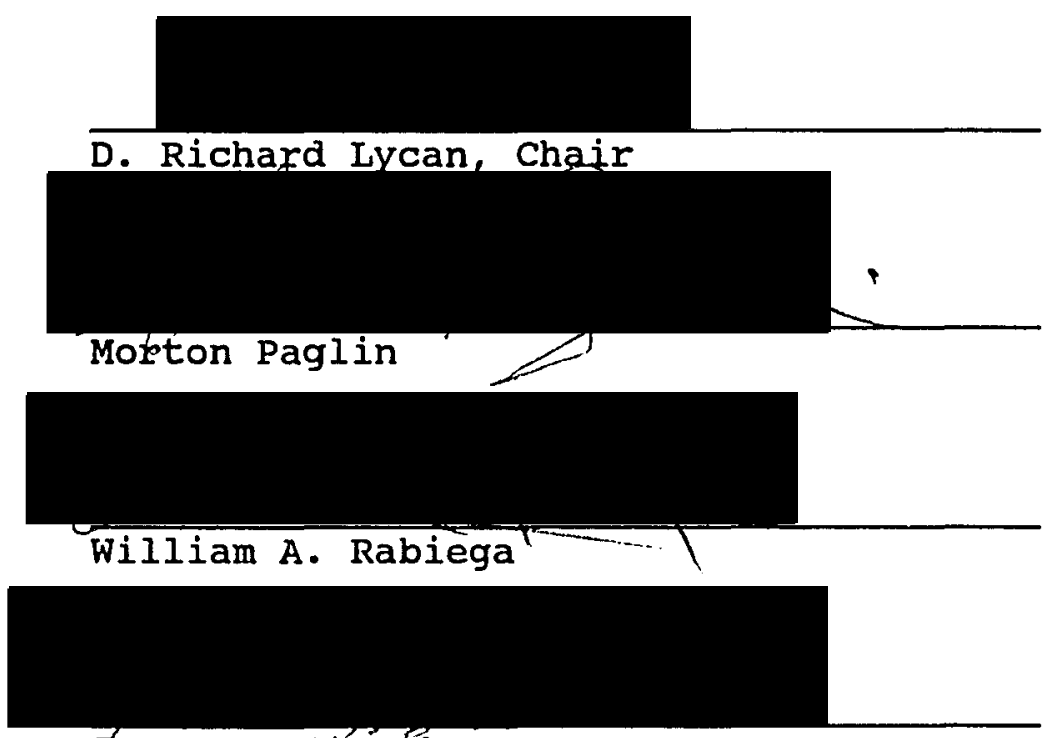

James G. Strathman

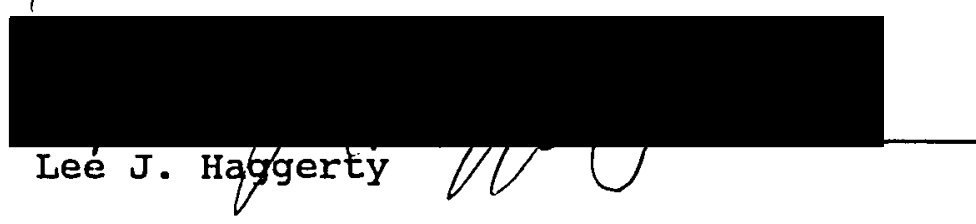

This dissertation examines the turnaround of labor force migration patterns in the states of California, Oregon, and Washington in the 1970s. The focus of the 
dissertation is the simultaneous phenomena of economic deconcentration and employment migration in nonmetropolitan counties during the turnaround period.

The theoretical approach of the research draws from the disciplines of economics, geography, and sociology to develop a model that addresses what attributes of areas attract labor migration flows. The study specifies that labor migration is a function of economic activities, the environment, and accessibility.

The research focus is the role that economic and noneconomic factors play in attracting labor migration flows. The spatial focus is the counties in the states of California, Oregon, and washington. The temporal focus of study is the period between 1965 and 1975 .

The results of the research affirm the complexity of migration modelling. A test of equality of coefficients of the different periods investigated show significant differences between the turnaround and preturnaround models. The data results show just a few of the noneconomic factors are a major determinant of the nonmetropolitan turnaround. The model results show several unexpected results. Several of the coefficients in the models have the opposite sign of what originally was expected. Another unexpected outcome of the research is the apparent symmetry of labor in-migration and labor out-migration coefficients. A formal 
test for symmetry, however, shows the models are significantly different.

This study finds that the economic deconcentration process in the Pacific states is not one in which metropolitan growth spilled over into the nonmetropolitan counties. Rather both the metropolitan and nonmetropolitan counties simultaneously experienced deindustrializing (a decline of manufacturing employment and growth of service employment). The service related employment activity has a major influence on employment growth in the Pacific states. Although employment change does not show a significant influence on labor migration flows, labor migration does show a significant influence on employment growth in several of the model results. 
CHAPTER I

\section{INTRODUCTION}

This study examines the change in labor force migration patterns and its interrelationship with economic deconcentration of jobs in the states of California, Oregon, and washington. In particular, the focus is on the simultaneous phenomenon of economic migration and employment deconcentration in nonmetropolitan counties in the 1970s.

The focus of this study is on one aspect of population exchange, the migration of employed persons. Employed migrants play a significant role in population exchange between geographic regions. Studies by the U.S. Census Bureau show that $54.5 \%$ of all U.S. population moves between and within states are members of the civilian labor force when they move (Roseman, 1983). Of these migrants, $85.8 \%$ were employed when they move.

The temporal focus of this study is the period between 1965 and 1975. This period is selected because of the resurgence of population growth in U.S. nonmetropolitan counties in the 1970s. Demographic studies show that a decline in migration flows to U.S. metropolitan regions actually began to occur in the late 1960s (Beale, 1976; Brown \& Wardwell, 1980). Population estimates for counties 
by the U.S. Census Bureau for the years between 1960 to 1965 show that metropolitan counties gained more migrants than the nonmetropolitan counties gained. By 1969, it became apparent to demographers that a historical reversal in U.S. population flows started to happen (Beale, 1976; Brown \& Wardwell, 1980).

The spatial focus of this study is labor flows between metropolitan statistical areas and nonmetropolitan counties in the Pacific states of California, Oregon, and Washington (see Figures 1, 2, and 3). Metropolitan statistical areas are those metropolitan counties having a population of 100,000 and a central city of 50,000 in 1970 as defined by the U.S. Census Bureau. A metropolitan statistical area may consist of one or more counties. This study categorizes metropolitan statistical areas by whether its population is greater than 500,000 or not. Nonmetropolitan counties are thus a residual category, not metropolitan. Nonmetropolitan counties are classified by whether the county is spatially influenced by the larger metropolitan statistical areas. Large metropolitan influence is based on whether the county is adjacent and not separated by physical barriers from a large metropolitan statistical area. It is assumed adjacent counties have a higher incident of spatial interaction (i.e., commuting to work and shopping) with metropolitan areas than do nonadjacent counties. Table I lists the names of the individual counties by their county type for each of the three states. 


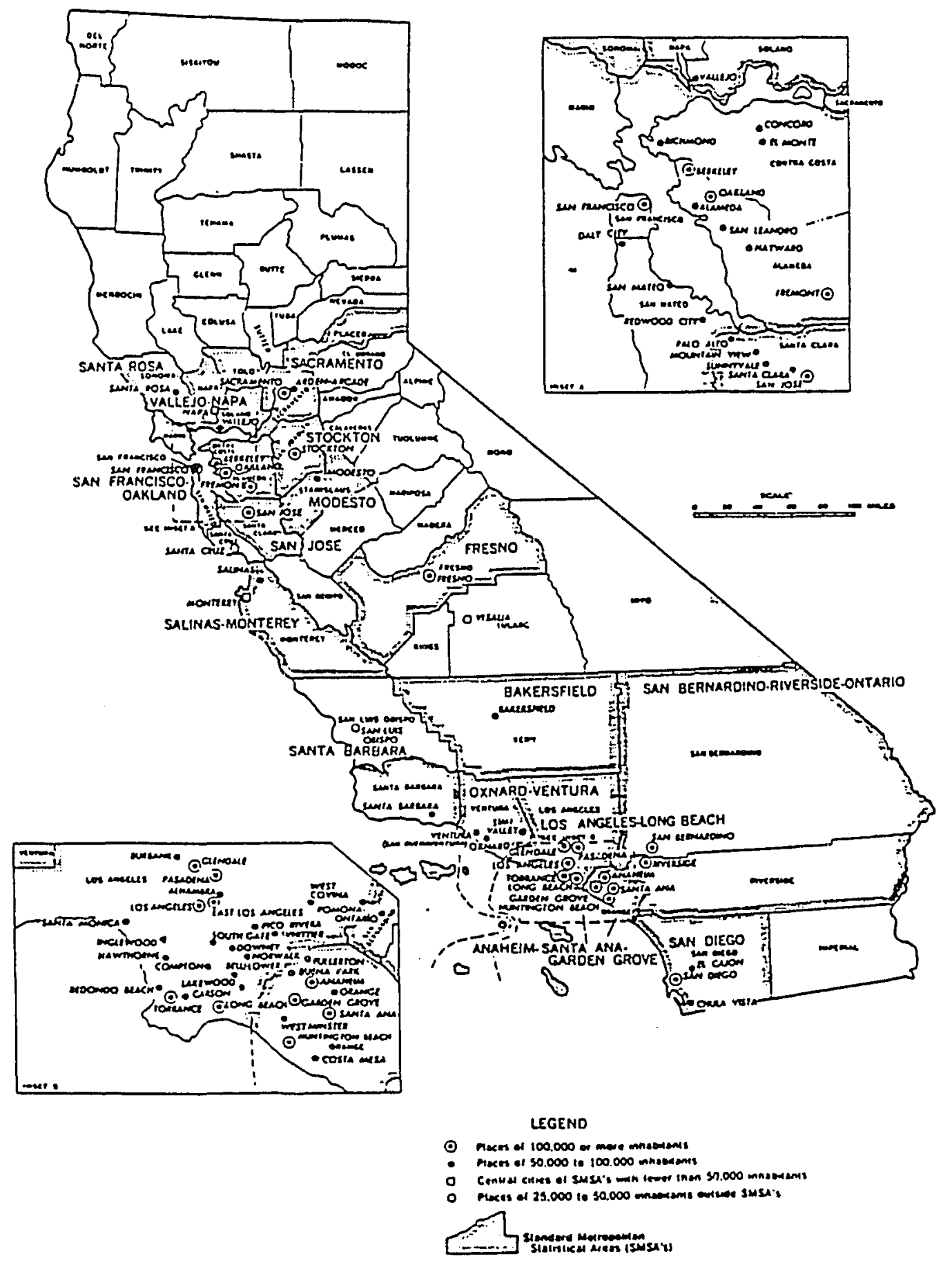

Figure 1. Map of state of California (U.S. Department of Commerce, Bureau of Census [U.S. Census], 1967c, Appendix). 


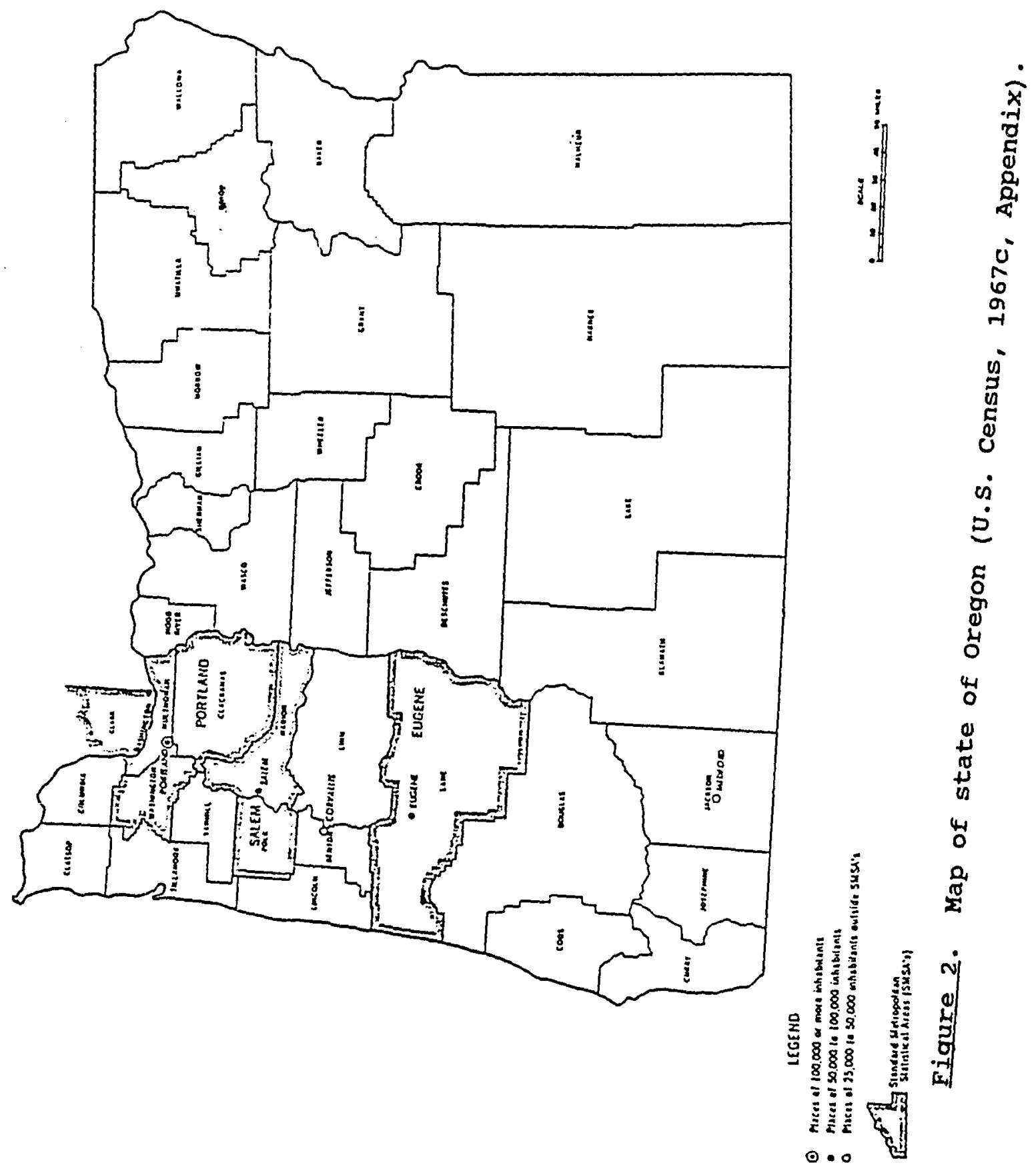




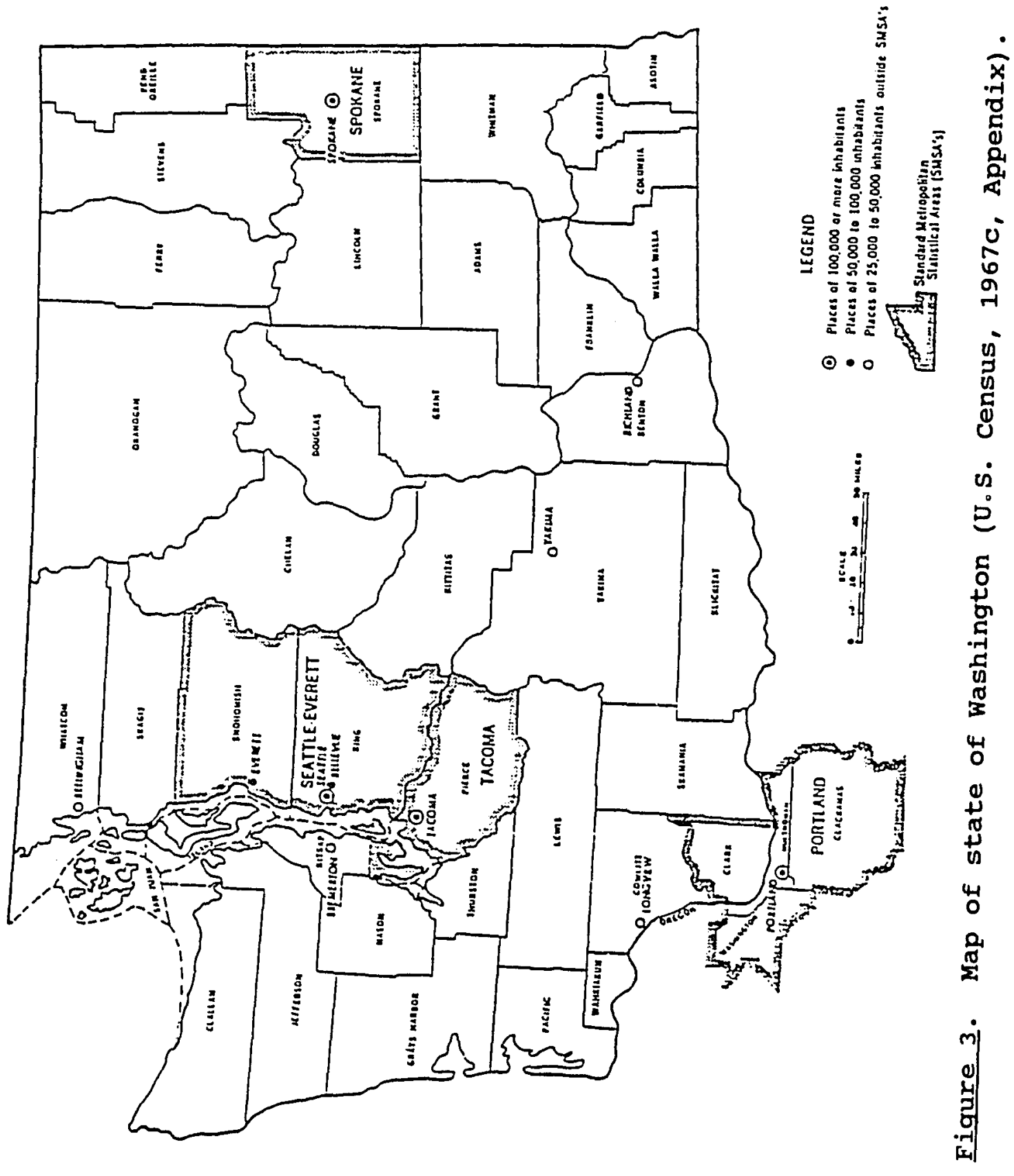


TABLE I

COUNTY NAMES BY SPATIAL REGION

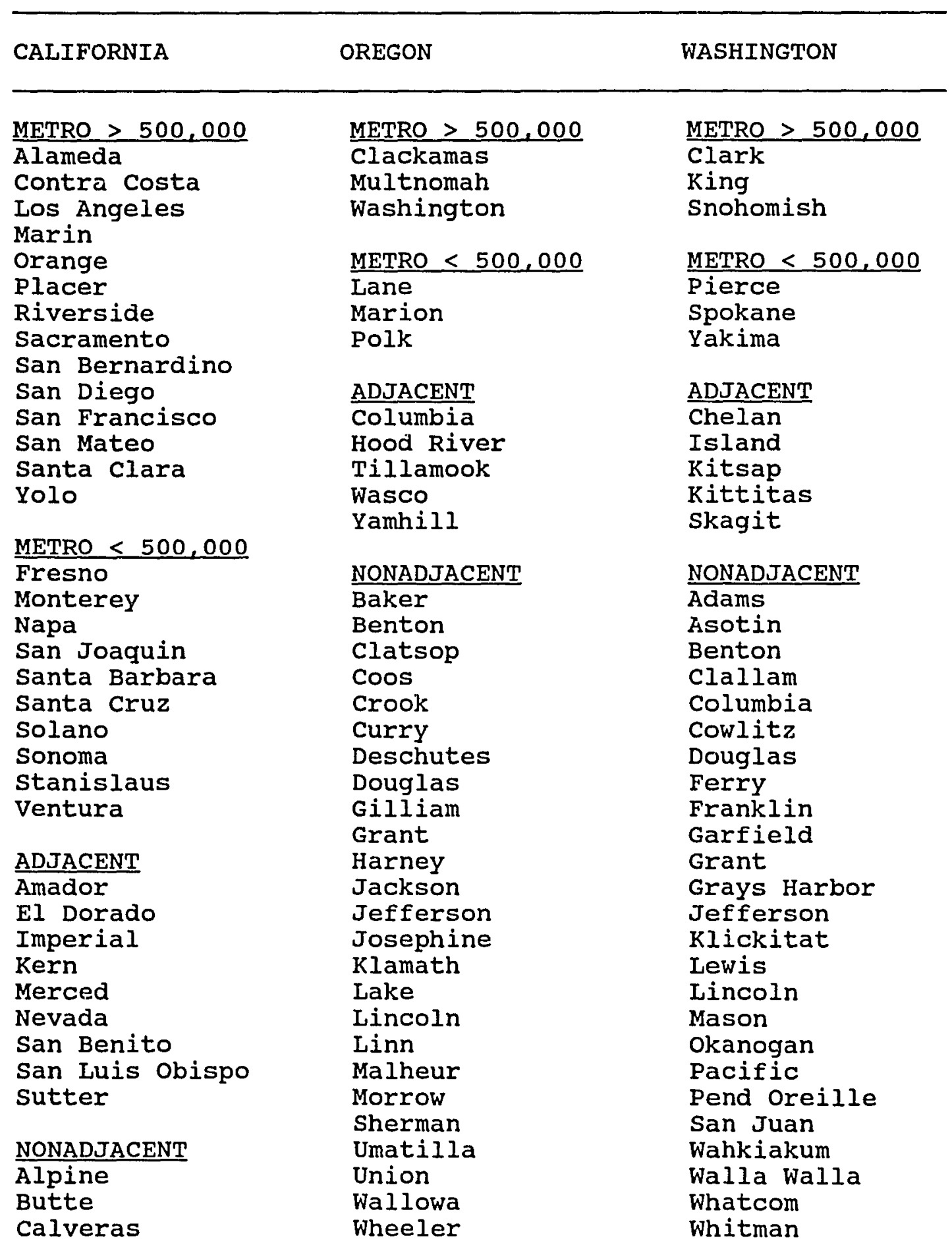


TABLE I

COUNTY NAMES BY SPATIAL REGION

(continued)

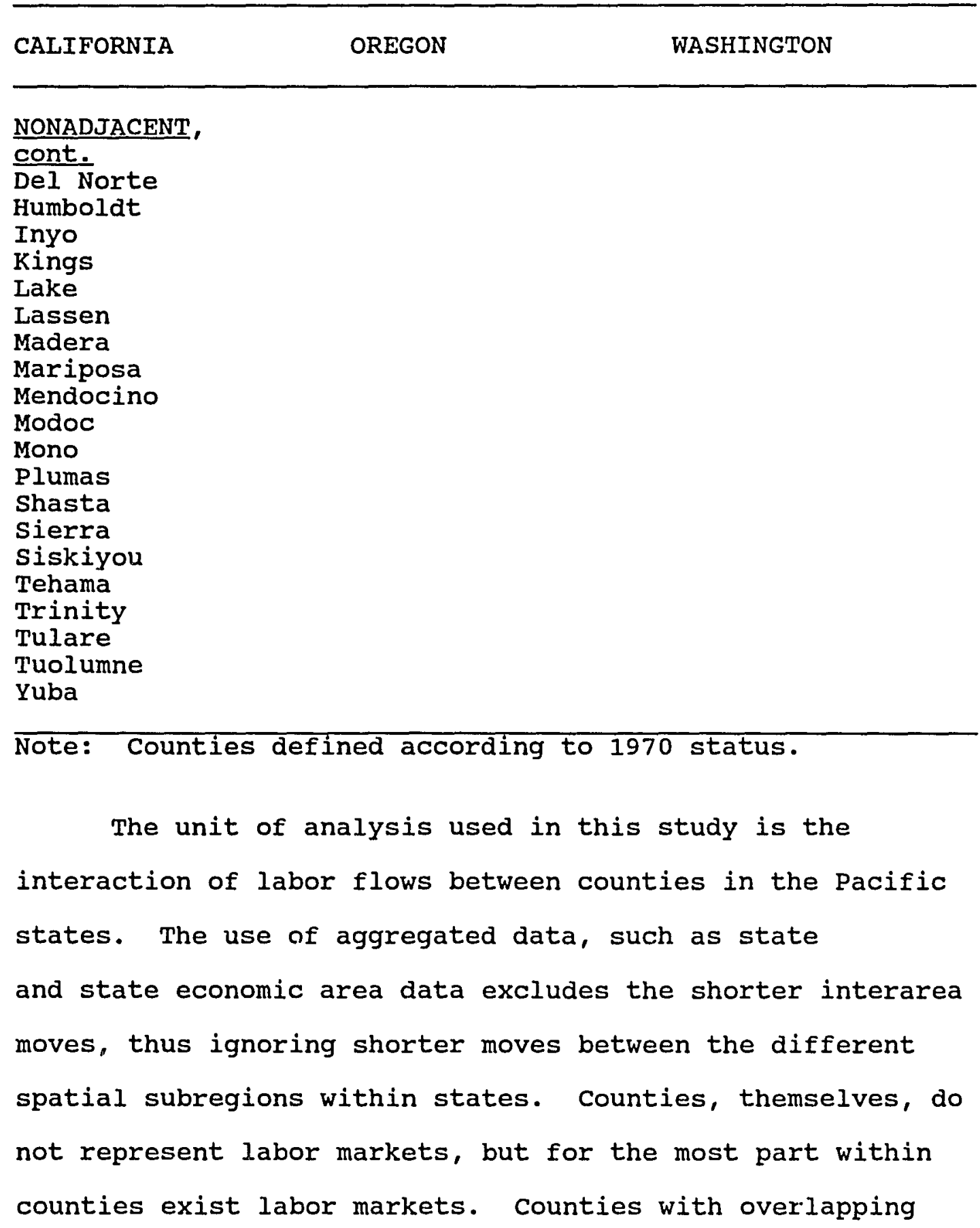


labor markets that are adjacent to large metropolitan statistical areas usually are classified by the U.S. Census Bureau as part of the metropolitan region, i.e., the Sacramento region includes Placer and Yolo counties. The source of data for labor flows is the continuous Work History one Percent Sample File (CWHS), which is compiled from Social security Administration records (U.S. Department of Commerce, Bureau of Economic Analysis [U.S. Economic], 1976a, 1976b). This data source contains information on such individual characteristics as gender, age, wage rates, and location of employment by county and industry for the three periods studied (1960-1965, 1965-1970, and 1970-1975).

This study draws from concepts in economics, geography, and sociology to develop a model that addresses what attributes of areas attract labor migration flows. The foci in economics usually are economic opportunities or rational economic decision making. In geography, the focus is the spatial interaction between geographical regions. In sociology, the foci are either motivations for migration, life-cycle changes, social mobility, or the ecological relationship between population and the environment. The goal of this study is to examine the importance of employment and nonemployment related factors to labor migration. Employment variables are taken from the neoclassical economic model, which states labor migration 
flows are from areas which have lower incomes or scarce job opportunities to areas which have higher incomes or plentiful job opportunities. Nonemployment variables are derived from sociological models that identify attributes in the socio-economic and physical environment that make an area more attractive to migrants. The spatial variables are derived from the spatial interaction model found in the geographical literature.

\section{RESEARCH PROCESS}

This study utilizes separate spatial models for the three different periods. For each period, models are estimated for metropolitan areas with populations greater than 500,000, metropolitan areas with populations less than 500,000 , nonmetropolitan counties adjacent to the larger metropolitan counties, and nonmetropolitan counties that are not adjacent to the larger metropolitan counties.

The research process involves the following steps:

1. Estimating a simultaneous labor flow model to test the determinants of labor in-migration flows and labor out-migration flows, not controlling for county of residence.

2. Testing the hypothesis that labor migration flows to nonmetropolitan regions is a by-product of diffusion of employment opportunities from the larger metropolitan to the 
nonmetropolitan nonadjacent counties, by controlling for county of residence.

\section{OUTLINE OF THE DISSERTATION}

Chapter II examines the context of the nonmetropolitan turnaround by briefly reviewing the historical migration patterns in the United States. In addition, Chapter II contrasts labor and population migration flows found in the three Pacific states with national and regional patterns of population and labor migration in the 1970 s.

Chapter III reviews the theoretical migration literature to develop a conceptual foundation for migration modelling. The theoretical review focuses on economic, geographical, and sociological literatures. The emphasis of the scholarly literature review is on the reasons for the noimetropolitan turnaround in migration of jobs and people.

Chapter IV describes the model specification for labor force migration and economic deconcentration. This chapter outlines the process of operationalizing, collecting, and processing data for testing the research models, as well as the limitations found in using the various data sources.

Chapter $V$ describes the results of the model calibrations for the labor migration models. Difficulties encountered in the model calibrations are also discussed.

Chapter VI presents the summary and conclusions of the study. This chapter discusses the implications of the model 
results and the model limitations. The chapter also compares and contrasts the calibration results for the labor migration flow model with the results for population flow models reported in the literature, as well as future research directions. 


\section{CHAPTER II}

THE CONTEXT OF THE NONMETROPOLITAN TURNAROUND:

A REVIEW OF U.S. MIGRATION FLOWS

To address the issue of the nonmetropolitan turnaround requires examining (a) the historical trends in U.S. settlement patterns, (b) changing economic trends in the 1970s, and (c) comparing the differences in economic and demographic trends between metropolitan and nonmetropolitan counties. This chapter contrasts and compares population and economic trends in the Pacific states with national patterns found in the pre-turnaround and turnaround periods.

To understand the significance and the consequences of the nonmetropolitan turnaround in the 1970s, it is important to look at the past migration trends and the social and economic structure of metropolitan and nonmetropolitan counties. Since the late nineteenth century, scholars have regarded rural to urban migration to be a reflection of social and economic change. The process of industrialization leads to rapid economic growth in urban centers and economic decline in their rural periphery. In the late nineteenth and the twentieth century, industrialization in the United states caused urban areas to be economically more attractive than rural areas. The shift from an agrarian to an industrial economy reduced the demand 
for farm labor, thus leaving few alternatives to agrarian employment in the nonmetropolitan counties. The lack of employment opportunities forced the out-migration of the young, even when surveys revealed residents preferred to live in nonmetropolitan counties (Lonsdale \& Seyler, 1979). One of the first scholars to theorize about migration was Ravenstein $(1885,1889)$. Seven laws of migration can be summarized from Ravenstein's work: (a) migrants tend to move short distances toward centers of industry and commerce, (b) dispersion is the inverse of absorption, (c) each migration flow produces a counter flow, (d) more females move shorter distances than males, (e) rural flows tend to be greater than urban flows, (f) there exists an interrelationship between technology and migration, and ( $g$ ) the predominant motive for migration is economic (Lee, 1966).

Until the 1970s, U.S. migration flows supported Ravenstein's hypothesis (Lee, 1966). From the works of Kasarda (1980), Sharpless (1980), and Wardwell and Brown (1980), four trends in migration flows can be synthesized for the United states. The first flow is the movement to the western frontier after the Revolutionary war until about 1890. In 1870, only $3 \%$ of ail Americans lived beyond the Appalachian region. By 1900, about 21 million people lived in the area beyond the Mississippi or $28 \%$ of the total population (Sharpless, 1980). 
The second flow is the migration movement during the period of industrialization between 1890 and 1940. In 1890, $7 \%$ of the U.S. population lived in cities over 50,000. BY $1920,31 \%$ of the U.S. population lived in cities over 50,000 and $15 \%$ lived in cities over 500,000 . The number of rural out-migrants consistently outnumbered the number of urban out-migrants during this period and continued to do so until 1970 (Kasarda, 1980).

The impetus for the movement away from rural regions comes primarily from changes within the structure of the agrarian economy. Changes in agrarian technology has brought increased mechanization of farms reducing the number of man-hours needed for total agricultural production. Because of the decrease in man-hours, America's major agricultural belts experienced a reduction in population growth. The U.S. Censuses of Population and Housing show a population decline of $27 \%$ for the U.S. Corn Belt and $36 \%$ for the U.S. Cotton Belts between 1940 and 1970 (Wardwell \& Brown, 1980).

A third migration flow is a movement away from the South during the period between 1940 and 1970. The U.S. Censuses for Population and Housing taken between the years of 1940 and 1970 show that the South had negative net migration with all other U.S. regions (Kasarda, 1980). A major proportion of the migrants who left the South was Afro-American during this period. In total, approximately 
three and a half million Afro-Americans left the South between 1940 and 1970 (Kasarda, 1980).

Recent studies on U.S. settlement patterns point to two new migration movements in the 1970s (Perry \& Watkins, 1977; Sawers \& Tabb, 1984). The first trend is a reversal of the migration away from the south and a consequent rise of the Sunbelt cities. Between 1970 and 1975, the South had a net gain of $1,829,000$ migrants compared to a net gain of 656,000 migrants between 1965 and 1970. The second movement is a reversal of the movement away from nonmetropolitan counties. For the first time in the twentieth century, there was net migration to nonmetropolitan counties. Metropolitan counties lost 1,594,000 migrants to nonmetropolitan counties between 1970 and 1975 and 1,344,000 migrants between 1975 and 1980 (see Tables II and III).

Berry (1976c) postulates that the population deconcentration process in the 1970 s represents a counterurbanization process. Berry defines counterurbanization as a process, which is ". . . a movement away from a state of more concentration to a state of less concentration" (p. 17).

Berry (1976c) notes that although some scholars claim the 1970s data represents a "temporary perturbation," this attitude is not credible (p. 24). According to Berry, throughout the 20 th century all trends have pointed - . to a trend [that] has been one leading unremittingly toward the reversal of the process 
of population concentration unleashed by technologies of the Industrial Revolution. (p. 24)

TABLE II

INTERREGIONAL MIGRATION, 1965-1970

AND 1970-1975

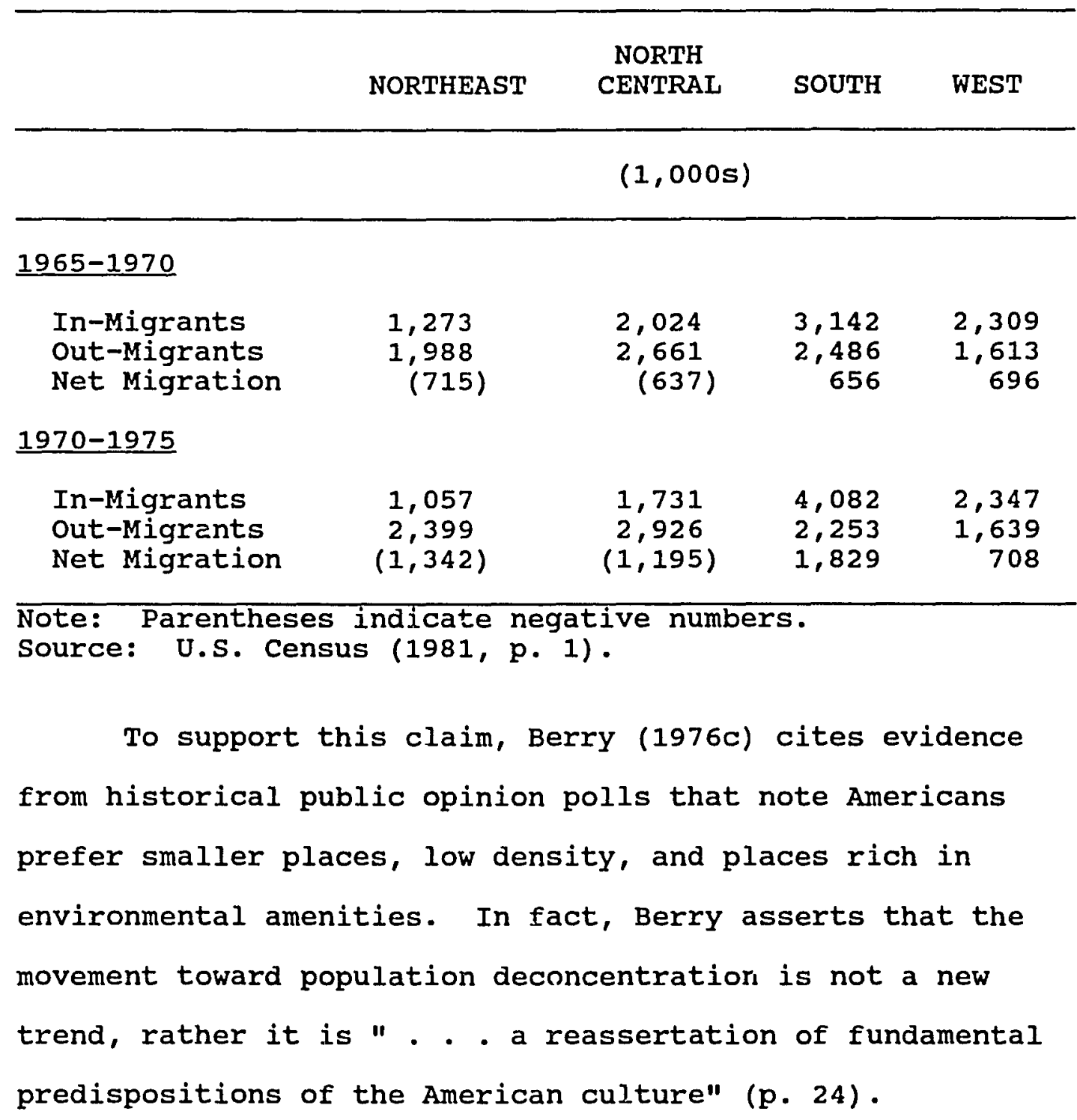


TABLE III

U.S. METROPOLITAN AND NONMETROPOLITAN

MIGRATION, 1965-1980

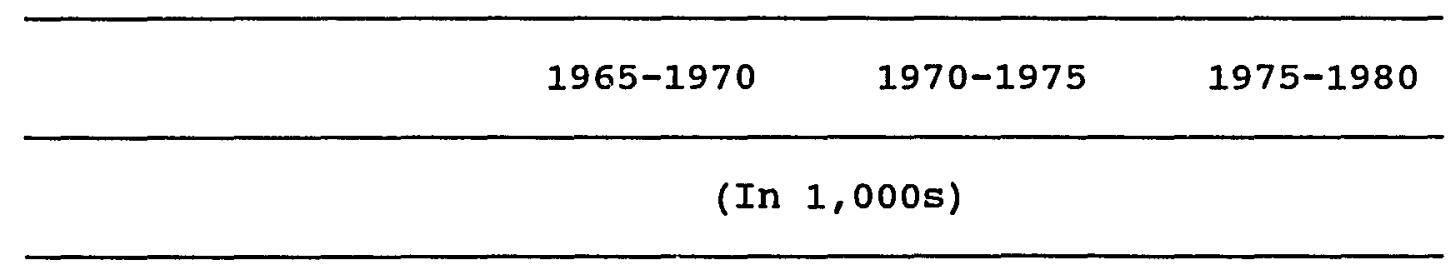

METROPOLITAN

In-Migrants

out-Migrants

Net Migration

NONMETROPOLITAN

In-Migrants

Out-Migrants

Net Migration

$\begin{array}{ccc}5,457 & 5,127 & 5,993 \\ 5,809 & 6,721 & 7,337 \\ (352) & (1,594) & (1,344)\end{array}$

5,457
5,809

$(1,594)$

Note: Parentheses indicate negative numbers.

Source: U.S. Census (1981, Table C).

This rural resurgence in the 1970 s was not just a phenomenon associated with the United States, but also happened elsewhere, i.e., Belgium, Denmark, Norway, and Sweden. Vining and Kontuly (1978) found similar rural urban migration patterns internationally during the turnaround period for other developed nations. The degree of similarity found in the international migration patterns suggested to Wardwell (1980) that research should concentrate on the factors that are common to all of these areas, and the focus should be on two distinct questions--"Why?" and "Why in the 1970s?" did this change happen. 
The amount of net migration in nonmetropolitan counties in the 1970 s varied according to the county's proximity to large metropolitan areas in the United states. Counties adjacent to large metropolitan areas had a net migration gain of $7.5 \%$ in the 1970 s compared to a net migration gain of $4.9 \%$ for the counties not adjacent to metropolitan areas. Within the West, the gains were higher than the national average, a gain of approximately $19.5 \%$ for adjacent counties and $12.1 \%$ for nonadjacent counties (Fuguitt, Voss, \& Doherty, 1979). The higher growth in adjacent counties may be a sign of spreading urbanization (Fuguitt, Voss, \& Doherty, 1979). The degree of nonmetropolitan growth in the west makes the region an ideal case study for the nonmetropolitan turnaround in the 1970s.

\section{POPULATION CHANGE IN THE PACIFIC COAST STATES}

The three Pacific states have had similar patterns of population change in the 1970 s as the rest of the western states had. Both adjacent and nonadjacent counties showed substantial population growth in the 1970s. Between 1970 and 1980 , counties with the highest rates of population growth in the Pacific states were nonmetropolitan counties. In California, the counties that had a population increase of more than $25 \%$ in order are Alpine, Nevada, Lake, El Dorado, Mariposa, Amador, Calaveras, and Trinity. Four of these counties were adjacent to the smaller metropolitan 
statistical areas (SMSAs); the rest of these counties are nonadjacent nonmetropolitan counties. In oregon, the counties with a population increase greater than $25 \%$ were Morrow, Josephine, and Deschutes (all of which are nonadjacent nonmetropolitan counties). In Washington, the counties with a population increase greater than $25 \%$ were San Juan, Benton, Ferry, Stevens, Thurston, Jefferson, and Island. One of these Washington counties was part of a smaller metropolitan statistical area, three were adjacent to metropolitan statistical areas, and the rest were nonadjacent nonmetropolitan counties (see Table IV). Population change has not been uniform in the Pacific nonmetropolitan counties. While several counties had rapid population growth, a few counties continued to lose population between 1970 and 1980. For instance, in California, both Colusa and king lost population. In oregon, the counties of Sherman and Wheeler lost population as well. In Washington, the counties of Adams, Columbia, Garfield, Kittitas, and Whitman all lost population. The large metropolitan areas in all three of the Pacific states lost a shift of population away from the core counties containing the central city to their suburban counties in the periphery. In California and oregon, all the core counties of the metropolitan statistical areas with a population over 500,000 lost population in the 1970s. In washington, however, both the core and suburban periphery 
TABLE IV

POPULATION CHANGE IN THE PACIFIC STATES, 1960-1975

\begin{tabular}{|c|c|c|c|c|c|c|c|}
\hline COUNTY & 1960 & 1965 & 1970 & 1975 & $\begin{array}{l}\text { CHANGE } \\
1960-1965\end{array}$ & $\begin{array}{l}\text { CHANGE } \\
1965-1970\end{array}$ & $\begin{array}{l}\text { CHANGE } \\
1970-1975\end{array}$ \\
\hline \multicolumn{8}{|l|}{ CALI FORHIA } \\
\hline \multicolumn{8}{|l|}{ KETRO > 500,000 } \\
\hline $\begin{array}{l}\text { ALAMEDA } \\
\text { CONTRA COSTA } \\
\text { LOS ANGELES } \\
\text { MARIN } \\
\text { ORANGE } \\
\text { PLACER } \\
\text { RIVERSIDE } \\
\text { SACRAMENTO } \\
\text { SAN BERNARDINO } \\
\text { SAN DIEGO } \\
\text { SAH FRANCISCO } \\
\text { SAH MATEO } \\
\text { SANTA CLARA } \\
\text { YOLO }\end{array}$ & $\begin{array}{r}908,209 \\
409,030 \\
6,038,771 \\
146,820 \\
703,925 \\
56,998 \\
306,191 \\
502,778 \\
503,591 \\
1,033,011 \\
740,316 \\
444,387 \\
642,315 \\
65,727\end{array}$ & $\begin{array}{r}1,022,700 \\
495,, 100 \\
6,766,700 \\
148,800 \\
1,144,100 \\
73,000 \\
405,400 \\
510,300 \\
620,208 \\
1,165,600 \\
742,200 \\
516,900 \\
900,700 \\
82,100\end{array}$ & $\begin{array}{r}1,071,446 \\
556,116 \\
7,041,980 \\
208,652 \\
1,421,233 \\
77,632 \\
456,916 \\
634,373 \\
682,233 \\
1,357,854 \\
715,, 674 \\
557,361 \\
1,065,313 \\
91,788\end{array}$ & $\begin{array}{r}1,090,600 \\
597,500 \\
6,958,900 \\
219,600 \\
1,703,000 \\
91,000 \\
528,900 \\
691,400 \\
696,800 \\
1,593,800 \\
669,100 \\
582,000 \\
1,178,500 \\
101,600\end{array}$ & $\begin{array}{r}114,491 \\
86,070 \\
727,929 \\
1,980 \\
440,175 \\
16,002 \\
99,209 \\
7,522 \\
116,617 \\
132,589 \\
1,884 \\
72,513 \\
258,385 \\
16,373\end{array}$ & $\begin{array}{r}48,746 \\
61,016 \\
275,280 \\
59,852 \\
277,133 \\
4,632 \\
51,516 \\
124,073 \\
62,025 \\
192,254 \\
(25,526) \\
40,461 \\
164,613 \\
9,688\end{array}$ & $\begin{array}{c}19,154 \\
41,384 \\
(83,080) \\
10,948 \\
281,767 \\
13,368 \\
71,984 \\
57,027 \\
14,567 \\
235,946 \\
(46,574) \\
24,639 \\
113,187 \\
9,812\end{array}$ \\
\hline TOTAL & $12,502,069$ & $14,593,808$ & $15,938,571$ & $16,702,700$ & $2,091,739$ & $1,344,763$ & 764,129 \\
\hline \multicolumn{8}{|l|}{ METRO $<500,000$} \\
\hline $\begin{array}{l}\text { FRESNO } \\
\text { MONTEREY } \\
\text { MAPA } \\
\text { SAN JOAQUIH } \\
\text { SANTA BARBARA } \\
\text { SANTA CRUZ } \\
\text { SOLANO } \\
\text { SONOMA } \\
\text { STANISLAUS } \\
\text { VENTURA }\end{array}$ & $\begin{array}{r}365,945 \\
198,351 \\
65,890 \\
249,989 \\
163,962 \\
84,219 \\
134,597 \\
147,375 \\
157,294 \\
199,138\end{array}$ & $\begin{array}{r}403,900 \\
224,400 \\
66,400 \\
272,300 \\
247,500 \\
108,100 \\
159,700 \\
182,500 \\
176,400 \\
311,300\end{array}$ & $\begin{array}{r}413,329 \\
247,450 \\
79,140 \\
291,073 \\
264,324 \\
123,790 \\
171,989 \\
204,885 \\
194,506 \\
378,497\end{array}$ & $\begin{array}{r}447,900 \\
269,700 \\
91,700 \\
299,400 \\
280,500 \\
156,600 \\
187,600 \\
187,600 \\
224,600 \\
440,500\end{array}$ & $\begin{array}{r}37,955 \\
26,049 \\
510 \\
22,311 \\
83,538 \\
23,881 \\
25,103 \\
35,125 \\
19,106 \\
112,162\end{array}$ & $\begin{array}{r}9,429 \\
23,050 \\
12,740 \\
18,773 \\
16,824 \\
15,690 \\
12,289 \\
22,385 \\
18,106 \\
67,197\end{array}$ & $\begin{array}{c}34,571 \\
22,250 \\
12,560 \\
8,327 \\
16,176 \\
32,810 \\
15,611 \\
(17,285) \\
30,094 \\
62,003\end{array}$ \\
\hline TOTAL & $1,766,760$ & $2,152,500$ & $2,368,983$ & $2,586,100$ & 385,740 & 216,483 & 217,117 \\
\hline
\end{tabular}


TABLE IV

POPULATION CHANGE IN THE PACIFIC STATES, 1960-1975 (continued)

\begin{tabular}{|c|c|c|c|c|c|c|c|}
\hline COUNTY & 1960 & 1965 & 1970 & 1975 & $\begin{array}{l}\text { CHAAGE } \\
1960-1965\end{array}$ & $\begin{array}{c}\text { CHANGE } \\
1965-1970\end{array}$ & $\begin{array}{l}\text { CHANGE } \\
1970-1975\end{array}$ \\
\hline \multicolumn{8}{|c|}{ CALIFORNIA， CONTINUED } \\
\hline \multicolumn{8}{|l|}{$\begin{array}{l}\text { ADJACENT } \\
-\end{array}$} \\
\hline $\begin{array}{l}\text { AMADOR } \\
\text { EL DORADO } \\
\text { IMPERIAL } \\
\text { KERN } \\
\text { MERCED } \\
\text { NEVADA } \\
\text { SAN BENITO } \\
\text { SAN LUIS OBISPO } \\
\text { SUTTER }\end{array}$ & $\begin{array}{r}9,990 \\
29,390 \\
72,105 \\
291,984 \\
90,446 \\
20,911 \\
15,396 \\
81,044 \\
33,380\end{array}$ & $\begin{array}{r}11,000 \\
41,700 \\
75,600 \\
321,400 \\
90,900 \\
21,200 \\
15,500 \\
97,700 \\
39,300\end{array}$ & $\begin{array}{r}11,821 \\
43,833 \\
74,492 \\
330,234 \\
104,629 \\
26,346 \\
18,226 \\
105,690 \\
41,935\end{array}$ & $\begin{array}{r}19,314 \\
59,200 \\
84,900 \\
347,500 \\
118,700 \\
34,000 \\
19,800 \\
128,900 \\
46,300\end{array}$ & $\begin{array}{r}1,010 \\
12,310 \\
3,495 \\
29,416 \\
454 \\
289 \\
104 \\
16,656 \\
5,920\end{array}$ & $\begin{array}{c}821 \\
2,133 \\
(1,108) \\
8,834 \\
13,729 \\
5,146 \\
2,726 \\
7,990 \\
2,635\end{array}$ & $\begin{array}{r}7,493 \\
15,367 \\
9,608 \\
17,266 \\
14,071 \\
7,654 \\
1,574 \\
23,210 \\
4,365\end{array}$ \\
\hline TOTAL & 644,646 & 714,300 & 757,206 & 857,814 & 69,654 & 42,906 & 100,608 \\
\hline \multicolumn{8}{|l|}{ HONAD JACENT } \\
\hline $\begin{array}{l}\text { ALPINE } \\
\text { BUTTE } \\
\text { CALVERAS } \\
\text { COLUSA } \\
\text { DEL NORTE } \\
\text { GLEHN } \\
\text { HUMBOLDT } \\
\text { INYO } \\
\text { KINGS } \\
\text { LAKE } \\
\text { LASSEH } \\
\text { MADERA } \\
\text { MARIPOSA } \\
\text { MENDOCINO } \\
\text { MOOOC } \\
\text { HONO } \\
\text { PLUMAS } \\
\text { SHASTA } \\
\text { SIERRA }\end{array}$ & $\begin{array}{r}397 \\
82,030 \\
10,289 \\
12,075 \\
17,771 \\
17,245 \\
104,892 \\
11,684 \\
49,954 \\
13,786 \\
13,597 \\
40,468 \\
5,064 \\
51,059 \\
8,308 \\
2,213 \\
11,620 \\
59,468 \\
2,247\end{array}$ & $\begin{array}{r}400 \\
100,700 \\
12,000 \\
12,200 \\
16,300 \\
18,400 \\
101,600 \\
13,900 \\
64,400 \\
13,900 \\
16,200 \\
40,700 \\
5,962 \\
51,000 \\
7,500 \\
4,367 \\
12,200 \\
73,100 \\
2,400\end{array}$ & $\begin{array}{r}484 \\
101,969 \\
13,585 \\
12,430 \\
14,580 \\
17,521 \\
99,692 \\
15,571 \\
66,717 \\
19,548 \\
16,796 \\
41,519 \\
6,015 \\
51,101 \\
7,469 \\
4,016 \\
11,707 \\
77,640 \\
2,365\end{array}$ & $\begin{array}{r}800 \\
120,500 \\
15,600 \\
12,600 \\
15,800 \\
19,300 \\
106,600 \\
17,400 \\
68,700 \\
25,700 \\
18,700 \\
47,000 \\
8,400 \\
59,300 \\
8,000 \\
7,300 \\
14,100 \\
92,400 \\
2,800\end{array}$ & $\begin{array}{r}3 \\
18,670 \\
1,711 \\
125 \\
(1,471) \\
1,155 \\
(3,292) \\
2,216 \\
14,446 \\
114 \\
2,603 \\
232 \\
898 \\
(59) \\
(808) \\
2,154 \\
580 \\
13,632 \\
153\end{array}$ & $\begin{array}{r}84 \\
1,269 \\
1,585 \\
230 \\
(1,720) \\
(879) \\
(1,908) \\
1,671 \\
2,317 \\
5,648 \\
596 \\
819 \\
53 \\
101 \\
(31) \\
(351) \\
(493) \\
4,540 \\
(35)\end{array}$ & $\begin{array}{r}316 \\
18,531 \\
2,015 \\
170 \\
1,220 \\
1,779 \\
6,908 \\
1,829 \\
1,983 \\
6,152 \\
1,904 \\
5,481 \\
2,385 \\
8,199 \\
531 \\
3,284 \\
2,393 \\
14,760 \\
435\end{array}$ \\
\hline
\end{tabular}


TABLE IV

POPULATION CHANGE IN THE PACIFIC STATES, 1960-1975 (continued)

\begin{tabular}{|c|c|c|c|c|c|c|c|}
\hline COUNTY & 1960 & 1965 & 1970 & 1975 & $\begin{array}{l}\text { CHANGE } \\
1960-1965\end{array}$ & $\begin{array}{l}\text { CHANGE } \\
1965-1970\end{array}$ & $\begin{array}{l}\text { CHANGE } \\
1970-1975\end{array}$ \\
\hline \multicolumn{8}{|c|}{ CALIFORNIA, CONTIKUED } \\
\hline \multicolumn{8}{|c|}{ NOKADJACENT } \\
\hline $\begin{array}{l}\text { SISKIYOU } \\
\text { TEHAMA } \\
\text { TRINITY } \\
\text { TULARE } \\
\text { TUOLUHAE } \\
\text { YUBA }\end{array}$ & $\begin{array}{r}32,885 \\
25,305 \\
9,706 \\
168,403 \\
14,404 \\
33,859\end{array}$ & $\begin{array}{r}33,600 \\
28,600 \\
7,700 \\
183,200 \\
17,900 \\
42,500\end{array}$ & $\begin{array}{r}33,225 \\
29,517 \\
7,615 \\
188,322 \\
22,169 \\
44,736\end{array}$ & $\begin{array}{r}35,400 \\
32,100 \\
9,600 \\
209,400 \\
26,000 \\
45,200\end{array}$ & $\begin{array}{c}715 \\
3,295 \\
(2,006) \\
14,797 \\
3,496 \\
8,641\end{array}$ & $\begin{array}{c}(375) \\
917 \\
(85) \\
5,122 \\
4,269 \\
2,236\end{array}$ & $\begin{array}{r}2,175 \\
2,583 \\
1,985 \\
21,078 \\
3,831 \\
464\end{array}$ \\
\hline TOTAL & 798,729 & 880,729 & 906,309 & $1,018,700$ & 82,000 & 25,580 & 112,391 \\
\hline \multicolumn{8}{|l|}{ OREGON } \\
\hline \multicolumn{8}{|c|}{ METRO > 500,000 } \\
\hline $\begin{array}{l}\text { CLACKAMAS } \\
\text { MULL THOMAH } \\
\text { WASHINGTON }\end{array}$ & $\begin{array}{r}113,038 \\
522,813 \\
92,237\end{array}$ & $\begin{array}{l}134,000 \\
555,000 \\
122,000\end{array}$ & $\begin{array}{r}166,088 \\
554,668 \\
157,920\end{array}$ & $\begin{array}{r}206,602 \\
552,363 \\
192,904\end{array}$ & $\begin{array}{r}20,962 \\
32,187 \\
29,763 \\
-\end{array}$ & $\begin{array}{c}32,088 \\
(332) \\
35,920\end{array}$ & $\begin{array}{l}40,514 \\
(2,305) \\
34,984\end{array}$ \\
\hline TOTAL & 728,088 & 811,000 & 878,676 & 951.869 & 82,912 & 67,676 & 73,193 \\
\hline \multicolumn{8}{|c|}{ METRO $<500,000$} \\
\hline $\begin{array}{l}\text { LANE } \\
\text { MARIOH } \\
\text { POLK }\end{array}$ & $\begin{array}{r}162,890 \\
120,888 \\
26,523 \\
-\quad .8\end{array}$ & $\begin{array}{r}198,000 \\
145,000 \\
34,200\end{array}$ & $\begin{array}{r}215,401 \\
151,309 \\
35,349\end{array}$ & $\begin{array}{r}241,488 \\
171,519 \\
41,015\end{array}$ & $\begin{array}{r}35,110 \\
24,112 \\
7,677\end{array}$ & $\begin{array}{r}17,401 \\
6,309 \\
1,149\end{array}$ & $\begin{array}{r}26,087 \\
20,210 \\
5,666\end{array}$ \\
\hline TOTAL & 310,301 & 377,200 & 402,059 & 454,022 & 66,899 & 24,859 & 51,963 \\
\hline \multicolumn{8}{|l|}{ AD JACENT } \\
\hline $\begin{array}{l}\text { COLUMBIA } \\
\text { HOOO RIVER } \\
\text { TILLAMOOK } \\
\text { WASCO } \\
\text { YAMHILL }\end{array}$ & $\begin{array}{l}22,379 \\
13,395 \\
18,955 \\
20,205 \\
32,478\end{array}$ & $\begin{array}{l}24,300 \\
14,200 \\
16,100 \\
23,300 \\
39,900\end{array}$ & $\begin{array}{l}28,970 \\
13,187 \\
18,034 \\
20,133 \\
40,213\end{array}$ & $\begin{array}{l}31,992 \\
14,675 \\
18,397 \\
20,336 \\
46,139\end{array}$ & $\begin{array}{c}1,921 \\
805 \\
(2,855) \\
3,095 \\
7,422\end{array}$ & $\begin{array}{c}4.670 \\
(1,013) \\
1,934 \\
(3,167) \\
313\end{array}$ & $\begin{array}{r}3,022 \\
1,488 \\
363 \\
203 \\
5,926\end{array}$ \\
\hline TOTAL & 107,412 & 117,800 & 120,537 & 131,539 & 10,388 & 2,737 & 11,002 \\
\hline
\end{tabular}


TABLE IV

POPULATION CHANGE IN THE PACIFIC STATES, 1960-1975 (continued)

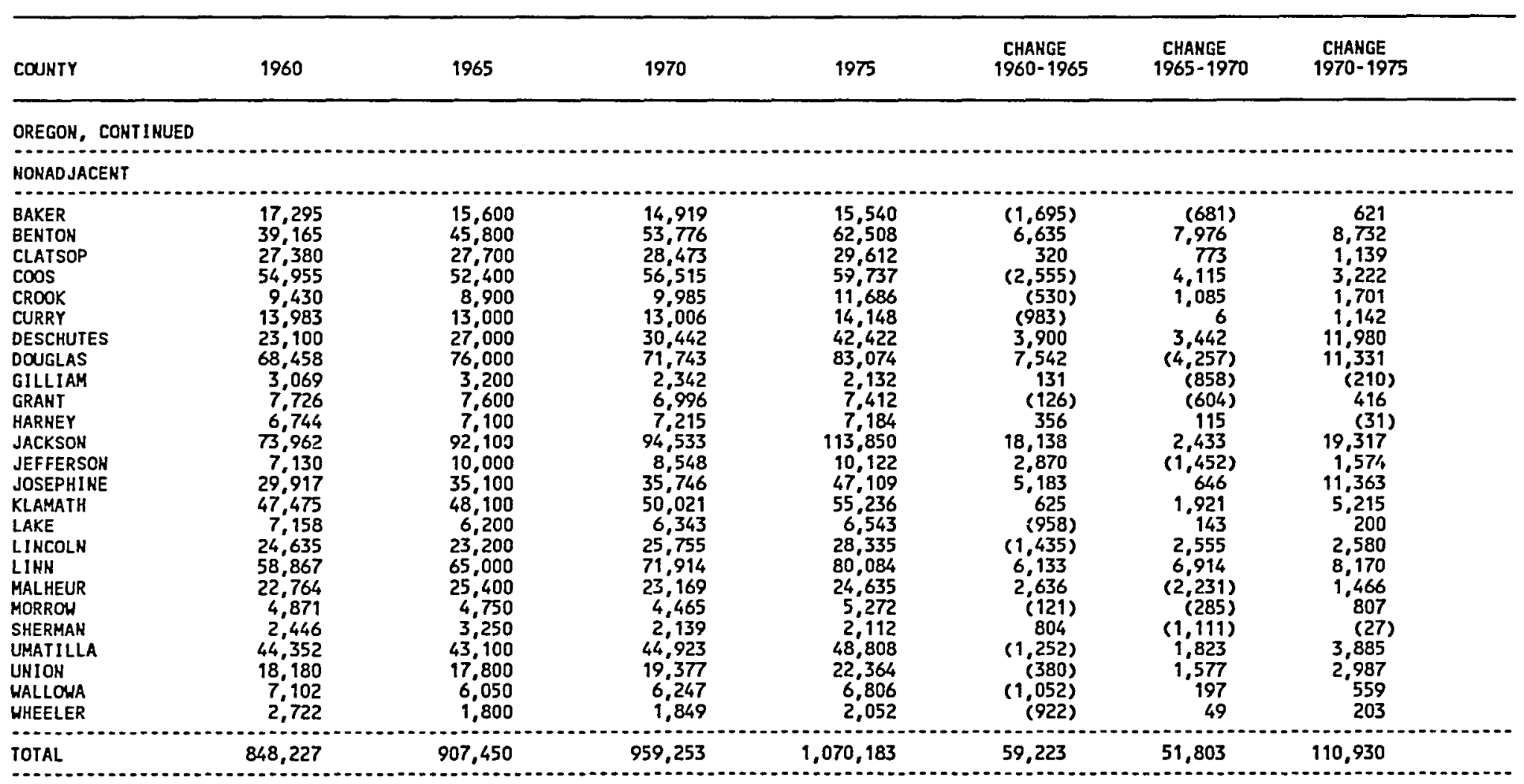


TABLE IV

POPULATION CHANGE IN THE PACIFIC STATES, 1960-1975 (continued)

\begin{tabular}{|c|c|c|c|c|c|c|c|}
\hline COUNTY & 1960 & 1965 & 1970 & 1975 & $\begin{array}{l}\text { CHANGE } \\
1960-1965\end{array}$ & $\begin{array}{l}\text { CHANGE } \\
1965-1970\end{array}$ & $\begin{array}{l}\text { C.HANGE } \\
1970-1975\end{array}$ \\
\hline \multicolumn{8}{|l|}{ WASHIKGTOH } \\
\hline \multicolumn{8}{|c|}{ METRO > 500,000} \\
\hline $\begin{array}{l}\text { CLARK } \\
\text { KING } \\
\text { SHOHOMISH }\end{array}$ & $\begin{array}{r}93,809 \\
935,014 \\
172,199\end{array}$ & $\begin{array}{r}105,000 \\
1,024,000 \\
212,700\end{array}$ & $\begin{array}{r}128,454 \\
1,159,375 \\
265,236\end{array}$ & $\begin{array}{r}149,000 \\
1,148,000 \\
268,000\end{array}$ & $\begin{array}{l}11,191 \\
88,986 \\
40,501\end{array}$ & $\begin{array}{r}23,454 \\
135,375 \\
52,536\end{array}$ & $\begin{array}{c}20,546 \\
(11,375) \\
2,764\end{array}$ \\
\hline TOTAL & $1,201,022$ & $1,341,700$ & $1,553,065$ & $1,565,000$ & 140,678 & 211,365 & 11,935 \\
\hline \multicolumn{8}{|c|}{ METRO $<500,000$} \\
\hline $\begin{array}{l}\text { PIERCE } \\
\text { SPOKANE } \\
\text { YAKIMA }\end{array}$ & $\begin{array}{r}321,590 \\
278,333 \\
145,112 \\
\end{array}$ & $\begin{array}{l}358,600 \\
277,200 \\
143,400\end{array}$ & $\begin{array}{l}411,027 \\
287,487 \\
145,212\end{array}$ & $\begin{array}{l}413,500 \\
298,000 \\
147,600\end{array}$ & $\begin{array}{l}37,010 \\
(1,133) \\
(1,712)\end{array}$ & $\begin{array}{r}52,427 \\
10,287 \\
1,812\end{array}$ & $\begin{array}{r}2,473 \\
10,513 \\
2,388\end{array}$ \\
\hline TOTAL & 745,035 & 779,200 & 843,726 & 859,100 & 34.165 & 64,526 & 15,374 \\
\hline \multicolumn{8}{|l|}{ AD JACENT } \\
\hline $\begin{array}{l}\text { CHELAH } \\
\text { ISLAND } \\
\text { KITSAP } \\
\text { KITIITAS } \\
\text { SKAGIT }\end{array}$ & $\begin{array}{l}40,744 \\
19,638 \\
84,176 \\
20,467 \\
51,350\end{array}$ & $\begin{array}{l}39,800 \\
22,400 \\
89,800 \\
22,400 \\
50,900 \\
\end{array}$ & $\begin{array}{r}41,355 \\
27,011 \\
101,732 \\
25,039 \\
52,381\end{array}$ & $\begin{array}{r}40,900 \\
30,000 \\
116,224 \\
25,300 \\
53,400\end{array}$ & $\begin{array}{c}(944) \\
2,762 \\
5,624 \\
1,933 \\
(450) \\
.\end{array}$ & $\begin{array}{r}1,555 \\
4,611 \\
11,932 \\
2,639 \\
1,481 \\
\ldots . . .\end{array}$ & $\begin{array}{r}(455) \\
2,989 \\
14,492 \\
261 \\
1,019\end{array}$ \\
\hline $\begin{array}{l}\text { TOTAL } \\
\text { TO.... }\end{array}$ & 216,375 & 225,300 & 247,518 & 265,824 & 8,925 & 22,218 & 18,306 \\
\hline \multicolumn{8}{|c|}{ NONAD JACENT } \\
\hline $\begin{array}{l}\text { ADAMS } \\
\text { ASOTIH } \\
\text { BENTON } \\
\text { CLALLAM } \\
\text { COLUMBIA } \\
\text { COWLITZ } \\
\text { DOUGLAS }\end{array}$ & $\begin{array}{r}9,929 \\
12,909 \\
62,070 \\
30,022 \\
4,569 \\
57,801 \\
14,890\end{array}$ & $\begin{array}{r}10,400 \\
12,900 \\
62,500 \\
31,900 \\
4,500 \\
62,500 \\
15,300\end{array}$ & $\begin{array}{r}12,014 \\
13,799 \\
67,540 \\
34,770 \\
4,439 \\
68,616 \\
16,787\end{array}$ & $\begin{array}{r}12,400 \\
14,800 \\
78,700 \\
37,000 \\
4,500 \\
70,700 \\
18,100\end{array}$ & $\begin{array}{c}471 \\
(9) \\
430 \\
1,878 \\
(69) \\
4.699 \\
410\end{array}$ & $\begin{array}{c}1,614 \\
899 \\
5,040 \\
2,870 \\
(61) \\
6,116 \\
1,487\end{array}$ & $\begin{array}{r}386 \\
1,001 \\
11,160 \\
2,230 \\
61 \\
2,084 \\
1,313\end{array}$ \\
\hline
\end{tabular}


TABLE IV

POPULATION CHANGE IN THE PACIFIC STATES, 1960-1975 (continued)

\begin{tabular}{|c|c|c|c|c|c|c|c|}
\hline COUNTY & 1960 & 1965 & 1970 & 1975 & $\begin{array}{c}\text { CHANGE } \\
1960-1965\end{array}$ & $\begin{array}{l}\text { CHANGE } \\
1965-1970\end{array}$ & $\begin{array}{l}\text { CHANGE } \\
1970-1973\end{array}$ \\
\hline \multicolumn{8}{|c|}{ WASHINGTON, CONTINUED } \\
\hline \multicolumn{8}{|l|}{ KONAD JACENT } \\
\hline $\begin{array}{l}\text { FERRY } \\
\text { FRANKLIH } \\
\text { GARFIELD } \\
\text { GRANT } \\
\text { GRAYS HARBOR } \\
\text { JEFFERSON } \\
\text { KLICKITAT } \\
\text { LEHIS } \\
\text { LINCOLN } \\
\text { MASOH } \\
\text { OKAHOGAH } \\
\text { PACIFIC } \\
\text { PEHD OREILLE } \\
\text { SAH JUAH } \\
\text { SKAMANIIA } \\
\text { STEVENS } \\
\text { THURSTON } \\
\text { WAHKIAKUW } \\
\text { WALLA WALLA } \\
\text { WHATCOH } \\
\text { WHITMAN }\end{array}$ & $\begin{array}{r}3,889 \\
23,342 \\
2,976 \\
46,477 \\
54,465 \\
9,639 \\
13,455 \\
41,858 \\
10,919 \\
16,251 \\
6,914 \\
25,520 \\
14,674 \\
2,872 \\
5,, 207 \\
17,884 \\
55,049 \\
3,426 \\
42,195 \\
70,317 \\
31,263\end{array}$ & $\begin{array}{r}3,900 \\
23,800 \\
2,800 \\
44,500 \\
56,400 \\
9,800 \\
12,900 \\
42,900 \\
10,100 \\
17,800 \\
25,100 \\
14,700 \\
6,100 \\
3,100 \\
5,500 \\
17,500 \\
64,400 \\
3,400 \\
41,400 \\
75,900 \\
34,000\end{array}$ & $\begin{array}{r}3,655 \\
25,816 \\
2,919 \\
41,881 \\
59,553 \\
10,661 \\
12,138 \\
45,467 \\
9,572 \\
20,918 \\
25,867 \\
15,796 \\
6,025 \\
3,856 \\
5,845 \\
17,405 \\
76,894 \\
3,592 \\
42,176 \\
85,000 \\
37,900\end{array}$ & $\begin{array}{r}4,200 \\
26,700 \\
2,800 \\
42,700 \\
60,200 \\
11,100 \\
13,000 \\
47,100 \\
9,300 \\
22,200 \\
26,500 \\
15,900 \\
6,500 \\
4,500 \\
5,900 \\
19,000 \\
85,900 \\
3,500 \\
42,200 \\
86,200 \\
38,700\end{array}$ & $\begin{array}{c}11 \\
458 \\
(176) \\
(1,977) \\
1,935 \\
161 \\
(555) \\
1,042 \\
(819) \\
1,549 \\
18,186 \\
(10,820) \\
(8,574) \\
228 \\
293 \\
(384) \\
9,351 \\
(26) \\
(795) \\
4,783 \\
2,737\end{array}$ & $\begin{array}{c}(245) \\
2,016 \\
111 \\
(2,619) \\
3,153 \\
861 \\
(762) \\
2,567 \\
(528) \\
3,118 \\
767 \\
1,096 \\
(75) \\
756 \\
345 \\
(95) \\
12,494 \\
192 \\
776 \\
9,900 \\
3,900\end{array}$ & $\begin{array}{c}545 \\
884 \\
(111) \\
819 \\
647 \\
439 \\
862 \\
1,633 \\
(272) \\
1,282 \\
633 \\
104 \\
475 \\
644 \\
55 \\
1,595 \\
9,006 \\
(92) \\
24 \\
1,200 \\
800\end{array}$ \\
\hline TOTAL & 465,441 & 473,900 & 502,081 & 528,900 & 8,459 & 28,181 & 26,819 \\
\hline
\end{tabular}

Hote: Parentheses indicate numbers.
Source: U.S. Census (1960, 1970a), Cal i fornia State Census (1965, 1975), Center for Population (1965, 1975), Labor Market (1965, 1975). 
counties of the Seattle metropolitan statistical area (King county) gained population. However, the suburban counties' net migration gain is much greater than the core county's net migration gain.

The pattern of growth in the Pacific states in the 1970 s is in contrast to previous periods. Table IV shows that between 1960 to 1970 several of the nonadjacent nonmetropolitan counties experienced negative population growth. Adjacent counties in oregon and washington experienced population losses in the 1960s. However, the majority of adjacent counties in California experienced population gains. All the smaller and larger metropolitan counties, except for San Francisco county, gained population in the $1960 \mathrm{~s}$.

The pattern of labor force movement is very similar to the pattern of general population movement in the three Pacific states. Table $\mathrm{V}$ shows that the highest percentage increase of net civilian labor force migration between 1960 and 1970 occurred in metropolitan counties with populations greater than 500,000, whereas net losses of labor migration occurred in the majority of metropolitan counties with populations less than 500,000 and nonmetropolitan counties. 
TABLE V

LABOR MIGRANT FLOWS, 1965-1975

\begin{tabular}{|c|c|c|c|c|c|c|c|c|c|}
\hline \multicolumn{6}{|c|}{ MUMBER OF LABOR HIGRANTS } & \multicolumn{3}{|c|}{ DIFFERENCE BETHEEN IN } & \multirow{2}{*}{$\begin{array}{l}\text { AND OUT } \\
\text { NET } \\
\text { MIGRATION } \\
1975\end{array}$} \\
\hline COUNTY & $\begin{array}{c}\text { IN- } \\
\text { MIGRANTS } \\
1965\end{array}$ & $\begin{array}{c}\text { OUT- } \\
\text { MIGRANTS } \\
1965\end{array}$ & $\begin{array}{c}\text { IN- } \\
\text { MIGRANTS } \\
1970\end{array}$ & $\begin{array}{l}\text { QUT- } \\
\text { MIGRANTS } \\
1970\end{array}$ & $\begin{array}{c}\text { IN- } \\
\text { MIGRANTS } \\
1975\end{array}$ & $\begin{array}{l}\text { OUT- } \\
\text { MIGRAHTS } \\
1975\end{array}$ & $\begin{array}{c}\text { NET } \\
\text { MIGRATION } \\
1965\end{array}$ & $\begin{array}{l}\text { NET } \\
\text { MIGRATION } \\
1970\end{array}$ & \\
\hline \multicolumn{10}{|l|}{ CALIFORNIA } \\
\hline \multicolumn{10}{|l|}{ METRO > 500,000} \\
\hline $\begin{array}{l}\text { ALAMEDA } \\
\text { CONIRA COSTA } \\
\text { LOS ANGELES } \\
\text { MARIN } \\
\text { ORANGE } \\
\text { PLACER } \\
\text { RIVERSIDE } \\
\text { SACRAMENTO } \\
\text { SAH BERNARDINO } \\
\text { SAN DIEGO } \\
\text { SAN FRANCISCO } \\
\text { SAN MATEO } \\
\text { SANTA CLARA } \\
\text { YOLO }\end{array}$ & $\begin{array}{r}385 \\
172 \\
1,546 \\
93 \\
539 \\
48 \\
140 \\
345 \\
205 \\
180 \\
531 \\
296 \\
398 \\
35\end{array}$ & $\begin{array}{r}487 \\
145 \\
1,785 \\
65 \\
293 \\
18 \\
114 \\
190 \\
187 \\
349 \\
753 \\
284 \\
411 \\
33\end{array}$ & $\begin{array}{r}581 \\
232 \\
1,738 \\
82 \\
630 \\
37 \\
189 \\
403 \\
294 \\
330 \\
733 \\
366 \\
510 \\
35\end{array}$ & $\begin{array}{r}474 \\
179 \\
2,074 \\
90 \\
481 \\
50 \\
168 \\
304 \\
246 \\
269 \\
742 \\
297 \\
350 \\
45\end{array}$ & $\begin{array}{r}480 \\
198 \\
1,470 \\
96 \\
831 \\
43 \\
208 \\
367 \\
267 \\
382 \\
609 \\
357 \\
580 \\
31\end{array}$ & $\begin{array}{r}542 \\
226 \\
2,317 \\
70 \\
566 \\
38 \\
180 \\
269 \\
286 \\
302 \\
749 \\
330 \\
441 \\
34\end{array}$ & $\begin{array}{l}102 \\
(27) \\
239 \\
(28) \\
(246) \\
(30) \\
(26) \\
(155) \\
(18) \\
169 \\
222 \\
(12) \\
13 \\
(2)\end{array}$ & $\begin{array}{c}94 \\
87 \\
(47) \\
17 \\
337 \\
19 \\
75 \\
213 \\
107 \\
(19) \\
(20) \\
82 \\
99 \\
2\end{array}$ & $\begin{array}{c}(107) \\
(53) \\
336 \\
8 \\
(149) \\
13 \\
(21) \\
(99) \\
(48) \\
(61) \\
9 \\
(69) \\
(160) \\
10\end{array}$ \\
\hline TOTAL & 4,913 & 5,114 & 6,160 & 5,769 & 5,919 & 6,350 & 201 & 1,046 & (391) \\
\hline \multicolumn{10}{|l|}{ METRO $<500,000$} \\
\hline $\begin{array}{l}\text { FRESNO } \\
\text { MONTEREY } \\
\text { NAPA } \\
\text { SAN JOAQUIN } \\
\text { SANTA BARBARA } \\
\text { SANTA CRUZ } \\
\text { SOLANO } \\
\text { SONOMA } \\
\text { STANISLAUS } \\
\text { VENTURA }\end{array}$ & $\begin{array}{r}100 \\
80 \\
21 \\
72 \\
126 \\
39 \\
36 \\
65 \\
56 \\
116\end{array}$ & $\begin{array}{r}123 \\
56 \\
12 \\
76 \\
81 \\
38 \\
42 \\
45 \\
38 \\
58\end{array}$ & $\begin{array}{r}119 \\
82 \\
21 \\
108 \\
96 \\
30 \\
47 \\
60 \\
77 \\
105\end{array}$ & $\begin{array}{r}140 \\
66 \\
29 \\
78 \\
104 \\
58 \\
45 \\
62 \\
74 \\
109\end{array}$ & $\begin{array}{r}138 \\
85 \\
29 \\
102 \\
104 \\
55 \\
49 \\
73 \\
58 \\
140\end{array}$ & $\begin{array}{r}117 \\
61 \\
17 \\
93 \\
100 \\
44 \\
45 \\
61 \\
70 \\
88\end{array}$ & $\begin{array}{l}23 \\
(24) \\
(12) \\
4 \\
(45) \\
(1) \\
6 \\
(20) \\
(18) \\
(58)\end{array}$ & $\begin{array}{l}(4) \\
26 \\
9 \\
32 \\
15 \\
(8) \\
5 \\
15 \\
39 \\
47\end{array}$ & $\begin{array}{c}21 \\
(16) \\
8 \\
(30) \\
8 \\
28 \\
(2) \\
2 \\
(3) \\
4\end{array}$ \\
\hline TOTAL & 7114 & 569 & 745 & 765 & 833 & 696 & $(145)$ & 176 & 20 \\
\hline \multicolumn{10}{|l|}{ ADJACENT } \\
\hline $\begin{array}{l}\text { AMADCR } \\
\text { EL DORADO } \\
\text { IMPERIAL } \\
\text { KERH } \\
\text { MERCED } \\
\text { NEVADA } \\
\text { SAN BENITO } \\
\text { SAN LUIS OBISPO } \\
\text { SUTIER }\end{array}$ & $\begin{array}{l}12 \\
17 \\
20 \\
85 \\
21 \\
10 \\
11 \\
25 \\
18\end{array}$ & $\begin{array}{l}26 \\
15 \\
26 \\
88 \\
29 \\
15 \\
2 \\
42 \\
18\end{array}$ & $\begin{array}{r}3 \\
15 \\
23 \\
142 \\
16 \\
11 \\
8 \\
33 \\
12\end{array}$ & $\begin{array}{r}10 \\
23 \\
38 \\
146 \\
47 \\
11 \\
12 \\
30 \\
21\end{array}$ & $\begin{array}{r}4 \\
14 \\
22 \\
105 \\
30 \\
16 \\
6 \\
47 \\
13\end{array}$ & $\begin{array}{r}1 \\
5 \\
28 \\
123 \\
23 \\
0 \\
6 \\
36 \\
36 \\
14\end{array}$ & $\begin{array}{c}14 \\
(2) \\
6 \\
3 \\
8 \\
5 \\
(9) \\
17 \\
0\end{array}$ & $\begin{array}{c}(23) \\
0 \\
(3) \\
54 \\
(13) \\
(4) \\
6 \\
(9) \\
(6)\end{array}$ & $\begin{array}{r}7 \\
8 \\
15 \\
4 \\
31 \\
0 \\
4 \\
(3) \\
9\end{array}$ \\
\hline TOTAL & 219 & 261 & 263 & 338 & 257 & 242 & 42 & 2 & 75 \\
\hline
\end{tabular}


TABLE V

LABOR MIGRANT FLOWS, 1965-1975 (continued)

\begin{tabular}{|c|c|c|c|c|c|c|c|c|c|}
\hline COUNTY & $\begin{array}{l}\text { NUABEF } \\
\text { IN- } \\
\text { MIGRANTS } \\
1965\end{array}$ & $\begin{array}{l}\text { R OF LABOF } \\
\text { OUT- } \\
\text { MIGRANTS } \\
1965\end{array}$ & $\begin{array}{l}\text { R HIGRANTS } \\
\text { IH- } \\
\text { MIGRANTS } \\
1970\end{array}$ & $\begin{array}{l}\text { OUT - } \\
\text { MIGRANTS } \\
1970\end{array}$ & $\begin{array}{l}\text { IN- } \\
\text { MIGRANTS } \\
1975\end{array}$ & $\begin{array}{l}\text { CUT- } \\
\text { AIGRANTS } \\
1975\end{array}$ & $\begin{array}{l}\text { FEREHCE BE } \\
\text { MIGRAT IOH } \\
1965\end{array}$ & $\begin{array}{c}\text { ETHEEN IN A } \\
\text { NET } \\
\text { MIGRATION } \\
1970\end{array}$ & $\begin{array}{l}\text { AND OUT } \\
\text { NET } \\
\text { MIGRATION } \\
1975\end{array}$ \\
\hline \multicolumn{10}{|c|}{$\begin{array}{l}\text { CALIFORHIA, } \\
\text { NOHADJACENT }\end{array}$} \\
\hline $\begin{array}{l}\text { ALPIHE } \\
\text { BUTTE } \\
\text { CALVERAS } \\
\text { COLUSA } \\
\text { DEL NORTE } \\
\text { GLENN } \\
\text { HUMBOLDT } \\
\text { IHYO } \\
\text { KINGS } \\
\text { LAKE } \\
\text { LASSEH } \\
\text { MADERA } \\
\text { MARIPOSA } \\
\text { MENDOCINO } \\
\text { MOOOC } \\
\text { HONO } \\
\text { PLUMAS } \\
\text { SHASTA } \\
\text { SIERRA } \\
\text { SISKIYOU } \\
\text { TEHAMA } \\
\text { TRINITY } \\
\text { TULARE } \\
\text { TUOLUYHE } \\
\text { YUBA }\end{array}$ & $\begin{array}{r}6 \\
55 \\
6 \\
7 \\
20 \\
11 \\
34 \\
5 \\
19 \\
5 \\
5 \\
13 \\
8 \\
16 \\
8 \\
9 \\
10 \\
39 \\
5 \\
13 \\
18 \\
3 \\
44 \\
15 \\
32\end{array}$ & $\begin{array}{r}26 \\
37 \\
23 \\
9 \\
18 \\
7 \\
74 \\
3 \\
19 \\
6 \\
5 \\
14 \\
3 \\
20 \\
7 \\
2 \\
9 \\
26 \\
2 \\
16 \\
15 \\
5 \\
65 \\
3 \\
30\end{array}$ & $\begin{array}{r}0 \\
38 \\
3 \\
4 \\
9 \\
6 \\
42 \\
12 \\
8 \\
3 \\
8 \\
10 \\
2 \\
12 \\
1 \\
1 \\
3 \\
29 \\
0 \\
10 \\
16 \\
2 \\
51 \\
8 \\
21\end{array}$ & $\begin{array}{r}6 \\
50 \\
9 \\
7 \\
12 \\
16 \\
48 \\
7 \\
20 \\
4 \\
3 \\
20 \\
7 \\
27 \\
10 \\
11 \\
13 \\
54 \\
5 \\
17 \\
15 \\
2 \\
51 \\
10 \\
21\end{array}$ & $\begin{array}{r}1 \\
40 \\
8 \\
9 \\
13 \\
8 \\
36 \\
9 \\
11 \\
3 \\
8 \\
18 \\
3 \\
15 \\
4 \\
12 \\
2 \\
25 \\
0 \\
9 \\
11 \\
2 \\
57 \\
12 \\
18\end{array}$ & $\begin{array}{r}0 \\
45 \\
6 \\
5 \\
6 \\
7 \\
50 \\
2 \\
12 \\
5 \\
4 \\
14 \\
2 \\
10 \\
1 \\
3 \\
5 \\
28 \\
1 \\
7 \\
14 \\
1 \\
55 \\
5 \\
13\end{array}$ & $\begin{array}{c}20 \\
(18) \\
17 \\
2 \\
(2) \\
(4) \\
40 \\
(2) \\
0 \\
1 \\
0 \\
1 \\
(5) \\
4 \\
(1) \\
(7) \\
(1) \\
(13) \\
(3) \\
3 \\
(3) \\
2 \\
21 \\
(12) \\
(2)\end{array}$ & $\begin{array}{c}(26) \\
1 \\
(20) \\
(5) \\
(9) \\
(1) \\
(32) \\
9 \\
(11) \\
(3) \\
3 \\
(4) \\
(1) \\
(8) \\
(6) \\
(1) \\
(6) \\
3 \\
(2) \\
(6) \\
1 \\
(3) \\
(14) \\
5 \\
(9)\end{array}$ & $\begin{array}{r}6 \\
12 \\
6 \\
3 \\
3 \\
10 \\
6 \\
(5) \\
12 \\
1 \\
(5) \\
10 \\
5 \\
15 \\
9 \\
10 \\
10 \\
25 \\
5 \\
7 \\
(1) \\
0 \\
0 \\
2 \\
0\end{array}$ \\
\hline TOTAL & 406 & 444 & 299 & 445 & 334 & 301 & 38 & $(145)$ & 146 \\
\hline \multicolumn{10}{|l|}{ OREGON } \\
\hline \multicolumn{10}{|c|}{ METRO > 500,000 } \\
\hline $\begin{array}{l}\text { CLACKAMAS } \\
\text { MULTNOMAH } \\
\text { WASHINGTON }\end{array}$ & $\begin{array}{r}53 \\
290 \\
66\end{array}$ & $\begin{array}{r}52 \\
306 \\
27\end{array}$ & $\begin{array}{r}69 \\
394 \\
75\end{array}$ & $\begin{array}{r}70 \\
330 \\
52\end{array}$ & $\begin{array}{l}116 \\
418 \\
119\end{array}$ & $\begin{array}{r}48 \\
401 \\
54\end{array}$ & $\begin{array}{c}(1) \\
16 \\
(39)\end{array}$ & $\begin{array}{l}17 \\
88 \\
48\end{array}$ & $\begin{array}{c}1 \\
(64) \\
(23)\end{array}$ \\
\hline TOTAL & 409 & 385 & 538 & 452 & 653 & 503 & $(24)$ & 153 & (86) \\
\hline \multicolumn{10}{|c|}{ HETRO < 500,000 } \\
\hline $\begin{array}{l}\text { LAHE } \\
\text { MARIOH } \\
\text { POLK }\end{array}$ & $\begin{array}{r}109 \\
90 \\
7\end{array}$ & $\begin{array}{l}96 \\
48 \\
16\end{array}$ & $\begin{array}{r}106 \\
85 \\
11\end{array}$ & $\begin{array}{r}129 \\
69 \\
5\end{array}$ & $\begin{array}{r}98 \\
105 \\
6\end{array}$ & $\begin{array}{r}102 \\
72 \\
14\end{array}$ & $\begin{array}{c}(13) \\
(42) \\
9\end{array}$ & $\begin{array}{l}10 \\
37 \\
(5)\end{array}$ & $\begin{array}{c}23 \\
(16) \\
(6)\end{array}$ \\
\hline TOTAL & 206 & 160 & 202 & 203 & 209 & 188 & (46) & 42 & 1 \\
\hline
\end{tabular}


TABLE V

LABOR MIGRANT FLOWS, 1965-1975 (continued)

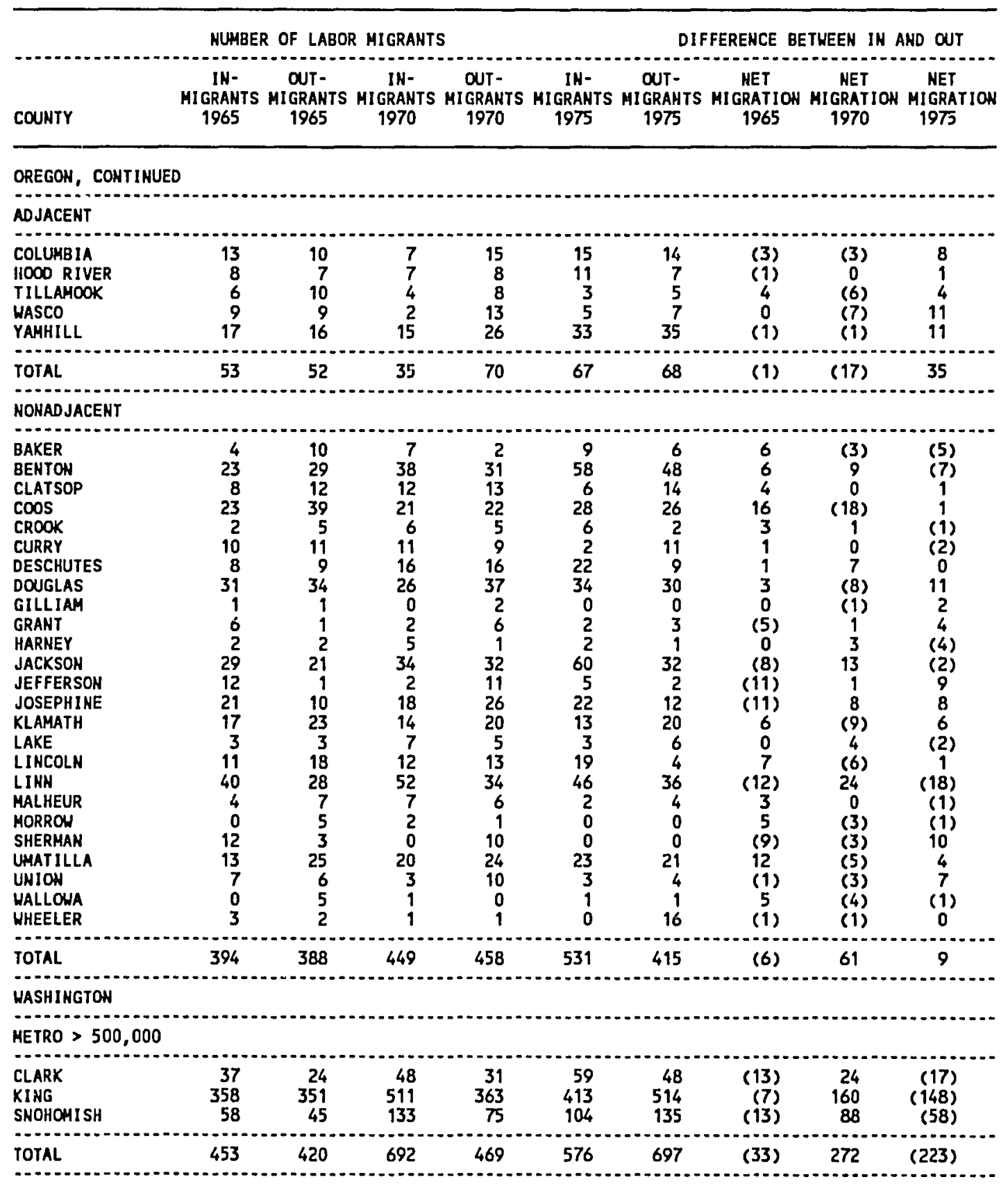


TABLE $\mathrm{V}$

LAABOR MIGRANT FLOWS, 1965-1975

(continued)

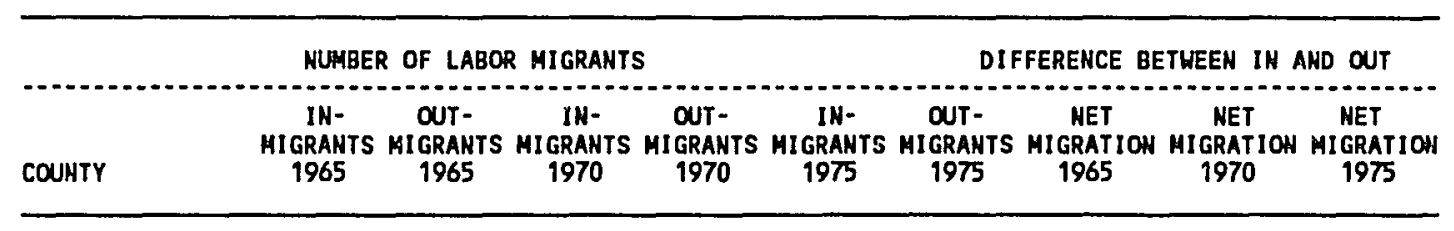

WASHINGTOH, CONTINUED

METRO $<500,000$

\begin{tabular}{|c|c|c|c|c|c|c|c|c|c|}
\hline $\begin{array}{l}\text { PIERCE } \\
\text { SPOKAHE } \\
\text { YAKIMA }\end{array}$ & $\begin{array}{l}87 \\
67 \\
53\end{array}$ & $\begin{array}{r}101 \\
97 \\
60\end{array}$ & $\begin{array}{r}105 \\
78 \\
51\end{array}$ & $\begin{array}{r}104 \\
90 \\
73\end{array}$ & $\begin{array}{r}122 \\
81 \\
93\end{array}$ & $\begin{array}{r}116 \\
87 \\
71\end{array}$ & $\begin{array}{r}14 \\
30 \\
7\end{array}$ & $\begin{array}{c}4 \\
(19) \\
(9)\end{array}$ & $\begin{array}{l}(1) \\
12 \\
22\end{array}$ \\
\hline TOTAL & 207 & 258 & 234 & 267 & 296 & 274 & 51 & $(2 / 4)$ & 33 \\
\hline
\end{tabular}

ADJACENT

\begin{tabular}{|c|c|c|c|c|c|c|c|c|c|}
\hline $\begin{array}{l}\text { CHELAN } \\
\text { ISLAND } \\
\text { KITSAP } \\
\text { KITTITAS } \\
\text { SKAGIT }\end{array}$ & $\begin{array}{r}16 \\
1 \\
20 \\
6 \\
14\end{array}$ & $\begin{array}{r}17 \\
4 \\
26 \\
11 \\
10\end{array}$ & $\begin{array}{r}10 \\
2 \\
24 \\
10 \\
17\end{array}$ & $\begin{array}{r}19 \\
2 \\
26 \\
10 \\
26\end{array}$ & $\begin{array}{r}22 \\
6 \\
29 \\
9 \\
25\end{array}$ & $\begin{array}{r}15 \\
3 \\
17 \\
11 \\
18\end{array}$ & $\begin{array}{c}1 \\
3 \\
6 \\
5 \\
(4)\end{array}$ & $\begin{array}{l}(7) \\
(2) \\
(2) \\
(1) \\
7\end{array}$ & $\begin{array}{l}9 \\
0 \\
2 \\
0 \\
9\end{array}$ \\
\hline
\end{tabular}

\section{NONADJACENT}

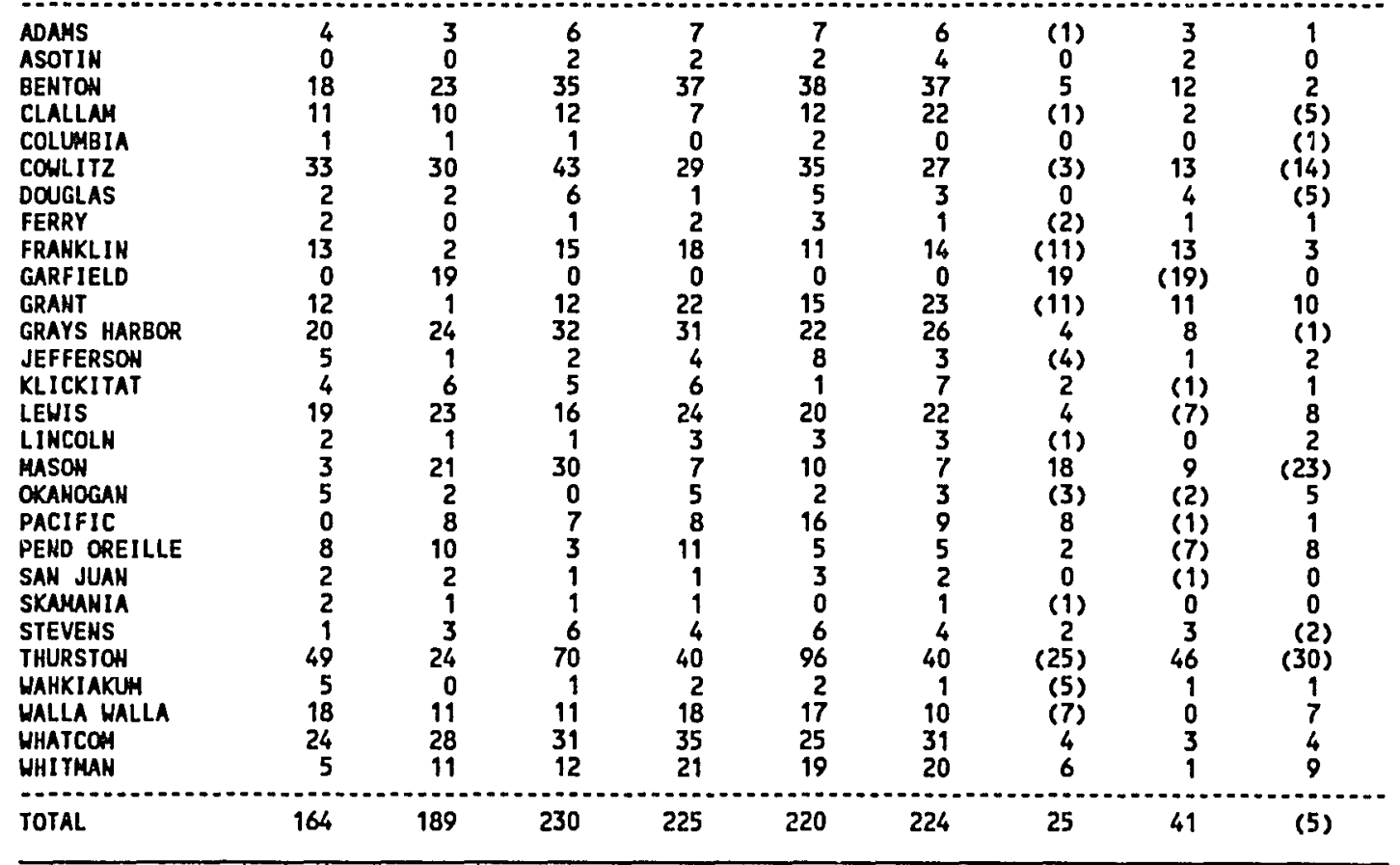

Note: Parenthesis indicate negative numbers.

Source: Calculated from Continuous Work History file One Percent Sample 1965, 1970 and 1975 (U.S. Economic, 1976a). 
By contrast, the majority of nonmetropolitan counties in the Pacific states gained labor migrants between 1970 and 1975. The majority of the metropolitan counties with populations less than 500,000 also gained labor migrants, with the exceptions of Kern and Modesto counties in California, Lane county in oregon, and spokane county in Washington. Similarly, labor migrants shifted from the core counties of the larger metropolitan statistical areas to their suburban periphery counties. More labor migrants moved away from the two largest metropolitan counties in California (Los Angeles and San Francisco) and the largest metropolitan county in oregon (Multnomah) than labor migrants moved to them in the 1970s. However, in Washington, more labor migrants moved to the largest county (king) than moved away from it.

\section{EMPLOYMENT CHANGE IN THE} PACIFIC COAST STATES

This thesis argues that the increased employment growth in the nonmetropolitan counties is not a return to the land movement, rather a result of changes in the employment structure in nonmetropolitan counties. For instance, the total U.S. farm population steadily declined from $23 \%$ in 1940 to $3 \%$ in 1980 (Brewer, 1981). The loss of agrarian employment was offset by manufacturing job gains in nonmetropolitan counties. BY 1970, 25\% of all U.S. manufacturing jobs were located in nonmetropolitan counties. 
Between 1970 and 1978 , nonmetropolitan counties gained an additional 619,000 manufacturing jobs and 3,452,000 service jobs (Beale, 1980).

The above figures hide the diversity of employment opportunities in the nonmetropolitan counties. In 1970, $3.8 \%$ of the nonmetropolitan counties had as high as $30 \%$ of their labor force employed in agriculture. The majority of these counties were located in the Pacific Northwest, the Mississippi Delta, and the Corn Belt. Another 24.9\% of nonmetropolitan counties had between 10 to $19 \%$ of their labor force employed in agriculture (Beale, 1980).

THE SPATIAL CONTEXT OF THE PACIFIC REGION

Within the Pacific states of California, Oregon, and Washington live $13 \%$ of all U.S. inhabitants. About four fifths of the Pacific region's population live in California. Between 1965 and 1975, the population in the Pacific states increased by approximately 7 million. Twenty-two percent of the region's population increase between 1970 and 1975 was a result of an increase of in-migration.

Morrill, Downing, and Leon (1986) and Stevens (1980) hypothesize continued infusion of in-migration to the Pacific states is for noneconomic quality-of-life, reasons rather than economic opportunities. Their survey/results and in-depth interviews reveal that ex-urbanites claim that 
they moved to the nonmetropolitan counties in the Pacific Northwest and northern California for outdoor recreation opportunities and the slow pace of "rural life," rather than economic opportunities.

Before fully investigating the amenities/income tradeoff, it is necessary first to examine the economic structure of the three states. The economic development literature characterizes the economy of the Pacific states as a dual economy dominated by nonroutine technologyintensive sectors (i.e., aerospace, electronics, and instruments) and resource-intensive sectors (i.e., agriculture, natural resources, and food processing). The most salient feature of the local economies in northern California, western oregon, and Washington is the dependency on the wood products industry. The Pacific states have approximately $30 \%$ of the U.S. softwood timber stock and approximately one half of the nation's cut softwood sawtimber (Hibbard, 1989; Morrill, Downing, \& Leon, 1986; Shapira \& Leigh-Preston, 1984).

Yet at the same time the Pacific states are recognized as a well-developed center of industrial innovation with key educational and research institutions (i.e., University of California at Berkeley and Los Angeles; Stanford University in Santa clara county, CA; and University of Washington in Seattle, WA). Knowledge-intensive (nonroutine) production activities are evident across industrial sectors, i.e., 
aerospace and transportation equipment (Seattle, WA) and electronics and scientific instruments (silicon Valley in California). In Oregon, Portland's suburban Washington county is now dubbed the silicon Forest (Hibbard, 1989; Markusen, Hall, \& Glasmeier, 1986; Saxenian, 1985).

The duality of the Pacific state's employment structure is reflected in the above national average employment concentration of the nonroutine and resource-intensive industries in the three states (see Table VI). In 1975, California had above national employment average in several knowledge-intensive sectors, in particular electrical machinery (with a location quotient of 1.66) and instruments (with a location quotient of 1.16) (a location quotient is a statistical technique that measure the degree of concentration of an activity [usually employment] in a given industry that is concentrated in a particular place [Heilbrun, 1981]). At the same time, California still had above average employment in its resource sectors, especially the agricultural related sectors (with a location quotient of 1.75) and petroleum and coal products (with a location quotient of 1.14 ).

The economy in oregon has less employment concentration in the knowledge-intensive sectors than do the economies of California and Washington. Just one oregon knowledge-intensive sector, instruments, is above the national employment average (with a location quotient of 
TABLE VI

EMPLOYMENT CONCENTRATION: LOCATION QUOTIENTS

FOR THE MAJOR INDUSTRIAL SECTORS, 1975

INDUSTRIAL SECTORS

CALIFORNIA OREGON WASHINGTON

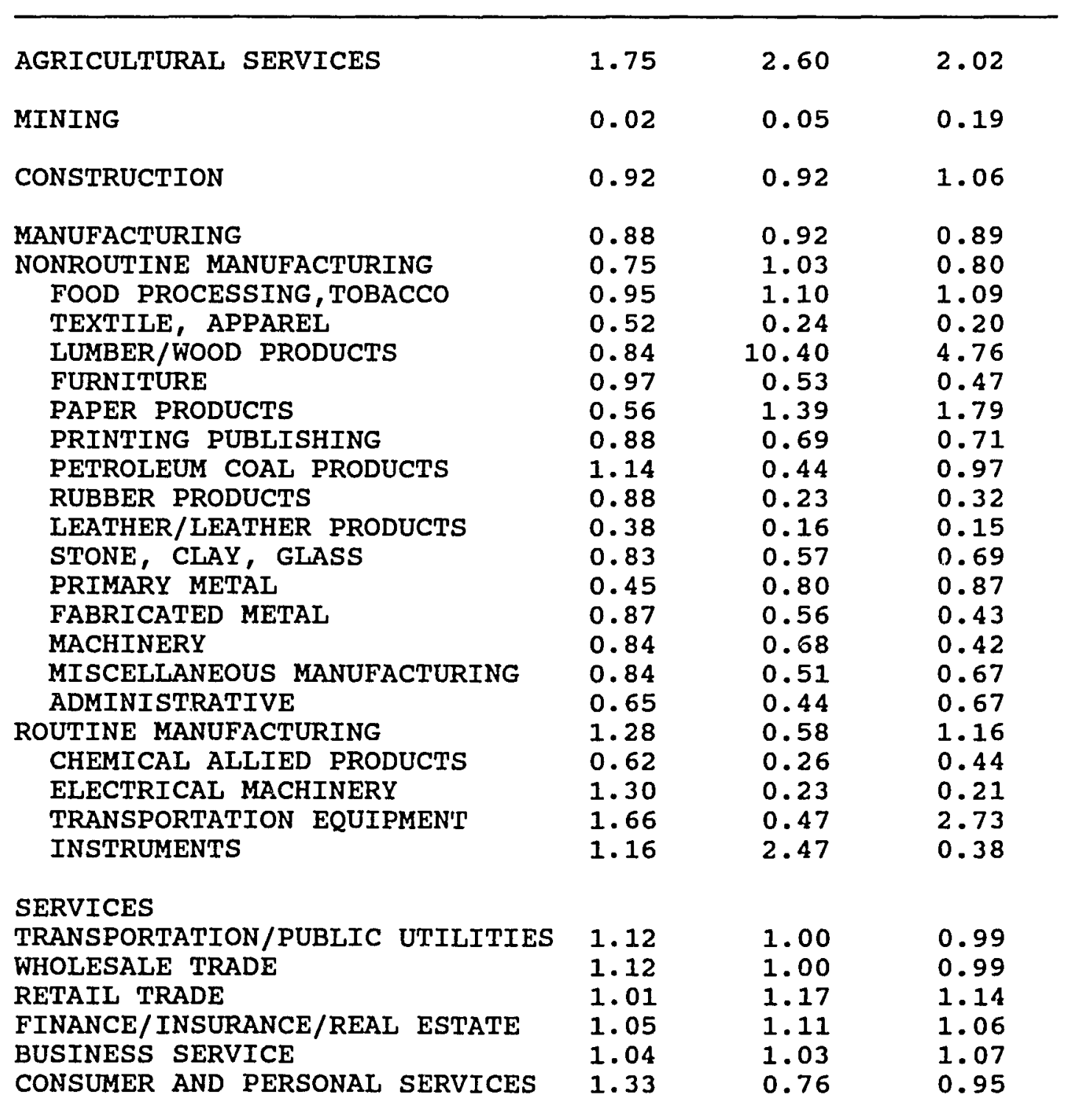

Source: Calculated from U.S. Census (1975). 
2.47). Oregon's resource-intensive sectors continue to dominate the state's economy, especially wood products and agricultural related production. The resource sectors in oregon, which show above national employment averages, are agricultural services (with a location quotient of 2.60), food processing (with a location quotient of 1.10), lumber/wood products (with a location quotient of 10.4), and paper products (with a location quotient of 1.39 ). Washington state has above national employment concentration in one knowledge-intensive sector and several resource-intensive sectors. Transportation equipment shows above the national employment average (with a location quotient of 2.73 ). The resource sectors that show above national employment averages are agricultural services (with location quotient of 2.02 ), food processing (with location quotient of 1.09 ), lumber/wood products (with a location quotient of 4.76 ), and paper products (with a location quotient of 1.79$)$.

Between the years 1970 and 1975, all three states lost manufacturing jobs. California lost .2\% of its manufacturing jobs. Oregon lost about $5.7 \%$ of its manufacturing jobs. Washington lost about . $3 \%$ of its manufacturing jobs (see Tables VII-XI). 
TABLE VII

EMPLOYMENT BY MAJOR INDUSTRIAL SECTORS, 1965

\begin{tabular}{|c|c|c|c|c|}
\hline INDUSTRIAL SECTOR & USA & CALIFORHIA & OREGON & WASHINGTON \\
\hline AGRICULTURAL SERVICES & 143,747 & 20,483 & 2,037 & 3,375 \\
\hline MINING & 596,386 & 35,196 & 1,832 & 2,111 \\
\hline CONSTRUCTION & $2,635,673$ & 314,401 & 30,161 & 42,900 \\
\hline MANUFACTURING & $16,935,412$ & $1,359,818$ & 145,579 & 215,800 \\
\hline ROUTINE MANUFACTURING & $12,540,630$ & 815,548 & 130,131 & 134,216 \\
\hline FOOD PROCESSING, TOBACCO & $1,613,801$ & 138,991 & 14,973 & 21,253 \\
\hline TEXTILE, APPAREL . & $2,136,952$ & 75,474 & 5,150 & 643 \\
\hline LUABER/WOOO PROOUCTS & 565,368 & 46,409 & 68,827 & 42,159 \\
\hline FURNITURE & 380,044 & 32,504 & 2,756 & 2,809 \\
\hline PAPER PROOUCTS & 583,678 & 29,156 & 7,027 & 18,284 \\
\hline PRINTING PUBLISHING & 925,385 & $78,68 !$ & 5,316 & 9,233 \\
\hline PETROLEUM COAL PROOUCTS & 150,581 & 16,441 & 361 & 1,316 \\
\hline RUBBER PROOUCTS & 417,365 & 30,832 & 607 & 634 \\
\hline LEATHER/LEATHER PROOUCTS & 325,985 & 6,019 & 276 & 359 \\
\hline STOHE, CLAY, GLASS & 563,247 & 47,903 & 2,778 & 5,264 \\
\hline PRIMARY HETAL & $1,151,851$ & 47,100 & 5,076 & 11,366 \\
\hline FABRICATED METAL & $1,080,182$ & 91,951 & 5,159 & 6,011 \\
\hline MACHIMERY & $1,527,567$ & 97,821 & 6,914 & 8,818 \\
\hline MISCELLANEOUS MAKUFACTURING & 369,608 & 23,700 & 1,629 & 1,903 \\
\hline ADMINISTRATIVE & 749,016 & 52,566 & 3,282 & 4,164 \\
\hline MOAROUTINE MAHUFACTURING & $4,152,194$ & 435,450 & 15,327 & 77,108 \\
\hline ORDNANCE AND ACCESSORIES & 0 & 0 & 0 & 0 \\
\hline CHEMICAL ALLIED PROOUCTS & 748,293 & 39,884 & 1,731 & 8,702 \\
\hline ELECTRICAL MACHINERY & $1,465,767$ & 171,199 & 5,739 & 2,794 \\
\hline TRANSPORTATION EQUIPHENT & $1,627,597$ & 199,568 & 6,629 & 65,205 \\
\hline IHSTRUAAENTS & 310,537 & 24,799 & 1,228 & 407 \\
\hline \multicolumn{5}{|l|}{ SERVICES } \\
\hline TRAHSPORTATION/PUBLIC UTILITIES & $3,099,079$ & 335,434 & 34,179 & 46,104 \\
\hline HHOLESALE TRADE & $3,324,924$ & 337,376 & 38,370 & 53,647 \\
\hline RETAIL TRADE & $8,576,011$ & 914,960 & 92,253 & 132,016 \\
\hline FIHANCE/IHSURANCE/REAL ESTATE & $2,914,936$ & 318,964 & 26,462 & 41,477 \\
\hline BUSIMESS SERVICE & $1,117,690$ & 165,689 & 8,675 & 13,182 \\
\hline SERVICES & $6,170,564$ & 683,381 & 14,148 & 97,550 \\
\hline TOTAL & $45,683,437$ & $4,512,509$ & 448,427 & 650,512 \\
\hline
\end{tabular}

Source: U.S. Census (1965). 
TABLE VIII

EMPLOYMENT BY MAJOR INDUSTRIAL SECTORS, 1970

\begin{tabular}{|c|c|c|c|c|}
\hline INDUSTRIAL SECTOR & USA & CALIFORNIA & OREGON & HASHINGTON \\
\hline AGRICULTURAL SERVICES & 189,026 & 27,103 & 2,958 & 4,661 \\
\hline MINIHG & 600,715 & 36,621 & 1,387 & 1,992 \\
\hline CONSTRUCTION & $3,197,382$ & 301,086 & 26,902 & 50,348 \\
\hline MAHUFACTURIHG & $19,761,548$ & $1,608,244$ & 162,791 & 245,247 \\
\hline ROUTIHE MANUFACTURIHG & $14,433,949$ & 969,742 & 147,534 & 146,997 \\
\hline FOOO PROCESSING, TOBACCO & $1,666,397$ & 142,871 & 28,406 & 24,350 \\
\hline TEXTILE, APPAREL & $2,324,090$ & 84,184 & 3,242 & 6,103 \\
\hline LUMBER/HOOO PROOUCTS & 554,835 & 44,334 & 61,655 & 38,406 \\
\hline FURHI TURE & 445,756 & 37,911 & 3,173 & 3,111 \\
\hline PAPER PRODUCTS & 668,087 & 34,335 & 8,706 & 18,642 \\
\hline PRINTING PUBLISHIMG & $1,082,353$ & 90,472 & 6,295 & 10,894 \\
\hline PETROLEUH COAL PROOUCTS & 136,170 & 17,048 & 342 & 1,419 \\
\hline RUBBER PROOUCTS & 558,186 & 43,358 & 823 & 1,418 \\
\hline LEATHER/LEATHER PROOUCTS & 304,367 & 6,864 & 201 & 500 \\
\hline STOHE， CLAY， GLASS & 592,150 & 47,985 & 2,628 & 5,761 \\
\hline PRIMARY METAL & $1,268,342$ & 52,741 & 7,700 & 14,288 \\
\hline FABRICATED METAL & $1,353,513$ & 113,847 & 7.064 & 7,461 \\
\hline HACHINERY & $1,996,070$ & 154,476 & 9,907 & 10,141 \\
\hline MISCELLANEOUS MANUFACTURING & 422,329 & 35,173 & 2,013 & 2,687 \\
\hline ADMINISTRATIVE & $1,061,304$ & 64,143 & 5,379 & 1,816 \\
\hline HOHROUTINE MANUFACTURING & $4,984,367$ & 638,382 & 25,122 & 95,200 \\
\hline ORDINAMCE AND ACCESSORIES & 343,232 & 130,367 & 0 & 0 \\
\hline CHEMICAL ALLIED PROOUCTS & 881,275 & 46,217 & 2,649 & 6,086 \\
\hline ELECTRICAL MACHINERY & $1,881,082$ & 210,275 & 9,907 & 5,688 \\
\hline TRANSPORTATIOH EQUIPMEHT & $1,817,492$ & 215,593 & 9,915 & 82,707 \\
\hline INSTRUAENTS & 404,518 & 35,930 & 2,651 & 719 \\
\hline \multicolumn{5}{|l|}{ SERVICES } \\
\hline TRAHSPORTATIOH/PUBLIC UTILITIES & $3,837,876$ & 409,717 & 39,296 & 58,856 \\
\hline WHOLESALE TRADE & $4,035,995$ & 397,559 & 46,286 & 63,409 \\
\hline RETAIL TRADE & $11,071,289$ & $1,140,050$ & 114,393 & 174,848 \\
\hline FIHAHCE/IHSURAMCE/REAL ESTATE & $3,674,899$ & 383,455 & 34,784 & 57,832 \\
\hline BUSIHESS SERVICE & $1,869,097$ & 236,457 & 13,462 & 20,827 \\
\hline COWSUMER AND PERSONAL SERVICES & $8,602,371$ & 917,144 & 87,669 & 139,323 \\
\hline TOTAL & $57,265,292$ & $5,517,039$ & 535,147 & 825,801 \\
\hline
\end{tabular}

Source: U.S. Census (1970b). 
TABLE IX

EMPLOYMENT BY MAJOR INDUSTRIAL SECTORS, 1975

\begin{tabular}{|c|c|c|c|c|}
\hline INDUSTRIAL SECTOR & USA & CALIFORHIA & OREGON & WASHINGTON \\
\hline AGRICULTURAL SERVICES & 195,145 & 33,794 & 5,196 & 5,912 \\
\hline MIHIHG & 717,202 & $1, \sqrt{51}$ & 367 & 2,006 \\
\hline CONSTRUCTION & $3,321,173$ & 302,056 & 31,302 & 52,857 \\
\hline MANUFACTURING & $18,374,397$ & $1,605,211$ & 172,191 & 244,528 \\
\hline ROUTIME MANUFACTURING & $13,856,430$ & $1,032,914$ & 145,488 & 165,358 \\
\hline FOOO PROCESSIHG, TOBACCO & $1,518,563$ & 142,561 & 17,062 & 24,877 \\
\hline TEXTILE, APPAREL & $1,997,809$ & 103,637 & 4,917 & 5,931 \\
\hline LUMBER/WOOO PROOUCTS & 568,166 & 47,201 & 60,420 & 40,540 \\
\hline FURAITURE & 395,184 & 38,066 & 2,147 & 2,767 \\
\hline PAPER PROOUCTS & 585,344 & 32,652 & 8,310 & 15,679 \\
\hline PRINTING PUBLISHING & $1,081,730$ & 93,904 & 7,675 & 11,444 \\
\hline PETROLEUM COAL PROOUCTS & 145,291 & 16,346 & 661 & 2,121 \\
\hline RUBBER PRODUCTS & 587,951 & 51,333 & 1,400 & 2,785 \\
\hline LEATHER/LEATHER PROOUCTS & 225,870 & 8,560 & 375 & 516 \\
\hline STOHE, CLAY, GLASS & 576,648 & 47,309 & 3,372 & 5,979 \\
\hline PRIMARY METAL & $1,156,257$ & 51,476 & 9,448 & 15,038 \\
\hline FABRICATED METAL & $1,400,876$ & 120,475 & 8,051 & 9,085 \\
\hline MACHIHERY & $2,076,434$ & 172,283 & 14,358 & 13,153 \\
\hline MISCELLAMEOUS MANUFACTURING & 405,116 & 33,642 & 2,126 & 4,043 \\
\hline ADMINISTRATIVE & $1,135,191$ & 73,469 & 5,166 & 11,400 \\
\hline NONROUTIHE HANUFACTURING & $4,517,967$ & 574,854 & 26,590 & 78,438 \\
\hline ORDIMAKCE AND ACCESSORIES & & 0 & 0 & 0 \\
\hline CHEMICAL ALLIED PROOUCTS & 839,116 & 51,635 & 2,198 & 5,577 \\
\hline ELECTRICAL MACHINERY & $1,572,884$ & 202,670 & 3,670 & 4,858 \\
\hline TRANSPORTATION EQUIPMENT & $1,588,215$ & 260,808 & 7,628 & 65,086 \\
\hline INSTRUMENTS & $517, \pi 32$ & 59,741 & 13,094 & 2,917 \\
\hline \multicolumn{5}{|l|}{ SERVICES } \\
\hline TRAMSPORTATIOA/PUBLIC UTILITIES & $3,935,326$ & 436,506 & 40,422 & 58,586 \\
\hline WHOLESALE TRADE & $4,332,992$ & 432,858 & 51,937 & 73,880 \\
\hline RETAIL TRADE & $12,270,957$ & $1,281,554$ & 138,824 & 195,873 \\
\hline FINAKCE/INSURANCE/REAL ESTATE & $4,263,362$ & 440,268 & 45,085 & 68,610 \\
\hline BUSIHESS SERVICE & $1,956,452$ & 257,276 & 15,226 & 27,843 \\
\hline COHSUMER ANO PERSOHAL SERVICES & $10,701,111$ & $1,117,807$ & 112,360 & 169,479 \\
\hline TOTAL & $60,564,361$ & $5,999,041$ & 619,473 & 908,305 \\
\hline
\end{tabular}


TABLE X

EMPLOYMENT CHANGE IN PACIFIC STATES, 1965-1970

\begin{tabular}{|c|c|c|c|c|}
\hline INDUSTRIAL SECTOR & USA & CALIFORMIA & OREGOH & WASHINGTOH \\
\hline AGRICULTURAL SERVICES & 45,279 & 6,620 & 921 & 1,286 \\
\hline MINING & 4,329 & 1,425 & $(445)$ & (119) \\
\hline CONSTRUCTIOH & 561,709 & $(13,315)$ & $(3,259)$ & 7,448 \\
\hline MANUFACTURING & $2,826,136$ & 248,426 & 97,212 & 29,447 \\
\hline ROUTINE MANUFACTURING & $1,893,319$ & 154,194 & 17,403 & 12,781 \\
\hline FOOO PROCESSING, TOBACCO & 52,596 & 3,880 & 13,433 & 3,097 \\
\hline TEXTILE, APPAREL & 187,138 & 8,710 & $(1,908)$ & 5,460 \\
\hline LUMBER/WOOO PRODUCTS & $(10,533)$ & $(2,075)$ & $(7,172)$ & $(3,753)$ \\
\hline FURHITURE & 65,712 & 5,407 & 417 & 302 \\
\hline PAPER PROOUCTS & 84,409 & 5,179 & 1,679 & 358 \\
\hline PRINTING PUBLISHIHG & 156,968 & 11,791 & 979 & 1,661 \\
\hline PETROLELM COAL PRODUCTS & $(14,411)$ & 607 & (19) & 103 \\
\hline RUBBER PROOUCTS & 140,821 & 12,526 & 216 & 784 \\
\hline LEATHER/LEATHER PROOUCTS & $(21,618)$ & 845 & (75) & 141 \\
\hline STONE, CLAY, GLASS & 28,903 & 82 & $(150)$ & 497 \\
\hline PRIMARY METAL & 116,491 & 5,641 & 2,624 & 2,922 \\
\hline FABRICATED METAL & 273,331 & 21,896 & 1,905 & 1,450 \\
\hline MACHINERY & 468,503 & 56,655 & 2,993 & 1,323 \\
\hline MISCELLANEOUS MANUFACTURING & 52,721 & 11,473 & 384 & 784 \\
\hline ADMINISTRATIVE & 312,288 & 11,577 & 2,097 & $(2,348)$ \\
\hline NONROUTINE MANUFACTURING & 832,173 & 202,932 & 9,795 & 18,092 \\
\hline ORDIHANCE AND ACCESSORIES & 343,232 & 130,367 & 0 & 0 \\
\hline CHEMICAL ALLIED PROOUCTS & 132,982 & 6,333 & 918 & $(2,616)$ \\
\hline ELECTRICAL MACHINERY & 415,315 & 39,076 & 4,168 & 2,894 \\
\hline TRANSPORTATION EQUIPMENT & 189,895 & 16,025 & 3,286 & 17,502 \\
\hline IHSTRUHENTS & 93,981 & 11,131 & 1,423 & 312 \\
\hline \multicolumn{5}{|l|}{ SERVICES } \\
\hline TRAMSPORTATION/PUBLIC UTILITIES & 738,797 & 74,283 & 5,117 & 12,752 \\
\hline WHOLESALE TRADE & 711,071 & 60,183 & 7,916 & 9,762 \\
\hline RETAIL TRADE & $2,495,278$ & 225,090 & 22,140 & 42,832 \\
\hline FINANCE/INSURAKCE/REAL ESTATE & 759,963 & 64,491 & 8,322 & 16,355 \\
\hline BUSINESS SERVICE & 751,407 & 70,768 & 4,787 & 7,645 \\
\hline CONSUHER AND PERSOHAL SERVICES & $2,431,807$ & 233,763 & 73,521 & 41,773 \\
\hline TOTAL & $11,581,855$ & $1,004,530$ & 86,720 & 175,289 \\
\hline
\end{tabular}

Note: Parentheses indicates negative numbers. Source: U.S. Census (1965, 1970b). 
TABLE XI

EMPLOYMENT CHANGE IN PACIFIC STATES, 1970-1975

\begin{tabular}{|c|c|c|c|c|}
\hline INDUSTRIAL SECTOR & USA & CALIFORHIA & OREGON & HASH IMGTOW \\
\hline AGRICULTURAL SERYICES & 6,119 & 6,691 & 2,238 & 1,251 \\
\hline HINING & 116,487 & $(34,870)$ & $(1,020)$ & 14. \\
\hline CONSTRUCTION & 123,791 & 970 & 4,400 & 2,509 \\
\hline MANUFACTURIHG & $(1,387,151)$ & $(3,033)$ & 9,400 & $(719)$ \\
\hline ROUTINE MANUFACTURIKG & $(577,519)$ & 63,172 & $(2,046)$ & 18,361 \\
\hline FOOO PROCESSING, TOBACCO & $(147,834)$ & (310) & $(11,344)$ & 527 \\
\hline TEXTILE, APPAREL & $(326,281)$ & 19,453 & 1,675 & (172) \\
\hline LUMBER/HOOO PROOUCTS & 13,331 & 2,867 & $(1,235)$ & 2,134 \\
\hline FURNITURE & $(50,572)$ & 155 & $(1,026)$ & (344) \\
\hline PAPER PROOUCTS & $(82,743)$ & $(1,683)$ & (396) & $(2,963)$ \\
\hline PRIHTING PUBLISHING & (623) & 3,432 & 1,380 & 550 \\
\hline PETROLEUM COAL PROOUCTS & 9,121 & $(702)$ & 319 & 702 \\
\hline RUBBER PRODUCTS & 29,765 & 7,975 & 577 & 1,367 \\
\hline LEATHER/LEATHER PROOUCTS & $(78,497)$ & 1,696 & 174 & 16 \\
\hline STONE, CLAY, GLASS & $(15,502)$ & (676) & 744 & 218 \\
\hline PRIMARY HETAL & $(112,085)$ & $(1,265)$ & 1,748 & 750 \\
\hline FABRICATED METAL & 47,363 & 6,628 & 987 & 1,624 \\
\hline MACHIHERY & 80,364 & 17,807 & 4,451 & 3,012 \\
\hline HISCELLANEOUS MANUFACTURING & $(17,213)$ & $(1,531)$ & 113 & 1,356 \\
\hline ADMINISTRATIVE & 73,887 & 9,326 & (213) & 9,584 \\
\hline NONROUTINE MANUFACTURING & $(466,400)$ & $(63,528)$ & 1,468 & $(16,762)$ \\
\hline CHEMICAL ALLIED PROOUCTS & $(42,159)$ & 5,418 & (451) & (509) \\
\hline ELECTRICAL MACHIHERY & $(308,198)$ & $(7,605)$ & $(6,237)$ & $(830)$ \\
\hline TRANSPORTATION EQUIPHENT & $(229,277)$ & 45,215 & $(2,287)$ & $(17,621)$ \\
\hline IHSTRUHENTS & 113,234 & 23,811 & 10,443 & 2,198 \\
\hline \multicolumn{5}{|l|}{ SERVICES } \\
\hline TRAHSPORTATION/PUBLIC UTILITIES & 97,450 & 26,789 & 1,126 & (270) \\
\hline WHOLESALE TRADE & 296,997 & 35,299 & 5,651 & 10,471 \\
\hline RETAIL TRADE & $1,199,668$ & 141,504 & 24,431 & 21,025 \\
\hline FINAKCE/INSURANCE/REAL ESTATE & 588,463 & 56,813 & 10,301 & 10,778 \\
\hline BUSINESS SERVICE & 87,355 & 20,819 & 1,764 & 7,016 \\
\hline CONSUHER AHD PERSONAL SERVICES & $2,098,740$ & 200,663 & 24,691 & 29,856 \\
\hline TOTAL. & $3,299,069$ & 482,002 & 84,326 & 82,504 \\
\hline
\end{tabular}

Note: Parentheses indicate negative numbers. Source: U.S. Census (1970b, 1975). 
A large part of the loss of manufacturing was in the resource-intensive sectors. The resource-intensive sectors in California lost $2 \%$ of their total employment. In oregon, the resource-intensive sectors lost $7 \%$ of their employment. In Washington, the resource-intensive sectors lost. $3 \%$ of their employment.

The major resource-intensive sector in the Pacific states continues to be the wood products sector. The wood products sector was vulnerable to the national recession in the 1970s, especially in Oregon. Oregon's wood product sectors lost about $2 \%$ of its employment between 1970 and 1975. However, employment in wood products increased by $6.4 \%$ in California and by $5.5 \%$ in Washington during the same period.

Another part of the employment losses in manufacturing was related to the employment decline of the U.S. defense industry in 1973-1974. The degree that the economies of the Pacific states is influenced by the health of the defense industry is reflected in the large employment losses in the nonroutine manufacturing sectors between the years 1970 and 1975 (refer to Table XI). The state of Washington lost $21 \%$ of its employment in the transportation equipment sector between 1970 and 1975 (primarily due to the cutbacks at Boeing in seattle, WA). The state of California lost about $11 \%$ of its employment in the knowledge-intensive sectors 
(primarily in ordinance and accessories and electrical machinery) between 1970 and 1975.

The decline in manufacturing in the Pacific states was partially offset by the employment growth in the service sectors between 1970 and 1975. In California, employment in the retail and the personal service sectors increased by 17\%. In oregon, employment in retail and personal services increased by $24 \%$ between 1970 and 1975. In Washington, employment in the retail and personal service sector increased by over $59 \%$.

The industrial restructuring in the Pacific states has not been geographically uniform. Because of disclosure problems found in county Business Patterns, the exact degree of spatial differences is not known, but certain spatial trends are evident from the data (U.S. Census, 1965, 1970b, $1975,1980 \mathrm{~b})$.

1. All the spatial regions (metropolitan $>500,000$, metropolitan <500,000, adjacent nonmetropolitan, and nonadjacent nonmetropolitan counties) gained employment during the turnaround period (see Table XII).

2. In spite, the large losses in resource-intensive manufacturing at the state level in oregon and washington, the nonmetropolitan counties gained manufacturing jobs in the turnaround period. However, the relative share of manufacturing employment declined in the nonmetropolitan counties. 
TABLE XII

EMPLOYMENT BY MAJOR INDUSTRIAL SECTORS

BY COUNTY TYPES, 1965-1975

\begin{tabular}{|c|c|c|c|c|c|c|c|}
\hline & $\begin{array}{l}\text { TOTAL } \\
\text { EAPLOYMENT }\end{array}$ & AGRI CULTURE & $\begin{array}{l}\text { RONTIHE } \\
\text { HFG }\end{array}$ & $\begin{array}{l}\text { NOAROUTINE } \\
\text { MFG }\end{array}$ & $\begin{array}{l}\text { PROOUCER } \\
\text { SERVICES }\end{array}$ & $\begin{array}{l}\text { CONSUANER } \\
\text { RELATED } \\
\text { SERVICES }\end{array}$ & OTHER \\
\hline \multicolumn{8}{|l|}{1965} \\
\hline \multicolumn{8}{|l|}{ TOTAL EHPLOYHENT } \\
\hline $\begin{array}{l}\text { HETRO > 500,000 } \\
\text { HETRO < 500,000 } \\
\text { ADJACENT } \\
\text { NOWAD JACENT }\end{array}$ & $\begin{array}{r}4,453,992 \\
573,320 \\
153,504 \\
394,441\end{array}$ & $\begin{array}{r}15,502 \\
3,957 \\
2,199 \\
3,749\end{array}$ & $\begin{array}{r}1,144,066 \\
134,921 \\
29,687 \\
140,207\end{array}$ & $\begin{array}{r}268,336 \\
2,095 \\
0 \\
0\end{array}$ & $\begin{array}{r}469,780 \\
48,743 \\
9,949 \\
18,037\end{array}$ & $\begin{array}{r}1,551,787 \\
243,286 \\
68,899 \\
146,566\end{array}$ & $\begin{array}{r}1,004,521 \\
140,318 \\
42,770 \\
85,882\end{array}$ \\
\hline \multicolumn{8}{|c|}{ PERCENTAGE OF TOTAL EMPLOYMENT } \\
\hline $\begin{array}{l}\text { METRO > 500,000 } \\
\text { METRO < 500,000 } \\
\text { ADJACENT } \\
\text { NONAD JACENT }\end{array}$ & & $\begin{array}{l}0.3 \% \\
0.7 \% \\
1.4 x \\
1.0 x\end{array}$ & $\begin{array}{l}25.7 \% \\
23.5 \% \\
19.3 \% \\
35.5 \%\end{array}$ & $\begin{array}{l}6.0 \% \\
0.4 \% \\
0.0 \% \\
0.0 \%\end{array}$ & $\begin{array}{r}10.5 \% \\
8.5 \% \\
6.5 \% \\
4.6 \%\end{array}$ & $\begin{array}{l}34.8 \% \\
42.4 \% \\
44.9 \% \\
37.2 x\end{array}$ & $\begin{array}{l}22.6 \% \\
24.5 \% \\
27.9 \% \\
21.8 x\end{array}$ \\
\hline \multicolumn{8}{|l|}{1970} \\
\hline \multicolumn{8}{|l|}{ TOTAL EMPLOYHEHT } \\
\hline $\begin{array}{l}\text { HETRO > } 500,000 \\
\text { METRO < } 500,000 \\
\text { ADJACENT } \\
\text { MONAD JACENT }\end{array}$ & $\begin{array}{r}5,507,769 \\
690,704 \\
179,048 \\
437,039\end{array}$ & $\begin{array}{r}20,549 \\
5,732 \\
2,562 \\
5,100\end{array}$ & $\begin{array}{r}1,316,070 \\
150,666 \\
32,498 \\
142,919\end{array}$ & $\begin{array}{r}367,305 \\
5,029 \\
0 \\
0\end{array}$ & $\begin{array}{r}617,585 \\
71,436 \\
11,818 \\
25,124\end{array}$ & $\begin{array}{r}2,015,093 \\
318,035 \\
88,953 \\
183,794\end{array}$ & $\begin{array}{r}1,171,167 \\
139,806 \\
43,217 \\
80,102\end{array}$ \\
\hline \multicolumn{8}{|c|}{ PERCEATAGE OF TOTAL EMPLOYMEKT } \\
\hline $\begin{array}{l}\text { METRO > } 500,000 \\
\text { HETRO < } 500,000 \\
\text { ADJACENT } \\
\text { KOWADJACENT }\end{array}$ & & $\begin{array}{l}0.4 x \\
0.8 x \\
1.4 x \\
1.2 x\end{array}$ & $\begin{array}{l}23.9 x \\
21.8 x \\
18.2 x \\
32.7 x\end{array}$ & $\begin{array}{l}6.7 x \\
0.74 \\
0.0 x \\
0.0 x\end{array}$ & $\begin{array}{r}11.2 x \\
10.3 \% \\
6.6 \% \\
5.7 x\end{array}$ & $\begin{array}{l}36.6 \% \\
46.0 x \\
49.7 x \\
42.1 x\end{array}$ & $\begin{array}{l}21.3 x \\
20.2 x \\
24.1 x \\
18.3 x\end{array}$ \\
\hline \multicolumn{8}{|l|}{1975} \\
\hline \multicolumn{8}{|l|}{ TOTAL EMPLOYMENT } \\
\hline $\begin{array}{l}\text { METRO > } 500,000 \\
\text { METRO < } 500,000 \\
\text { ADJACENT } \\
\text { NONAD JACENT } \\
\text { - }\end{array}$ & $\begin{array}{r}5,962,104 \\
835,047 \\
214,297 \\
501,648\end{array}$ & $\begin{array}{r}23,610 \\
9,323 \\
4,932 \\
7,583\end{array}$ & $\begin{array}{r}1,252,636 \\
167,958 \\
37,342 \\
153,914\end{array}$ & $\begin{array}{r}401,571 \\
9,552 \\
0 \\
0\end{array}$ & $\begin{array}{r}729,823 \\
75,632 \\
16,179 \\
32,005\end{array}$ & $\begin{array}{r}2,411,042 \\
403,652 \\
103,701 \\
218,073\end{array}$ & $\begin{array}{r}1,143,422 \\
168,930 \\
52,143 \\
90,073\end{array}$ \\
\hline \multicolumn{8}{|c|}{$\begin{array}{l}\text { PERCEHTAGE OF TOTAL EMPLOYHEHT } \\
\text { P. }\end{array}$} \\
\hline $\begin{array}{l}\text { METRO > 500,000 } \\
\text { METRO < } 500,000 \\
\text { ADJACENT } \\
\text { NOMADJACENT }\end{array}$ & & $\begin{array}{l}0.4 x \\
1.1 \% \\
2.3 \% \\
1.5 x\end{array}$ & $\begin{array}{l}21.0 x \\
20.1 x \\
17.4 x \\
30.7 x\end{array}$ & $\begin{array}{l}6.7 x \\
1.1 x \\
0.0 \% \\
0.0 \%\end{array}$ & $\begin{array}{r}12.2 x \\
9.1 x \\
7.5 x \\
6.4 x\end{array}$ & $\begin{array}{l}40.4 \% \\
48.3 \% \\
48.4 \% \\
43.5 \%\end{array}$ & $\begin{array}{l}19.2 \% \\
20.2 \% \\
24.3 \% \\
18.0 \%\end{array}$ \\
\hline
\end{tabular}

Source: Calculated from U.S. Census (1965, 1970b, 1975).

3. The large metropolitan areas lost routine

manufacturing jobs in the turnaround period. The loss of 
routine manufacturing jobs was offset with a substantial gain of nonroutine manufacturing and producer service jobs between 1970 and 1975, even with the lost of a substantial number of nonroutine manufacturing jobs between 1970 and 1975 in the Seattle SMSA. The large metropolitan areas also lost employment in the construction and wholesale trade sectors as well between 1970-1975 (refer to the "other" category in Table XIII).

TABLE XIII

EMPLOYMENT CHANGE BY COUNTY TYPES BY MAJOR INDUSTRIAL SECTORS, 1965-1975

\begin{tabular}{|c|c|c|c|c|c|c|c|}
\hline & $\begin{array}{l}\text { TOTAL } \\
\text { EMPLOYMENT }\end{array}$ & AGRICULTTURE & $\begin{array}{l}\text { ROUTINE } \\
\text { HFG }\end{array}$ & $\begin{array}{l}\text { NOWROUT INE } \\
\text { MFG }\end{array}$ & $\begin{array}{l}\text { PROOUCER } \\
\text { SERVICES }\end{array}$ & $\begin{array}{l}\text { CONSUMER } \\
\text { RELATED } \\
\text { SERVICES }\end{array}$ & OTHER \\
\hline \multicolumn{8}{|c|}{ TOTAL EMPLOYMENT CHANGE } \\
\hline \multicolumn{8}{|l|}{$1965-1970$} \\
\hline $\begin{array}{l}\text { METRO > 500,000 } \\
\text { METRO < } 500,000 \\
\text { ADJACENT } \\
\text { MONADJACENT }\end{array}$ & $\begin{array}{r}1,053,777 \\
117,384 \\
25,544 \\
42,598\end{array}$ & $\begin{array}{l}5,047 \\
1,775 \\
363 \\
1,351\end{array}$ & $\begin{array}{r}172,004 \\
15,745 \\
2,811 \\
2,712\end{array}$ & $\begin{array}{r}98,969 \\
2,934 \\
0 \\
0\end{array}$ & $\begin{array}{r}147,805 \\
22,693 \\
1,869 \\
7,087\end{array}$ & $\begin{array}{r}463,306 \\
74,749 \\
20,054 \\
37,228\end{array}$ & $\begin{array}{r}166,646 \\
(512) \\
447 \\
(5,780)\end{array}$ \\
\hline \multicolumn{8}{|l|}{$1970-1975$} \\
\hline $\begin{array}{l}\text { HETRO > 500,000 } \\
\text { METRO < } 500,000 \\
\text { ADJACENT } \\
\text { NONAD JACENT }\end{array}$ & $\begin{array}{r}454,335 \\
144,343 \\
35,249 \\
64,609\end{array}$ & $\begin{array}{l}3,061 \\
3,591 \\
2,370 \\
2,483\end{array}$ & $\begin{array}{c}(63,434) \\
17,292 \\
4,844 \\
10,995\end{array}$ & $\begin{array}{r}34,266 \\
4,523 \\
0 \\
0\end{array}$ & $\begin{array}{r}112,238 \\
4,196 \\
4,361 \\
6,881\end{array}$ & $\begin{array}{r}395,949 \\
85,617 \\
14,748 \\
34,279\end{array}$ & $\begin{array}{c}(27,745) \\
29,124 \\
8,926 \\
9,971\end{array}$ \\
\hline \multicolumn{8}{|c|}{ PERCEHTAGE CHAHGE IH EMPLOYAERT } \\
\hline \multicolumn{8}{|c|}{$1965-1970$} \\
\hline $\begin{array}{l}\text { HETRO > 500,000 } \\
\text { HETRO < 500,000 } \\
\text { ADJACENT } \\
\text { HOWND JACENT }\end{array}$ & $\begin{array}{r}10.6 x \\
9.3 x \\
7.7 x \\
5.1 x\end{array}$ & $\begin{array}{r}14.0 x \\
18.3 x \\
7.6 x \\
15.3 x\end{array}$ & $\begin{array}{l}7.0 x \\
5.5 x \\
4.5 x \\
1.0 x\end{array}$ & $\begin{array}{l}15.6 x \\
41.2 \% \\
0.0 x \\
0.0 x\end{array}$ & $\begin{array}{r}13.6 \% \\
18.9 x \\
8.6 x \\
16.4 x\end{array}$ & $\begin{array}{l}13.0 \% \\
13.3 x \\
12.7 x \\
11.3 x\end{array}$ & $\begin{array}{r}7.7 x \\
-0.2 x \\
0.5 x \\
-3.5 x\end{array}$ \\
\hline \multicolumn{8}{|l|}{$1970-1975$} \\
\hline $\begin{array}{l}\text { METRO > 500,000 } \\
\text { METRO < } 500,000 \\
\text { AD JACENT } \\
\text { NOWAD JACENT }\end{array}$ & $\begin{array}{l}4.0 x \\
9.5 \% \\
9.0 x \\
6.9 x\end{array}$ & $\begin{array}{r}6.9 x \\
23.9 x \\
31.6 x \\
19.6 x\end{array}$ & $\begin{array}{r}-2.5 \% \\
5.4 \% \\
6.9 \% \\
3.7 \%\end{array}$ & $\begin{array}{r}4.5 x \\
31.0 \% \\
0.0 \% \\
0.0 \%\end{array}$ & $\begin{array}{r}8.3 \% \\
2.9 \% \\
15.6 \% \\
12.0 \%\end{array}$ & $\begin{array}{r}8.9 \% \\
11.9 \% \\
7.7 x \\
8.5 \%\end{array}$ & $\begin{array}{r}-1.2 x \\
9.4 x \\
9.4 x \\
5.9 x\end{array}$ \\
\hline
\end{tabular}

Source: Colculated from U.S. Census (1965, 1970b, 1975). 
4. As in the rest of the nation, the metropolitan and nonmetropolitan counties gained employment in the service sectors.

5. Contrary to the rest of the nation, however, all the regions gained employment in agricultural services.

\section{CHAPTER SUMMARY AND CONCLUSIONS}

A new pattern of human settlement patterns emerged in the United States during the late 1970s. The new emergent pattern showed a population movement away from the larger counties to the smaller counties. There appears to be no uniform pattern of dispersion. Some of the nonmetropolitan counties had population decline, while others had population growth during the pre-turnaround and turnaround periods.

Nationally, the population and economic reconcentration in the 1970s reflected the diversity of resources in both metropolitan and nonmetropolitan counties. There was a decline in dependency on basic sectors and a growth in dependency on the nonbasic sectors in the metropolitan counties. In nonmetropolitan counties, there was a decline in dependency on the agricultural sector and a growth in dependency on manufacturing and service related sectors.

In the Pacific states, population and economic reconcentration did not always parallel the national trends. In the Pacific metropolitan areas, there has been employment growth in the producer service sectors and nonroutine 
manufacturing sectors. However, there has been no relative decline in the agricultural related sectors in the metropolitan counties.

In the Pacific nonmetropolitan counties, the turnaround in employment growth was not a sign of the resurgence of a farm economy. There has been no significant decline or growth in agricultural related employment. Rather there has been employment growth in service related sectors (i.e., retail trade, wholesale and personal services). There has also been employment growth in manufacturing employment, however, that the relative importance of the population employed in the manufacturing sectors has declined. 
THE THEORETICAL REVIEW OF MIGRATION LITERATURE

The purpose of this chapter is to synthesize the scholarly works that deal with the forces behind the nonmetropolitan turnaround of people and jobs. The question is why did the turnaround between metropolitan and nonmetropolitan counties occur? Does this turnaround represent a unique departure from previous patterns of movement? To address these questions requires reviewing the structural changes within spatial regions and the responses of individuals living in these regions to structural changes.

The literature on the impact of structural change on migration transcends disciplines, thus this review incorporates economic, geographical, and socjological works.

WHY THE TURNAROUND OF PEOPLE AND JOBS

Frey $(1987,1989)$ notes the debate on population and economic redistribution evolves from two general theoretical perspectives. A regional restructuring perspective links population redistribution to the industrial reorganization of production. The resultant change in the industrial 
structure leads to selective disinvestment in labor-intensive manufacturing in older industrial production centers (i.e., the manufacturing cities such as Akron, Ohio; Buffalo, New York; Gary, Indiana; and Pittsburgh, Pennsylvania). Industrial production has shifted from the older industrial centers to the newer industrial centers, which offer administrative and research and development functions. The new dominant industrial activities in metropolitan regions thus are producer services and high technology industries (Bluestone \& Harrison, 1982; Frey 1987, 1989; Noyelle \& Stanbach, 1984; Sawers \& Tabb, 1984; Scott, 1988a, 1988b; Scott \& Storper, 1986; Stanbach \& Noyelle, 1982).

The deconcentration perspective links population redistribution to the interaction of residential preferences and firm location decisions (Brown \& Wardwell, 1980; Frey, 1987, 1989; Fuguitt, 1985; Hawley \& Mazie, 1981). The deconcentration literature does not discount the role of changes in technology and production organization. The emphasis is the increased importance of "residential space flexibility," which results from the development of new technologies and social and production organizations (Frey, 1987) . 


\section{INDUSTRIAL RESTRUCTURING}

Changes in technology and the industrial structure have changed the traditional location criteria for firms. Before World War II, regional scholars note that the northeastern cities were the most favored sites for U.S. manufacturing. The northeastern cities contained two thirds of U.S. manufacturing jobs. Most scholars regard the northeast's early comparative advantage to be a result of the region having deep water ports, a highly developed transport system that allowed easy access to natural resources, an educated labor force, and a large market area. since World War II, the newer growth industries (i.e., services, aerospace, and electronics) have become less tied to the above traditional industrial location criteria (Kasarda, 1980).

Vernon (1966) explains industrial restructuring according to the region's product cycle. Growth occurs in three stages. The first stage is the incubation stage, which is the result of the presence of an atmosphere that facilitates research and innovation. The second stage is an export expansion stage, which leads to the exporting of the product outside the region. The third stage is a standardization stage, which involves cost minimization moves toward areas of low factor inputs (Vernon, 1966). According to Thompson (1973), growth in nonmetropolitan counties is a result of a filtering process. 
Metropolitan regions are the natural center for new growth industries. The "true economic base" of large metropolitan regions are the scientists and engineers, the universities and research parks, the financial institutions, the public relations efforts, the transportation and communication systems, and the physical infrastructure. This creates an environment for innovation and new products. However, urban areas will not receive a greater proportion of growth in employment. Instead industries will filter through the system of cities:

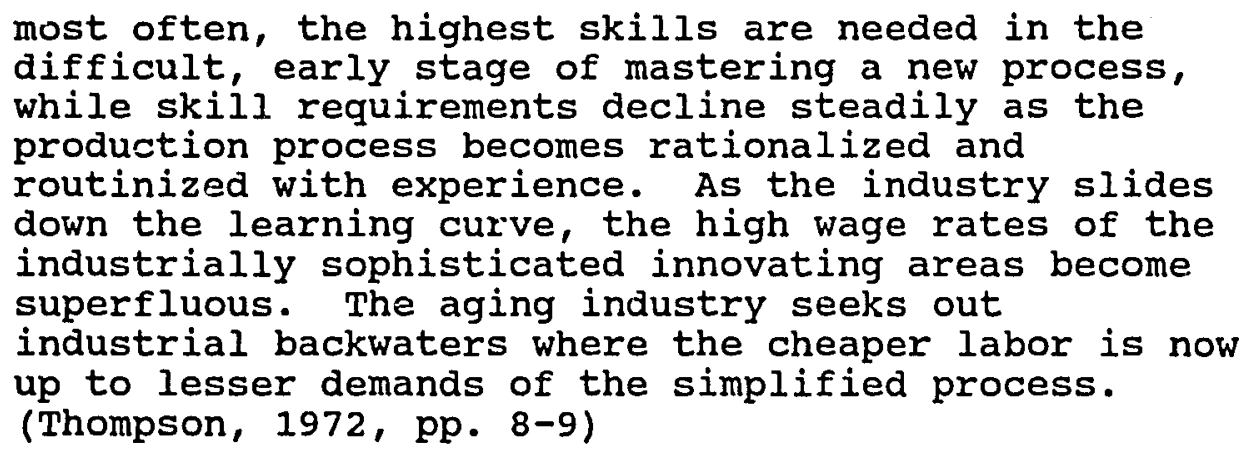

Nonmetropolitan counties are thus expected to acquire the more routjine production facilities and low wage industries, while metropolitan counties will continue to give birth to the newer industries and high wage industries. Thompson (1975c) argues, though, that the more remote nonmetropolitan counties will face "one of three fates: depopulation, socio-economic deterioration or economic absorption" (p. 519). Out-migration is the only alternative, unless these areas are within proximity of metropolitan areas. 
Heaton and Fuguitt (1979) postulate as industrial production reaches a mature stage in the larger metropolitan areas, the availability of agglomeration effects and skilled labor becomes less important, slow growth industries will "filter down" from industrial locations in metropolitan areas to the nonadjacent nonmetropolitan counties. This filtering down process has become easier, since improvements in transportation and communication networks reduced the friction of movement between regions (Heaton \& Fuguitt, 1979)

The change in the industrial structure effects net migration by inducing more industrial expansion and creating new jobs. Heaton and Fuguitt's (1979) study shows nonmetropolitan counties have had a greater rate of manufacturing growth than metropolitan counties have had between 1965 to 1970. However, high wage manufacturing employment continues to grow at a faster rate in the metropolitan and adjacent nonmetropolitan counties, while low wage manufacturing employment grows at a faster rate in the nonadjacent nonmetropolitan counties.

Heaton and Fuguitt's (1979) study indicates that nonmetropolitan counties in the 1950s gained more out-migrants than in-migrants. But by 1970, their study shows that these counties gained in-migrants at a faster rate than metropolitan counties gained. 
Heaton and Fuguitt (1979) find that the growth in nonmetropolitan counties is not solely the result of the relocation of manufacturing to nonmetropolitan counties. According to Heaton and Fuguitt:

manufacturing may have received more attention than it merits as a solution to the problem of nonmetropolitan population decline . . With the growth of a service-oriented economy, manufacturing will further decline in importance. (p. 134)

Bluestone and Harrison (1982) note that changes in technology and organization of work makes it easier for management to use cheap labor in peripheral regions, such as the U.S. nonmetropolitan regions, the U.S. South, or in regions outside of the United States. Consequently, industrial firms are now able to selectively fragment their production processes to nonmetropolitan counties. The new emerging pattern leads to a deskilling of routine production work in metropolitan counties to the peripheral regions (Bluestone \& Harrison, 1982). Thus, it should be expected that routine production manufacturing should decline in metropolitan counties, while routine production manufacturing should increase in nonmetropolitan counties. Noyelle and Stanbach (1984; Stanbach \& Noyelle, 1982) observe that a dual economy is emerging within U.S. regions. Decline in metropolitan regions is a result of a selective disinvestment. older regional production centers (i.e., Akron, Ohio and Buffalo, New York) increasingly are experiencing slow or declining rates of employment growth 
because of rising foreign competition and competition from cheaper U.S. regions. The growing metropolitan centers are those that have administrative functions (i.e., headquarter activities and producer services), distributive functions (i.e., wholesale and transportation services), research and development functions (i.e., high technology manufacturing), and government and nonprofit functions. Strong linkages in the growth centers (i.e., San Jose, California and Seattle, Washington) exist between production activities, administrative activities, and research and development activities (Noyelle \& Stanbach, 1984; Stanbach \& Noyelle, 1982).

Gottdiener (1985) labels the spatial dispersion from the urban core to the periphery an indication of a locational division of labor:

Those firms choosing the central city are more likely to be involved in global and administrative activities, while those firms with distinctively regional ties to the metropolitan economy are dispersing along with other activities to the urban hinterland. (p. 56)

Scott (1988a) postulates that the dispersion process from metropolitan to nonmetropolitan counties in the 1970s in United States is a result of a new spatial and international division of labor. Scott notes that the modern industrial firm locates in space according to its different internal functions, i.e., administrative function, skilled specialized nonroutine production or deskilled, routine production. Administrative functions are located in 
the larger business complexes in metropolitan regions. The skilled production centers are typically growth centers that possess specialized materials and labor inputs. The deskilled functions are in peripheral locations, where labor costs are low and unionization is weak (Scott, 1988a). Consequently, the decentralization trend in United States from the larger metropolitan counties results in traditional manufacturing activities shifting to more remote peripheral locations, while the economies of large metropolitan counties increasingly become dependent on such producer services as financial services, business services, and professional services (Scott \& Storper, 1986).

Kale and Lonsdale (1979) identify several diver'se economic and noneconomic factors that influence plant location decisions in nonmetropolitan counties. These factors are labor availability, labor skills, labor productivity, unionization, transportation, market size, environmental considerations, and energy at the regional level. The more local influences are housing, developed industrial sites, available building, and community liveability.

\section{POPULATION DECONCENTRATION}

Kasarda (1980) provides an extensive theoretical work on why the turnaround in migration of jobs and people happened. Kasarda cites both nonemployment and employment 
reasons for this change, such as the footloose retirement population whose source of income (social security and private pensions) is not tied to any particular location, changes in technology making it easier for individuals to live in extreme weather conditions, rising real incomes in rural areas, less expensive land, improvements in consumer services, and the extension of the interstate freeway system (Kasarda, 1980).

Hawley (1950) views population pressure as the engine of growth behind urban expansion. The expansion process concentrates administrative functions within urban centers. As an urban center grows, the center extends to the periphery (Hawley, 1950). According to Hawley (1971):

The centripetal movement has concentrated administrative offices and institutions, the services that cater to administrative tasks, and the retailing of expensive and fashionable commodities in the central business district of the central city. This movement has been associated with a less conspicuous centralization of control over the metropolitan system. The spatial rearrangement is an external manifestation of a functional reorganization of an enlarging community. (p. 171)

Armstrong (1972) empirically examines Hawley's administrative function hypothesis. Armstrong's data shows that by 1970, about one out of every six corporate headquarters are located outside the central city. Sly and Tayman (1980) also find that as the periphery becomes developed, urban administrative functions begin to disperse away from the central business district to the urban periphery. The dispersion process though is more influenced 
by the region's relationship to the rest of the national and global economy, than a relationship between the metropolitan area's core and periphery (Armstrong, 1972; Gottdiener, 1985; Sly \& Tayman, 1980). In other words, the spillover of metropolitan functions to nonmetropolitan counties located in their peripheral fringe is a phenomenon associated with large metropolitan areas rather than small metropolitan areas.

Berry (1976b) notes that nonmetropolitan growth is a result of the spreading of urban functions into nonmetropolitan regions. The conceptualization of the city itself needs to be redefined. The city is no longer the center of a concentrated cone. A new geographical entity, the urban field, is being created. The urban field is a space that goes beyond the present urban boundaries, with the primary activities oriented toward the city (Berry, 1976b; Friedman \& Miller, 1965). This urban field is a fusion of metropolitan and nonmetropolitan counties. Within this region, the distinction between urban and rural gradually disappears. The city is not a physical entity, instead it has become "a pattern of point locations and connecting flows of people, information, money and commodities" (Friedman \& Miller, 1965, p. 314).

Wardwell (1977) examines whether the nonmetropolitan turnaround represents an extension or departure from the past urbanization process. His study evaluates whether or 
not the cause relates to the presence of an equilibrium in the exchange of population between metropolitan and nonmetropolitan counties, to a change in the composition of the population, to changes in the economic and social structure of nonmetropolitan counties, or to changes in residential preferences.

Residential preferences for smaller places have increased. It should be noted that even though Wardwell's (1977) study finds a preference toward living in smaller places, it is a preference for smaller places within a commuting radius of metropolitan centers. Additionally, declining fertility rates create an age effect on nonmetropolitan growth that may contribute to a decrease in the push effect of nonmetropolitan youth seeking employment opportunities in metropolitan regions.

What needs to be identified are the forces behind the causes of the change. Wardwell (1980) identifies the foremost cause as a "pervasive urbanization." The concept of urbanization is not just a physical space, but also a social organization. "Pervasive urbanization" refers to a society whose:

urban forms of social organization have so extended themselves in space as to make old distinctions between center and hinterland, urban and rural less meaningful than they have. (p. 73)

Frisbie and Poston (1975) are two of the first scholars to address the relationship between nonmetropolitan population change and economic activities. Their study 
focuses on the interrelationship of population change, the sustenance (economic) activities, and the environment. The environmental variables in their study include the racial and age composition and proximity to metropolitan counties. Their empirical results show the nonmetropolitan counties, which are experiencing growth, are counties that are no longer dependent on primary activities (i.e., agriculture and mining). The growing counties' major economic activities are service and food processing activities. Fuguitt, Voss, and Doherty (1979) analyze the interrelationship of the changing structural characteristics of rural counties with net migration rates. Their results show a greater rate of net migration between 1970-1975 associated with the presence of a state college; interstate freeway system; populations with a higher percentage engaged in manufacturing; higher per capita rankings of hotels, motels, and tourist camps; and a higher percentage of the elderly. An extension of their study shows both the social and physical environmental (i.e., presence of college and climate) and economic variables to be statistically significant with migration (Heaton, clifford, \& Fuguitt, 1981).

Zelinsky (1978) as well focuses on the interrelationship of structural change with net migration in his study of nonmetropolitan population change in Pennsylvania between 1940 and 1975. His study analyzes the 
correlation coefficients of population change with net migration, socio-economic status, and distance from the standard metropolitan statistical areas. His analysis discounts the role of traditional economic motivations, socio-economic status, and the friction of distance in recent migration. Although the aggregate results of the study supports the hypothesis of population deconcentration, he notes there is a trend more toward reconcentration than deconcentration. separating the nonmetropolitan counties by proximity to metropolitan areas reveals two distinctive patterns of population reconcentration. The first pattern is the emergence of an inner zone $(25$ to 35 miles distance SMSA), and the second new pattern is the emergence of new centers in the outer zone. The inner zone is attracting migrants from metropolitan counties and the nonadjacent nonmetropolitan counties. Growth in the outer zones is related to the presence of institutions of higher education and recreational facilities.

William"s (1981b) study of midwestern migration examines the interrelationship of nonmetropolitan population growth, employment related factors, and scenic amenities. williams tested the hypothesis of whether or not the turnaround phenomenon is a result of employment related factors or scenic amenities (i.e., percentage of forest land and four-year colleges/universities present). His data consist of aggregate five-year gross migration data for 
state economic areas. His work, unlike previous research, addresses the interrelationship of migration and employment. His study includes such amenities as military population, percentage land forested, presence of a four-year university, and a measure of proximity to metropolitan areas. The amenity variables perform poorly compared to the economic variables in his model results.

Bradbury, Downs, and Small (1982), on the other hand, do not focus on nonmetropolitan growth, but on why urban decline is happening. They postulate urban decline has two meanings: descriptive and functional. Descriptive decline "refers to any decrease in such measures of size as population or employment" (p. 18).

Functional decline refers to "changes that impair the functioning of a city or other urban agglomeration" Bradbury, Downs, \& Small, 1982, p. 18), such as support systems, creative innovation, residential environments, and economies of scale. To test this theory, their study examines 121 metropolitan areas between 1970 and 1975 to determine whether descriptive or functional decline happened. The variables selected to measure descriptive decline are employment and population. The variable for per capita income change measures functional decline. The cross section regression results show that population growth and employment are strongly related. It is unclear which comes 
first. Firms tend to stay in cities where incomes are growing and where the economic base is diversifying. Wardwell and Gilchrist (1980) studied both metropolitan and nonmetropolitan counties to determine the causes of economic concentration and the population turnaround. The attention of their study is on the relationship of net migration rates with the characteristics of metropolitan and nonmetropolitan counties and the role of employment. Their study combined the Continuous Work History Sample and the Human Resources Profile to obtain shifts in employment location. County characteristics are related to the size of counties, i.e., whether large, medium or small metropolitan, or nonadjacent or adjacent nonmetropolitan counties to SMSAs. Their analysis shows a negative correlation between size and migration rate (the larger the size, the smaller the in-migration rate). As for nonmetropolitan counties, all sizes and types of counties whether adjacent or nonadjacent had positive net migration rates. Although Wardwell and Gilchrist set out to study the relationship between employment and county characteristics, their study does not examine the relationship between diversity of the employment structure or the amenities with migration flows. 
MOTIVATIONS FOR MIGRATION: THE INDIVIDUAL'S RESPONSE TO STRIJCTURAL CHANGE

There are numerous studies on the motivations of migrants. Previous rnigration studies in 1946 and 1963 show the primary motive for all moves is job related (Lansing \& Mueller, 1967; U.S. Dept of Census, 1966). Employment versus nonemployment factors depend upon such migration characteristics as age, education, income, and sex. Employment moves are related positively to education, income, and occupation status (Roseman, 1983).

A more recent study by Long and DeAre (1980) still finds the primary motive for metropolitan to nonmetropolitan moves to be job related, followed by closeness to relatives, family related reasons, and retirement. However, williams and Sofranko's (1979) study of the Midwest shows environmental influences to be the prime motive for leaving metropolitan counties, while nonmetropolitan migrants move for job related reasons.

Fuguitt, Voss, and Doherty's (1979) study examining the motivation of nonmetropolitan migrants in the Upper Great Lake region reveals both employment and nonemployment reasons for migrants leaving their place of origin. For nonmetropolitan migrants under the age of 50 , the primary reason for moving to a place is job related. The next most cited reason is previous ties to other places, and then anti-urban reasons are listed. For migrants over the age of 
50, the major reason for leaving a place is retirement and the major criteria of selection is previous ties to a place. Stevens' (1980) research differs from Fuguitt, Voss, and Doherty's (1979) research. The goal of his study was to determine consumer revealed preferences for public goods, such as safety, congestion, air quality, and family recreation. To do this, stevens used both hedonic price and utility function models to test his survey results. His results show migrants to Jackson and Josephine counties in oregon, actually make modest income sacrifices in order to gain environmental amenities.

\section{CHAPTER SUMMARY AND CONCLUSIONS}

Although the literature on why migrants move to nonmetropolitan counties is extensive, the results are not comparable. The most frequently cited reasons for moving, such as environmental push, employment, social ties, environmental pull and retirement, are found across nonmetropolitan regions from studies on the ozarks, Midwest, Ohio, and Oregon (Fuguitt, Voss, \& Doherty, 1975; Kuehn, 1979; Roseman, 1983; Sofranko \& Williams, 1980; Stevens, 1980). Most studies, according to Fuguitt, Voss, and Doherty, lack " . . comparable information about persons outside the survey boundaries and in particular, they tell us nothing about the counterstream" (p. 35). 
Field surveys give elaborate responses to questions why a person moved to an area, but the results of these surveys do not explain why the turnaround happened, nor what factors made it possible for migrants to move to an area and obtain "the rural amenities."

Nor does the economic literature explain the turnaround. Recent economic studies point to the decline of employment variables as determinants in migration (Fuguitt, Voss, \& Doherty, 1979; Lansing \& Mueller, 1967; Wardwell \& Gilchrist, 1980). Frequently, these studies cite that the labor migrant is making tradeoffs between his preferred environment and wages (Mazek \& Laird, 1974; Stevens, 1980). The regional development literature postulates that nonemployment factors, such as physical environment and community liveability, affect the location choice of firms (Kale \& Lonsdale, 1979; Kasarda, 1980). The problem in studying the turnaround of jobs and people in the 1970s, however, is that traditional economic theory cannot explain the relevance of amenities and accessibility.

To address this problem requires developing a research model that examines the relationship between employment factors and nonemployment factors. From the literature review presented in this chapter, the nonemployment factors can best be categorized as the socio-physical environment and accessibility. The socio-physical environment consists of site and situation factors that influence the local 
employment opportunities and residential preferences, such as socio-economic status, recreational amenities, education facilities, and climate (Frisbie \& Poston, 1975; Fuguitt, Voss, \& Doherty, 1979; Karp \& Kelly, 1971; Sly, 1972). 
CHAPTER IV

\section{MODEL SPECIFICATION FOR LABOR FORCE MIGRATION AND ECONOMIC DECONCENTRATION}

This chapter describes the research model used to examine the determinants of labor force migration and economic deconcentration in the three Pacific states. The theoretical basis of the research model is an integration of economic, geographical, and sociological works on migration. The first section of this chapter outlines the theoretical foundations of the research model. The second section presents the research hypotheses to be examined in this study. The third section discusses the variables to develop the research model. The fourth section outlines the data collection process for this study.

The conceptual approach in this study comes from the human ecological school. The human ecology literature provides a framework for analyzing the relationship between population, the environment, sustenance (economic) organization, and technological change (Duncan, 1959).

Human ecology, which is a subdiscipline within sociology, examines the relationship of human communities interaction with their surrounding environment (Hawley, 1968). The primary focus of human ecology is on the functional systems that exist within a population. 
The four distinctive aspects of human ecology relevant to population studies are:

1. Human organizations evolve from the interactions between population and its envirorment.

2. Population is the point of reference for study of human organizations.

3. Human organizations, themselves, are closed systems.

4. The components of the ecological system move toward equilibrium.

This movement occurs in a series of sequential steps. However, a steady state equilibrium will never occur, only an approximation or new equilibrium happens. In other words, the system is not static, but a moving system. The population within a community consists of the aggregate of the individuals. The environment consists of the site and situation factors that affect the community. site factors are physical (such as climate, land, or forest). Situation factors are social (such as racial mix of population, cultural or education facilities in a community or amount of schooling completed). The sustenance organization consists of those activities from which the population obtains its livelihood.

The relevance of human ecology for migration research is its theoretical assertion that population redistributes itself either through changes in fertility and mortality or 
through migration to achieve an equilibrium between population size and economic survival (Hawley, 1968, p. 331). A refinement of the population hypothesis is that population redistribution is a direct "demographic response to differences in sustenance organization" (Sly, 1972, p. 615). In brief, economic activities have a direct influence on migration.

Frisbie and Poston (1975) assert the influence of economic activities on migration depends on the nature of the sustenance activity, i.e., whether the activity is agricultural, mining, manufacturing, or services. The population within a community changes according to whether the economic activities decline or grow.

The variables used to represent the ecological complex for the turnaround in labor force migration in this study are labor migration flows, economic activities, accessibility, and socio-physical ervironment (see Figure 4).

To understand the migration process, one must examine the structural characteristics of the nonmetropolitan counties. The literature review shows little differences between nonmetropolitan and metropolitan living. In the United states, nonmetropolitan counties have become urbanized. 


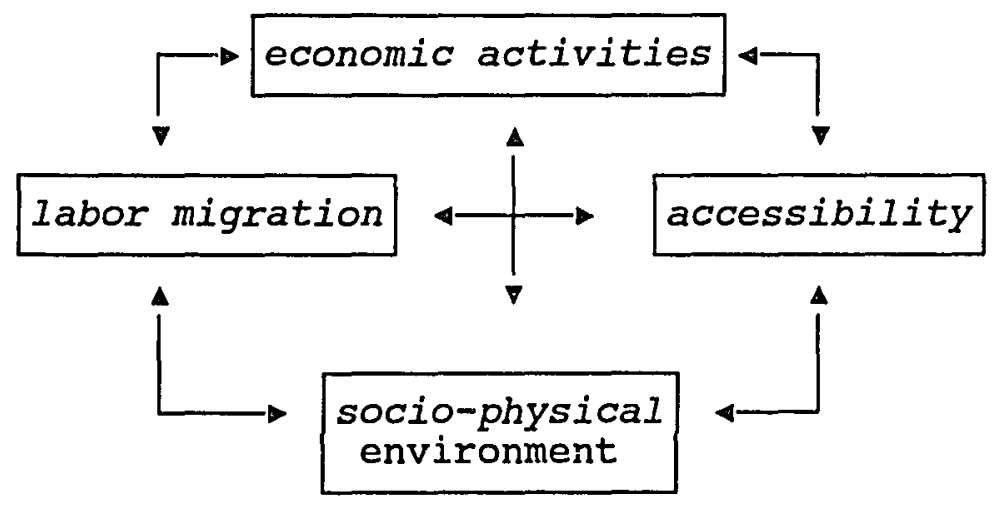

Fiqure 4. The ecological relation of labor migration.

The following section discusses how the socio-physical environment, accessibility, and economic activities should affect the migration process.

\section{HYPOTHESES}

First, the relevance of income has declined because of changes in the employment structure. The location of manufacturing activities is no longer a function of traditional location criteria. Between 1960 and 1970, the growth rate of manufacturing was $9.9 \%$ in metropolitan counties and $27.5 \%$ in nonmetropolitan counties. Between 1970 and 1980, employment in manufacturing grew at a slower rate in metropolitan counties than it grew in nonmetropolitan counties ( $7.7 \%$ compared to $20.7 \%)$. This increase in manufacturing employment in nonmetropolitan counties generated additional employment in the service and retail sectors. It is these diversified opportunities that allow residents, in-migrants, and returnees to the 
nonmetropolitan counties in the Pacific states to reside in locales which offer their preferred living conditions. Second, the presence of physical and social amenities attracts labor in-migration. The preference literature on nonmetropolitan counties reveals a potential reservoir of movers to nonmetropolitan counties who desire to move away from or escape from the disamenities in the larger metropolitan counties.

Third, an expansion of service related activities leads to increased labor in-migration in nonmetropolitan counties. The expansion of service related activities will create a wider range of goods and services, making smaller communities more attractive as centers for shopping and consumer and social services. In brief, the increased growth of retail services, consumer and social services, and entertainment services should provide new and old residents in nonmetropolitan regions the opportunity to acquire more urban services.

Fourth, the presence of interstate highways leads to an increase in employment activities. The completion of the Pacific coast's interstate freeway system in the 1960 s facilitates both personal and business interaction over a wider range of space. The improved access for nonmetropolitan counties closely connected to the freeway permits relocation of manufacturing and other economic 
activity away from the traditional metropolitan centers of industry and commerce.

What are the hypothesized county characteristics that makes one area more attractive than another county to labor migrants? The following section outlines what are the expected relationship between the individual variables in the research model with labor migration and employment growth.

\section{ENVIRONMENTAL AMENITIES ATTRIBUTES}

1. Socio-Economic Amenities. The areas that are growing are areas with better "perceived" quality-of-life. Lower crime rates, the presence of local four-year colleges, and a small percentage of nonwhite population are the variables most frequently mentioned in the literature that represent the "quality-of-life" attributes that attract labor migrants.

2. Physical/Leisure Related Amenities. The presence of physical amenities, such as recreational opportunities and climate, attracts labor migration flows. If labor migrants are moving to nonmetropolitan counties to acquire an outdoor quality-of-life, then labor migration flows should be positively associated with recreational opportunities and negatively associated with adverse climate. 
3. Cost of Living. Higher costs of living have a negative influence on labor flows to nonmetropolitan counties. A major component of cost of living is housing, which on the average accounts for $25-35 \%$ of all household expenditures. Nonmetropolitan counties that have higher labor in-migration should be the counties with lower housing costs.

4. Areal Income Differentials. Areal income differentials do not have a significant effect on labor in-migration to nonmetropolitan counties. However, labor in-migration to large metropolitan counties should be related to income differentials.

5. Unemployment. Unemployment will have a negative influence on labor migration flows. One of the basic assumptions of the neoclassical economic model is areas that lack job opportunities are the least attractive to labor migrants (Borts \& Stein, 1964). A measure of the lack of job opportunities is the level of unemployment in a region (Greenwood, 1981).

\section{ACCESSIBILITY}

1. Labor Potential Index. The potential for the interaction of labor flows leads to an increase in labor migration. The potential interaction of labor migration flows between two regions is a function of the population size of the two regions. The underlying assumption of a 
spatial interaction model is that the potential volume of interaction between the two regions is inversely related to the distance between the two regions. This study calculates the potential index by multiplying the populations of the two regions and then dividing by the physical distance that separates the two regions.

\section{ECONOMIC ACTIVITIES}

\section{Employment Availability. An increase in} manufacturing and service employment leads to an increase of labor in-migration and a reduction of labor out-migration in nonmetropolitan counties, primary agriculture ceases to be a dominant activity, and manufacturing and services become the dominant activities.

3. Controlled Access Highways. Proximity to better high quality controlled access highways leads to increased employment activities because it reduces the transaction costs for exchange of goods and services between metropolitan and nonmetropolitan counties.

3. Production Input Factors. Low cost production factors, such as wage rates and industrial energy rates, lead to an increase in employment activities, and thus make the region more attractive to labor in-migrants.

4. Goods and Services. The availability of a wide range of goods and services makes a community more attractive to labor migrants. One indicator of the quality 
of goods and services is the proportion of consumer services (nongovernmental) and retail employment divided by the total population. This measure will capture both the relative consumer amenities and service employment available to the population.

\section{Elderly Population. A large percentage of} population of 65 and over leads to an increase of nonbasic employment growth, which leads to increased labor in-migration. Population growth of persons over 65 adds to the county's population and income base (with their retirement and social security pensions) because their spending creates a multiplier effect, which leads to more job opportunities available for labor in-migrants.

\section{MODEL SPECIFICATION}

The following section discusses the specifics of how the research model is implemented. The unit of observation is the interaction of labor flows between counties in California, Oregon, and Washington. The model is a disaggregate flow model with four dependent variables: labor in-migration flows, labor out-migration flows, basic employment growth and nonbasic employment growth. The criteria for selecting attribute variables evolves from the human ecological model. The disaggregated flow model for this study specifies the relationship between labor migration flows and the attribute variables is as follows: 
Labor In-migration Flows $=\underline{F}$ (environment, employment activities, and accessibility).

Labor out-migration Flows $=\underline{F}$ (environment, employment activities, and accessibility).

\section{Variable selection}

As noted by other studies, labor migration flows are responsive to both quality-of-life variables and economic opportunities (Cebula \& Vedder, 1973; Liu, 1975a). operationalizing amenity and economic opportunities variables, however, is very subjective. Liu specifies quality-of-life variables with both economic and noneconomic components. His economic indicators include such measures as community economic health, material wealth, and goods and services. Liu's noneconomic variables include measures of the physical environment, and political and social factors. In brief, Liu's quality-of-life index does not separate economic and noneconomic variables. The thesis of this study is that social and physical quality-of-life variables are the noneconomic site and situation factors in a county, and that economic variables are the sustenance activities within a county.

This study specifies the social and physical environmental variables as site and situation factors. The site factor used to measure environmental amenities is the recreational opportunities index. The situation factors used in this study to measure environmental amenities are 
enrollment in four-year institutes of higher education, the relative county income differences as measured by the ratio of the median income in the county and the median national income, and the average number of years of education completed. The site factors used to measure environmental disamenity variables is the combination of heating degree days and cooling days. The situation factors used to measure environmental disamenities are crime index, age dependency, and the economic health variables. The economic health variables used for this study are unemployment and relative housing costs (Fuguitt, Voss, \& Doherty, 1979; Frisbie \& Poston, 1975; Karp \& Kelley, 1971; Sly, 1972). The recreational opportunities index measures the outdoor recreational attractiveness. The index is derived from a factor score index that combines the supply and demand activities for outdoor recreation in the individual counties. The data source for supply activities is the State County outdoor Recreation Plans (SCORP) for California (California Department, 1979; Center for Continuing, 1982), Oregon (Oregon State Highway, 1967; Oregon State Parks, 1983), and Washington (Washington State Interagency, 1983). These reports provide information on the supply of such facilities as community and neighborhood parks, swimming pools, boating ramps, biking trails, golf holes, and number of picnic tables, etc. Due to the inconsistency in reporting demand activities, this study uses reports from 
various state agencies and the SCORP reports to calculate participation rates for recreational activities (i.e., hunting/fishing, boating, swimming, hiking and picnicking) to measure the demand variables. The outdoor recreation index is the aggregation of the factor scores for each of the demand and supply components of recreational activities. The accessibility variables in this dissertation are labor potential, contiguity, and population size. Traditionally distance is used in migration models as a measure of accessibility. Distance serves as a surrogate measure of psychic, information, and social costs to migration.

This study modifies the spatial interaction model to develop a labor potential index. Population size is a measure of potential employment. The numeric expression is based on Duncan's (1959) population potential index. The specification of the labor potential index in this dissertation is $\mid$ as follows in Figure 5 .

The lack of agreement in the literature as to the correct specification of the distance exponent creates a problem in calculating the above index. Numerous scholars use ordinary least squares (OIS) to estimate the distance coefficient in the spatial model (Ballard \& Clark, 1981; Carrothers, 1956; Fotheringham \& Webber, 1980; Sheppard, 1979). Knowledge of this distance coefficient is 
"potentially the most important aspect of a gravity model parameter estimate" (Fotheringham \& Webber, 1980, p. 33).

$$
\begin{aligned}
L_{i j}=\underline{f}\left(P_{i}, P_{j}, d_{i j}\right) \cdot N \quad k \quad \sum \quad P_{i} P_{j} \\
L_{i j}=\frac{i=1}{\sum_{i=1}^{N} d_{i j}^{B}}
\end{aligned}
$$

where $L_{i j}=$ labor potential index

$$
\begin{aligned}
& P_{i}=\text { population of origin county } \\
& P_{j}=\text { population of destination county } \\
& d_{i j}=\text { distance between } i \text { and } j \\
& B=\text { distance exponent }
\end{aligned}
$$

Fiqure 5. Labor potential index.

Thus, the method used to obtain the most reliable estimate for the distance coefficient must be one that minimizes spatial biases. Sheppard (1979) concludes the:

spatial autocorrelation in the "mass term" of a gravity model produces a nonlinear relationship between the independent variables of a log-linearized gravity model, biasing its oLs estimates. (p. 131)

Sheppard proposes that various functions relating to distance and attractiveness could be separated and perhaps accurately estimated by nonlinear least squares (p. 131). 
For this study, it is proposed to estimate the distance coefficient for the labor potential index by using the following nonlinear model:

Labor Potential $=\beta_{0}+B_{1} * \ln P_{i}+B_{2} * \ln P_{j}-B_{3} * \operatorname{lnd} d_{i j}+\varepsilon$ The value of the distance coefficient $\left(B_{3}\right)$ in the labor potential index for each of the origin and destination interactions thus is the estimated value that results from the calibration of the above nonlinear model. This may create a problem in the overall labor flow model, since the dependent variable to calculate the distance elasticity is labor flows. However, the mass term of the labor potential model is independent of labor flows. The advantage of calculating the labor potential index is that each pair of interactions has a unique value. This is the only variable in the model that varies with the number of cases.

There is a problem using a log linear transformation between points that have zero interactions, since the logarithm of zero is undefined. Some researchers suggest that zero interactions be dropped, but this solution would overlook the low volumes of interaction between certain origins and destinations. The most commonly used solution for zero interactions is to add a constant term to the zero flows (Fotheringham \& O'Kelly, 1989; Sen \& Soot, 1981). Sen and soot argue that 0.5 is the appropriate constant term for zero interactions (Fotheringham \& O'KeJ.ly, 1989). 
Another concern in spatial modelling is that moves between adjacent counties may be a function of the tendency of similarity between neighbors rather than the distinct spatial characteristics of two regions. To determine whether adjacency has a significant influence on labor migration flows, a dummy variable, contiguity, is used to represent moves between counties that are adjacent to each other. If a move is between adjacent counties, the dummy value is one. If the move is not between adjacent counties, the dummy value is zero.

This study specifies the economic activities by whether it is a basic activity or nonbasic activity. The basic activities are employment opportunities, relative wage rates (the ratio of a county's wage rates to the national wage rates), industrial energy costs, and access (the presence of controlled access highways). Nonbasic activities are employment opportunities, relative wage rates, and the proportion of the population over 65 .

Basic activities are those economic activities that are oriented to the external demand for the produced goods, i.e., manufacturing. Nonbasic activities are those activities that are oriented toward serving the internal demand of the region's population, i.e., services (see Table XIV) . 
TABLE XIV

INDUSTRIAL CLASSIFICATION USED TO IDENTIFY

EMPLOYMENT ACTIVITY VARIABLES

BASIC ACTIVITIES

NONBASIC ACTIVITIES

Agricultural Services

Routine Manufacturing

Food Processing

Tobacco Manufacturing

Lumber and Wood Products

Furniture and Fixtures

Paper and Allied Products

Printing and Publishing

Chemicals and Allied Products

(Excluding 282)

Petroleum and Coal Products

Rubber and Misc. Plastics

Leather and Leather Product

Stone, Clay, and Glass Products

Primary Metals

Fabricated Metals

Machinery, Except Electrical

(Excluding 357)

Electric and Electronic Equipment

(Excluding 362, 366, and 367)

Transportation Equipment

(Excluding 372)

Instruments and Related Products

(Excluding 381, 382, 384, 385)

Nonroutine Manufacturing

Health Related

Electronics

Defense Related

Instruments

Producer Services

Financial Services

Business Services

(SIC 73, 81, 82, 86)

Consumer and Personal Services

Retail Trade

Services

(Excluding Business Services)

Government Services

Local

State

Federal 
Activities are classified according to whether they are basic or nonbasic using a modified export base model approach. However, there are several weaknesses in using export base models. One is the inability to identify exactly which economic activities are basic and nonbasic (Isserman, 1977). The usefulness of export base models is imited by the assumption that requires growth to be primarily a function of exports. Additionally, the model has other restrictive assumptions such as not considering size of an area, feedback effects, and agglomeration economies. Nevertheless, scholars think the model is useful as a descriptive tool for understanding metropolitan and nonmetropolitan employment change (Kale, 1989). This study categorizes manufacturing activity by whether its production activity is routine or nonroutine (see Table XV). As used here, routine manufacturing includes the traditional manufacturing industrial sectors, i.e., lumber/wood products, food processing, primary metals and fabricated metals. Nonroutine manufacturing includes the knowledge-intensive production sectors. According to the product cycle theory, routine manufacturing activities should filter from the large metropolitan counties to the nonmetropolitan counties (Rees, 1979; Thompson, 1975a, 1975b, 1975c). In contrast, nonroutine manufacturing should agglomerate in metropolitan regions. 
TABLE XII

IDENTIFICATION OF VARIABLES USED TO MEASURE

NONROUTINE MANUFACTURING

SIC CODE

INDUSTRIAI SECTORS

Health Related

282

283

Plastics

Bio-Products

Electronics

357

362

Electronic Computing, Scales/Balances

366

367

Industrial controls

Radio and TV Transmitting

Electronic components and connectors

Defense Related 372

Aircraft Parts and Equipment

Instruments

381

382

384

385

Engineering, Lab and Science

Scientific Instruments

Dental and orthopedic Instruments

othalmic Equipment

Source: Office of Technology Assessment (1984).

This study argues that producer services such as

financial services, banking, and professional services serve not just the local economy but serve the national economy as well. Therefore, this study refines the basic and nonbasic dichotomy by recognizing the changes in the export base. The thesis of this study is that growth in nonbasic services is not the cause of the resurgence of nonmetropolitan counties. The resurgence is dependent on the growth in the basic sectors. Local economic activities are compared to the national levels to determine the relative increase or 
decrease of employment opportunities available to the population. If the region's employment growth rate is similar to the national growth rate, the region would not offer any comparative economic advantage. The decision to use population as the base for comparison is determined by the need to examine per capita distribution of such amenities as consumer goods and services and employment opportunities (see Figure 6).

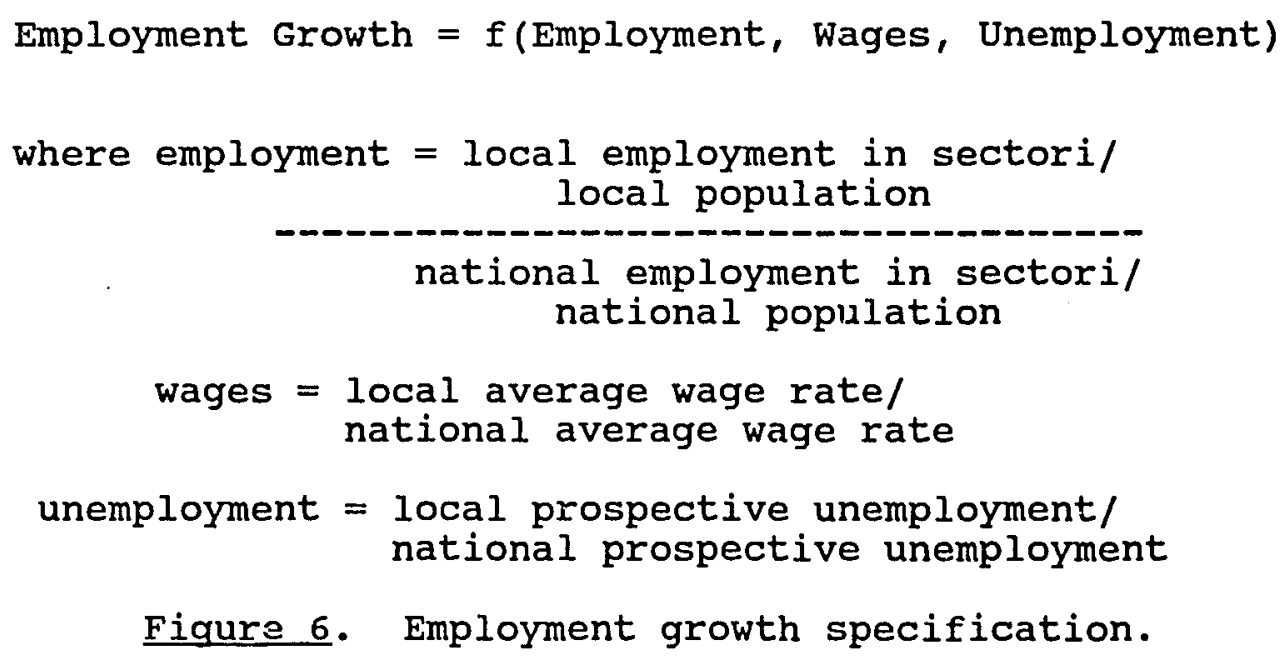

Fiqure 6. Employment growth specification.

This study uses location quotients to describe whether the employment growth in the counties of the Pacific states offers relatively more employment opportunities than the rest of the United States. The focus of this study is not to identify export based activities, but to determine whether the employment activity has a greater level of concentration than the rest of the nation. By using location quotients, one can determine which employment sectors have relatively more employment in a 
particular county than the rest of the nation. According to export base theory, the sectors that have relatively more employment concentration in a county than the rest of the nation are the sectors that export products and services (Perloff \& Wingo, 1961). Perloff and Wingo postulate that as a region expands its markets

Conditions may develop for self-reinforcing and
self-sustaining regional growth and new internal
factors may become important in determining the
rates of regional growth, such as external
economies, associated with social overhead capital
and agglomeration of industries, and internal
economies of scale. (pp. 200-201)

Employment growth in a region, therefore, depends not just on a region's internal demand, but demand in the rest of the nation as well (Weinstein, Gross, \& Rees, 1985). Regional scholars view the recent growth in the south and the west in the 1970 s as support of the export base hypothesis. Nationwide demand of energy products induces regional employment growth through its strong linkages to other sectors in the energy rich states (i.e., Texas, Oklahoma, and Louisiana).

Some proponents of the export base theory argue that a sign of regional decline is when more residents in a region become dependent on the nonbasic sector for their livelihood than on the primary (i.e., mining and agriculture) and secondary sectors (i.e., manufacturing) sectors (Miernyk, 1977). 
Problems Encountered in

Migration Modelling

The causality problem is a major problem associated with migration modelling. Since Muth (1972) first addressed this causality problem in labor migration, others found similar problems in spatial models as well (Fotheringham \& Webber, 1980). Greenwood's (1975, 1981) research shows that migration to metropolitan areas is self-reinforcing, there exists an interrelationship between in- and out-migration and employment growth, which makes it difficult to determine which comes first.

Chalmers and Greenwood (1977) postulate that migration to nonmetropolitan counties is self-reinforcing. Regions with higher rates of employment growth attract in-migration and regions with higher rates of in-migration attract economic growth. In other words, the Keynesian multiplier effect generates more income and thus more employment opportunities. This is consistent with Myrdal (1957) and olvey (1972) who hypothesize that in-migration may stimulate growth and out-migration may contribute to further decline in sending regions.

To overcome the multi-dimensional problems of modelling labor migration and exployment growth, this study specifies a system of simultaneous equations for labor in-migration flows, labor out-migration flows and employment growth. Quite often in demographic and economic modeling, the migration process is best represented with a series of 
simultaneous equations. This type of model treats employment and migration as simultaneously determined by the interactions of migration flows and employment in a spatial region. Previous migration studies find the ordinary least squares estimation of individual equations for migration and employment growth leads to biased and inconsistent parameters (Greenwood, 1975; Muth, 1971).

The two stage least squares method provides a method for obtaining values for structural equations in overidentified equations (equations in which there exist no unique estimation). To solve the simultaneous equations, the two-stage least squares method does two basic steps:

1. First, it creates an instrument variable from its predetermined variables. For the migration model, two-stage least squares estimation creates an employment growth model based upon its predetermined variables (employment opportunities, wage rates and utility costs).

2. Second, in the next stage, ordinary least squares uses the estimated employment growth variable to estimate the migration model.

\section{Specifying the Model to be} Examined

The following section describes the labelling of the variables used in this study. The operationalized model for this dissertation will be specified according to the 
following relationships (exogenous variables are inside parentheses):

In-migration $=\underline{F}$ (Out-migration, Basic Employment, Nonbasic Employment, (Environmental Amenities, Environmental Disamenities, Accessibility))

out-migration $=\underline{F}($ In-migration, Basic Employment, Nonbasic Employment, (Environmental Amenities, Environmental Disamenities, Accessibility))

Basic Employment $=\underline{F}$ (In-migration, Out-migration, Nonbasic Employment, (Agricultural, Manufacturing, Producer, Energy, Wages, Freeway))

Nonbasic Employment $=\underline{F}($ In-migration, Out-migration, Basic Employment, (Personal Services, Retail, Government, Retirement, wages))

Labelling of Individual

Variables

The following section lists the labels for the variables to be used in this study. Endogenous Variables:

In-migration $=$ Number of Labor in-migrants

Out-migration $=$ Number of Labor out-migrants

Basic = Change in basic employment growth in five year period

Nonbasic $=$ Change in employment growth in consumer services and retail trade sectors in five year period 
Predetermined or Exogenous Variables:

Environmental Amenities Variables:

College $=$ college enrollment in four-year institutes of higher education

Expenditures = Educational expenditures per pupil

Recreation = Recreational opportunities index

Income $=$ Income structure

Environmental Disamenities Variables:

Age = Age dependency ratio

Unemployment $=$ Employment potential

Crime $=$ Crime rate per 1,000

Climate = climate (number of heating/cooling degree days)

Nonwhite $=$ Percentage of population who is nonwhite Housing = Value of housing unit

Accessibility Variables:

Freeway $=$ Presence of interstate freeway

Contiguous $=$ Contiguous status, whether moves are to adjacent county

$\mathrm{L}_{\mathrm{ij}}=$ Labor potential index

Economic Activity Variables:

Basic Employment Variables:

Agriculture $=$ Percentage local agricultural sector/percentage national agricultural sector

Routine Manufacturing = Percentage local manufacturing sector/percentage national manufacturing sector 
Nonroutine Manufacturing = Percentage local

manufacturing sector/percentage national manufacturing sector

Producer $=$ Percentage local business sector $/$ percentage national business sector

Wages $=$ Local average wage rate/national average wage rate

Energy = Industrial energy rate

Nonbasic Employment Variables:

Retail = Percentage local retail sector $/$ percentage

national retail sector

Service $=$ Percentage local consumer sector/percentage national consumer sector

Government $=$ percentage local government sector/percentage national government sector

Wages $=$ Fercentage local average nonbasic wage rate/percentage national average nonbasic wage rate Retirement $=$ Percentage population over 65

DATA SOURCES

The data source used for labor migration flows is the Continuous Work History File developed from Social security Records (U.S. Economic, 1976a). The Social Security Administration compiled the data for counties and maintained the data annually from the years 1957 to 1975 (U.S. Economic, 1976b). 
There are several limitations associated with this data file. The data file provides only geographical changes in employment and does not include changes in county of residence. Another problem is that the social security system covers only $90 \%$ of the labor force. Excluded from the data base are workers entering or leaving the labor force. The file has also been found to include errors in the self-reporting of employers. In particular, multi-plant firms do not give the correct breakdown of employment for each plant. In addition, the data file contains coding and clerical errors (Wardwell \& Gilchrist, 1980).

The CWHS (U.S. Economic, 1976a) is appropriate for this study, since the main purpose is to study labor force migration not population migration. Other geographical files such as the current Population Surveys and the Internal Revenue Service data show similar patterns of labor migration as the CWHS data file shows (Wardwell \& Gilchrist, 1980). The advantage of using CWHS or the Internal Revenue Service data is that counties are the unit of analysis. According to Wardwell and Gilchrist (1980), the greatest strengths of the CWHS file have not, been tapped - . when CWHS data are combined at the county level with data sets that provide detailed characteristics of counties of origin and destination, they can very effectively be used to categorize counties by examining the relationships between the resulting typologies and the numbers and the types of employed migrants who are changing their employment location from one county to another. If county population centroid is one of those characteristics, control over distance of 
moves over a given minimal distance, the question of residential mobility can be addressed. Thus, for example, if analyses were restricted to changes that involved 100 miles or more between county centroids, commuting between old residence and new employment location would not be an issue. (p. 155)

The CwHS file allows a researcher to focus on the determinants of labor force migration rather than population migration. Population and labor force migration flows may respond differently to conditions that prevail at the origin or destination. According to Isserman, Plane, and McMillen (1982), the CWHS migration file. . "offer[s] a picture of labor force flows unobscured by changes in residence and by the movements of the retired elderly, of college students, and of young children" (p. 286).

\section{SECONDARY DATA COLLECTION PROCESS}

The socio-economic variables were collected from various secondary data sources, state and local government agencies, and private/public utility agencies. The utilization of these data in the research process is outlined below.

The data used to estimate the two labor change equations came from four primary sources: U.S. Census County Business Patterns $(1965,1970 \mathrm{~b}, 1975,1980 \mathrm{~b})$, U.S. Census City County Data Book (1962C, 1967c, 1972c, 1977c), state employment reviews for California (California Department of Employment, 1965, 1970, 1975), Oregon (Oregon Employment Division, 1965, 1970, 1975, 1980), and Washington 
(Labor Market, 1965, 1970, 1975), and Federal Statistics for Publicly and Privately Owned Utilities in the United states (U.S. Energy, 1965, 1970, 1975).

Data for private sector employment come from the County Business Patterns data series (U.S. Census, 1965, 1970b, 1975, 1980b). This data series provides civilian employment for industrial sectors, i.e., manufacturing, agriculture, finance, producer services, retail and personal services. For employment in the government sector, there is no single data set that could be relied upon. The state employment reviews for California (California Department, 1979; Center for Continuing, 1982), Oregon (Oregon Employment Division, 1965, 1970, 1975), and Washington (Washington State Employment, 1965, 1970, 1975) provide data for state and local government employment at the county level. The U.S. Department of Commerce city and County Data Book is a consistent source of data for federal government employment (U.S. Census, 1962C, 1976C, 1972C, 1977C). The base of the relative employment opportunities variable is population. Two data sets provided the population data. The U.S. Census of Population and Housing provide population for 1960 and 1970 (U.S. Census, 1960, 1970a). The state data centers in California, Oregon, and California provide population estimates for the intercensal years. 
The data to calculate unemployment comes from county Business Patterns $(1965,1970 \mathrm{~b}, 1975,1980 \mathrm{~b})$ and U.S. Vital Statistics (U.S. National Center for Health [U.S. Health], $1960,1965,1970,1975)$ data for geographical areas. The unemployment variable is a measure of employment potential. The reported statistical rate of unemployment is not always representative of the degree of unemployment in nonmetropolitan counties. Government data series treat statistics for nonmetropolitan counties as residuals of metropolitan statistics (Briggs, 1981). The National Commission on Employment and Unemployment Statistics in 1979 found the incidence of job scarcity to be higher in nonmetropolitan counties, since the amount of underemployment (involuntarily part-time and discouraged workers) is greater in nonmetropolitan counties (Briggs, 1981). Blanco (1964) and Mazek and Chang (1972) concur from their studies the true unemployment is underreported. Therefore, this study uses "prospective unemployment" as the measure of unemployment. Prospective unemployment is the difference between the natural rate of increase in the population minus the change in the working age population for the three study periods (i.e., 1960-1965, 1965-1970, and 1970-1975). The working age population is defined as the population over the age of 15 and less than the age of 65 . According to Blanco (1964), the change in the working age population should be identical with the changes in 
employment for the five-year interval. This study, therefore, has substituted changes in employment for the working age population, since the exact population figures are not available for the intercensal years. This does not correct all of the problems associated with measuring unemployment levels. At best this measurement is a proxy for unemployment given the problems at both the federal and state level to reliably measure the "real" unemployment rate.

Birth rate data comes from the U.S. National Center for Health Statistics Natality Series and death rates from the U.S. National Center for Health Statistics Mortality series (U.S. Health, 1960, 1965, 1970, 1975). The natural rate of increase is derived by taking the difference between the number of births and deaths in the five-year interval for each of the three periods studied to calculate a five-year growth rate. The employment figures comes from the U.S. Department of Commerce County Business Patterns (U.S. Census, 1965, 1970b, 1975, 1980b). For each period, a five-year growth rate is calculated. The employment potential rate is the difference between the five-year employment growth rate and the five-year growth rate of the natural increase in population.

Federal statistics for Publicly and Privately Owned Utilities in the United States provide data for industrial utility rates (U.S. Energy, 1965, 1970, 1975). The utility 
data, though, are reported by company specific rates. To derive county specific data required obtaining both the public and private utility companies service district maps to make the data specific to the county unit of analysis. When there is more than one utility district in a particular county, a weighted means average was calculated based on the population the district served.

The amenity variables for the labor in- and out-migration equations are calculated also from various data sources: U.S. Census of Population and Housing (U.S. Census, 1960, 1970a, 1980a), Federal Bureau of Irivestigations Crime Reports (U.S. Department of Justice, 1965, 1970, 1975) (as well as state crime reports), public education enrollment for universities and colleges (U.S. Department of Education, 1965, 1970, 1975), state comprehensive outdoor recreation plans (California Department, 1979; Center for Continuing, 1982; Oregon State Highway, 1967; Oregon State Parks, 1983; Washington State Interagency, 1983), and various state recreation agencies. Housing data are acquired from the U.S. Bureau of Census and Population and Housing for the years 1960, 1970, and 1980 (U.S. Census, 1960, 1970a, 1980a). The median dollar value of a housing unit is not available at the county level for the intercensal years. Consequently, the value used in this study for the years 1965 and 1975 represents the midpoint for the 10-year interval. 
The Federal Bureau of Investigations provides data for seven serious crimes, i.e. aggravated assault, burglary, forcible rapes, larceny/theft and motor vehicle theft, murder and manslaughter, and robbery (U.S. Department of Justice, 1965, 1970, 1975). The crime index reported is the number of serious crimes known to police per 100,000 population. The reporting of crime statistics to the U.S. Federal Bureau of Investigations, however, is not mandatory, the reporting is voluntary. As a consequence, it was necessary to supplement the federal data with state crime reports for California, Oregon, and Washington. The state reports contain information on all the counties in the individual states, but do not always report crime statistics annually. For the years when crime data are missing, an average is interpolated based on the interval immediately around the missing data.

The recreational opportunities index is based on calculating a composite factor score index for activity demand and availability of a recreational activity in a county. The data for availability are taken from an inventory of facilities provided in the state county outdoor recreation plans for the states of California (California Department, 1979; Center for Continuing, 1982), Oregon (Oregon State Highway, 1967; Oregon State Parks, 1983), and Washington (Washington State Interagency, 1983). Demand activity data are derived from statistics supplied by the 
state Park and Recreation Departments on usage of campgrounds/picnic tables, hunting and game departments for hunting and fishing license data, and the statistics for Pleasure Boats for the states of California and oregon and Washington's Motor Vehicle Department for pleasure boat usage (Washington state Motor, 1975). The age dependency ratio is calculated based on data collected from the U.S. Census of Population and Housing (U.S. Census, 1960, 1970a, 1998a) and from the population estimates made by the California (California state Census, 1965, 1975), Oregon (Center for Population, 1965, 1975), and Washington (Washington state office, 1983; Washington state Data, 1965, 1975) state data centers. This required making some adjustments to the local populations estimates, because the state data centers' estimation techniques are inconsistent for age estimates in intercensal years. The age distribution data are obtained from the U.S. Census of Population and Housing for the years 1960, 1970, and 1980 (U.S. Census, 1960a, 1970a, 1980a). Therefore, for the years 1965 and 1975, the age distribution data are derived by using the midpoint of the 10-year differences interval. The breakdown of the age distribution then is proportioned according to the state data centers' county estimates for the intercensal years in 1965 and 1975 . The data for the income differences variable also had to be estimated for the intercensal years. The U.S. Census 
of Population and Housing for 1960, 1970, and 1980 provide median income data for individual counties (U.S. Census, 1960, 1970a, 1980a). To obtain county median income for the intercensal years of 1965 and 1975, the midpoint of the 10-year interval is calculated. Since this study's focus is relative differences, median county income is compared to national median income. The relative income differences is the ratio of county median income divided by the median income of the United States. The larger the ratio, the greater the income difference is between the county and the rest of the United States.

\section{CHAPTER SUMMARY AND CONCLUSIONS}

The specified research model described in this chapter is used to investigate the role of economic and noneconomic factors during the nonmetropolitan turnaround. The noneconomic factors that are considered in the research model as environmental amenities are four-year college enrollment, recreational opportunities, education expenditures and income differences. The variables treated as environmental disamenities are adverse climate, age dependency, the proportion of population that is nonwhite, the crime rate and median housing price. The variables used to measure accessibility are the labor potential index, a contiguity variable (moves between adjacent counties), and population size. Employment variables are categorized as 
basic or nonbasic employment opportunities. This

categorization is based on whether a particular economic

activity has above national average employment in a particular industrial sector.

The figure on the following page summarizes the basic relationships to be explored in the data analysis (see Table XVI).

TABLE XVI

THE EXPECTED RELATIONSHIP OF SPECIFIED

VARIABLES WITH LABOR MIGRATION

\begin{tabular}{|c|c|c|c|}
\hline & IN-MIGRATION & OUT-MIGRATION & $\begin{array}{l}\text { EXPECTED } \\
\text { MAGNITUDE }\end{array}$ \\
\hline \multicolumn{4}{|l|}{ Nonadjacent Counties } \\
\hline Amenity & + & - & Large \\
\hline Disamenity & - & + & Small \\
\hline Accessibility & + & + & Large \\
\hline Basic Employment & + & - & Small \\
\hline Nonbasic Employment & + & - & Small \\
\hline \multicolumn{4}{|l|}{ Adjacent counties } \\
\hline Amenity & + & - & Large \\
\hline Disamenity & - & + & Small \\
\hline Accessibility & + & + & Large \\
\hline Basic Employment & + & - & Small \\
\hline Nonbasic Employment & + & - & Small \\
\hline \multicolumn{4}{|l|}{ Metro $<500,000$} \\
\hline Amenity & + & - & Small \\
\hline Disamenity & - & + & Small \\
\hline Accessibility & + & + & Large \\
\hline Basic Employment & + & - & Large \\
\hline Nonbasic Employment & + & - & Large \\
\hline \multicolumn{4}{|l|}{ Metro > 500,000} \\
\hline Amenity & + & - & Small \\
\hline Disamenity & - & + & Large \\
\hline Accessibility & + & + & Large \\
\hline Basic Employment & + & - & Large \\
\hline Nonbasic Employment & + & - & Large \\
\hline
\end{tabular}




\section{CHAPTER V \\ EMPIRICAL RESULTS OF MODEL \\ CALIBRATIONS}

This chapter presents the empirical results from the calibration of the labor migration models. The issues addressed in the chapter are (a) whether there are temporal differences between the pre-turnaround and turnaround models, (b) whether the differences found in the labor migration models are due to population size or proximity to large metropolitan counties, and (c) whether there are differences between labor in-migration and labor out-migration determinants.

The first section of this chapter describes briefly the model selection process for this study. This section discusses which estimation technique (i.e., ordinary least squares or simultaneous equations) is more appropriate for estimating labor migration equations.

The second section discusses the empirical findings of the labor migration equations. The focus of this discussion is on the temporal differences between the pre-turnaround and turnaround models. The research question is whether the observed changes in labor migration flows during the turnaround period represent a clean-break from the pre-turnaround period. 
The third section summarizes whether the response of labor migrants to a county's areal characteristics (i.e., socio-environment amenities, economic activities, and accessibility) varies according to the county's size or proximity to larger metropolitan counties.

The fourth section of this chapter looks at whether or not labor migration to nonmetropolitan counties is a result of a spillover effect from the larger metropolitan counties into their surrounding exurban fringe (i.e., adjacent nonmetropolitan counties). This section attempts to address the argument presented in the recent literature on migration that the nonmetropolitan turnaround really is a function of an expanding urban field (i.e., an extension of metropolitan growth into its immediate hinterland).

MODEL SELECTION

A number of simultaneous estimation techniques are currently available to calibrate such relationships. simultaneous estimation techniques treat individual relationships such as migration and employment as one broad system that contains several subcomponents. The two simultaneous estimation techniques attempted in this study are two stage least squares and three stage least squares. This study finds the two stage least squares model more appropriate than the three stage least squares models 
or the seemingly unrelated equations techniques in estimating labor migration models.

The two stage least squares estimation technique is quite easy to use and has been employed frequently in the scholarly work on population and labor migration in order to control for the causality problems found in modelling migration (Greenwood, 1975, 1981). In the first stage, the two stage least squares estimation technique creates an instrument variable for the endogenous variables (i.e., labor in-migration flows, labor out-migration flows, basic employment and non-basic employment). In the second stage, it replaces the endogenous variables with the estimated fitted variables. This makes it possible to obtain consistent estimators for the employment variables in the migration equations and the migration variables in the employment equations (Pindyck \& Rubinfeld, 1981).

Three stage least squares, on the other hand, has an additional round of estimation (Pindyck \& Rubinfeld, 1981). In the third stage of estimation, the results from the second stage estimation and the residual terms of the individual equations are entered into an additional round of estimation. The purpose of the third stage of estimation is to purge from the overall model any association between the separate equations (i.e., labor in-migration flows, labor out-migration flows, and employment growth equations). 
Recent migration studies show the three stage least squares technique the more appropriate model (Greenwood, 1975, 1981). The contradictory results found in this study is not surprising given the difference in focus of this study with the other studies. Greenwood (1981) examined the structural relationship between migration, employment and income among all the 50 states in the United States which is a closed system. This study examined the response of labor migration flows to different characteristics of individual counties of the three Pacific states, which is not a closed system.

\section{TESTING THE MIGRATION MODEL RESULTS} FOR TEMPORAL CHANGE

The purpose of this study is to determine what factors are behind the turnaround of labor migration in the 1970s. The research question is whether this turnaround is a unique period or simply the accumulation of gradual economic and demographic restructuring. The first set of empirical tests discussed is a comparison of the model results for the three periods studied (1960-1965, 1965-1970, and 1970-1975). These periods are classified as pre-turnaround (1960-1965 and 1965-1970) and turnaround (1970-1975). As described previously, the data are aggregated into four spatially distinct regions: nonadjacent nonmetropolitan (those counties which are not physically adjacent to the large metropolitan counties), adjacent nonmetropolitan (those 
counties which are physically adjacent to the large metropolitan counties), small metropolitan (those counties that are metropolitan with less than 500,000 residents) counties, and large metropolitan (those counties that are metropolitan with greater than 500,000 residents). In this study, the pre-turnaround model is used as a control model to gauge what are the general determinants of labor migration flows at a time when the major destination of labor migrants was metropolitan counties.

The unit of analysis for this study is the interaction of labor migration flows between origin and destination counties in the pacific states of california, oregon, and Washington. As mentioned in chapter IV, nonemployment related moves between counties that are adjacent can be controlled if one eliminates moves of less than 100 miles (Wardwell \& Gilchrist, 1980). For this study, a contiguity variable measures whether a move is from a county which is adjacent to the origin or destination county to see if moving less than 100 miles has a significant influence on labor mobility. If it does not, commuting between the old residence and a new employment location is not a significant issue.

The level of confidence for testing hypotheses in this dissertation is $95 \%$. This confidence level is selected because of the possibility that the labor markets in the 
Pacific states are not completely independent, because there may exist spatial autocorrelation in the model calibrations.

The functional form of the regression models are log linear, with the exception of the contiguity variable. The transformation of the variables into natural logarithm values creates a problem when the value is zero, because the logarithm of zero is undefined. For this study, a constant of 0.5 is added to values that are equal to zero (Fotheringham \& O'Kelly, 1989; Sen \& Soot, 1981).

To test whether the turnaround and pre-turnaround models are identical, a $\underline{F}$ test is used. The $\underline{F}$ test tests whether the coefficients of the different periods are equal. The $\underline{F}$ test not only examines whether the slope and parameters of the temporal models are distinct, but also tests the error structures of the models as well (Pindyck \& Rubinfeld, 1981). All of the spatial models calibrated show the $F$ tests for the turnaround and pre-turnaround models have critical values for the $F$ distribution greater than the $5 \%$ level of significance. Consequently, it is incorrect to assume that the parameter coefficients are equal in the turnaround and pre-turnaround models (refer to Appendix c).

THE NONADJACENT MODELS

Tables XVII-XIX present the breakdown of empirical results for the nonadjacent nonmetropolitan counties. Several of the estimated parameters are opposite of original 
expectations. The labor migration models explain a large proportion of the specified relationships; the $R$ squares for the different periods range from 0.627 to 0.960 .

Table XVII shows the empirical results of the labor migration model for the nonadjacent nonmetropolitan counties. The model results show how environmental amenities, environmental disamenities, accessibility, and employment influence labor migration flows to nonadjacent nonmetropolitan counties.

The influence of the environmental amenity variables on labor in-migration flows to nonadjacent counties is limited. In the 1960-1965 model, just two environmental amenities variables have a significant association with labor in-migration flows: recreational opportunities (a positive coefficient) and educational expenditures (a negative coefficient). There are no significant associations in the 1965-1970 model. In the 1970-1975 model, all of the environmental amenity variables, with the exception of per capita education expenditures, have a positive association with labor in-migration flows. However, only the variable for college enrollment has a significant association at the $95 \%$ confidence level. These results indicate that the amenity preferences for nonadjacent nonmetropolitan counties have not changed substantially since the 1960s. 
TABLE XVII

NONADJACENT COUNTIES LABOR MIGRATION MODEL

\begin{tabular}{|c|c|c|c|c|c|c|c|c|c|c|c|c|}
\hline & \multicolumn{6}{|c|}{ OUT-MIGRATIOH FLOH MOOEL } & \multicolumn{6}{|c|}{ IN-MIGRATION FLOW HOOEL } \\
\hline & \multicolumn{2}{|c|}{$\frac{1960-1965}{1905}$} & \multicolumn{2}{|c|}{$1965-1970$} & \multicolumn{2}{|c|}{$1970-1975$} & \multicolumn{2}{|c|}{$1960-1965$} & \multicolumn{2}{|c|}{$1965-1970$} & \multicolumn{2}{|c|}{$1970-1975$} \\
\hline CONSTANT & 0.207 & 0.089 & 5.466 & 5.550 & 3.935 & 3.492 & 3.372 & 6.945 & 9.190 & 1.686 & 4.571 & 4.427 \\
\hline $\begin{array}{l}\text { EMPLOYMENT ACTIVITY VA } \\
\text { BASIC EMPLOYMENT } \\
\text { NONBASIC EMPLOYMENT }\end{array}$ & $\begin{array}{l}\text { RIABLES } \\
-0.001 \\
-0.026\end{array}$ & $\begin{array}{l}-0.097 \\
-1.137\end{array}$ & $\begin{array}{l}-0.062 \\
-0.005\end{array}$ & $\begin{array}{l}-5.088 \\
-0.980\end{array}$ & $\begin{array}{r}-0.047 \\
0.001\end{array}$ & $\begin{array}{r}-4.409 \\
0.170\end{array}$ & $\begin{array}{r}0.011 \\
-0.004\end{array}$ & $\begin{array}{r}1.340 \\
-0.230\end{array}$ & $\begin{array}{l}-0.003 \\
-0.012\end{array}$ & $\begin{array}{l}-0.109 \\
-0.273\end{array}$ & $\begin{array}{r}-0.002 \\
0.004\end{array}$ & $\begin{array}{r}-0.147 \\
0.189\end{array}$ \\
\hline $\begin{array}{l}\text { ENVIROHMENTAL AMENITIE } \\
\text { COLLEGE } \\
\text { EXPENDITURES } \\
\text { RECREATIOH } \\
\text { INCOHE }\end{array}$ & $\begin{array}{l}0.002 \\
0.007 \\
0.008 \\
0.477\end{array}$ & $\begin{array}{r}0.836 \\
0.862 \\
1.200 \\
-1.607\end{array}$ & $\begin{array}{r}0.001 \\
-0.006 \\
0.009 \\
0.214\end{array}$ & $\begin{array}{r}1.016 \\
-1.848 \\
2.140 \\
1.612\end{array}$ & $\begin{array}{r}-0.005 \\
-0.001 \\
0.002 \\
0.093\end{array}$ & $\begin{array}{r}-0.791 \\
-0.385 \\
0.493 \\
0.568\end{array}$ & $\begin{array}{r}0.001 \\
-0.007 \\
0.009 \\
0.015\end{array}$ & $\begin{array}{r}0.952 \\
-2.792 \\
2.588 \\
0.242\end{array}$ & $\begin{array}{r}0.004 \\
-0.001 \\
0.017 \\
0.343\end{array}$ & $\begin{array}{r}1.250 \\
-0.112 \\
1.286 \\
1.075\end{array}$ & $\begin{array}{r}0.006 \\
-0.002 \\
0.012 \\
0.195\end{array}$ & $\begin{array}{r}1.960 \\
-0.425 \\
1.712 \\
1.464\end{array}$ \\
\hline $\begin{array}{l}\text { ENVIROHMENTAL DISAMENI } \\
\text { AGE DEPENDENCY } \\
\text { UNEMPLOYMENT } \\
\text { NONHHITE } \\
\text { CRIIME } \\
\text { CLIMATE } \\
\text { HOISING }\end{array}$ & $\begin{array}{r}\text { IIES } \\
-0.163 \\
0.002 \\
0.018 \\
0.027 \\
-0.054 \\
0.037\end{array}$ & $\begin{array}{r}-2.118 \\
0.820 \\
2.370 \\
0.726 \\
-1.186 \\
0.890\end{array}$ & $\begin{array}{r}-0.021 \\
0.001 \\
-0.003 \\
0.025 \\
-0.087 \\
-0.028\end{array}$ & $\begin{array}{r}-0.396 \\
1.345 \\
-0.807 \\
4.688 \\
-3.306 \\
-1.310\end{array}$ & $\begin{array}{r}-0.033 \\
-0.000 \\
-0.001 \\
0.040 \\
-0.043 \\
-0.021\end{array}$ & $\begin{array}{r}-0.816 \\
-0.067 \\
-0.100 \\
9.417 \\
-2.140 \\
-1.122\end{array}$ & $\begin{array}{r}-0.110 \\
-0.002 \\
0.003 \\
0.014 \\
-0.008 \\
-0.074\end{array}$ & $\begin{array}{r}-3.069 \\
-2.037 \\
1.169 \\
2.552 \\
-0.478 \\
-3.402\end{array}$ & $\begin{array}{r}0.107 \\
0.001 \\
0.001 \\
0.037 \\
-0.052 \\
0.026\end{array}$ & $\begin{array}{r}0.575 \\
0.225 \\
0.076 \\
1.007 \\
-0.651 \\
0.355\end{array}$ & $\begin{array}{r}0.065 \\
-0.002 \\
-0.001 \\
0.026 \\
-0.025 \\
0.021\end{array}$ & $\begin{array}{r}0.662 \\
-0.835 \\
-0.097 \\
1.354 \\
-0.592 \\
0.511\end{array}$ \\
\hline $\begin{array}{l}\text { ACCESSIBILITY } \\
\text { GRAVITY } \\
\text { COHTIGUOUS } \\
\text { POPULATIOH }\end{array}$ & $\begin{array}{r}0.036 \\
2.336 \\
-0.970\end{array}$ & $\begin{array}{r}10.333 \\
0.790 \\
-24.021\end{array}$ & $\begin{array}{r}0.092 \\
0.900 \\
-1.092\end{array}$ & $\begin{array}{r}10.964 \\
1.521 \\
-53.792\end{array}$ & $\begin{array}{r}0.073 \\
0.200 \\
-1.044\end{array}$ & $\begin{array}{r}7.169 \\
0.359 \\
-55.470\end{array}$ & $\begin{array}{r}0.039 \\
-0.155 \\
-0.992\end{array}$ & $\begin{array}{r}7.371 \\
-0.479 \\
-84.723\end{array}$ & $\begin{array}{r}0.025 \\
5.336 \\
-0.974\end{array}$ & $\begin{array}{r}2.525 \\
1.570 \\
-21.103\end{array}$ & $\begin{array}{r}0.040 \\
2.592 \\
-0.991\end{array}$ & $\begin{array}{r}11.588 \\
1.442 \\
-43.174\end{array}$ \\
\hline $\begin{array}{l}\text { F-VALUE } \\
\text { PROB }> \\
\text { R SOUARE } \\
\text { ADJUSTED R } \\
\text { EXPLAINED SUM SOUARES } \\
\text { ERROR SUM SQUARES }\end{array}$ & $\begin{array}{r}3,565.429 \\
0.000 \\
0.879 \\
0.879 \\
10,351 \\
1,427\end{array}$ & & $\begin{array}{r}7.877 .195 \\
0.000 \\
0.941 \\
0.941 \\
1.0064 \\
628\end{array}$ & & $\begin{array}{r}19.764 .322 \\
0.000 \\
0.960 \\
0.960 \\
10.082 \\
421\end{array}$ & & $\begin{array}{r}17,179.910 \\
0.000 \\
0.972 \\
0.972 \\
17.317 \\
488\end{array}$ & & $\begin{array}{r}828.929 \\
0.000 \\
0.628 \\
0.627 \\
10.297 \\
6103\end{array}$ & & $\begin{array}{r}3,083.090 \\
0.000 \\
0.863 \\
0.862 \\
10.203 \\
1626\end{array}$ & \\
\hline
\end{tabular}

Hotes: 1) Both dependent and independent variables have been transformed into natural logarithm value, except for the contiguous variable. 2) The number of spatial interactions is 7,389 with 7,374 degrees of freedom $(H-15)$.

3) Level of statistical significance is $95 \%$ or $|t| \geq 1.96$. 
TABLE XVIII

NONADJACENT BASIC EMPLOYMENT MODEL

\begin{tabular}{|c|c|c|c|c|c|c|c|c|c|c|c|c|}
\hline & \multicolumn{6}{|c|}{ OUT-MIGRATION FLOW ROOEL } & \multicolumn{6}{|c|}{ IH-MIGRATION FLON MOOEL } \\
\hline & \multicolumn{2}{|c|}{$1960-1965$} & \multicolumn{2}{|c|}{$1965-1970$} & \multicolumn{2}{|c|}{$1970-1975$} & \multicolumn{2}{|c|}{$1960-1965$} & \multicolumn{2}{|c|}{$1965-1970$} & \multicolumn{2}{|c|}{$1970-1975$} \\
\hline & BETA & T for Ho: & BETA & $\mathrm{T}$ for $\mathrm{Ho}:$ & BETA & $T$ for $\mathrm{Ho}:$ & BETA & $T$ for Ho: & BETA & $T$ for Ho: & BETA & T for Ho: \\
\hline CONSTANT & 3.828 & 42.758 & 1.967 & 14.139 & 2.906 & 22.117 & 2.591 & 23.256 & 2.390 & 39.911 & 2.532 & 40.908 \\
\hline \multicolumn{13}{|l|}{ EKOGEROUS VARIABLES } \\
\hline LABOR MIGRATIOH FLOWS & 0.055 & 3.589 & 0.478 & 23.670 & 0.237 & 11.837 & -0.064 & -4.641 & 0.178 & 18.734 & 0.187 & 19.979 \\
\hline NONBASIC EMPLOYMENT & 0.624 & 14.560 & -0.725 & -60.169 & -0.863 & -73.494 & 0.535 & 8.465 & 0.532 & 15.270 & 0.528 & 15.678 \\
\hline \multicolumn{13}{|l|}{ IHDEPENDENT VARIABLES } \\
\hline AGRICULTURAL SERVICES & -0.162 & -9.116 & -0.137 & -4.976 & -0.136 & -5.156 & -0.036 & -1.672 & -0.021 & -1.460 & -0.055 & -3.879 \\
\hline ROUTINE MANUFACTURING & -0.476 & -14.427 & -0.346 & -7.074 & -0.238 & -5.076 & -0.458 & -15.398 & -0.185 & -9.319 & -0.218 & -9.993 \\
\hline PROOUCER & 0.226 & 4.533 & 0.208 & 5.884 & 0.142 & 4.151 & 0.163 & 2.315 & 0.198 & 8.027 & 0.321 & 11.153 \\
\hline ENEREY & -0.401 & -11.767 & -0.068 & -1.333 & 0.006 & 0.113 & 0.152 & 3.998 & -0.194 & -8.564 & -0.238 & -10.207 \\
\hline WAGES & 1.205 & 14.564 & -0.087 & -0.922 & -0.126 & -1.397 & 0.713 & 7.356 & 0.554 & 12.077 & 0.557 & 10.626 \\
\hline FREEWAY & 0.301 & 6.471 & -0.208 & -1.420 & -0.917 & -6.491 & -0.181 & -4.637 & 1.130 & 15.271 & 1.281 & 16.670 \\
\hline F VALUE & 212.190 & & 838.828 & & $1,071.005$ & & 131.624 & & 186.152 & & 220.262 & \\
\hline PROB > & 0.000 & & 0.000 & & 0.000 & & 0.000 & & 0.000 & & 0.000 & \\
\hline R SQUARE & 0.187 & & 0.476 & & 0.537 & & 0.125 & & 0.168 & & 0.193 & \\
\hline ADJUSTED R & 0.186 & & 0.476 & & 0.537 & & 0.124 & & 0.167 & & 0.192 & \\
\hline EXPLAINED SUM SQUARES & 2,356 & & 19,288 & & 22,736 & & 1,387 & & 932 & & 1,152 & \\
\hline ERROR SUM SOUARES & 10,248 & & 21,215 & & 19,586 & & 9,728 & & 4,615 & & 4,824 & \\
\hline
\end{tabular}

Wotes: 1) Both dependent and independent variables have been transformed into natural logarithm value.

2) The number of spatial interactions is 7389 with 7381 degrees of freedom $(\mathrm{N}-8)$.

3) Level of statistical significance is $95 \%$ or $|t| \geq 1.96$. 
TABLE XIX

NONADJACENT NONBASIC EMPLOYMENT MODEL.

\begin{tabular}{|c|c|c|c|c|c|c|c|c|c|c|c|c|}
\hline & \multicolumn{6}{|c|}{ OUT-MIGRATION FLOW MODEL } & \multicolumn{6}{|c|}{ IN-HIGRATION FLON HOOEL } \\
\hline & \multicolumn{2}{|c|}{$1960-1965$} & \multicolumn{2}{|c|}{$1965-1970$} & \multicolumn{2}{|c|}{$1970-1975$} & \multicolumn{2}{|c|}{$1960-1965$} & \multicolumn{2}{|c|}{$1965-1970$} & \multicolumn{2}{|c|}{$1970-1975$} \\
\hline CONSTANT & -9.124 & -9.113 & 2.536 & 8.083 & 5.042 & 18.711 & -0.437 & -4.756 & -0.213 & -2.154 & 1.200 & 9.026 \\
\hline \multicolumn{13}{|l|}{ ENDOGENOUS VARIABLES } \\
\hline LABOR MIGRATION FLOWS & 0.111 & 7.475 & 0.707 & 17.219 & 0.335 & 9.803 & 0.125 & 11.145 & -0.015 & -1.223 & -0.010 & -0.624 \\
\hline SASIC EMPLOYMENT & 0.029 & 2.755 & -1.149 & -61.281 & -1.041 & -72.095 & 0.049 & 2.956 & -0.059 & -3.938 & -0.101 & -6.193 \\
\hline \multicolumn{13}{|l|}{ I HDEPENDENT VARIABLES } \\
\hline \multicolumn{13}{|l|}{ PERSOMAL SERVICES/ } \\
\hline RETAIL & -0.137 & -1.142 & 1.090 & 5.537 & 0.010 & 0.058 & -0.762 & -6.559 & 0.213 & 3.566 & $-\hat{f} .278$ & -10.028 \\
\hline GOVERNMENT & -0.099 & -3.594 & -0.164 & -2.072 & -0.344 & -5.081 & -0.085 & -2.738 & -0.251 & -9.442 & -0.386 & -13.084 \\
\hline RETIREMENT & -0.193 & -7.369 & -0.232 & -2.185 & 0.527 & 5.788 & 0.021 & 0.716 & 0.164 & 6.874 & 0.438 & 16.708 \\
\hline MAGES & -0.352 & -3.422 & -0.464 & -2.572 & 0.210 & 1.363 & 0.582 & 5.703 & -0.715 & -12.886 & 0.494 & 4.445 \\
\hline F VALUE & 224.119 & & 756.336 & & $1,170.291$ & & 56.739 & & 152.757 & & 128.917 & \\
\hline$P R O B=F$ & 0.000 & & 0.000 & & 0.000 & & 0.000 & & 0.000 & & 0.000 & \\
\hline R SOUARE & 0.154 & & 0.381 & & 0.488 & & 0.044 & & 0.119 & & 0.095 & \\
\hline ADJUSTED $R$ & 0.153 & & 0.380 & & 0.487 & & 0.043 & & 0.110 & & 0.094 & \\
\hline EXPLAINED SUIA SOUARES & 731 & & 19867 & & 22496 & & 210 & & 392 & & 388 & \\
\hline ERROR SUM SOUARES & 4,014 & & 32,323 & & 23,653 & & 4,572 & & 3,158 & & 3,706 & \\
\hline
\end{tabular}

Hotes: 1) Both dependenc and independent variables have been transformed into natural logari thm value.

2) The number of spatial interactions is 7,389 with 7,383 degrees of freedom $(\mathrm{N}-6)$.
3) Level of statistical significance is $95 \%$ or $|\mathrm{t}| \geq 1.96$. 
Table XVII shows that the environmental amenity variables have a minor influence on labor out-migration flows in the nonadjacent nonmetropolitan counties. The environmental amenities variables have no significant association with labor out-migration flows in the 1960-1965 and 1970-1975 models. In the 1965-1970 labor out-migration model results, the recreational opportunity variable has a significant and positive association with labor out-migration flows.

The influence of the environmental disamenity variables on labor in-migration flows to the nonadjacent nonmetropolitan counties is limited, if not spurious. In the 1965-1970 and 1970-1975, all of the environmental disamenity variables are insignificant. In the 1960-1965 model, however, the age dependency, unemployment and housing cost variables have the expected significant and negative association with labor in-migration flows. The crime rate variable, on the other hand, has an unexpected significant and positive association with labor in-migration flows in the 1960-1965 model.

Likewise, Table XVII shows that most of the environmental disamenity variables have an insignificant association with labor out-migration flows. However, the crime index variable in the 1965-1970 and 1970-1975 models has the expected significant and positive association with labor out-migration flows. The climate variable has a 
significant and negative association with labor out-migration flows in the 1965-1970 model.

Accessibility as measured by the labor potential index, contiguity, and population size variables has a significant affect on labor migration flows to the nonadjacent nonmetropolitan counties. The labor potential index, which is calculated based on the interaction of the population of the origin and destination counties divided by the distance between the origin and destination counties, has a significant and positive association with labor migration flows. The contiguity variable has no significant influence on either labor migration flows. The population size variable has a significant and negative association with both labor in-migration and out-migration flows. The employment activity variables in Table XVII do not have the expected influence on labor migration flows to the nonadjacent nonmetropolitan counties. Growth in basic employment is insignificantly associated with labor in-migration flows in all three periods. Yet the association between labor out-migration flows and growth in basic employment is as expected in the 1965-1970 and 1970-1975 models (significant and negative). In the 1960-1965 model, the association between labor out-migration and growth in basic employment is insignificant. The role that nonbasic employment growth plays in attracting labor 
migration flows to nonadjacent counties is insignificant in both the labor in-migration and out-migration models.

In sum, Table XVII indicates that labor migration flows may be from the correct origins but not always toward the correct destination. These results are consistent with other research findings on interstate migration flows using the Continuous work History File. Clark's (1983) study of labor migration flows between U.S. states found labor migration flows are from the correct origin states (i.e., states which are not growing), but not always to the correct destination states (states which are growing).

As mentioned previously, several researchers find that labor migration itself influences the basic employment growth (Greenwood, 1975, 1981). The following section focuses on how labor migration flows, economic activities in agricultural services, routine manufacturing and producer services, wage rates, and energy costs influence basic employment growth in nonadjacent nonmetropolitan counties.

Table XVIII shows how labor migration flows influence the growth of basic employment in the nonadjacent nonmetropolitan counties. Contrary to expectations, the 1965-1970 and 1970-1975 nonadjacent nonmetropolitan models show that both labor in-migration and out-migration flows have a positive and significant association with growth in basic employment. In the 1960-1965 model, the association between labor in-migration flows and growth in basic 
employment is just the opposite (negative and significant), but the association between labor out-migration and growth in basic employment is significant and positive.

The scholarly literature suggests that there is a symbiotic relationship between growth in basic employment and nonbasic employment. Table XVIII indicates that this is the case in the nonadjacent counties. Nonbasic employment has a significant and positive influence on basic employment growth in the labor in-migration models. The nonadjacent labor out-migration model results show the opposite association between nonbasic employment growth and basic employment growth (refer to Table XVIII).

The results for the basic employment model support the hypothesis that some scholars have over emphasized manufacturing deconcentration (the spatial filtering of routine, less skilled manufacturing from statistical metropolitan areas to nonmetropolitan counties) as the primary determinant of the nonmetropolitan turnaround. The results for this study show that the employment opportunity variable for routine manufacturing during the turnaround period does not have a positive association with growth in basic employment. It should be noted here that the previous studies which found evidence of spatial filtering focused on geographical areas outside of the Pacific region, such as Erickson's (1976) study which examines spatial filtering in 
the Great Lakes, and Park and Wheeler's (1983) study which examines spatial filtering in Georgia.

The influence of the other employment opportunity variables are more consistent with theoretical expectations. The employment opportunity variable for agricultural services has a significant and negative association with growth in basic employment in the 1970-1975 labor in-migration model. In the other two labor in-migration models (1960-1965 and 1965-1970), the association is insignificant. The association between the employment opportunity variable for agricultural services and growth in basic employment is negative and significant in the labor out-migration models (see Table XVIII).

Regional scholars indicate that service sector activities have had a major influence on growth in basic employment in nonmetropolitan counties during the turnaround period. The employment opportunity variable for producer services has the expected positive and significant relationship with growth in basic employment.

The production input variables in the nonadjacent nonmetropolitan model are inconsistent with the original expectations. The wage rate variable has a positive association with basic employment growth. This result contradicts the least-cost hypothesis for wages which postulates that growth in employment in nonmetropolitan counties is negatively associated with wage rates. 
Industrial energy prices, on the other hand, have the expected significant and negative association with growth in basic employment in the labor in-migration model results (except in the 1960-1965 model). The effect of the energy price variable in the labor out-migration model, however, is minimal.

Access influences growth in basic employment in nonadjacent nonmetropolitan counties. The presence of the interstate highway system (freeway) in a county is used as a measure of access in this dissertation. The freeway variable has a significant and positive association with growth in the 1965-1970 and 1970-1975 labor in-migration models. In the 1960-1965 model, at a time just prior to the completion of the Interstate 5 freeway system in California, oregon, and Washington, the association was significant and negative. The association between growth of basic employment and the freeway variable in the labor out-migration model is negative and significant in all three models (refer to Table XVIII).

Some researchers hypothesize that the influence of labor migration on nonbasic employment growth should be different from its influence on basic employment growth. Table XIX shows the model results for the growth in nonbasic employment in the nonadjacent nonmetropolitan counties. The nonbasic employment model shows some unexpected results. For instance, basic employment growth has an unexpected 
negative association with growth in the nonbasic sectors in the 1965-1970 and 1970-1975 labor in-migration and out-migration models. In the 1960-1965 model, however, the association is positive and significant as expected, while the association is negative and significant in the labor out-migration model.

The labor migration flow variable has not had a major influence on growth in nonbasic employment in the nonadjacent nonmetropolitan counties. On the other hand, the labor out-migration flow variable has the expected negative and significant association with growth in nonbasic employment in the 1965-1970 and 1970-1975 labor out-migration models.

The employment opportunity variables have a significant association with nonbasic employment growth. The employment opportunity variable for personal services and retail has a significant and negative association with nonbasic employment growth in the 1960-1965 and 1970-1975 model calibrations. In the 1965-1970 labor in-migration and out-migration model, the association is positive and significant. The government variable has a negative and significant association with growth in nonbasic employment opportunities in both the labor in-migration and labor out-migration models. What is unexpected is the similarity of association between nonbasic growth and the employment 
opportunity variables in the labor out-migration and labor in-migration models.

The results in Table XIX show evidence for the hypothesis that nonmetropolitan nonbasic employment growth in the early 1970s is related to the influx of retired persons. The presence of population over 65 has a significant association with growth in nonbasic employment in the 1965-1970 and 1970-1975 labor in-migration models, whereas the association between population over 65 and growth in nonbasic employment is insignificant in the 1960-1965 labor in-migration model.

The wage rate variable has a significant influence on growth in nonbasic employment in the nonadjacent nonmetropolitan counties in the labor in-migration model. The wage rate variable has a positive association with growth in nonbasic employment in the 1960-1965 and the 1970-1975 model. In the 1970-1975 labor out-migration model, the association is insignificant. The 1965-1970 labor out-migration and labor in-migration model calibrations show that the wage rate variable has the opposite association with growth in nonbasic employment (negative and significant).

THE ADJACENT NONMETROPOLITAN COUNTIES

Tables XX-XXII show the empirical results for the adjacent nonmetropolitan counties. Like the nonadjacent 
models, several of the parameters in the labor in-migration and out-migration equations are asymmetrical. The models explain a great deal of the specified relationships. The $R$ squares range from 0.781 to 0.953 .

Table Xx displays the results of the labor migration model calibrations for the adjacent nonmetropolitan counties.

The environmental amenity variables have a minor if not spurious influence on the adjacent nonmetropolitan labor migration flows. In the 1970-1975 labor in-migration model, no environmental amenity variable is significant. In the 1965-1970 labor in-migration model, the income differential variable has a significant and negative association with labor in-migration flows. In the 1960-1965 labor in-migration model, the recreational opportunity variable has a significant and positive association with labor in-migration flows and the educational expenditure variable has a significant and negative association with labor in-migration flows.

The influence of the environmental amenity variables on labor out-migration flows in the adjacent nonmetropolitan county models is not significant. None of the environment amenity variables has a significant influence on labor out-migration flows. 
TABLE XX

ADJACENT COUNTIES LABOR MIGRATION MODEL

\begin{tabular}{|c|c|c|c|c|c|c|c|c|c|c|c|c|}
\hline & \multicolumn{5}{|c|}{ OUT-MIGRATION FLOW MODEL } & \multicolumn{7}{|c|}{ IN-MIGRATION FLOW MOOEL } \\
\hline & \multicolumn{2}{|c|}{$1960-1965$} & \multicolumn{2}{|c|}{$1965-1970$} & \multicolumn{2}{|c|}{$1970-1975$} & \multicolumn{2}{|c|}{$1960-1965$} & \multicolumn{2}{|c|}{$1965-1970$} & \multicolumn{2}{|c|}{$1970-1975$} \\
\hline & BETA & $T$ for Ho: & BETA & $T$ for Ho: & BETA & T for Ho: & BETA & $\mathrm{T}$ for Ho: & BETA & $T$ for Ho: & BETA & $T$ for Ho: \\
\hline CONSTANT & 3.123 & 2.045 & 2.337 & 1.261 & 1.732 & 0.830 & 2.430 & 3.348 & -1.574 & -0.796 & 2.275 & 3.076 \\
\hline $\begin{array}{l}\text { EMPLOYMEHT ACTIVITY VARIABLES } \\
\text { BASIC EMPLOYMENT } \\
\text { HONBASIC EMPLOYMENT }\end{array}$ & $\begin{array}{l}-0.006 \\
-0.052\end{array}$ & $\begin{array}{l}-0.905 \\
-3.753\end{array}$ & $\begin{array}{l}-0.003 \\
-0.030\end{array}$ & $\begin{array}{l}-0.077 \\
-1.697\end{array}$ & $\begin{array}{l}-0.047 \\
-0.033\end{array}$ & $\begin{array}{l}-1.583 \\
-2.010\end{array}$ & $\begin{array}{r}0.026 \\
-0.048\end{array}$ & $\begin{array}{r}1.922 \\
-1.714\end{array}$ & $\begin{array}{r}0.003 \\
-0.008\end{array}$ & $\begin{array}{r}0.158 \\
-0.140\end{array}$ & $\begin{array}{l}0.010 \\
0.026\end{array}$ & $\begin{array}{l}0.837 \\
0.575\end{array}$ \\
\hline $\begin{array}{l}\text { ENVIRONMEHTAL AMENITIES } \\
\text { COLLEGE } \\
\text { EXPENDITURES } \\
\text { RECREATION } \\
\text { INCOME }\end{array}$ & $\begin{array}{r}0.002 \\
-0.008 \\
-0.000 \\
-0.029\end{array}$ & $\begin{array}{r}0.493 \\
-1.297 \\
-0.001 \\
-0.133\end{array}$ & $\begin{array}{r}-0.003 \\
-0.012 \\
0.007 \\
0.016\end{array}$ & $\begin{array}{r}-0.641 \\
-1.521 \\
1.115 \\
0.065\end{array}$ & $\begin{array}{r}0.006 \\
-0.008 \\
0.003 \\
-0.171\end{array}$ & $\begin{array}{r}0.564 \\
-1.115 \\
0.416 \\
-0.580\end{array}$ & $\begin{array}{r}0.001 \\
-0.013 \\
0.018 \\
-0.033\end{array}$ & $\begin{array}{r}0.494 \\
-3.237 \\
3.346 \\
-0.341\end{array}$ & $\begin{array}{r}-0.001 \\
-0.008 \\
0.002 \\
-0.666\end{array}$ & $\begin{array}{r}-0.112 \\
-0.602 \\
0.241 \\
-2.599\end{array}$ & $\begin{array}{l}0.003 \\
0.005 \\
0.012 \\
0.085\end{array}$ & $\begin{array}{l}0.443 \\
0.524 \\
1.794 \\
1.156\end{array}$ \\
\hline $\begin{array}{l}\text { ENVIRONMEHTAL DISAMENITIES } \\
\text { AGE DEPENDENCY } \\
\text { UNEMPLOYMENT } \\
\text { NONWHITE } \\
\text { CRIME } \\
\text { CLIMATE } \\
\text { HOUSING }\end{array}$ & $\begin{array}{l}-0.080 \\
-0.001 \\
-0.016 \\
-0.001 \\
-0.023 \\
0.005\end{array}$ & $\begin{array}{l}-0.981 \\
-0.346 \\
-1.974 \\
-0.102 \\
-0.967 \\
0.147\end{array}$ & $\begin{array}{r}-0.160 \\
-0.002 \\
0.012 \\
0.027 \\
0.012 \\
-0.014\end{array}$ & $\begin{array}{r}-1.517 \\
-0.728 \\
0.991 \\
2.850 \\
0.378 \\
-0.349\end{array}$ & $\begin{array}{r}-0.192 \\
-0.002 \\
0.010 \\
0.025 \\
-0.017 \\
-0.070\end{array}$ & $\begin{array}{r}-3.427 \\
-0.846 \\
0.870 \\
3.059 \\
-0.576 \\
-2.176\end{array}$ & $\begin{array}{r}-0.109 \\
-0.000 \\
0.005 \\
0.012 \\
0.004 \\
-0.064\end{array}$ & $\begin{array}{r}-2.149 \\
-0.178 \\
1.321 \\
1.422 \\
0.119 \\
-2.004\end{array}$ & $\begin{array}{r}-0.089 \\
-0.006 \\
0.005 \\
-0.007 \\
-0.005 \\
-0.025\end{array}$ & $\begin{array}{r}-0.488 \\
-1.327 \\
0.205 \\
-0.340 \\
-0.103 \\
-0.362\end{array}$ & $\begin{array}{r}-0.073 \\
-0.004 \\
0.025 \\
0.013 \\
0.073 \\
-0.055\end{array}$ & $\begin{array}{r}-0.541 \\
-1.137 \\
1.367 \\
0.956 \\
1.697 \\
-1.069\end{array}$ \\
\hline $\begin{array}{l}\text { ACCESSIBILITY } \\
\text { GRAVITY } \\
\text { CONTIGUOUS } \\
\text { POPULATION }\end{array}$ & $\begin{array}{r}0.047 \\
-0.294 \\
-1.008\end{array}$ & $\begin{array}{r}7.158 \\
-0.414 \\
-76.943\end{array}$ & $\begin{array}{r}0.043 \\
-0.9647 \\
-0.917\end{array}$ & $\begin{array}{r}1.035 \\
-0.860 \\
-9.891\end{array}$ & $\begin{array}{r}0.052 \\
-1.059 \\
-0.978\end{array}$ & $\begin{array}{r}1.707 \\
-1.096 \\
-13.666\end{array}$ & $\begin{array}{r}0.087 \\
-0.744 \\
-1.028\end{array}$ & $\begin{array}{r}5.314 \\
-1.304 \\
-51.999\end{array}$ & $\begin{array}{r}0.073 \\
-2.318 \\
-1.016\end{array}$ & $\begin{array}{r}5.673 \\
-1.790 \\
-24.281\end{array}$ & $\begin{array}{r}0.077 \\
-1.639 \\
-0.976\end{array}$ & $\begin{array}{r}6.863 \\
-1.482 \\
-36.347\end{array}$ \\
\hline $\begin{array}{l}\text { F-VALUE } \\
\text { PROB }> \\
R \text { SQUARE } \\
\text { ADJUSTED R } \\
\text { EXPLAINED SUA SQUARES } \\
\text { ERROR SUA SQUARES }\end{array}$ & $\begin{array}{r}3077.705 \\
0.000 \\
0.895 \\
0.895 \\
4157 \\
486\end{array}$ & & $\begin{array}{r}822.601 \\
0.000 \\
0.835 \\
0.835 \\
4466 \\
1822\end{array}$ & & $\begin{array}{r}069.167 \\
0.000 \\
0.852 \\
0.852 \\
4508 \\
783\end{array}$ & & $\begin{array}{r}364.278 \\
0.000 \\
0.954 \\
0.953 \\
12709 \\
620\end{array}$ & & $\begin{array}{r}645.400 \\
0.000 \\
0.721 \\
0.720 \\
3109 \\
1205\end{array}$ & & $\begin{array}{r}293.007 \\
0.000 \\
0.782 \\
0.782 \\
4512 \\
1255\end{array}$ & \\
\hline
\end{tabular}

Hotes: 1) Both dependent and independent variables have been transformed into natural logarithm value, except for cont iguous variable. 2) The number of spatial interactions is 5407 with 5397 degrees of freedom $(H-15)$.

3) Level of statistical significance is $95 \%$ or $|t| \geq 1.96$. 
TABLE XXI

\section{ADJACENT COUNTIES BASIC EMPLOYMENT MODEL}

\begin{tabular}{|c|c|c|c|c|c|c|c|c|c|c|c|c|}
\hline & \multicolumn{5}{|c|}{ OUT-MIGRATION FLOM MOOEL } & \multicolumn{7}{|c|}{ IN-MIGRATION FLOH MOOEL } \\
\hline & \multicolumn{2}{|c|}{$1960-1965$} & \multicolumn{2}{|c|}{$1965-1970$} & \multicolumn{2}{|c|}{$1970-1975$} & \multicolumn{2}{|c|}{$1960-1965$} & \multicolumn{2}{|c|}{$1965-1970$} & \multicolumn{2}{|c|}{$1970-1975$} \\
\hline & BETA & I TOr HO: & BEIA & T tor ho: & BEIA & I tor $\mathrm{HO}:$ & BETA & I for Ho: & BEIA & I tor ho: & BEIA & I tor no: \\
\hline COHSTAHT & 2.576 & 12.187 & 1.511 & 3.805 & 1.544 & 4.550 & 2.620 & 20.323 & 0.674 & 2.030 & 1.789 & 6.290 \\
\hline \multicolumn{13}{|l|}{ EXOGENOUS VARIABLES } \\
\hline LABOR MIGRATION FLOWS & -0.190 & -7.783 & 0.113 & 2.387 & 0.001 & 0.026 & -0.063 & -3.951 & -0.184 & -4.815 & -0.168 & -5.498 \\
\hline NOHBASIC EMPLOYMENT & 0.275 & 7.317 & -0.780 & -60.168 & -0.815 & -65.199 & 0.565 & 7.733 & -0.780 & -10.667 & -0.611 & -9.350 \\
\hline \multicolumn{13}{|l|}{ INDEPENDENT VARIABLES } \\
\hline AGRICULTURAL SERVICES & -0.333 & -14.431 & -0.128 & -4.955 & -0.113 & -4.294 & -0.033 & -1.317 & -0.610 & -15.012 & -0.583 & -16.661 \\
\hline ROUTINE MANUFACTURING & -0.292 & -11.433 & -0.209 & -6.145 & -0.232 & -6.513 & -0.460 & -13.163 & -0.037 & -1.037 & -0.031 & -1.016 \\
\hline PROOUCER & 0.299 & 6.038 & 0.075 & 1.032 & -0.042 & -0.475 & 0.160 & 1.949 & 0.468 & 4.932 & 0.556 & 6.787 \\
\hline ENERGY & 0.911 & 17.045 & -0.249 & -3.731 & -0.019 & -0.288 & 0.141 & 3.183 & 0.849 & 12.378 & 1.030 & 16.753 \\
\hline HAGES & 1.128 & 18.163 & -0.168 & -1.882 & 0.087 & 1.053 & 0.723 & 6.365 & 0.245 & 2.778 & 0.458 & 6.215 \\
\hline FREEUAY & 0.510 & 12.696 & 0.257 & 4.545 & 0.216 & 2.352 & -0.171 & -3.801 & 0.406 & 4.559 & 0.474 & 6.447 \\
\hline F VALUE & 363.837 & & 760.535 & & 808.475 & & 92.216 & & 90.551 & & 147.887 & \\
\hline PROB > & 0.000 & & 0.000 & & 0.000 & & 0.000 & & 0.000 & & 0.000 & \\
\hline R SOUARE & 0.350 & & 0.530 & & 0.545 & & 0.125 & & 0.162 & & 0.180 & \\
\hline AD JUSTED R & 0.349 & & 0.529 & & 0.544 & & 0.124 & & 0.160 & & 0.179 & \\
\hline EXPLAINED SUM SQUARES & 3,718 & & 13,060 & & 14,090 & & 1,019 & & 5,824 & & 1,793 & \\
\hline ERROR SUA SOUARES & 6,897 & & 11,589 & & 11,761 & & 7,152 & & 5,204 & & 8,183 & \\
\hline
\end{tabular}

Notes: 1) Both dependent and independent variables have been transformed into natural logarithm value.

2) The number of spatial interactions is 5,407 with 5,399 degrees of freedom $(\mathrm{H}-8)$. 
TABLE XXII

ADJACENT NONBASIC EMPLOYMENT MODEL

\begin{tabular}{|c|c|c|c|c|c|c|c|c|c|c|c|c|}
\hline & \multicolumn{6}{|c|}{ OUT-MIGRATION FLON MOOEL } & \multicolumn{6}{|c|}{ IN-MIGRATION FLOW MOOEL } \\
\hline & \multicolumn{2}{|c|}{$1960-1965$} & \multicolumn{2}{|c|}{$1965-1970$} & \multicolumn{2}{|c|}{$1970-1975$} & \multicolumn{2}{|c|}{$1960-1965$} & \multicolumn{2}{|c|}{$1965-1970$} & \multicolumn{2}{|c|}{$1970-1975$} \\
\hline & BETA & $T$ for Ho: & BETA & $T$ for Ho: & BETA & $T$ for Ho: & BETA & $T$ for Ho: & BETA & $T$ for Ho: & BETA & $T$ for Ho: \\
\hline CONSTANT & -1.272 & -9.458 & 2.301 & 7.024 & 2.710 & 8.570 & -0.459 & -4.258 & -0.093 & -0.711 & 0.339 & 3.072 \\
\hline \multicolumn{13}{|l|}{ ENDOGENOUS VARIABLES } \\
\hline$\overline{\text { LABOR MIGRATION FLOWS }}$ & 0.169 & 10.599 & 0.148 & 3.587 & 0.057 & 1.480 & 0.123 & 9.260 & 0.034 & 2.081 & -0.006 & -0.466 \\
\hline BASIC EMFLOYMEAT & 0.115 & 10.110 & -1.140 & -60.308 & -1.122 & -65.523 & 0.056 & 2.892 & 0.034 & 2.337 & 0.094 & 7.688 \\
\hline \multicolumn{13}{|l|}{ INDEPENDENT VARIABLES } \\
\hline PERSONAL SERVICES/RETAIL & -1.181 & -6.738 & -0.236 & -1.174 & -0.009 & -0.044 & -0.715 & -5.242 & 0.153 & 1.562 & 0.227 & 2.714 \\
\hline GOVERNMENT & -0.703 & -18.351 & -0.321 & -3.439 & -0.145 & -1.596 & -0.086 & -2.380 & -0.494 & -12.712 & -0.331 & -10.146 \\
\hline RETIREMEHT & -0.601 & -14.261 & -0.007 & -0.075 & 0.037 & 0.409 & 0.017 & 0.495 & -0.187 & -4.823 & -0.124 & -3.809 \\
\hline HAGES & 0.990 & 6.782 & 0.693 & 3.776 & 0.602 & 3.349 & 0.537 & 4.477 & 0.134 & 1.533 & 0.164 & 2.193 \\
\hline f VALUE & 126.930 & & 1015.905 & & 149.350 & & 41.904 & & 72.928 & & 148.330 & \\
\hline $\mathrm{PROB}>F$ & 0.000 & & 0.000 & & 0.000 & & 0.000 & & 0.000 & & 0.000 & \\
\hline R SQUARE & 0.124 & & 0.530 & & 0.561 & & 0.045 & & 0.104 & & 0.142 & \\
\hline ADJUSTED $R$ & 0.123 & & 0.530 & & 0.560 & & 0.043 & & 0.103 & & 0.140 & \\
\hline EXPLAINED SUM SQUARES & 385 & & 18682 & & 20813 & & 154 & & 162 & & 337 & \\
\hline ERROR SUM SOUARES & 2731 & & 16553 & & 15808 & & 3326 & & 72 & & 2045 & \\
\hline
\end{tabular}

Hotes: 1) Both dependent and independent variables have been transformed into natural logarithm value.

2) The number of spatial interactions is 5407 with 5401 degrees of freedom $(\mathrm{H}-6)$.

3) Level of statistical significance is $95 \%$ or $|t| \geq 1.96$. 
The environmental disamenity variables have a limited influence on the adjacent nonmetropolitan labor migration flows. In the 1970-1975 model, three of the environmental disamenity variables show the expected negative association with labor in-migration flows (age dependency, unemployment, and average housing prices). Two of the environmental disamenity variables (age dependency and climate) have a significant influence on labor in-migration flows in the 1960-1965 labor in-migration model (refer to Table XX). Table XVI shows that the influence of the environmental disamenity variables on labor out-migration flows to the adjacent nonmetropolitan counties is limited. The crime rate variable has a significant and positive association with labor out-migration flows in the 1965-1970 and 1970-1975 models. The proportion of nonwhite population has an unexpected positive and significant association with labor out-migration.

Accessibility (as measured by the labor potential index, contiguity, and population size variables) is a major factor in explaining labor migration flows to adjacent nonmetropolitan counties. The labor potential index has a significant association with both labor in-migration and labor out-migration flows. Population size has a significant, negative association with labor migration flows. The effect of movement between contiguity counties has a significant negative effect on labor in-migration 
flows in the 1960-1965 and 1965-1970 model calibrations. In the 1970-1975 model calibrations, the association between the contiguity county variable and labor in-migration flows is insignificant. The association between the contiguity variables and labor out-migration flows is insignificant.

The economic activity variables have an insignificant influence on labor migration flows to the adjacent nonmetropolitan counties. Just in the 1960-1965 labor out-migration model is the association between the employment growth variables and labor out-migration significant.

Table XXI displays the results for calibrating the basic employment model which examines the influence of labor migration flows, growth in nonbasic employment, employment opportunities in agricultural services, routine manufacturing, producer services, industrial energy rates, and wage rates on growth in basic employment in the adjacent noninetropolitan counties.

The influence of labor migration flows on basic employment growth in adjacent nonmetropolitan counties is not as expected. The 1960-1965 basic employment model shows the labor in-migration flow variable has no significant influence on basic employment growth. Whereas, in the 1965-1970 and 1970-1975 model calibrations, the association between the labor in-migration flow variable and growth in basic employment is significant and negative. The 
association between the labor out-migration flow variable and growth in basic employment is the opposite, positive and significant in all three model calibrations (refer to Table $\mathrm{XXI)}$.

The influence of growth in nonbasic employment on growth in basic employment is not always as expected. In the 1960-1965 and 1970-1975 basic employment model, growth in nonbasic employment, has had a significant and positive association with growth in basic employment in the labor in-migration model. Yet in the 1965-1970 labor in-migration model, growth in nonbasic employment has a negative and significant association with growth in basic employment.

The results for the labor out-migration model are more consistent with the expected outcomes, growth in nonbasic employment has a significant and negative association with growth in basic employment in the 1965-1970 and 1970-1975 out-migration model. However, in the 1960-1965 labor out-migration model, the association is the opposite.

Table XXI shows several unexpected associations between growth in basic employment and the employment opportunity variables. The association between the employment opportunity variable for agricultural services and growth in basic employment is negative and significant in most of the labor migration models. The employment opportunity variable for routine manufacturing has a negative association with growth in basic employment in the 
1970-1975 and 1960-1965 labor in-migration models and a positive association with growth in basic employment in the 1965-1970 labor in-migration model.

The relationship between the employment opportunity variables and basic employment growth in Table XXI is as expected in the labor out-migration calibrations. In the labor out-migration models, the employment opportunity variables for routine manufacturing and agricultural services have a significant and negative association with growth in basic employment in all three model calibrations.

The hypothesis that not enough attention has been paid to the role services play in adjacent nonmetropolitan counties is supported in the model results. The association between the employment opportunity variable for producer services and growth in basic employment is positive and significant. However, the association between the producer service variable and growth in basic employment in the labor out-migration model is spurious in Table XXI.

The parameter results for the cost variables as measured by energy prices and wage rates is not consistent with original expectations in the adjacent nonmetropolitan counties over time. The energy price variable shows a positive and significant association with growth in basic employment in both the labor in-migration and labor out-migration models. The wage rate variable, as well, has a significant and positive influence on growth in basic 
employment in the adjacent nonmetropolitan counties in the labor in-migration models. The labor out-migration model results also show an inconsistent relationship between the cost variables and growth in basic employment.

The model results for the adjacent nonmetropolitan counties make it difficult to determine whether the nonmetropolitan growth in basic employment in the early 1970 s in the Pacific states is a result of a de-industrialization process which led to a filtering of traditional basic economic activity (i.e., routine manufacturing and agriculture) from nearby metropolitan regions to their adjacent nonmetropolitan fringe.

Table XXII displays the results of the calibration for the adjacent nonmetropolitan nonbasic employment model.

The association between labor migration flows and growth in nonbasic employment in the adjacent nonmetropolitan counties is consistent with theoretical expectations. The labor in-migration flow variable has a positive and significant association with growth in nonbasic employment. The labor out-migration variable has a limited association with growth in nonbasic employment.

The association between growth in basic employment and nonbasic employment is as expected in the adjacent county model. Growth in basic employment has a positive and significant association with norbasic employment growth in the labor in-migration models. In the labor out-migration 
models, the association is negative and significant, except in the 1960-1965 model.

There are several unexpected associations between the employment opportunity variables and nonbasic employment growth in the smaller metropolitan county model results. In most of the labor in-migration models, the employment opportunity variables have a negative and significant association with nonbasic employment growth. In the labor out-migration models, the personal services and the retail trade variable has an insignificant association with nonbasic employment growth (refer to Table XXII).

The other variables in the nonbasic employment model show contradictory results in the smaller metropolitan county model results. The wage rate variable shows an unexpected positive and significant association with growth in nonbasic employment, except in the 1965-1970 model. Contrary to expectations, the retirement variable has a negative and significant association with nonbasic employment in both the labor out-migration and labor in-migration models except in the 1960-1965 labor in-migration model.

\section{SMALLER METROPOLITAIN COUNTY MODEL RESULTS}

The following section analyzes the empirical results of the smaller metropolitan county models (those counties that are metropolitan, but have a population less than 
500,000). Tables XXIII-XXV display the empirical results for the smaller metropolitan county calibrations. The smaller metropolitan labor migration models explain a medium to large proportion of the specified relationship. The $R$ squares range from 0.351 to 0.840 .

Table XXIII displays the results of the calibration of the smaller metropolitan labor migration flow models.

The environmental amenity variables do not have a major influence on labor in-migration flows to the smaller metropolitan counties. Just one of the environmental amenities variables, the recreational opportunities, has a positive and significant affect on labor migration in the 1970-1975 model. None of the environmental variables have a significant association with labor out-migration.

only a few of the environmental disamenities variables have the expected negative association with labor in-migration flows in the smaller metropolitan counties. The crime rate variable has the expected significant and negative association with labor in-migration, whereas age dependency, climate, and the housing variables have an unexpected significant and positive association with labor in-migration flows in the 1970-1975 model. In the 1965-1970 model, just the climate variable has a significant association with labor in-migration (the coefficient is positive). In the 1960-1965 model, the age dependency and climate variables have the expected negative and significant 
TABLE XXIII

METRO $<500,000$ COUNTIES LABOR MIGRATION MODEL

\begin{tabular}{|c|c|c|c|c|c|c|c|c|c|c|c|c|}
\hline & \multicolumn{5}{|c|}{ OUT-HIGRATIOH FLOW HODEL } & \multicolumn{7}{|c|}{ IN-MIGRATION FLOW MOOEL } \\
\hline & \multicolumn{2}{|c|}{$1960-1965$} & \multicolumn{2}{|c|}{$1965-1970$} & \multicolumn{2}{|c|}{$1970-1975$} & \multicolumn{2}{|c|}{$1960-1965$} & \multicolumn{2}{|c|}{$1965-1970$} & $1970-1975$ & $\frac{-19 \overline{75}}{T \text { for Ho: }}$ \\
\hline CONSTANT & $-0.4 \pi$ & -0.054 & -1.190 & -0.163 & 7.986 & 0.667 & 4.561 & 1.939 & 0.070 & 0.020 & -2.859 & -0.820 \\
\hline $\begin{array}{l}\text { EMPLOYMENT VARIABLES } \\
\text { BASIC EMPLOYHENT } \\
\text { MONBASIC EMPLOYMENT }\end{array}$ & $\begin{array}{r}0.151 \\
-0.023\end{array}$ & $\begin{array}{r}0.390 \\
-0.225\end{array}$ & $\begin{array}{r}-0.104 \\
0.013\end{array}$ & $\begin{array}{r}-1.323 \\
0.498\end{array}$ & $\begin{array}{r}-0.102 \\
0.005\end{array}$ & $\begin{array}{r}-0.943 \\
0.109\end{array}$ & $\begin{array}{r}0.019 \\
-0.266\end{array}$ & $\begin{array}{r}0.726 \\
-4.322\end{array}$ & $\begin{array}{r}0.089 \\
-0.030\end{array}$ & $\begin{array}{r}0.159 \\
-0.208\end{array}$ & $\begin{array}{l}0.002 \\
0.007\end{array}$ & $\begin{array}{l}0.004 \\
0.056\end{array}$ \\
\hline $\begin{array}{l}\text { ENVIRONMENTAL AMENITIES } \\
\text { COLLEGE } \\
\text { EXPENDITURES } \\
\text { RECREATION } \\
\text { INCOME }\end{array}$ & $\begin{array}{r}0.022 \\
-0.001 \\
0.020 \\
0.418\end{array}$ & $\begin{array}{r}1.144 \\
-0.041 \\
0.712 \\
0.288\end{array}$ & $\begin{array}{r}0.005 \\
0.005 \\
-0.003 \\
-0.213\end{array}$ & $\begin{array}{r}1.156 \\
0.206 \\
-0.122 \\
-0.201\end{array}$ & $\begin{array}{r}0.002 \\
-0.027 \\
-0.014 \\
1.223\end{array}$ & $\begin{array}{r}0.127 \\
-0.731 \\
-0.541 \\
0.695\end{array}$ & $\begin{array}{r}0.008 \\
-0.025 \\
0.038 \\
0.183\end{array}$ & $\begin{array}{r}1.681 \\
-2.925 \\
3.168 \\
0.580\end{array}$ & $\begin{array}{r}0.021 \\
-0.013 \\
0.025 \\
0.657\end{array}$ & $\begin{array}{r}0.738 \\
-0.537 \\
0.962 \\
0.859\end{array}$ & $\begin{array}{r}0.013 \\
-0.014 \\
0.035 \\
0.186\end{array}$ & $\begin{array}{r}0.541 \\
-0.687 \\
1.545 \\
0.670\end{array}$ \\
\hline $\begin{array}{l}\text { ENVIRONMENTAL DISAMENITIES } \\
\text { AGE DEPENDENCY } \\
\text { UNEMPLOYMENT } \\
\text { NOKHHITE } \\
\text { CRIME } \\
\text { CLIMATE } \\
\text { HOUSING }\end{array}$ & $\begin{array}{l}0.241 \\
0.012 \\
0.105 \\
0.008 \\
0.495 \\
0.153\end{array}$ & $\begin{array}{l}0.309 \\
0.647 \\
0.784 \\
0.168 \\
1.422 \\
0.442\end{array}$ & $\begin{array}{l}0.270 \\
0.000 \\
0.052 \\
0.028 \\
0.135 \\
0.110\end{array}$ & $\begin{array}{l}0.904 \\
0.001 \\
1.056 \\
0.684 \\
1.113 \\
1.122\end{array}$ & $\begin{array}{r}0.265 \\
-0.002 \\
0.122 \\
-0.065 \\
0.230 \\
0.055\end{array}$ & $\begin{array}{r}0.610 \\
-0.229 \\
1.454 \\
-0.978 \\
1.220 \\
0.377\end{array}$ & $\begin{array}{r}-0.325 \\
-0.001 \\
0.017 \\
0.017 \\
-0.172 \\
-0.010\end{array}$ & $\begin{array}{r}-2.585 \\
-0.313 \\
0.709 \\
0.691 \\
-3.495 \\
-0.137\end{array}$ & $\begin{array}{r}0.294 \\
0.011 \\
0.151 \\
-0.009 \\
0.498 \\
0.221\end{array}$ & $\begin{array}{r}0.426 \\
0.378 \\
1.169 \\
-0.170 \\
1.280 \\
0.551\end{array}$ & $\begin{array}{r}0.771 \\
0.011 \\
0.124 \\
-0.027 \\
0.525 \\
0.390\end{array}$ & $\begin{array}{r}1.303 \\
0.425 \\
1.121 \\
-0.591 \\
1.561 \\
1.133\end{array}$ \\
\hline $\begin{array}{l}\text { ACCESSIBILITY } \\
\text { GRAVITY } \\
\text { CONTIGUOUS } \\
\text { POPULATIOH }\end{array}$ & $\begin{array}{r}0.190 \\
-2.712 \\
-1.022\end{array}$ & $\begin{array}{r}1.501 \\
-0.340 \\
-16.969\end{array}$ & $\begin{array}{r}0.232 \\
2.284 \\
-1.154\end{array}$ & $\begin{array}{r}3.880 \\
1.218 \\
-9.216\end{array}$ & $\begin{array}{r}0.277 \\
-2.549 \\
-1.218\end{array}$ & $\begin{array}{r}3.318 \\
-0.744 \\
-6.592\end{array}$ & $\begin{array}{r}0.073 \\
0.958 \\
-0.968\end{array}$ & $\begin{array}{r}1.890 \\
1.085 \\
-15.813\end{array}$ & $\begin{array}{r}0.230 \\
-4.059 \\
-1.022\end{array}$ & $\begin{array}{r}2.454 \\
-0.690 \\
-14.249\end{array}$ & $\begin{array}{r}0.244 \\
-3.063 \\
-1.066\end{array}$ & $\begin{array}{r}2.863 \\
-0.606 \\
-17.386\end{array}$ \\
\hline $\begin{array}{l}\text { F-VALUE } \\
\text { PROB }> \\
R \text { SQUARE } \\
\text { ADJUSTED R } \\
\text { EXPLAINED SUM SOUARES } \\
\text { ERROR SUM SOUARES }\end{array}$ & $\begin{array}{r}169.006 \\
0.000 \\
0.533 \\
0.530 \\
1591 \\
1395\end{array}$ & & $\begin{array}{r}34.616 \\
0.000 \\
0.699 \\
0.697 \\
1676 \\
723\end{array}$ & & $\begin{array}{r}152.297 \\
0.000 \\
0.507 \\
0.503 \\
1598 \\
1556\end{array}$ & & $\begin{array}{r}214.745 \\
0.000 \\
0.891 \\
0.891 \\
299.374 \\
524.763\end{array}$ & & $\begin{array}{r}104.523 \\
0.000 \\
0.413 \\
0.409 \\
1589 \\
2256\end{array}$ & & $\begin{array}{r}151.291 \\
0.000 \\
0.505 \\
0.502 \\
1691 \\
1659\end{array}$ & \\
\hline
\end{tabular}

Wotes: 1) Both dependent and independent variables have been transformed into natural logarithm value, except for cont isuous variable.

2) The number of spatial interactions is 2239 with 2224 degrees of freedon $(H-15)$.

3) Level of statistical significance is $95 \%$ or $|t| \geq 1.96$ amenities. 
TABLE XXIV

METRO < 500,000 BASIC EMPLOYMENT MODEL

\begin{tabular}{|c|c|c|c|c|c|c|c|c|c|c|c|c|}
\hline & \multicolumn{5}{|c|}{ OUT-MIGRATION FLOW MOOEL } & \multicolumn{7}{|c|}{ IN-MIGRATION FLCW MOOEL } \\
\hline & $1960-1965$ & $\frac{1965}{T \text { for Ho: }}$ & $1965-1970$ & T for Ho: & $1970-1975$ & $\frac{1975}{\mathrm{~T} \text { for } \mathrm{Ho}}$ & \multicolumn{2}{|c|}{$1960-1965$} & $\frac{1965}{\text { BETA }}$ & $\frac{-1970}{T \text { for Ho: }}$ & $1970-1975$ & $\frac{-1975}{T \text { for Ho: }}$ \\
\hline CONSTANT & 3.739 & 63.303 & 3.765 & 5.604 & 5.883 & 11.075 & 2.829 & 13.763 & 1.931 & 35.499 & 2.182 & 20.304 \\
\hline \multicolumn{13}{|l|}{ ENDOGENOUS VARIABLES } \\
\hline LABOR MIGRATION FLOWS & 0.102 & 12.179 & 0.627 & 6.654 & 0.557 & 7.052 & -0.062 & -2.114 & 0.096 & 13.990 & 0.082 & 1.138 \\
\hline NONBASIC EMPLOYMENT & 0.021 & 1.621 & -0.509 & -19.720 & -0.590 & -29.669 & 0.645 & 6.361 & -0.027 & -2.332 & -0.026 & 16.299 \\
\hline \multicolumn{13}{|l|}{ I NDEPENDENT VARIABLES } \\
\hline AGRICULTURAL SERVICES & 0.215 & 20.450 & 0.175 & 2.392 & 0.220 & 3.501 & -0.040 & -0.966 & 0.311 & 30.631 & 0.311 & 5.928 \\
\hline ROUTINE MANUFACTURING & 0.691 & 19.183 & 1.320 & 7.600 & 1.510 & 10.490 & -0.510 & -9.274 & 1.021 & 28.504 & 0.997 & -0.814 \\
\hline NONROUTINE MANUFACTURIHG & -0.091 & -9.317 & -0.201 & -3.441 & -0.234 & -4.667 & 0.274 & 1.993 & -0.132 & -17.854 & -0.133 & 2.859 \\
\hline PROOUCER & 1.017 & 29.820 & 1.205 & 6.625 & 1.414 & 8.963 & 0.135 & 1.058 & 1.100 & 38.686 & 1.083 & 6.062 \\
\hline ENERGY & 0.434 & 17.515 & 0.788 & 5.085 & 0.928 & 7.213 & 0.132 & 1.858 & 0.558 & 24.341 & 0.550 & 5.241 \\
\hline WAGES & -2.090 & -27.266 & -3.358 & -8.764 & -3.724 & -11.356 & 0.823 & 4.747 & -2.578 & -36.246 & -2.525 & -4.232 \\
\hline FREEWAY & -0.276 & -28.821 & -0.129 & -1.586 & -0.140 & -2.184 & -0.102 & -1.520 & -0.319 & -36.147 & -0.308 & -18.055 \\
\hline F VALUE & 551.154 & & 181.433 & & 297.131 & & 36.427 & & 734.482 & & 741.782 & \\
\hline PROB > & 0.000 & & 0.000 & & 0.000 & & 0.000 & & 0.000 & & 0.000 & \\
\hline R SOUARE & 0.690 & & 0.423 & & 0.545 & & 0.128 & & 0.748 & & 0.749 & \\
\hline ADJUSTED $R$ & 0.689 & & 0.420 & & 0.544 & & 0.125 & & 0.747 & & 0.748 & \\
\hline EXPLAINED SUM SQUARES & 162 & & 3789 & & 4421 & & 456.142 & & 176 & & 175 & \\
\hline ERROR SUM SOUARES & 73 & & 5175 & & 3686 & & 3102.715 & & 59 & & 58 & \\
\hline
\end{tabular}

Hotes: 1) Both dependent and independent variables have been transformed into natural logari thm value.

2) The number of spatial interactions is 2239 with 2230 degrees of freedom $(\mathrm{N}-9)$.

3) Level of statistical significance is $95 \%$ or $|t| \geq 1.96$. 
TABLE XXV

METRO < 500,000 NONBASIC EMPLOYMENT MODEL

\begin{tabular}{|c|c|c|c|c|c|c|c|c|c|c|c|c|}
\hline & \multicolumn{5}{|c|}{ OUT-MIGRATION FLOW MOOEL } & \multicolumn{7}{|c|}{ IN-MIGRATIOH FLOW HOOEL } \\
\hline & $1900-1965$ & $\frac{-1965}{T \text { for Ho: }}$ & $1965-1970$ & $\frac{-1970}{T \text { for Ho: }}$ & \multicolumn{2}{|c|}{$1970-1975$} & \multicolumn{2}{|c|}{$1960-1965$} & \multicolumn{2}{|c|}{$1965-1970$} & $\frac{1970-1}{\text { BETA }}$ & $\frac{975}{T \text { for Ho: }}$ \\
\hline CONSTANT & -3.746 & -19.889 & 5.569 & 2.287 & 7.188 & 4.488 & -0.850 & -5.158 & -0.253 & -1.545 & -0.176 & -1.090 \\
\hline \multicolumn{13}{|l|}{ ENDOGENOUS VARIABLES } \\
\hline LAEOR MIGRATIOH FLOWS & 0.090 & 2.881 & 1.501 & 3.040 & 1.007 & 3.298 & 0.049 & 2.497 & 0.107 & 3.662 & 0.062 & 2.325 \\
\hline BASIC EMPLOYHEKT & 1.331 & 38.151 & -1.935 & -12.252 & -1.616 & -20.239 & 0.102 & 3.664 & 1.332 & 38.411 & 1.333 & 38.641 \\
\hline \multicolumn{13}{|l|}{ INDEPENDENT VARIABLES } \\
\hline PERSONAL SERVICES/RETAIL & -1.293 & -3.902 & -0.758 & -0.321 & -0.315 & -0.182 & 0.377 & 3.629 & -1.533 & -4.469 & -1.578 & -4.461 \\
\hline GOVERKHENT & 0.145 & 3.719 & -0.150 & -0.516 & -0.051 & -0.291 & -0.181 & -3.371 & 0.118 & 2.930 & 0.118 & 2.836 \\
\hline RETIREMENT & 0.032 & 0.443 & -1.719 & -2.314 & -1.271 & -2.574 & 0.000 & 0.005 & 0.019 & 0.272 & 0.117 & 1.769 \\
\hline WAGES & 1.266 & 3.637 & 1.683 & 0.632 & 1.149 & 0.593 & -0.432 & -4.464 & 1.533 & 4.287 & 1.508 & 4.096 \\
\hline F VALUE & 292.701 & & 147.437 & & 296.248 & & 18.691 & & 293.670 & & 294.296 & \\
\hline$P R O B>F$ & 0.000 & & 0.000 & & 0.000 & & 0.000 & & 0.000 & & 0.000 & \\
\hline$R$ SQUARE & 0.440 & & 0.284 & & 0.443 & & 0.048 & & 0.441 & & 0.441 & \\
\hline ADJUSTED $R$ & 0.439 & & 0.282 & & 0.442 & & 0.045 & & 0.439 & & 0.440 & \\
\hline EXPLAIMED SUM SOUARES & 426 & & 8169 & & 8341 & & 66.407 & & 427 & & 426 & \\
\hline ERROR SUM SQUARES & 542 & & 20621 & & 296 & & 1322.258 & & 542 & & 294 & \\
\hline
\end{tabular}

Hotes: 1) Both dependent and independent variables have been transformed into natural logarithm values.

2) Number of spatial interactions 2239 with 2233 degrees of freedom (N-6).

3) Level of statistical significance is $95 \%$ or $|t| \geq 1.96$. 
association with labor in-migration. The environmental disamenity variables have a limited influence on labor out-migration. In the 1970-1975 model, both the variables for percentage of the population nonwhite and climate have the expected significant and positive association with labor out-migration flows. In the 1965-1970 model, the variable for percentage nonwhite has the expected significant and positive association with labor out-migration. In the 1960-1965 model, none of the environmental disamenity variables has a significant association with labor out-migration flows.

The accessibility variables have a major influence on labor migration to the smaller metropolitan counties. The labor potential index has a significant association with labor migration. The effect of a county being contiguous is insignificant. The association between population size and labor migration flows is negative and significant.

Basic employment does not have a significant influence on labor migration flows in the smaller metropolitan county models. Nor does nonbasic employment growth have a significant influence on labor migration flows.

Table XXIV displays the results of the model calibration for growth in basic employment in the smaller metropolitan counties.

The labor in-migration flow variable does not have a significant influence on basic employment growth in the 
smaller metropolitan counties, except in the 1965-1970 model. However, the labor out-migration flow variable has an unexpected positive and significant influence on growth in basic employment.

In the smaller metropolitan counties, there is a symbiotic relationship between nonbasic employment growth and basic employment growth. In the labor in-migration models, nonbasic employment growth has a positive and significant influence on basic employment growth (except in the 1965-1970 model). In the labor out-migration models, the association is negative and significant as expected (except in the 1965-1970 model).

Several of the employment opportunity variables have a significant influence in the labor in-migration basic employment models. As expected, the employment opportunity variables for nonroutine manufacturing and producer services have a positive and significant association with basic employment growth (but the association is negative in the 1965-1970 model). The employment opportunity variable for routine manufacturing shows an insignificant association with growth in basic employment in the 1970-1975 model, and a negative and significant association with basic employment growth in the 1965-1970 labor in-migration model. What is unexpected is the significant and negative association between the variable for employment opportunities in routine 
manufacturing with growth in basic employment in the 1960-1965 model.

The traditional least cost variables have a significant influence on basic employment growth in the smaller metropolitan county models. The wage rate variable has a negative and significant association with basic employment growth in the labor in-migration models (except in the 1960-1965 model). The energy cost variable has an unexpected positive association with growth in basic employment.

Table XXV shows the results of the nonbasic employment model calibrations for the smaller metropolitan counties. The results are not always consistent with expectations. There is an unexpected similarity between the labor in-migration and out-migration models. Both the coefficients for labor in-migration and labor out-migration flows have a significant and positive association with the nonbasic employment variable.

The association between basic employment and nonbasic employment is as expected in the smaller metropolitan county models. In the 1960-1965 and 1970-1975 labor in-migration models, the association between basic employment growth and nonbasic employment growth is significant and positive. In the labor out-migration models, the association between basic employment and nonbasic employment is negative as expected, except in the 1960-1965 model. 
There are several unexpected associations between the employment opportunity variables and nonbasic employment growth. In the 1970-1975 labor in-migration model, the personal services and retail trade variable has a negative and significant association with nonbasic employment growth. The government services variable, on the other hand, has a significant and positive association with nonbasic employment growth in the 1970-1975 labor in-migration model. In the 1965-1970 labor in-migration model, there is no significant association between the employment opportunity variables and nonbasic employment growth. In the 1960-1.965 labor in-migration model, the personal services and retail trade variable, on the other hand, has a significant and positive association with nonbasic employment growth.

The coefficients for the employment opportunity variables are not always as originally expected in the labor out-migration model. In the labor out-migration model, the employment opportunity variable for personal services and retail trade have an insignificant association with nonbasic employment growth (except in the 1960-1965 model), whereas the government services variable has a significant and positive association with nonbasic employment growth.

The influence of the wage rate variable on nonbasic employment in the smaller metropolitan counties is spurious in the model results. The wage rate variable has a positive and significant association with nonbasic employment growth 
in the 1970-1975 labor in-migration model. Yet in the 1965-1970 labor in-migration model, the association is insignificant. In the 1960-1965 labor in-migration model, the association is significant and negative as expected. In the labor out-migration models, the wage rate variable has just a limited influence on nonbasic employment growth (refer to Table XXV).

The variable for population over 65 has only a minor influence on growth in nonbasic employment in the smaller metropolitan counties. The variable is insignificant (except in the 1970-1975 labor out-migration model).

\section{THE LARGER METROPOLITAN COUNTIES}

Tables XXVI-XXVII display the results for the large metropolitan county model calibrations. The following section analyzes the empirical results of the equations for the larger metropolitan county models. The calibrations for the larger metropolitan models explain a small to medium proportion of the specified relationship; the $\mathrm{R}$ squares for the labor migration model range from 0.289 to 0.657 .

Table XXVI displays the results of the model

calibrations for the labor migration flows to the large metropolitan counties. 
TABLE XXVI

METRO $>500,000$ COUNTIES LABOR MIGRATION MODEL

\begin{tabular}{|c|c|c|c|c|c|c|c|c|c|c|c|c|}
\hline & \multicolumn{5}{|c|}{ OUT-MIGRATIOH FLOW MOOEL } & \multicolumn{7}{|c|}{ IH-MIGRATION FLOW MOOEL } \\
\hline & \multicolumn{2}{|c|}{$1960-1965$} & \multicolumn{2}{|c|}{$1965-1970$} & \multicolumn{2}{|c|}{$1970-1975$} & \multicolumn{2}{|c|}{$1960-1965$} & \multicolumn{2}{|c|}{$1965-1970$} & $1970-1975$ & $\frac{1975}{T \text { for } \mathrm{HO}}$ \\
\hline CONSTANT & -33.015 & -4.423 & -20.187 & -1.867 & -4.731 & -0.341 & 0.045 & 0.007 & 1.984 & 0.346 & 1.466 & 0.671 \\
\hline $\begin{array}{l}\text { EMPLOYMEKT ACTIVITY VARIABLES } \\
\text { BASIC EMPLOYMENT } \\
\text { NOHBASIC EMPLOYMENT }\end{array}$ & $\begin{array}{l}-0.046 \\
-0.014\end{array}$ & $\begin{array}{l}-1.100 \\
-0.341\end{array}$ & $\begin{array}{l}-0.118 \\
-0.034\end{array}$ & $\begin{array}{l}-0.728 \\
-1.050\end{array}$ & $\begin{array}{l}-0.478 \\
-0.056\end{array}$ & $\begin{array}{l}-3.061 \\
-1.459\end{array}$ & $\begin{array}{l}0.090 \\
0.171\end{array}$ & $\begin{array}{l}0.956 \\
0.618\end{array}$ & $\begin{array}{r}-0.295 \\
0.138\end{array}$ & $\begin{array}{r}-2.499 \\
1.446\end{array}$ & $\begin{array}{r}-0.218 \\
0.149\end{array}$ & $\begin{array}{r}-3.702 \\
2.854\end{array}$ \\
\hline $\begin{array}{l}\text { ENVIRONKENTAL AMENITIES } \\
\text { COLLEGE } \\
\text { EXPENDITURES } \\
\text { RECREATIOH } \\
\text { INCOME }\end{array}$ & $\begin{array}{r}-0.026 \\
0.025 \\
0.130 \\
-4.779\end{array}$ & $\begin{array}{r}-2.020 \\
0.964 \\
2.855 \\
-4.688\end{array}$ & $\begin{array}{r}-0.022 \\
-0.050 \\
0.185 \\
-2.695\end{array}$ & $\begin{array}{r}-1.852 \\
-1.859 \\
3.958 \\
-1.998\end{array}$ & $\begin{array}{r}-0.016 \\
-0.059 \\
0.190 \\
-0.883\end{array}$ & $\begin{array}{r}-0.926 \\
-1.775 \\
3.356 \\
-0.474\end{array}$ & $\begin{array}{l}0.019 \\
0.019 \\
0.033 \\
0.271\end{array}$ & $\begin{array}{l}1.254 \\
0.541 \\
0.761 \\
0.309\end{array}$ & $\begin{array}{r}0.001 \\
0.105 \\
-0.099 \\
0.315\end{array}$ & $\begin{array}{r}0.066 \\
1.650 \\
-1.323 \\
0.428\end{array}$ & $\begin{array}{r}0.013 \\
0.052 \\
-0.042 \\
0.062\end{array}$ & $\begin{array}{r}0.958 \\
1.578 \\
-1.079 \\
0.359\end{array}$ \\
\hline $\begin{array}{l}\text { ENVIRONMENTAL DISAMENITIES } \\
\text { AGE DEPENDENCY } \\
\text { UNEMPLOYMENT } \\
\text { NONHHITE } \\
\text { CRIME } \\
\text { CLIMATE } \\
\text { HOUSING }\end{array}$ & $\begin{array}{r}-1.180 \\
-0.008 \\
0.119 \\
0.015 \\
-0.172 \\
-0.341\end{array}$ & $\begin{array}{r}-4.318 \\
-1.509 \\
2.732 \\
0.375 \\
-1.472 \\
-1.748\end{array}$ & $\begin{array}{r}-0.840 \\
-0.005 \\
0.053 \\
0.004 \\
0.026 \\
-0.074\end{array}$ & $\begin{array}{r}-1.769 \\
-0.815 \\
0.917 \\
0.120 \\
0.195 \\
-0.382\end{array}$ & $\begin{array}{r}0.191 \\
0.006 \\
-0.006 \\
-0.089 \\
-0.030 \\
0.058\end{array}$ & $\begin{array}{r}0.504 \\
0.904 \\
-0.129 \\
-2.317 \\
-0.193 \\
0.259\end{array}$ & $\begin{array}{r}-0.387 \\
-0.005 \\
0.010 \\
0.091 \\
0.236 \\
-0.346\end{array}$ & $\begin{array}{r}-0.943 \\
-0.365 \\
0.304 \\
1.265 \\
1.059 \\
-1.249\end{array}$ & $\begin{array}{r}-1.965 \\
-0.029 \\
-0.068 \\
0.236 \\
-0.125 \\
-0.711\end{array}$ & $\begin{array}{r}-3.015 \\
-1.653 \\
-0.731 \\
2.794 \\
-0.446 \\
-1.452\end{array}$ & $\begin{array}{r}-1.640 \\
-0.027 \\
-0.039 \\
0.189 \\
-0.232 \\
-0.823\end{array}$ & $\begin{array}{r}-4.763 \\
-3.136 \\
-0.796 \\
4.525 \\
-1.643 \\
-3.246\end{array}$ \\
\hline $\begin{array}{l}\text { ACCESSIBILITY } \\
\text { GRAVITY } \\
\text { CONTIGUOUS } \\
\text { POPULATION }\end{array}$ & $\begin{array}{r}0.252 \\
1.908 \\
-0.902\end{array}$ & $\begin{array}{r}6.690 \\
0.913 \\
-17.893\end{array}$ & $\begin{array}{r}0.276 \\
4.742 \\
-1.033\end{array}$ & $\begin{array}{r}2.625 \\
2.176 \\
-3.085\end{array}$ & $\begin{array}{r}0.563 \\
3.478 \\
-1.800\end{array}$ & $\begin{array}{r}4.669 \\
1.301 \\
-5.654\end{array}$ & $\begin{array}{r}0.119 \\
12.106 \\
-0.890\end{array}$ & $\begin{array}{r}1.916 \\
4.056 \\
-6.224\end{array}$ & $\begin{array}{r}0.141 \\
10.019 \\
-0.812\end{array}$ & $\begin{array}{r}1.716 \\
2.246 \\
-7.444\end{array}$ & $\begin{array}{r}0.268 \\
3.851 \\
-1.040\end{array}$ & $\begin{array}{r}5.075 \\
1.375 \\
-15.302\end{array}$ \\
\hline $\begin{array}{l}\text { F-VALUE } \\
\text { PROB } ; \\
R \text { SQUARE } \\
\text { ADJUSTED R } \\
\text { EXPLAINED SUM SOUARES } \\
\text { ERROR SUA SOUARES }\end{array}$ & $\begin{array}{r}316.210 \\
-0.000 \\
0.659 \\
0.657 \\
2117 \\
1097\end{array}$ & & $\begin{array}{r}196.831 \\
0.000 \\
0.546 \\
0.543 \\
2380 \\
1983\end{array}$ & & $\begin{array}{r}128.458 \\
0.000 \\
0.439 \\
0.436 \\
2130 \\
2719\end{array}$ & & $\begin{array}{l}68.085 \\
0.000 \\
0.293 \\
0.289 \\
3431 \\
826 i\end{array}$ & & $\begin{array}{l}62.630 \\
0.000 \\
0.276 \\
0.272 \\
2308 \\
6046\end{array}$ & & $\begin{array}{r}262.299 \\
0.000 \\
0.615 \\
0.613 \\
2552 \\
1596\end{array}$ & \\
\hline
\end{tabular}

Motes: 1) Both dependent and independent variables have been transformed into natural logarithm values.

2) numer of cases is 2470 yith 2474 dingraes of freedom $(h=15)$

3) Level of statistical significance is $95 \%$ or $|t| \geq 1.96$. 
TABLE XXVII

METRO > 500,000 COUNTIES BASIC EMPLOYMENT MODEL

\begin{tabular}{|c|c|c|c|c|c|c|c|c|c|c|c|c|}
\hline & \multicolumn{6}{|c|}{ OUT-MIGRATION FLOW MOOEL } & \multicolumn{6}{|c|}{ IN-MIGRATION FLOH MODEL } \\
\hline & \multicolumn{2}{|c|}{$1960-1965$} & \multicolumn{2}{|c|}{$1965 \cdot 1970$} & \multicolumn{2}{|c|}{$1970-1975$} & \multicolumn{2}{|c|}{$1960-1965$} & \multicolumn{2}{|c|}{$1965-1970$} & \multicolumn{2}{|c|}{$1970-1975$} \\
\hline CONSTAKT & 5.960 & 24.402 & 5.996 & 4.263 & 9.113 & 6.640 & 2.484 & 12.987 & 3.404 & 22.200 & 3.703 & 24.873 \\
\hline \multicolumn{13}{|l|}{ EXOCELOUS VARIABLES } \\
\hline LABOR MIGRATIOH FLOUS & 0.356 & 12.967 & 0.917 & 5.334 & 1.084 & 5.973 & -0.079 & -2.894 & 0.300 & 16.548 & 0.314 & 17.731 \\
\hline HOHBASIC EMPLOYMENT & 0.312 & 13.525 & -0.209 & -3.645 & -0.211 & -3.652 & 0.491 & 4.630 & 0.305 & 18.021 & 0.289 & 16.731 \\
\hline \multicolumn{13}{|l|}{ IADEPEKDENT VARIABLES } \\
\hline AGRICULTURAL SERVICES & 0.285 & 6.488 & 0.281 & 2.327 & 0.226 & 2.035 & -0.056 & -1.428 & 0.160 & 5.130 & 0.104 & 3.210 \\
\hline ROUTINE MANUFACTURING & -0.477 & -7.147 & 0.249 & 1.556 & 0.228 & 1.586 & -0.462 & -8.874 & 0.029 & 0.548 & -0.126 & -2.340 \\
\hline MOHROUTIKE MANUFACTURIHG & 0.369 & 21.127 & 0.001 & 0.016 & 0.025 & 0.638 & -0.046 & -0.340 & 0.255 & 19.294 & 0.320 & 21.828 \\
\hline PROOULER & 1.423 & 24.266 & 0.052 & 0.357 & 0.132 & 1.027 & 0.148 & 1.224 & 1.024 & 21.311 & 1.229 & 24.097 \\
\hline ENERGY & 0.571 & 9.928 & 0.110 & 0.779 & 0.179 & 1.374 & 0.172 & 2.616 & 0.245 & 5.413 & 0.305 & 6.631 \\
\hline WAGES & -2.021 & -19.185 & -0.763 & -3.002 & -0.901 & -3.952 & 0.768 & 4.692 & -1.878 & -21.929 & -2.055 & -23.253 \\
\hline FREEWAY & -0.043 & -1.157 & -0.202 & -1.867 & -0.134 & -1.319 & -0.167 & -2.768 & 0.105 & 3.953 & 0.087 & 3.154 \\
\hline F VALUE & 272.923 & & 160.776 & & 222.981 & & 41.543 & & 255.683 & & 280.287 & \\
\hline PROB > & 0.000 & & 0.000 & & 0.000 & & 0.000 & & 0.000 & & 0.000 & \\
\hline$R$ SQUARE & 0.499 & & 0.370 & & 0.449 & & 0.132 & & 0.483 & & 0.506 & \\
\hline ADJUSTED $R$ & 0.497 & & 0.368 & & 0.447 & & 0.129 & & 0.481 & & 0.504 & \\
\hline EXPLAINED SUM SOUARES & 1589 & & 526 & & 6001 & & 489 & & 53 & & 1009 & \\
\hline ERROR SUM SOUAKES & 1594 & & 1888 & & 7371 & & 3223 & & 1491 & & 987 & \\
\hline
\end{tabular}

Hotes: 1) Both dependent and independent variables have been transformed into natural logarithm values.

2) Number of spatiol interactions is 2479 with 2470 degrees of freedom (N-9).

3) Level of statistical significance is $95 \%$ or $|t| \geq 1.96$. 


\section{TABLE XXVIII}

METRO > 500,000 NONBASIC EMPLOYMENT MODEL

\begin{tabular}{|c|c|c|c|c|c|c|c|c|c|c|c|c|}
\hline & \multicolumn{6}{|c|}{ OUT-MIGRATION FLOW MOOEL } & \multicolumn{6}{|c|}{ IN-MIGRATION FLOW MODEL } \\
\hline & \multicolumn{2}{|c|}{$1960-1965$} & \multicolumn{2}{|c|}{$1965-1970$} & \multicolumn{2}{|c|}{$1970-1975$} & \multicolumn{2}{|c|}{$1960-1965$} & \multicolumn{2}{|c|}{$1965-1970$} & \multicolumn{2}{|c|}{$1970-1975$} \\
\hline & BETA & T for HO: & BETA & T for Ho: & BETA & T for Ho: & BETA & T for Ho: & BETA & T for HO: & BETA & T for Ho: \\
\hline CONSTANT & -4.590 & -16.632 & -11.574 & -11.572 & -10.131 & -10.157 & -0.517 & -2.833 & -2.318 & -8.721 & -1.653 & -6.259 \\
\hline \multicolumn{13}{|l|}{ ENDOGENOUS VARIABLES } \\
\hline LABOR MIGRATION FLOWS & -0.332 & -15.274 & -1.307 & -9.091 & -1.495 & -11.685 & 0.107 & 4.268 & -0.227 & -11.444 & -0.202 & -10.540 \\
\hline BASIC EMPLOYMEHT & 0.282 & 16.425 & -0.684 & -7.389 & -0.600 & -8.228 & 0.061 & 2.168 & 0.425 & 17.184 & 0.413 & 17.615 \\
\hline \multicolumn{13}{|l|}{ INDEPENDENT YARIABLES } \\
\hline$\overline{\text { PERSONAL SERVICES/RETAIL }}$ & 1.586 & 7.998 & 4.506 & 10.214 & 4.273 & 10.651 & -0.411 & -2.093 & 0.906 & 4.498 & 0.953 & 4.705 \\
\hline GOVERNMENT & -1.097 & -11.484 & -1.413 & -6.753 & -1.491 & -7.797 & -0.129 & -2.443 & -0.714 & -7.252 & -0.770 & -7.882 \\
\hline RETIREMENT & 0.128 & 1.330 & 0.302 & 1.361 & 0.295 & 1.470 & 0.036 & 0.742 & 0.087 & 0.913 & 0.056 & 0.591 \\
\hline WAGES & -1.120 & -5.915 & -3.511 & -8.159 & -3.235 & -8.293 & 0.237 & 1.381 & -0.538 & -2.798 & -0.586 & -3.024 \\
\hline F VALUE & 114.711 & & 501.189 & & 629.685 & & 14.537 & 1 & 110.442 & & 108.170 & \\
\hline $\mathrm{PROB}>\mathrm{F}$ & 0.000 & & 0.000 & & 0.000 & & 0.000 & & 0.000 & & 0.000 & \\
\hline$R$ SQUARE & 0.218 & & 0.549 & & 0.605 & & 0.034 & & 0.212 & & 0.208 & \\
\hline ADJUSTED R & 0.216 & & 0.548 & & 0.604 & & 0.032 & & 0.210 & & 0.206 & \\
\hline EXPLAIHED SUM SOUARES & 526 & & 11014 & & 11507 & & 53 & & 494 & & 484 & \\
\hline ERROR SUM SQUARES & 1888 & & 9040 & & 7517 & & 1491 & & 1841 & & 1842 & \\
\hline
\end{tabular}

Hotes: 1) Both dependent and independent variables have been trarisformed into natural logarithm values.

2) Number of spatial interactions is 2479 with 2473 degrees of freedom $(N-6)$.

3) Level of statistical significance is $95 \%$ or $|t|>1.96$. 
The influence of the environmental amenity variables on labor migration flows to larger metropolitan counties is minimal. None of environmental amenity variables has a significant association with labor in-migration. In the labor out-migration models, the environmental amenity variables have a limited influence on labor out-migration flows as well. The recreational opportunities variable has a significant, but unexpected association with labor out-migration flows. In the 1960-1965 model, just the income differentials variable has the expected negative and significant association with labor out-migration flows.

Several of the environmental disamenity variables have a significant influence on labor in-migration flows to large metropolitan areas. In the 1970-1975 model, the age dependency, unemployment, and housing price variables have a negative and significant association with labor in-migration flows. In the 1965-1970 model, the age dependency variable has the expected negative and significant influence on labor in-migration, whereas the crime rate has the unexpected significant and positive influence on labor in-migration flows. In the 1960-1965 model, the age dependency variable has the significant and negative influence on labor in-migration flows.

Environmental disamenities have a limited influence on labor out-migration flows to the larger metropolitan areas. Just two of the environmental disamenity variables have a 
significant association with labor out-migration flows. In the 1960-1965 model, the age dependency variable has an unexpected significant and negative influence on labor out-migration flows, whereas percentage nonwhite has the expected significant and positive influence on labor out-migration flows.

Accessibility has a significant influence on labor migration flows to the larger metropolitan areas. In most of the model results, the labor potential index has a positive and significant association with labor migration flows. Moves from contiguous counties have a positive influence on labor migration flows to the large metropolitan areas (except in the 1965-1970 labor out-migration model). Population size has a negative influence on labor migration flows to the large metropolitan areas (see Table XXVI). Basic employment growth has a negative association with labor in-migration flows in the large metropolitan model results, except in the 1960-1965 model. Conversely, basic employment growth has a negative and significant association with labor out-migration flows in the 1970-1975 model results.

Nonbasic employment growth has a limited influence on labor migration flows to the large metropolitan areas. In most of the models, nonbasic employment growth has an insignificant influence on labor migration flows. 
Table XXVII shows that in most of the large metropolitan models, the influence of labor migration flows on growth in basic employment is significant and positive. What is not expected is the positive and significant association between labor out-migration and growth in basic employment.

The effect of the shift of economic activities in the large metropolitan areas from routine manufacturing to other industrial sectors is seen in Table XXVII. The variable for routine manufacturing shows a negative and significant association with growth in basic employment in the labor in-migration models (except for the 1965-1970 model), whereas the variable for nonroutine manufacturing has a significant and positive influence on basic employment growth in the labor in-migration models. In the labor out-migration models, the association between the nonroutine manufacturing variable and basic employment growth is insignificant (except in the 1960-1965 model).

The hypothesis that producer services have a significant influence on growth in basic employment in the large metropolitan areas is supported by the model calibrations. The variable for producer services has a significant and positive association with growth in basic employment in the labor in-migration models (except in the 1960-1965 model). 
A surprising result of the large metropolitan model calibrations is the significant association between the employment opportunity variable for agricultural services and growth in basic employment. The employment opportunity variable for agricultural services has a positive and significant association with growth in basic employment.

The empirical results for the large metropolitan counties are more consistent with the classical location theory than the results found in the nonmetropolitan models. The variable for wage rates has a significant and negative association with growth in basic employment in most of the labor in-migration models as expected. However, the variable for energy rates has a positive and significant association with growth in basic employment.

Access is a major influence on growth of basic employment in the large metropolitan areas. The freeway variable has a significant and positive association with basic employment, except in the 1960-1965 labor in-migration model.

Table XXVIII displays the results of the calibration on the nonbasic employment models for the large metropolitan areas.

The association between labor migration flows and growth in nonbasic employment is not as expected. The labor in-migration flow variable has an unexpected negative and significant association with growth in nonbasic employment 
(except in the 1960-1965 model). In the labor out-migration nodels, the labor migration flow variable has the expected significant and negative association with employment.

The growth in basic employment has the expected significant and positive influence on growth in nonbasic employment in the labor in-migration models. In the labor out-migration models, growth in basic employment has a significant and negative association with growth in nonbasic employment.

The employment opportunity variables have a significant influence on growth in nonbasic employment, but not always as expected. The employment opportunity variable for personal services and retail trade has a significant and positive influence on growth in nonbasic employment in the labor in-migration models. Whereas, the government service variable has a significant and negative association with growth in nonbasic employment.

The association between growth in nonbasic employment and the wage rate variable is significant and negative as expected (except for the 1960-1965). What is not expected is the lack of symmetry between the labor in-migration and out-migration model results.

The influence of retirement is not significant in the large metropolitan area models (see Table XXVII). 
TESTING THE PUSH AND PULL MODELS

FOR SPATIAL DIFFERENCES

The factors behind the nonmetropolitan turnaround and economic deconcentration vary spatially according to population size and proximity to metropolitan regions. The F tests used to compare whether the beta coefficients are equal for the adjacent and nonadjacent models show that one cannot assume the beta coefficients are equal for the nonmetropolitan models. Nor can one assume the beta coefficients are equal for the large and small metropolitan models (refer to the Appendix C).

\section{A COMPARISON OF SPATIAL MODEL RESULTS}

The following section summarizes the similarities and differences found in the nonmetropolitan and metropolitan county model results for the turnaround period (the 1970-1975 model results). The results of the $F$ tests used to test whether the coefficients of the nonmetropolitan and metropolitan models are equal show that the nonadjacent and adjacent nonmetropolitan models are significantly different and the small and large metropolitan models are significantly different as well. Several of the estimated parameters have opposite signs in the metropolitan and nonmetropolitan model calibrations. However, the differences found between the two nonmetropolitan county model results are much greater than the differences found 
for the two metropolitan county model results (see Tables $\mathrm{XXIX}-\mathrm{XXX})$.

Tables XXIX and XXX compare the 1970-1975 labor migration flow model results for different county types studied. Table XXIX shows the results for the two nonmetropolitan county types studied (the nonadjacent and nonadjacent county models). Table XXX shows the results for the two metropolitan county types studies (the smaller metropolitan county with populations less than 500,000 and the large metropolitan areas with populations greater than $500,000)$

The influence of environmental amenities and disamenities is limited, if not spurious in most of the model calibrations. The environmental amenity variables are more important in the nonadjacent nonmetropolitan model results. In particular, college enrollment has a significant and positive influence on labor in-migration to the nonadjacent counties.

The environmental disamenity variables, on the other hand, have a greater influence on labor migration to the larger metropolitan counties than they do on labor migration to the nonadjacent, adjacent and smaller metropolitan counties. Most of the environmental disamenity variables have a negative association with labor in-migration (with the exception of the crime index variable in the larger metropolitan county models). The crime rate variable has 
TABLE XXIX

NONMETROPOLITAN COUNTIES LABOR MIGRATION MODEL, 1970-1975

\begin{tabular}{|c|c|c|c|c|c|c|c|c|c|c|}
\hline & \multicolumn{3}{|c|}{ OUT-MIGRATION FLOW MOOELS } & \multicolumn{7}{|c|}{ IN-MIGRATIOH FLOW MODELS } \\
\hline & \multicolumn{4}{|c|}{ NONADJACENT COUNTIES ADJACENT COUNTIES } & \multicolumn{6}{|c|}{ NONADJACENT COUNTIES ADJACEHT COUNTIES } \\
\hline & BETA & T for Ho: & BETA & T for Ho: & EXPECTED & BETA & $T$ for Ho: & BETA & $T$ for Ho: & EXPECTED \\
\hline CONSTANT & 3.935 & 3.492 & 0.830 & 1.709 & & 4.571 & 4.427 & 2.276 & 3.076 & \\
\hline $\begin{array}{l}\text { EMPLOYMEHT VARIABLES } \\
\text { BASIC } \\
\text { NONBASIC }\end{array}$ & $\begin{array}{r}-0.047 \\
0.001\end{array}$ & $\begin{array}{r}-4.409 \\
0.170\end{array}$ & $\begin{array}{l}-1.583 \\
-2.010\end{array}$ & $\begin{array}{l}-1.713 \\
-1.458\end{array}$ & : & $\begin{array}{r}-0.002 \\
0.004\end{array}$ & $\begin{array}{r}-0.147 \\
0.189\end{array}$ & $\begin{array}{l}0.010 \\
0.026\end{array}$ & $\begin{array}{l}0.837 \\
0.575\end{array}$ & + \\
\hline $\begin{array}{l}\text { ENVIRONMENTAL AKENITIES } \\
\text { COLLEGE } \\
\text { EXPENDITURES } \\
\text { RECREATION } \\
\text { INCOME }\end{array}$ & $\begin{array}{r}-0.005 \\
-0.001 \\
0.002 \\
0.093\end{array}$ & $\begin{array}{r}-0.791 \\
-0.385 \\
0.493 \\
0.568\end{array}$ & $\begin{array}{r}0.564 \\
-1.115 \\
0.416 \\
-0.580\end{array}$ & $\begin{array}{r}0.883 \\
-1.203 \\
-0.978 \\
0.359\end{array}$ & $\dot{-}$ & $\begin{array}{r}0.006 \\
-0.002 \\
0.012 \\
0.195\end{array}$ & $\begin{array}{r}1.960 \\
-0.425 \\
1.712 \\
1.464\end{array}$ & $\begin{array}{l}0.003 \\
0.005 \\
0.012 \\
0.085\end{array}$ & $\begin{array}{l}0.443 \\
0.524 \\
1.794 \\
1.156\end{array}$ & $\begin{array}{l}+ \\
+ \\
+\end{array}$ \\
\hline $\begin{array}{l}\text { ENVIRONMENTAL DISAMENITY } \\
\text { AGE DEPENDENCY } \\
\text { UNEMPLOYMENT } \\
\text { NOHWHITE } \\
\text { CRIME } \\
\text { CLIMATE } \\
\text { HOUSIHG }\end{array}$ & $\begin{array}{r}-0.033 \\
-0.000 \\
-0.001 \\
0.040 \\
-0.043 \\
-0.021\end{array}$ & $\begin{array}{r}-0.816 \\
-0.067 \\
-0.100 \\
9.417 \\
-2.140 \\
-1.122\end{array}$ & $\begin{array}{r}-3.427 \\
-0.846 \\
0.870 \\
3.059 \\
-0.576 \\
-2.176\end{array}$ & $\begin{array}{r}-3.077 \\
-1.150 \\
1.066 \\
6.436 \\
-0.723 \\
-3.343\end{array}$ & $\begin{array}{l}+ \\
+ \\
+ \\
+ \\
+\end{array}$ & $\begin{array}{r}0.065 \\
-0.002 \\
-0.001 \\
0.026 \\
-0.025 \\
0.021\end{array}$ & $\begin{array}{r}0.662 \\
-0.835 \\
-0.097 \\
1.354 \\
-0.592 \\
0.511\end{array}$ & $\begin{array}{r}-0.073 \\
-0.004 \\
0.025 \\
0.013 \\
0.073 \\
-0.055\end{array}$ & $\begin{array}{r}-0.541 \\
-1.137 \\
1.367 \\
0.956 \\
1.697 \\
-1.069\end{array}$ & $\begin{array}{l}- \\
\dot{-} \\
\dot{-} \\
-\end{array}$ \\
\hline $\begin{array}{l}\text { ACCESSIBILITY } \\
\text { GRAVITY } \\
\text { CONTIGUOUS } \\
\text { POPULATIOH }\end{array}$ & $\begin{array}{r}0.073 \\
0.200 \\
-1.044\end{array}$ & $\begin{array}{r}7.169 \\
0.359 \\
-55.470\end{array}$ & $\begin{array}{r}1.707 \\
-1.096 \\
-13.666\end{array}$ & $\begin{array}{r}2.716 \\
0.063 \\
-21.840\end{array}$ & + & $\begin{array}{r}0.040 \\
2.592 \\
-0.991\end{array}$ & $\begin{array}{r}11.588 \\
1.442 \\
-43.174\end{array}$ & $\begin{array}{r}0.077 \\
-1.639 \\
-0.976\end{array}$ & $\begin{array}{r}6.863 \\
-1.482 \\
-36.347\end{array}$ & + \\
\hline $\begin{array}{l}\text { F-VALUE } \\
\text { PROB > } \\
\text { R SQUARE } \\
\text { AD JUSTED R }\end{array}$ & $\begin{array}{r}11764.322 \\
0.000 \\
0.960 \\
0.960\end{array}$ & & $\begin{array}{r}3713.749 \\
0.000 \\
0.912 \\
0.912\end{array}$ & & & $\begin{array}{r}3083.090 \\
0.000 \\
0.863 \\
0.862\end{array}$ & & $\begin{array}{r}1293.007 \\
0.000 \\
0.782 \\
0.782\end{array}$ & & \\
\hline
\end{tabular}

Hotes: 1) Both dependent and imependent variables have been transformed into natural logarithm values.

2) Number of nonadjacent interactions is 7389 and adjacent interactions is 5407 with $\mathrm{N}-15$ degrees of freedom. 
TABLE XXX

METROPOLITAN COUNTIES LABOR MIGRATION MODEL, 1970-1975

\begin{tabular}{|c|c|c|c|c|c|c|c|c|c|c|}
\hline & \multicolumn{5}{|c|}{ OUT-MIGRATION FLOW MOOELS } & \multicolumn{4}{|c|}{ IH-AIGRATION FLOW MODELS } & \\
\hline & \multicolumn{2}{|c|}{ METRO $<500,000$} & \multicolumn{2}{|c|}{ METRO > 500,000 } & \multirow[b]{2}{*}{ EXPECTED } & \multicolumn{2}{|c|}{ METRO $<500,000$} & \multicolumn{2}{|c|}{ METRO > 500,000 } & \\
\hline & BETA & $T$ for Ho: & BETA & T for Ho: & & BETA & $T$ for Ho: & BETA & $T$ for Ho: & EXPECTED \\
\hline CONSTAHT & 7.986 & $0.667=$ & -13.545 & -1.142 & & -2.859 & -0.820 & 1.466 & 0.671 & \\
\hline $\begin{array}{l}\text { EMPLCYMENT ACTIVITY VARIABLES } \\
\text { BASIC EMPLOYMENT } \\
\text { NONBASIC EMPLOYMENT }\end{array}$ & $\begin{array}{r}-0.102 \\
0.005\end{array}$ & $\begin{array}{r}-0.943 \\
0.109\end{array}$ & $\begin{array}{l}-0.342 \\
-0.060\end{array}$ & $\begin{array}{l}-2.513 \\
-1.841\end{array}$ & : & $\begin{array}{l}0.002 \\
0.007\end{array}$ & $\begin{array}{l}0.004 \\
0.056\end{array}$ & $\begin{array}{r}-0.218 \\
0.149\end{array}$ & $\begin{array}{r}-3.702 \\
2.854\end{array}$ & + \\
\hline $\begin{array}{l}\text { ENVIRONMENTAL AMENITIES } \\
\text { COLLEGE } \\
\text { EXPENDITURES } \\
\text { RECREATIOK } \\
\text { IHCOME }\end{array}$ & $\begin{array}{r}0.002 \\
-0.027 \\
-0.014 \\
1.223\end{array}$ & $\begin{array}{r}0.127 \\
-0.731 \\
-0.541 \\
0.695\end{array}$ & $\begin{array}{r}0.011 \\
-0.046 \\
0.158 \\
-1.804\end{array}$ & $\begin{array}{r}0.648 \\
-1.638 \\
3.261 \\
-1.129\end{array}$ & $\begin{array}{l}- \\
- \\
-\end{array}$ & $\begin{array}{r}0.013 \\
-0.014 \\
0.035 \\
0.186\end{array}$ & $\begin{array}{r}0.541 \\
-0.687 \\
1.545 \\
0.670\end{array}$ & $\begin{array}{r}0.013 \\
0.052 \\
-0.042 \\
0.062\end{array}$ & $\begin{array}{r}0.958 \\
1.578 \\
-1.079 \\
0.359\end{array}$ & $\begin{array}{l}+ \\
+ \\
+ \\
+\end{array}$ \\
\hline $\begin{array}{l}\text { ENVIRONMENTAL DISAMENITIES } \\
\text { AGE DEPENDENCY } \\
\text { UNEMPLOYMENT } \\
\text { HONWHITE } \\
\text { CRIME } \\
\text { CLIMATE } \\
\text { HOUSING }\end{array}$ & $\begin{array}{r}0.265 \\
-0.002 \\
0.122 \\
-0.065 \\
0.230 \\
0.055\end{array}$ & $\begin{array}{r}0.610 \\
-0.229 \\
1.454 \\
-0.978 \\
1.220 \\
0.377\end{array}$ & $\begin{array}{r}0.001 \\
0.004 \\
-0.008 \\
-0.018 \\
0.028 \\
0.107\end{array}$ & $\begin{array}{r}0.004 \\
0.699 \\
-0.208 \\
-0.530 \\
0.211 \\
0.565\end{array}$ & $\begin{array}{l}+ \\
+ \\
+ \\
+ \\
+ \\
+\end{array}$ & $\begin{array}{r}0.771 \\
0.011 \\
0.124 \\
-0.027 \\
0.525 \\
0.390\end{array}$ & $\begin{array}{r}1.303 \\
0.425 \\
1.121 \\
-0.591 \\
1.561 \\
1.133\end{array}$ & $\begin{array}{r}-1.640 \\
-0.027 \\
-0.039 \\
0.189 \\
-0.232 \\
-0.823\end{array}$ & $\begin{array}{r}-4.763 \\
-3.136 \\
-0.796 \\
4.525 \\
-1.643 \\
-3.246\end{array}$ & $\begin{array}{l}- \\
- \\
- \\
-\end{array}$ \\
\hline $\begin{array}{l}\text { ACCESSIBILITY } \\
\text { GRAVITY } \\
\text { CONTIGUOUS } \\
\text { POPULATION }\end{array}$ & $\begin{array}{r}0.277 \\
-2.549 \\
-1.218\end{array}$ & $\begin{array}{r}3.318 \\
-0.744 \\
-6.592\end{array}$ & $\begin{array}{r}0.478 \\
2.488 \\
-1.480\end{array}$ & $\begin{array}{r}4.686 \\
1.222 \\
-5.631\end{array}$ & + & $\begin{array}{r}0.244 \\
-3.063 \\
-1.066\end{array}$ & $\begin{array}{r}2.863 \\
-0.606 \\
-17.386\end{array}$ & $\begin{array}{r}0.268 \\
3.851 \\
-9.040\end{array}$ & $\begin{array}{r}5.075 \\
1.375 \\
-15.302\end{array}$ & + \\
\hline $\begin{array}{l}\text { F-VALUE } \\
\text { PROB > } \\
\text { R SQUARE } \\
\text { AD JUSTED R }\end{array}$ & $\begin{array}{r}152.297 \\
0.000 \\
0.507 \\
0.503\end{array}$ & & $\begin{array}{r}177.679 \\
0.000 \\
0.520 \\
0.517\end{array}$ & & & $\begin{array}{r}151.291 \\
0.000 \\
0.505 \\
0.502\end{array}$ & & $\begin{array}{r}262.299 \\
0.000 \\
0.615 \\
0.613\end{array}$ & & \\
\hline
\end{tabular}

Wotes: 1 ) Both dependent and independent variables hove been transformed into natural logari thm values.

2) Number of small metropolitan cases is 2479 and 2239 with 15 degrees of freedom. 
the expected negative and significant association in the smaller metropolitan labor in-migration model.

Accessibility has a significant influence on labor migration flows. The labor potential index has a positive and significant association with labor migration in all the model results. The effect of movement between contiguous counties has a significant and positive influence on labor in-migration to the large metropolitan counties, but an insignificant influence in the other spatial model results. This may be a result of commuting from the exurban fringe to the larger metropolitan counties. Population size is inversely related to labor in-migration in all the spatial models tested.

Tables XXXI and XXXII display the differences found in the nonmetropolitan and metropolitan basic employment models. The basic employment model results are not consistent with some of the scholarly work on industrialization in the United States, which postulates that the turnaround is a result of the spatial division of labor (Bluestone \& Harrison, 1982; Clark, 1981; Cohen \& Zysman, 1987). The spatial division of labor hypothesis postulates that nonmetropolitan growth is the consequence of a spatial filtering of routine manufacturing employment from metropolitan counties to the peripheral nonmetropolitan counties in the 1970s. According to the spatial division of labor hypothesis, employment growth in nonmetropolitan 
TABLE XXXI

NONMETROPOLITAN BASIC EMPLOYMENT MODEL, 1970-1975

\begin{tabular}{|c|c|c|c|c|c|c|c|c|c|c|}
\hline & \multicolumn{3}{|c|}{ OUT-HIGRATION FLON MOOELS } & \multicolumn{7}{|c|}{ IN-MIGRATIOH FLON HOOELS } \\
\hline & \multicolumn{4}{|c|}{ HOWADJACENT COUHTIES ADJACENT COUNTIES } & \multicolumn{6}{|c|}{ MOHADJACEHT COUHTIES ADJACENT COUHTIES } \\
\hline & BETA & T for Ho: & BETA & T for Ho: & EXPECTED & BETA & T for Ho: & BETA & T for Ho: & EXPECTED \\
\hline CONSTANT & 2.906 & 22.117 & 4.550 & 6.661 & & 2.532 & 40.908 & 1.789 & 6.290 & \\
\hline \multicolumn{11}{|l|}{ EMDOGENOUS VARIABLES } \\
\hline LABOR MIGRATIOH FLOWS & 0.237 & 11.837 & 0.026 & 1.600 & - & 0.187 & 19.979 & -0.168 & -5.498 & + \\
\hline HONBASIC EMPLOYMENT & -0.863 & -73.494 & -65.199 & -64.339 & - & 0.528 & 15.678 & -0.611 & -9.358 & + \\
\hline \multicolumn{11}{|l|}{ INDEPENDENT VARIABLES } \\
\hline AGRICULTURAL SERVICES & -0.136 & -5.156 & -4.294 & -4.508 & + & -0.055 & -3.879 & -0.583 & -16.661 & - \\
\hline ROUTIINE MANUFACTURIHG & -0.238 & -5.076 & -6.513 & -6.536 & - & -0.218 & -9.993 & -0.031 & -1.016 & + \\
\hline PROOUCER & 0.142 & 4.151 & -0.475 & -0.958 & - & 0.321 & 11.153 & 0.556 & 6.787 & + \\
\hline EMERGY & 0.005 & 0.113 & -0.288 & -0.449 & + & -0.238 & -10.207 & 1.030 & 16.753 & - \\
\hline MAGES & -0.126 & -1.397 & 1.053 & 1.565 & + & 0.557 & 10.626 & 0.458 & 6.215 & - \\
\hline FREEHAY & -0.917 & -6.491 & 2.352 & 3.605 & + & 1.281 & 16.670 & 0.474 & 6.447 & - \\
\hline F VALUE & 1071.005 & & 780.373 & & & 220.262 & & 147.887 & & \\
\hline PROB > & 0.000 & & 0.000 & & & 0.000 & & 0.000 & & \\
\hline R SQUARE & 0.537 & & 0.536 & & & 0.193 & & 0.180 & & \\
\hline ADJUSTED R & 0.537 & & 0.536 & & & 0.192 & & 0.179 & & \\
\hline
\end{tabular}

Motes: 1) Both dependent and independent variables have been transformed into natural logarithm values.

2) Humber of nonadjacent interactions is 7389 and adjacent interactions is 5407 with $\mathrm{H}-8$ degrees of freedom.

3) Level of statistical significance is $95 x$ or $|t| \geq 1.96$. 
TABLE XXXII

\section{METROPOLITAN BASIC EMPLOYMENT MODEL}

\begin{tabular}{|c|c|c|c|c|c|c|c|c|c|c|}
\hline & \multicolumn{5}{|c|}{ OUT-MIGRATION FLOW HOOEL } & \multicolumn{5}{|c|}{ IH-MIGRATIOH FLOW MODEL } \\
\hline & \multicolumn{2}{|c|}{ HETRO $<500,000$} & \multicolumn{2}{|c|}{ METRO > 500,000} & \multirow[b]{2}{*}{ EXPECTED } & \multicolumn{2}{|c|}{ METRO $<500,000$} & \multicolumn{2}{|c|}{ METRO > 500,000 } & \multirow[b]{2}{*}{ EXPECTED } \\
\hline & BETA & $T$ for Ho: & BETA & $T$ for Ho: & & BETA & $T$ for Ho: & BETA & I for Ho: & \\
\hline CONSTANT & 5.883 & 11.075 & 7.833 & 5.954 & & 2.182 & 20.304 & 3.703 & 24.873 & \\
\hline \multicolumn{11}{|l|}{ ENDOGENOUS VARIABLES } \\
\hline LABOR MIGRATIOH FLOWS & 0.557 & 7.052 & 0.917 & 5.257 & - & 0.082 & 1.138 & 0.314 & 17.731 & + \\
\hline NONBASIC EKPLOYMENT & -0.590 & -29.669 & -0.262 & -4.702 & - & -0.026 & 16.299 & 0.289 & 16.731 & + \\
\hline \multicolumn{11}{|l|}{ INDEPENDENT VARIABLES } \\
\hline AGRICULTURAL SERVICES & 0.220 & 3.501 & 0.322 & 2.966 & + & 0.311 & 5.928 & 0.104 & 3.210 & - \\
\hline ROUTINE MANUFACTURING & 1.510 & 10.490 & 0.329 & 2.409 & + & 0.997 & -0.814 & -0.126 & -2.340 & - \\
\hline MOHROUT INE MAKUFACTURIKG & -0.234 & -4.667 & -0.028 & -0.803 & - & -0.133 & 2.859 & 0.320 & 21.828 & + \\
\hline PRODUCER & 1.414 & 8.963 & 0.101 & 0.805 & - & 1.083 & 6.062 & 1.229 & 24.097 & + \\
\hline EKERGY & 0.928 & 7.213 & 0.133 & 1.058 & - & 0.550 & 5.241 & 0.305 & 6.631 & - \\
\hline WAGES & -3.724 & -11.356 & -0.878 & -3.954 & - & -2.525 & -4.232 & -2.055 & -23.253 & - \\
\hline FREEUAY & -0.140 & -2.184 & -0.199 & -2.011 & - & -0.308 & -18.055 & 0.087 & 3.154 & + \\
\hline F VALUE & 297.131 & & 237.786 & & & 741.782 & & 280.287 & & \\
\hline PROB > & 0.000 & & 0.000 & & & 0.000 & & 0.000 & & \\
\hline R SQUARE & 0.545 & & 0.465 & & & 0.749 & & 0.506 & & \\
\hline ADJUSTED R & 0.544 & & 0.463 & & & 0.748 & & 0.504 & & \\
\hline
\end{tabular}

Hotes: 1) Both dependent and independent variables have been transformed into natural logarithm values.

2) Number of small metropolitan interactions is 2239 and large metropolitan interactions is 2479 with $\mathrm{N}-8$ degrees of freedom.

3) Level of statistical significance is $95 \%$ or $|t| \geq 1.96$. 
counties should be negatively associated with wage rates. The model results for this study show this is not the case for the nonmetropolitan counties in the three Pacific states.

This study finds that nonmetropolitan counties also underwent a de-industrialization process. Consequently, the variable for employment opportunity in producer services has a significant and positive association with growth in basic employment. Moreover, the variable for routine manufacturing has a negative association with growth in basic employment in the nonmetropolitan county models. Basic employment growth in the metropolitan counties is no longer dependent on growth in routine manufacturing. The metropolitan counties in the Pacific states are experiencing a post-industrial restructuring to a high technology and service-oriented economy. Basic employment growth shows a significant association with the employment opportunity variables for nonroutine manufacturing and producer services.

The economic cost variables show different associations in the metropolitan and nonmetropolitan model results. The wage rate variables have a negative influence on basic employment growth in the metropolitan county models, while in the nonmetropolitan county model results they have a positive influence. Energy costs, however, show no significant association with growth in basic employment. 
Access as measured by the interstate freeway system remains a significant factor in growth of basic employment activities in both the nonmetropolitan and metropolitan counties.

The relatively low $R$ squares in both the nonmetropolitan and metropolitan basic employment growth models indicate that other factors mentioned in the turnaround literature but which are not addressed in this dissertation may play a greater role in stimulating growth in basic employment in nonmetropolitan counties, i.e., an nonlocal corporate decision makers, availability of a skilled labor pool, and cheap land (Kale \& Lonsdale, 1979). Tables XXXIII and XXXIV show the differences found between the nonmetropolitan and metropolitan nonbasic employment models. Growth in nonbasic employment in the larger metropolitan counties (but not the smaller metropolitan counties) is associated with central place activities (i.e., retail trade and personal services). What is unexpected is that the variable for employment opportunity in government services has a negative and significant association with growth in nonbasic employment. The retirement variable has no significant effect on growth in nonbasic employment in the metropolitan county models. 
TABLE XXXIII

NONMETROPOLITAN NONBASIC EMPLOYMENT MODEL

\begin{tabular}{|c|c|c|c|c|c|c|c|c|c|c|}
\hline & \multicolumn{5}{|c|}{ OUT-HIGRATION FLON HOOEL } & \multicolumn{4}{|c|}{ IN-MIGRATION FLOW MOOEL } & \\
\hline & \multicolumn{2}{|c|}{ HONADJACENT COUHTIES } & \multicolumn{3}{|c|}{ ADJACENT COUHTIES } & \multicolumn{2}{|c|}{ MONADJACENT COUNTIES } & \multicolumn{2}{|c|}{ ADJACENT COUHTIES } & \multirow[b]{2}{*}{ EXPECTED } \\
\hline & BETA & $T$ for Ho: & BETA & T for Ho: & EXPECTED & $T$ for Ho: & $T$ for Ho: & $T$ for Ho: & $T$ for Ho: & \\
\hline CONSTANT & 5.042 & 18.711 & 8.570 & 5.870 & & 1.200 & 9.026 & 0.339 & 3.072 & \\
\hline \multicolumn{11}{|l|}{ EHDOGENOUS VARIABLES } \\
\hline LABOR RIGRATION FLOWS & 0.335 & 9.803 & 1.480 & 2.490 & - & -0.001 & -0.624 & -0.006 & -0.466 & + \\
\hline BASIC EMPLOYMENT & -1.041 & -72.095 & -65.523 & $-65.4 \pi$ & - & -0.100 & -6.193 & 0.094 & 7.688 & + \\
\hline \multicolumn{11}{|l|}{ INDEPENDENT VARIABLES } \\
\hline$\overline{\text { PERSOWAL SERVICE/RETAIL }}$ & 0.010 & 0.058 & -0.044 & 0.525 & - & -1.270 & -10.028 & 0.227 & 2.714 & + \\
\hline GOVERHMENT & -0.344 & -5.081 & -1.596 & -2.553 & - & -0.380 & -13.084 & -0.331 & -10.146 & + \\
\hline RETIREMENT & 0.527 & 5.788 & 0.409 & -3.982 & - & -0.437 & 16.708 & -0.124 & -3.809 & + \\
\hline HAGES & 0.210 & 1.363 & 3.349 & 2.670 & + & 0.493 & 4.445 & 0.164 & 2.193 & - \\
\hline F VALUE & 1170.291 & & 1149.300 & & & 128.917 & & 148.330 & & \\
\hline PROB > F & 0.000 & & 0.000 & & & 0.000 & & 0.000 & & \\
\hline$R$ SQUUARE & 0.488 & & 0.561 & & & 0.095 & & 0.142 & & \\
\hline AD JUSTED R & 0.487 & & 0.560 & & & 0.094 & & 0.140 & & \\
\hline
\end{tabular}

Wotes: 1) Both dependent and independent variables have been transformed into natural logari thm values.

2) Number of monadjacent interactions is 7389 and adjacent interactions is 5407 with N-6 degrees of freedom.

3) Level of statistical significance is $95 \%$ or $|t| \geq 1.96$. 
TABLE XXXIV

METROPOLITAN NONBASIC EMPLOYMENT MODEL

\begin{tabular}{|c|c|c|c|c|c|c|c|c|c|c|}
\hline & \multicolumn{5}{|c|}{ OUT-MIGRATIOH FLOH MOOEL } & \multicolumn{4}{|c|}{ IH-HIGRATION FLOA MODEL } & \\
\hline & \multicolumn{2}{|c|}{ METRO COUHTIES $<500,000$} & \multicolumn{3}{|c|}{ METRO COUNTIES > 500,000 } & \multicolumn{2}{|c|}{ METRO $<500,000$} & \multicolumn{2}{|c|}{ HETRO > 500,000 } & \\
\hline & BETA & $T$ for Ho: & BETA & T for Ho: & EXPECTED & BETA & $T$ for Ho: & BETA & T for Ho: & EXPECTED \\
\hline CONSTAKT & 7.188 & 4.488 & -9.893 & -9.978 & & -0.176 & -1.090 & -1.653 & -6.259 & \\
\hline \multicolumn{11}{|l|}{ ENDOGENOUS VARIABLES } \\
\hline LABOR MIGRATIOH FLOWS & 1.007 & 3.298 & -1.460 & -11.499 & - & 0.062 & 2.325 & -0.202 & -10.540 & + \\
\hline BASIC EMPLOYMENT & -1.616 & -20.239 & -0.627 & -8.621 & - & 1.333 & 38.641 & 0.413 & 17.615 & + \\
\hline \multicolumn{11}{|l|}{ INDEPEHDEHT VARIABLES } \\
\hline$\overline{\text { PERSOHAL SERVICES/RETAIL }}$ & -0.315 & -0.182 & 4.314 & 10.739 & - & -1.578 & -4.461 & 0.953 & 4.705 & + \\
\hline GOVERHMENT & -0.061 & -0.299 & -1.485 & -7.767 & - & 0.118 & 2.836 & -0.770 & -7.882 & + \\
\hline REYIREMENT & -1.271 & -2.574 & 0.279 & 1.388 & - & 0.117 & 1.769 & 0.056 & 0.591 & + \\
\hline WAGES & 1.149 & 0.593 & -3.284 & -8.405 & - & 1.508 & 4.096 & -0.586 & -3.024 & - \\
\hline F VALUE & 296.248 & & 632.721 & & & 294.296 & & 108.170 & & \\
\hline PROB > F & 0.000 & & 0.000 & & & 0.000 & & 0.000 & & \\
\hline R SOUARE & 0.443 & & 0.606 & & & 0.441 & & 0.208 & & \\
\hline ADJUSTED $R$ & 0.442 & & 0.605 & & & 0.440 & & 0.206 & & \\
\hline
\end{tabular}

Notes: 1) Both dependent and independent variables have been transformed into natural logarichm values.

2) Humer of small metropolitan interactions is 2239 and large metropolitan interactions is 2479 with $\mathrm{H}-6$ degrees of freedom.

3) Level of statistical significance is $95 \%$ or $|t| \geq 1.96$. 
In the nonadjacent nonmetropolitan counties, growth in nonbasic employment is not due to increased employment opportunities. The retirement variable has a significant and positive association with growth in nonbasic employment. While in the adjacent nonmetropolitan county models, the retirement variable has a significant and negative association with growth in nonbasic employment.

The influence of the wage rate variable on growth of nonbasic employment is a function of population size. In the larger metropolitan county models, there is a negative relationship between wages and growth in nonbasic employment. In the other county models, there is a positive association between wage rates and growth in nonbasic employment.

THE METROPOLITAN DIFFUSION MODEL

To test whether or not the movement to nonmetropolitan counties is a function of a spillover effect from the larger metropolitan counties to the exurban nonmetropolitan counties, all labor flows between metropolitan and their adjacent nonmetropolitan counties are excluded from the database.

Information is not available to determine whether these migrants commuted from the fringe to the metropolitan counties for work. However, the significance of the contiguous variable (movement between adjacent counties) in 
the large metropolitan counties is an indication of the possibility that employment moves from adjacent counties to the large metropolitan counties is a result of exurban commuting. The results of the $F$ test for the controlled adjacent model versus the uncontrolled model show statistically the coefficients are not equal. However, the differences in the parameter values vary slightly. For instance, the coefficient for basic employment increased from 0.006 to 0.011 ; the coefficient for nonbasic employment decreased from 0.023 to 0.015 . The coefficient for basic employment in the labor out-migration model controlling for proximity to metropolitan counties shows a decrease of -0.059 to -0.061 , and the nonbasic coefficient shows an increase from 0.002 to 0.006 .

Likewise, the effect of excluding labor flows between the large metropolitan counties and the adjacent nonmetropolitan counties show the beta coefficients are not equal. Again the parameter estimates show just slight differences (refer to Appendix B).

Table XXXV shows the movement between the spatial regions studied during the turnaround period. The significance of employment relocation in the Pacific states from metropolitan to nonmetropolitan counties appears to be somewhat overstated. A breakdown of labor migration by county type for the turnaround period reveals several things. First, the number one destination of labor migrants 
in the Pacific states continued to be the large metropolitan counties during the turnaround. Although more labor

migrants left metropolitan counties than moved to them during the turnaround, the large metropolitan counties were the destination for $70.95 \%$ of all labor migrants. The metropolitan regions with less than 500,000 residents received 14.038 of the labor migrants. The adjacent counties received $8.23 \%$ of the labor migrants and and the nonadjacent counties received $6.79 \%$ of the labor migrants.

\section{TABLE XXXV}

LABOR MIGRATION FLOW MATRIX BY ORIGIN AND DESTINATION COUNTY TYPES FOR THE STATES OF CALIFORNIA, OREGON, AND WASHINGTON, 1970-1975

\begin{tabular}{|c|c|c|c|c|c|}
\hline $\begin{array}{l}\text { COUNTY TYPE HIGRANT } \\
\text { HOVED FROH } \\
\text { (ORIGIN COUHTY) }\end{array}$ & $\begin{array}{l}\text { COUNTY TYPE } \\
\text { CDESTIHATION } \\
\text { LARGE } \\
\text { HETROPOLITAN } \\
>500,000\end{array}$ & $\begin{array}{l}\text { IIGRANT HOVED T } \\
\text { COUNTY) } \\
\text { SHALL } \\
\text { METROPOLITAN } \\
<500,000\end{array}$ & $\begin{array}{l}\text { ADJACENT } \\
\text { MOHHETRO- } \\
\text { POLITAN }\end{array}$ & $\begin{array}{l}\text { NON- } \\
\text { ADJACENT } \\
\text { NOHHETRO } \\
\text { POLITAH }\end{array}$ & $\begin{array}{l}\text { (ROW AND } X \\
\text { TOTALS REPRESENT } \\
\text { ORIGIN TOTALS) }\end{array}$ \\
\hline $\begin{array}{l}\text { LARGE METROPOLITAH AREAS } \\
\text { (POPULATION }>500,000)\end{array}$ & $\begin{array}{c}5478 \\
(76.91)^{\star} \\
(80.86)\end{array}$ & $\begin{array}{c}913 \\
(12.82) \\
(68.13)\end{array}$ & $\begin{array}{c}436 \\
(6.12) \\
(55.47)\end{array}$ & $\left|\begin{array}{c}296 \\
(4.16) \\
(45.68)\end{array}\right|$ & $\begin{array}{r}7123 \\
74.59\end{array}$ \\
\hline $\begin{array}{l}\text { SHALL HETROPOLITAN COUNTIES } \\
\text { (POPULATION }<500,000)\end{array}$ & $\begin{array}{c}748 \\
(62.59) \\
(11.04)\end{array}$ & $\begin{array}{c}189 \\
(15.82) \\
(14.10)\end{array}$ & $\begin{array}{c}149 \\
(12.47) \\
(18.95)\end{array}$ & $\left|\begin{array}{c}109 \\
(9.12) \\
(16.82)\end{array}\right|$ & $\begin{array}{r}1195 \\
12.50\end{array}$ \\
\hline ADJACENT NONMETROPOLITAN & $\begin{array}{c}288 \\
(45.79) \\
(4.25)\end{array}$ & $\begin{array}{c}142 \\
(22.58) \\
(10.60)\end{array}$ & $\begin{array}{c}83 \\
(13.20) \\
(10.56)\end{array}$ & $\begin{array}{r}116 \\
(18.44) \\
(17.90)\end{array}$ & $\begin{array}{r}629 \\
6.50\end{array}$ \\
\hline NOWADJACENT NONHETROPOLITAN & $\begin{array}{r}261 \\
(43.36) \\
(3.85)\end{array}$ & $\begin{array}{r}96 \\
(15.95) \\
(7.16)\end{array}$ & $\begin{array}{c}118 \\
(19.60) \\
(15.01)\end{array}$ & $\left|\begin{array}{c}127 \\
(21.10) \\
(19.60)\end{array}\right|$ & $\begin{array}{r}602 \\
6.30\end{array}$ \\
\hline $\begin{array}{l}\text { (COLUMN AND PERCENT } \\
\text { TOTALS REPRESENT } \\
\text { DESTINATIOA TOTALS) }\end{array}$ & $\begin{array}{r}6775 \\
70.95\end{array}$ & $\begin{array}{r}1340 \\
14.03\end{array}$ & $\begin{array}{r}786 \\
8.23\end{array}$ & $\begin{array}{r}648 \\
6.79\end{array}$ & $\begin{array}{r}9549 \\
100.00\end{array}$ \\
\hline
\end{tabular}


Most of the labor migrants from large metropolitan counties moved laterally to other large metropolitan areas (approximately 76.91\%). Just $10 \%$ of the large metropolitan labor out-migrants moved to nonmetropolitan counties (see Table XXXV). Most of the labor migrants from the smaller metropolitan counties moved to the large metropolitan counties (approximately 62.5\%). Twenty-one percent of the labor migrants from the smaller metropolitan counties moved to nonmetropolitan counties. Approximately $46 \%$ of the labor migrants from adjacent counties moved to the larger metropolitan counties. Forty percent of the adjacent county migrants moved to other nonmetropolitan counties. Approximately $31 \%$ of the adjacent nonmetropolitan labor migrants moved to other nonmetropolitan counties. Almost 43\% of the nonadjacent nonmetropolitan migrants moved to the larger metropolitan counties. Slightly over $40 \%$ of the nonadjacent labor migrants moved to other nonnetropolitan counties (see Table XXXV).

\section{SYMMETRY TESTS FOR IN- AND OUT-MIGRATION MODELS}

Because of the unexpected symmetry found in calibrating the migration models, the model results need to be checked for symmetry. To formally test whether or not the unexpected associations between labor in-migration, labor out-migration and the employment variables are statistically significant, a restricted model is tested by 
substituting the estimated parameters for basic employment, nonbasic employment and the migration variables in the labor out-migration with the estimated parameters from the labor in-migration model and vice versa.

The question of concern is whether the association occurs because areas that are destinations for migrants, as well as origins for migrants, are simply migration prone or whether the unexpected results are due to the rational assumptions behind migration modelling.

A reexamination of the migration literature indicates that the similarity in signs of the coefficients for labor in-migration and labor out-migration model results are not uncommon. Mueser (1987) indicates this unexpected association is frequently postulated as a result of a compositional effect: "areas that attract large numbers of migrant arrivals grow to have populations that are more migration prone, thus increasing the probability that an individual will depart" (p. 3). Mueser points out that the empirical tests of the compositional effects are not successful.

For this dissertation, the results of the restricted models are tested by applying a $\underline{F}$ test to determine whether the differences between the in-migration and out-migration models are statistically significant. A maximum likelihood ratio is the more preferred test. However, due to limitations of the SAS statistical software package released 
by the SAS Institute a $\underline{F}$ test was substituted. The $\underline{F}$ test yields similar results to the maximum likelihood ratio tests.

The $F$ tests show that the beta coefficients are not equal in the labor in-migration and labor out-migration models calibrated (refer to Appendix c). There are significant differences between the restricted and unrestricted models for the labor in-migration and labor out-migration models.

\section{CHAPTER SUMMARY AND CONCLUSIONS}

The calibration results of the labor migration models reaffirm the causality problems that are encountered in migration modelling. F tests of whether the coefficients are equal for the three periods studied show that there are significant differences in the coefficients in the two pre-turnaround and turnaround models.

Most of the model calibration results show that basic employment has a negative association with both labor in-migration and labor out-migration, whereas nonbasic employment growth tends to have a positive association with both labor in-migration and labor out-migration.

The data results show that although several of the environmental amenity and disamenity variables have a statistically significant effect on labor in-migration, the relative effect of the environmental amenity and disamenity 
variables (as measured by the beta coefficients which show the elasticity of response of the particular variable), is small, with the exception of the income, housing, and crime index variables.

The relative effect of basic and nonbasic employment variables on labor migration is higher than most of the environmental amenity or disamenity variable effects. The relative effect of labor out-migration and labor in-migration on employment is equally high. The calibration results for the metropolitan county models are different than the nonmetropolitan county calibrations. The metropolitan county model calibrations show that the environmental disamenity variables have a much greater influence in the larger metropolitan counties than they have in the nonmetropolitan counties. The wage rate variable is negatively associated with growth in employment in the larger metropolitan calibrations, whereas the wage rate variable has a positive association with employment growth in the nonmetropolitan counties. 
CHAPTER VI

CONCLUSIONS: THE IMPLICATIONS

OF THE MODELS

The purpose of this study has been to examine the determinants of labor force migration patterns and their interrelationships with economic deconcentration in the context of the nonmetropolitan turnaround in the 1970s. The study achieves this goal by developing a system of simultaneous equations to test labor migration flows' response to the environment, accessibility factors, and economic activities. Although the model results are not always in the hypothesized direction, the calibration results do reflect structural differences in the pre-turnaround and turnaround model results.

This chapter synthesizes the research findings of this study of labox migration with the research findings on population migration reported in the scholarly literature. The first section presents an overview of the empirical findings of the research models. The second section discusses the research hypotheses in the context of the nonmetropolitan turnaround. The third section compares the results of the labor models with the findings reported in the literature for the population models. The fourth section presents some limitations of labor migration studies 
and the data limitations encountered when studying labor migration.

\section{RESEARCH FINDINGS}

The scholarly literature indicates that the metropolitan/nonmetropolitan turnaround is a clean break with past migration behavior (Berry, 1976C, 1980; Vining \& Strauss, 1977). This break furthermore is not unique to U.S. migration flows, but widespread in the developed world. Migration flows supposedly cascade down the size hierarchy of cities. The basis of this hypothesis emerges from the core-periphery studies in international settlement systems (Vining \& Kontuly, 1978; Vining \& Pallone, 1982). However, Vining and Kontuly, and strauss's regional definitions are so broadly based (i.e., Northeast, Midwest, South, and West) that the subregional differences within the regions are overlooked.

An alternative hypothesis to the clean break hypothesis is the period hypothesis that the nonmetropolitan turnaround results from a set of "unique economic and demographic circumstances that converged in the 1970s" (Frey, 1988, p. 262). For instance, the recession of 1973-1974 reduced the ability of the large metropolitan areas to generate jobs, thus leading to numerous economic dislocations and de-industrialization of investments from the larger metropolitan regions. These events supposedly 
led to a core-periphery shift in U.S. migration flows that enhanced the growth in manufacturing in the nonmetropolitan counties located in the western and southern peripheries of the United States.

Two hypotheses have been put forth in the scholarly literature as to why the turnaround of jobs and people happened in the United States during the 1970s. One viewpoint is that the turnaround occurred as a result of a population deconcentration process. The other viewpoint is that the turnaround is a result of regional restructuring (Frey, 1988).

The population deconcentration viewpoint links changes in technology and production with residential choice. Wardwell (1980) concludes that residential space-flexibility due to changes in technology and economic institutions allow residents to take advantage of their pent-up residential preferences toward low density locations.

Regional restructuralists view economic dislocations as a short-term de-industrialization episode that leads to a new spatial organization of production (Bluestone \& Harrison, 1982; Castells, 1985; Frey, 1987, 1988; Noyelle \& Stanbach, 1984). Regional restructuring leads to two regional phenomenon. The first is process by which new industrial centers emerge that will facilitate the expansion of nonroutine manufacturing firms into world markets, the improvement of communication systems and production 
technologies and the attraction of multinational

headquarters. The second process leads to a shift of routine manufacturing away from large metropolitan areas to smaller metropolitan and nonmetropolitan counties (Frey, $1987,1988)$.

This study's research findings show that there are significant structural differences in labor migration flows in the pre-turnaround and turnaround models tested. The $\mathbf{F}$ test for equality of coefficients show significant differences in the spatial regions studied. However, the model results show several unexpected results. These unexpected results show the turnaround in the Pacific states is far more complex that the regional development literature suggests.

It is evident from the economic development and demographic literatures that the complexity of the economic and demographic changes in the 1970 s requires examining the link between residential preferences and structural change in the labor markets. The 1970s witnessed the impact of three major structural changes on U.S. human settlement patterns: economic de-industrialization (resulting from a worldwide economic crisis that led to heavy disinvestment in economic activities in the larger U.S. metropolitan regions [Bluestone \& Harrison, 1982]), economic restructuring (an ongoing economic process that evolved from technological innovations in production, transportation and communications 
allowing for greater flexibility in location [Frey, 1987; Noyelle \& Stanbach, 1984]), and population deconcentration (a gradual, bidt sustained shift of population away from large metropolitan regions to smaller regions [Wardwell, 1980]). Each of these social and economic forces leads to different spatial outcomes.

Part of the unexpected results of this study might be attributed to the economic deconcentration process in the Pacific states. As mentioned in the previous chapter, the deconcentration process in the Pacific states is not one in which metropolitan growth spilled over into the nonmetropolitan counties. Both the Pacific metropolitan and nonmetropolitan counties simultaneously experienced de-industrializing (a decline of manufacturing employment and growth of service employment).

In absolute numbers, in the 1960s, the large metropolitan areas had a net gain of labor migrants. But in the 1970s, the large metropolitan areas had a small net loss of labor migrants. It should be pointed out this does not reflect a massive labor out-migration from metropolitan regions, but rather reflects a gradual, not abrupt change in labor migration flows.

Table XXXVI summarizes this study's research hypotheses in the context of labor force migration patterns found in the Pacific states during the nonmetropolitan turnaround period. 
TABLE XXXVI

THE DIFFERENCE BETWEEN THE EXPECTED AND

THE ACTUAL RELATIONSHIP OF SPECIFIED

VARIABLES WITH LABOR MIGRATION

\begin{tabular}{|c|c|c|c|c|c|c|}
\hline & \multicolumn{2}{|c|}{ IN-HIGRATIOH } & \multicolumn{2}{|c|}{ OUT-MIGRATIOH } & \multicolumn{2}{|c|}{ MAGNITUDE } \\
\hline & Expected & Actual & Expected & Actual & Expected & Actual \\
\hline \multicolumn{7}{|l|}{ MONADJACENT } \\
\hline Amenity & + & $+1-$ & - & + & Large & Small \\
\hline Disomenity & - & $+1-$ & + & $+1-$ & Smoll & Small \\
\hline Accessibility & $+1-$ & $+1-$ & $+1 \cdot$ & $+/-$ & Large & Large \\
\hline Basic Employment & + & $\therefore$ & - & - & Small & Small \\
\hline Nonbas ic Employment & + & - & - & + & Small & Small \\
\hline \multicolumn{7}{|l|}{ ADJACEHT } \\
\hline Amenity & + & - & - & $+1-$ & Large & Small \\
\hline Disamenity & - & $+/-$ & + & $+1-$ & Small & Small \\
\hline Accessibility & + & + & + & + & Large & Large \\
\hline Basic Employment & + & + & - & - & Small & Small \\
\hline Honbas ic Empl oyment & + & + & - & - & Small & Small \\
\hline \multicolumn{7}{|l|}{ METRO $<500,000$} \\
\hline Amen ity & + & - & - & $+/-$ & Small & Small \\
\hline Disemenity & - & $+1-$ & + & $+1-$ & Small & Smali \\
\hline Accessibility & + & +1 & $+1-$ & $+1-$ & Large & Smali \\
\hline Basic Employment & + & $\cdot$ & - & $\therefore$ & Large & Small \\
\hline Nonbasic Enployment & + & - & - & + & Large & Small \\
\hline \multicolumn{7}{|l|}{ METRO $>500,000$} \\
\hline Amenity & + & $+1-$ & - & $+/-$ & Small & Small \\
\hline Disamenity & - & $+1-$ & + & $+1-$ & Large & Small \\
\hline Accessibility & + & $+1-$ & $+1-$ & $+1-$ & Large & Small \\
\hline Basic Employment & + & - & - & - & Large & Small \\
\hline Honbesic Employment & + & + & - & + & Large & Small \\
\hline
\end{tabular}

\section{A GROWING IMPORTANCE OF ENVIRONMENTAL AMENITIES AND ENVIRONMENTAL DISAMENITIES}

It has been hypothesized that environmental amenities and disamenities play a significant role in attracting labor migrants to nonmetropolitan counties. As mentioned previously, Stevens (1980) indicates migrants were willing to sacrifice income for amenities in the 1970s. This study attempted to examine whether there was a significant association between labor in-migration and the environmental amenity and disamenity variables in the three Pacific states 
during the turnaround period. The following section discusses the influence of the environmental amenity and disamenity variables on labor migration flows in the spatial regions studied.

\section{Nonadjacent Nonmetropolitan}

Counties

In the nonadjacent nonmetropolitan counties, just one environmental amenity variable, four year college enrollment, has a positive and highly significant association with labor migration during the turnaround period at the $95 \%$ level of confidence. The recreational opportunity variable has a positive association with labor in-migration flows in the 1970-1975 model, but the level of significance is just $90 \%$. For the most part, the empirical results support Wardwell's (1980) hypothesis that part of the growth in metropolitan counties was the changing employment structure, which allowed nonmetropolitan residents to live in their preferred residential environment.

Adjacent Nonmetropolitan Counties

Environmental amenities and disamenities are not a major pull or push factor for labor migration flows in the adjacent nonmetropolitan county models. Most of the environmental amenities variables have an insignificant or negative relationship with labor in-migration flows to the 
adjacent nonmetropolitan county model results. The only environmental disamenity variable that has a significant and negative association with lahor in-migration flows is the age dependency variable. And only one environmental disamenity variable has the expected significant and positive association with labor out-migration flows (the crime index).

\section{Smaller Metropolitan Counties}

Environmental amenities have a minor influence on labor migration flows to the smaller metropolitan counties. Just the recreational amenity variable has a significant influence on labor migration flows during the turnaround period. Environmental disamenities, on the other hand, have a significant influence on labor in-migration flows. However, the results are unexpected. Just the crime index has the expected, negative association with labor in-migration flows, whereas age dependency, climate, and housing have a positive and significant influence on labor in-migration flows.

\section{Larger Metropolitan Counties}

Environmental amenities have no significant influence on labor in-migration flows to the large metropolitan counties. Urban environmental disamenities are frequently mentioned in the scholarly literature as a major determinant of population deconcentration (Alonso, 1976; Berry, 1976a). 
The model results for the metropolitan counties show some support of the disamenities hypothesis. In the turnaround period, most of the disamenity variables show the expected negative relationship with labor in-migration flows, except for the crime rate variable.

\section{THE DECLINING IMPORTANCE OF} UNEMPLOYMENT

Although job related reasons are frequently cited as the major motive for relocating, this study finds employment potential (the proxy variable for unemployment) does not act as a push variable in the labor out-migration models. Even though the results found in this study are consistent with the recent economic development literature, it should be noted that part of the reason why this variable is not that important could be the inability to accurately measure the "real" level of unemployment.

Evidence from worker relocation programs show little success in relocating the unemployed worker. In general, place attachment is a strong deterrent to labor out-migration. Only $11 \%$ of the displaced workers in the federal job assistance network program in mid-willamette Valley moved to new labor markets. The majority of those workers who moved were the younger, better educated workers (Office of Technology Assessment, 1986, p. 261). 


\section{DECLINING INCOME DIFFERENTIALS}

OVER TIME

Another primary motive for labor migration identified in the migration literature is the search for economic gain, which has traditionally been equated with increases in monetary income. To test whether relative income in a county is a primary motive for labor migration, this study operationalized income gain as the ratio of median income in a particular county over the median income of the United States. The research hypothesis, therefore, is whether relative income differentials are positively related to labor in-migration and negatively related to labor out-migration.

The model results for testing the income differential variable is ambiguous. In the nonadjacent nonmetropolitan, adjacent nonmetropolitan and small metropolitan county models, the influence of income differentials on labor migration is limited, if not spurious, since several of the coefficients have either an unexpected sign or have a coefficient that is not statistically significant at the $95 \%$ level of confidence. In the larger metropolitan county labor out-migration models, the income differential variable has a negative and significant association with labor out-migration flows as expected. But in the larger metropolitan labor in-migration models, the income 
differential variable has a positive, but insignificant association with labor in-migration flows.

THE INFLUENCE OF SPATIAL INTERACTION

As mentioned in previous chapters, the assumption of the spatial interaction models is that the flow of migration between two regions is associated with the spatial interaction of the two regions and inversely related to the distance between the two regions. The labor potential index in this dissertation is a measure of the spatial interaction between labor markets. The influence of the labor potential index is positive. The results of this dissertation do not show a declining effect of distance on the interaction between counties in the Pacific states. In fact, the calibrations for the distance coefficient show little variation in the distance elasticity coefficient for the three periods studied (see Appendix A).

\section{DIFFERENTIAL IMPACTS OF ECONOMIC DECONCENTRATION}

This study uses the availability of employment activities as the operational measurement for the search for economic opportunities. The employment opportunities variables compare the relative share of employment in an industrial sector with the rest of the nation. The research hypothesis examined for this study is that economic 
opportunities as measured by employment activities are negatively associated with labor in-migration and positively associated with labor out-migration.

Previous research indicates increased employment opportunities are a function of two economic processes, restructuring of employment from manufacturing to a service based economy and de-industrialization. To test the importance of restructuring and de-industrialization of production activities in the large metropolitan regions, this study has examined the relationship between basic and nonbasic employment growth with labor force migration. Basic employment is categorized into the following industrial sectors: rourine manufacturing, non-routine manufacturing, agriculture, and producer services. The inclusion of producer services within the basic employment sectors rather than nonbasic employment sectors is a result of the linkages between manufacturing industries and producer services identified in the economic development literature.

Markusen (1985) indicates that much of the decline in manufacturing is a result of subcontracting or out-sourcing of traditional manufacturing activities to the producer service sectors.

This study finds the impact of this restructuring and de-industrialization varies according to a region's proximity to metropolitan regions. 


\section{Nonadjacent Counties}

Employment activities have no significant influence on labor in-migration to nonadjacent nonmetropolitan counties. But labor out-migration has a negative and significant association with growth in basic employment.

Labor migration itself has a significant and positive influence on growth in basic employment. Basic employment growth is not a function of metropolitan de-industrialization, but a function of restructuring within the nonadjacent nonmetropolitan counties. Basic employment growth results from increases in employment activities for producer services. This lends some support to Heaton and Fuguitt's (1979) hypothesis that services played a major role in the nonmetropolitan turnaround in the nonadjacent nonmetropolitan counties.

Growth in nonbasic employment is function of the presence of population over 65 and wage rates in the nonadjacent nonmetropolitan counties. Labor migration has a limited, if not spurious influence on growth in nonbasic employment. The employment opportunities variables for personal service and retail trade and government have an insignificant association with growth in nonbasic employment.

\section{Adjacent counties}

In the adjacent nonmetropolitan counties, employment activities have no significant influence on labor 
in-migration flows to the adjacent nonmetropolitan counties. However, labor in-migration shows an unexpected negative influence on growth in basic employment in the adjacent nonmetropolitan model results. However, labor in-migration shows the expected positive influence on growth in nonbasic employment.

The hypothesis that employment growth in the adjacent nonmetropolitan counties is a function of the increased diversity of employment activities in services does appear to be the case. In the 1970s, as employment in manufacturing declined in the adjacent nonmetropolitan counties, employment in producer services increased. The model results further support this hypothesis. Employment opportunities in producer services have a significant association with growth in basic employment. The variables for routine manufacturing and agricultural services, on the other hand, have a negative influence on growth in basic employment activities.

Accessibility as measured by the presence of interstate freeways has a major influence on growth in basic employment.

Growth in nonbasic employment in the adjacent nonmetropolitan counties is associated primarily with labor in-migration, growth in basic employment, and wage rates. 
The model results for the adjacent counties show a symbiotic relationship between basic and nonbasic employment growth.

\section{Smaller Metropolitan Areas}

The empirical results show the importance of nonroutine manufacturing for growth in basic employment activities in the smaller metropolitan counties. However, as nonroutine manufacturing has grown in importance in the larger metropolitan regions, routine manufacturing has declined in importance in the smaller metropolitan regions. other employment activities, such as agricultural services and producer services also have a significant association with growth in basic employment.

\section{Larger Metropolitan Areas}

It is evident from the empirical results for the large metropolitan statistical areas that labor in-migration is quite responsive to employment decline in basic employment and employment growth in nonbasic employment.

The empirical results show that in the large metropolitan areas of the Pacific states, basic employment growth is associated with employment activities in nonroutine manufacturing and producer services in the 1960s. In the 1970s, the Pacific states, especially the state of California, have become centers for nonroutine production activities such as aerospace, defense, electronics, and 
other advanced technology industries. This growth in nonroutine manufacturing activities has been instrumental in the restructuring of the Pacific region's economic base. Nonroutine manufacturing is positively associated with basic employment in the larger metropolitan areas, whereas routine manufacturing is negatively associated with basic employment.

The large metropolitan regions continue to benefit from urban service agglomerations. The nonbasic employment sectors (i.e., retail and government services) have a significant influence on nonbasic employment growth in all periods. Unlike the rest of the nation, agricultural services still play a major role in the metropolitan economies of the Pacific states.

HIGHER WAGES STIMULATE NONMETROPOLITAN GROWTH: LOWER WAGES STIMULATE METROPOLITAN GROWTH

A major stimulus to employment redistribution mentioned in the turnaround literature is relatively low wage rates in nonmetropolitan counties. For example, Kasarda (1988) cites relatively low wage rates as a push factor for basic employment growth in the 1970s. This study finds basic employment growth in the 1970 s has a positive relationship to high wage rates in nonmetropolitan areas.

The above symmetry of results do not support Thompson's (1975a) spatial filtering hypothesis. As previously mentioned, Thompson argues that economic 
deconcentration is a result of filtering down the national hierarchy of cities from regions of high skilled labor, high wages to regions of low skilled, low wages. There is evidence of filtering from high skilled to low skilled areas, but not filtering down from high wage to low wage areas. As discussed previously, nonroutine manufacturing and producer services are the most significant employment activity in metropolitan regions, while producer services are the most significant basic employment activity in the nonmetropolitan counties.

The unexpected results for the wage rate variables are not unique to the Pacific region. Norcliffe (1984) finds a similar pattern in Canada and Great Britain for nonmetropolitan regions. There is a debate, however, in the scholarly literature whether these higher wages are a proxy measure of residential amenities in nonmetropolitan regions.

According to scott (1980), the decentralization

process of capital intensive firms is

- . the consequence of their search for cheap land inputs in the context of diminished locational constraints on the capital side combined with escalating wage rates in the urban periphery. (p. 107)

\section{A RECONFIGURATION OF CENTRAL PLACE ACTIVITIES}

The literature review indicates that economic deconcentration facilitates a spatial reconfiguration of central place activities. In part, this is a consequence of 
a post-industrial restructuring from a manufacturing based economy to a service based economy, which leads to a decline in industrial agglomeration. Thompson (1975a) suggests the decline of industrial agglomeration "left us with a large number of overgrown cities" (p. 189). Thus, the employment decline in the larger metropolitan areas should not be a surprise.

To test the functional expansion or decline of central place activities hypothesis requires examining the changing economic structure of basic and nonbasic employment. If central place activities are spatially reconfigurating, it would thus follow that producer, personal and retail services are positively related to employment in the smaller metropolitan and nonadjacent regions. The empirical evidence shows that producer and retail services in large metropolitan areas continue to be positively associated with employment. Likewise, the producer service variables are positively related to employment growth in the smaller metropolitan, adjacent nonmetropolitan and nonadjacent nonmetropolitan counties.

There does not appear to be evidence that the central place activities are spatially reconfigurating in the nonmetropolitan counties in the Pacific states. The personal services and retail trade variables are less important in the smaller metropolitan, adjacent 
nonmetropolitan and nonadjacent nonmetropolitan county models than in the metropolitan county models.

\section{THE IMPORTANCE OF RETIREMENT}

The hypothesis that retirement has a major impact on nonbasic employment growth is supported in the nonadjacent nonmetropolitan county models, but the hypathesis is not supported in the adjacent nonmetropolitan county model results. This relationship has become more significant over time in the non-adjacent nonmetropolitan counties.

\section{THE IMPORTANCE OF ACCESS}

Increased access plays a major role in stimulating economic development. The presence of the interstate freeways in nonmetropolitan areas allows for easier movement of goods and services in nonmetropolitan areas. The federal highway administration finds that improved transportation facilitates economic development in rural remote regions. The results for all of the spatial models tested in this study show support for the access hypothesis.

A COMPARISON OF THE LABOR FLOW MODELS WITH THE GENERAL POPULATION FLOW MODELS

Even though the non-working population, such as the youth who are entering the labor force and the elderly who are leaving the labor force, is excluded from the database, the results of the labor model estimation are not 
inconsistent with the population flow models reported in the literature review.

Environmental pull variables tend to exert a significant influence on labor in-migration in both flow models. However, the magnitude of the estimated parameters is small. A major labor and population flow models the influence of four-year colleges on labor migration. Fuguitt, Voss, and Doherty's (1979) study on nonmetropolitan growth found in-migration is positively associated with college enrollment. This study finds that college enrollment does have a significant positive association with labor in-migration in the nonadjacent nonmetropolitan county models, but not in the adjacent nonmetropolitan county model results. The large metropolitan county models also show a significant relationship between four year college enrollment and labor in-migration. The variables for recreational opportunities in the nonadjacent nonmetropolitan country modes also show a positive association with migration, but the association is significant only at the $90 \%$ level.

Labor force in-mjgration is less responsive to the economic health variables. This study finds that the economic health variables, as measured by unemployment, income differentials and housing cost, show limited influence on labor migration to nonmetropolitan counties. 
Another difference with this study and some of the economic development literature is that this study finds a positive association between wage rates and growth in employment in the nonmetropolitan counties.

The population and labor flow models show more comparable results in the large metropolitan areas. Both the population and labor flow models show a negative relationship between urban disamenities and labor in-migration. Another similarity is the negative association between wage rates and employment growth.

\section{LIMITATIONS OF THE LABOR FLOW MODELS}

The research model tested whether the neoclassical economic, human ecological and spatial theories could be integrated into a comprehensive labor flow model. The numeric representation of the model examined labor migration as a function of economic activities, the environment, and accessibility. The labor flow model tested in this study accomplishes this task. All of the specified equations are statistically significant. However, some of the estimated parameters are not as anticipated. For instance, labor out-migration shows a positive association with employment in several of the model calibrations. Employment growth also has an unexplained positive association with labor out-migration. 
Only in the larger metropolitan counties does employment growth in the basic sector have the expected negative relationship with labor out-migration during the turnaround period. The labor out-migration estimated parameters are either insignificant or positive in the turnaround models. Growth in non-basic employment, however, shows an expected relationship with out-migration, except in the 1970-1975 metropolitan area model.

The estimated signs for labor in-migration are almost identical to the labor out-migration calibrations. only in the 1960-1965 model does the calibration results for labor in- and out-migration have the opposite results.

This study attempted to test formally the symmetry hypothesis for labor migration. The hypothesis tests for symmetry are rejected. The symmetry tests show that the coefficients for labor in-migration and labor out-migration in the Pacific states are not equal.

A major problem with the labor migration models is the underlying assumptions of migration models. The results for the aggregate ecological models reported in the population turnaround literature encounter the same problems as the neoclassical economic models. The aggregate net migration models distort the impact of structural change at the origin and destination points and do not really show the magnitude of the response to migration change in the structure of an organization (Pol, Schafer, \& Sly, 1984). Pol, Schafer, and 
sly developed an ecological model that recognizes that migration and ecological structure is more complex than originally perceived. Their work disaggregated the flow of migration into the south according to the in- and out-components of the migration flows. The rationale of the approach is that in- and out-flows ". . are themselves demographic processes and as much should be influenced by the structural conditions operating in ecological systems" (pp. $2-3$ )

Another flaw in migration modelling is the assumption that out-migration is a rational act. Ballard and clark's (1981) study of inter-state migration flows found labor in-migration is responsive to economic conditions, but their results show no symmetry between laborers who out-migrated from "depressed" regions and laborers who in-migrated to "growing regions" (p. 227). This study finds similar results, labor in-migration is responsive to a few of the environmental amenities but not responsive to employment opportunities at the destination, while labor out-migration is responsive to employment opportunities. The most consistent result in the model calibrations is the response of labor migration flows to the accessibility variables. Both the ecological and economic models are based on equilibrium models. The economic assumptions are derived from Adam Smith's competitive market assumptions, which assert there are no barriers for capital and labor mobility 
(cited in Clark, 1983). Labor migrants are economically rationale consumers seeking to maximize their economic opportunities. Isard (1960) states that there are spatial market imperfections. Information does not flow freely from one area to another. Labor migrants are not always aware of economic opportunities in other regions, especially in the nonadjacent nonmetropolitan areas.

\section{FURTHER COMMENTS--BARRIERS} TO MOBILITY

The limitation of the labor flow model affirm the complexity of migration modelling. In general, the literature review discusses several weak points in the ecological and neoclassical models. Both the ecological and neoclassical models are macro models, which fail to address the issues of cultural values and motivation in migration. Individuals have strong place attachment to their current environment. In the Pacific nonmetropolitan counties, the economic culture has evolved around the resource based industries, such as lumber, agriculture and mining. Even when there occurs a decline in lumber production leaving limited employment alternatives, workers do not always move away (Hibbard, 1989).

Without an understanding of the cultural context of the individual, one cannot evaluate the micro and macro linkages in the environment. Dejong (1984) contends migration research needs to evaluate how micro and macro 
linkages relate to the individuals perception of the environment. For instance, the literature review notes three primary motives for migration: employment, amenities, and social factors. This study, due to the limitations of the database, does not address the link between social factors and employment and amenities. Moving is a stressful life event, which incurs both monetary, psychic, and social costs. Those most prone to economic stress are the least likely to move. Generally, there are several social and economic deterrents to labor migration, such as:

1. Structural Disequilibrium. A major barrier to moving appears to be the structural disequilibrium in the economic base. Most nonmetropolitan counties in the Pacific Northwest and northern California are dependent on lumber based industries. Thus their economies are subject to cyclical employment opportunities. The cyclical and long-term nature of the lumber industry is regionwide, leaving unemployed millworkers with few opportunities in the region for employment.

2. Location Specific Capital. Another barrier to mobility is "location-specific" capital, such as long-term residency and home-ownership. Williams and McMillen's (1983) found the migrants with dense social networks are less likely to move. In addition, the greater the commitment an individual has to his occupational, social and organizational involvement, the less likely the individual 
is willing to relocate. The CWHS (U.S. Economic, 1976a)

data reflect that labor migrants who leave the

nonmetropolitan areas are younger than those who remain behind.

3. Previous Exposure to the Environment. The preference literature cites that experience or exposure to a particular environment increases the likelihood an individual will relocate. The single most preferred residence is a person's current residence. Previous experience in an environment; such as childhood experience, travel, or prior mobility; enables an individual to decide about the qualities of a particular community (zuiches, 1981).

\section{DATA LIMITATIONS}

The unexpected findings of the labor flow model and the lack of not addressing the linkages between social factors and the broader structural environment point to the need for research in nonmetropolitan areas to focus not just on the macro area, but on the micro decision of labor migration as well. There is a need to combine aggregate secondary data with qualitative data. The secondary data allow the researcher to generalize to larger regions. However, the aggregation does not allow the researcher to examine the uniqueness of growing or declining areas. 
Although the model calibrations for this study have high coefficients of determinations, there remain several unanswered questions. Part of the problem is the cost involved in collecting primary data, which is derived from a reliance on data collected by public agencies for population count.s, rather than data collected to study a social phenomenon such as labor migration.

The major limitation is the paucity of available secondary data. The Census long form (the Public Use Micro Sample) provides detailed information on individual characteristics, but lacks the necessary spatial information for origin destination models (Isserman, Plane, \& McMillen, 1982). The annual Current Population Survey provides information on such migration characteristics as age, gender, and occupation, but it is reliable only for the census regions (Isserman, Plane, \& McMillen, 1982). The Internal Revenue Service data provides only limited information on individual characteristics at the state and county level (Isserman, Plane, \& McMillen, 1982). Few of these data sets provide information on areal characteristics, such as amenities and employment opportunities, within individual counties. This study was able to merge various areal characteristic with information on migrant characteristics to study the areal characteristics that attracted labor migrants during the turnaround. But the data limitations did not allow 
determining the difference in labor migration patterns by race, marital status, level of education, labor force status, and presence of children. This presents a problem when one desires to examine both the determinants of the destination county and the determinants of the origin county. 


\section{REFERENCES}

Alonso, w. (1976, May/June). Urban disamenities. Society, 4, 51-53.

Armstrong, R. (1972). The office industry. Cambridge: MIT Press.

Ballard, K. P., \& Clark, G. L. (1981). The short-run dynamics of inter-state migration: A space-time economic adjustment model of in-migration to fastest growing states. Regional Studies, 15 (3), 213-228.

Ballard, P. L., \& Fuguitt, G. V. (1985). The changing small town settlement structure in the United States, 1900-1980. Rural Sociology, 50 (1), 99-113.

Bartel, A. (1979, December). The migration decision: What roles does job mobility play? American Economic Review, 69, 775-786.

Beale, C. J. (1975). The revival of papulation growth in nonmetropolitan America (ERS-605). Washington DC: United states Department of Agriculture, Economic Research Service.

Beale, C. J. (1976). A further look at nonmetropolitan population growth since 1970. American Journal of Agricultural Economics, $\underline{58}$ (5), 953-958.

Beale, C. J. (1977). The recent shift of the United states population to nonmetropolitan areas, 1970-75. International Regional Science Review, 2 (4), 113-122.

Beale, C. J. (1980). The changing nature of rural employment. In D. L. Brown \& J. M. Wardwell (Eds.), New directions in urban-rural migration: The population turnaround in rural America (pp. 37-50). New York: Academic Press.

Beale, C. J., \& Fuguitt, G. V. (1978). The new pattern of nonmetropolitan population change. In K. E. Taeuber, L. L. Bumpass, \& J. A. Sweet (Eds.), Social demography (pp. 157-177). New York: Academic Press. 
Beauregard, R. A. (1989). Economic restructuring and political response. Newbury Park, CA: Sage Publications Urban Affairs Annual Reviews.

Bender, L. P. (1980). The effect of trends in economic structures of population change in rural America. In D. Brown \& J. J. Wardwell (Eds.), New directions in urban and rural America: The population turnaround in rural America (pp. 137-162). New York: Academic Press.

Bender, L. P. (1985). The diverse social and economic structure (Rural Development Research Report No. 49). Washington, DC: United States Department of Agriculture.

Berry, B. J. (1976a, May/June). Aging metropolis in decline. Society, 4, 54-56.

Berry, B. J. (1976b) : The counterurbanization process: Urban America since 1970. In B. J. Berry (Ed.), Urbanization and counterurbanization (pp. 17-30). Beverly Hills: Sage Publications.

Berry, B. J. (Ed.) (1976c). Urbanization and counterurbanization. Beverly Hills, CA: Sage Publications.

Berry, B. J. (1977). The changing shape of metropolitan America. Cambridge: Ballinger Publishing.

Berry, B. J. (1978). The counterurbanization process: How general? In N. M. Hansen (Ed.), Human settlement systems (pp. 25-49). Cambridge: Ballinger Publishing.

Berry, B. J. (1980). Urbanization and counter-urbanization in the United States. In R. D. Lambert \& A. W. Heston (Eds.), Changing cities: A challenge to planning, Vol. 451 (pp. 13-20). Philadelphia: American Academy of political Science.

Berry, B. J., \& Kasarda, J. P. (1977) . Contemporary urban ecology. New York: MacMillan Publishing Company.

Blanco, C. (1963). The determinants of interstate population movements. Journal of Regional science, $\underline{5}$ (1), 77-84.

Blanco, C. (1964). Prospective unemployment and interstate population movements. Review of Economics and Statistics, 46 (2), 221-222. 
Bluestone, B., \& Harrison, B. (1982). The deindustrialization of America. New York: Basic Books.

Borts, G. H. (1960, June). The equalization of returns and regional growth. The American Economic Review, 50, 319-347.

Borts, G. H., \& Stein, J. L. (1964). Economic growth in a free market. New York: Columbia University Press.

Bradbury, K. L., Downs, L. A., \& Small, K. A. (1982). Urban decline and the future of American cities. Washington, DC: Brookings Institute.

Brewer, M. (1981). The changing U.S. farmland scene. Population Bulletin, $\underline{36}$ (3), 3-39.

Briggs, V. M. (1981) . Unemployment and underemployment. In A. H. Hawley \& S. M. Mazie (Eds.), Nonmetropolitan America in transition (pp. 359-381). Chapel Hill: The University of North Carolina Press.

Brown, D. L., \& Beale, C. (1981). Diversity in post-1970 population trends. In A. H. Hawley \& S. M. Mazie (Eds.), Nonmetropolitan America in transition (pp. 27-71). Chapel Hill: The University of North Carolina Press.

Brown, D. L., \& Wardwell, J. W. (1980). New directions in urban-rural migration: The population turnaround in rural America. New York: Academic Press.

California Department of Employment Development, Employment Data and Research Division. (1965). California labor market bulletin. Sacramento: Author.

California Department of Employment Development, Employment Data and Research Division. (1970). California labor market bulletin. Sacramento: Author.

California Department of Employment Development, Employment Data and Research Division. (1975). California labor market bullerin. Sacramento: Author.

California Department of Parks and Recreation. (1979). Recreation outlook in planning districts: An element of the california outdoor recreation resources plan. Sacramento: Author.

California State Census Data Center. (1965). Population Figures. Sacramento: Department of Finance. 
California State Census Data Center. (1975). Population Figures. Sacramento: Department of Finance.

Carpenter, E. H. (1977). The potential for population dispersal: A closer look at residential location preferences. Rural Sociology, 42 (3), 352-370.

Carpenter, E. H. (1980). Retention of metropolitan-tononmetropolitan labor-force migrants. In D. L. Brown \& J. M. Wardwell (Eds.), New directions in urban-rural migration: The population turnaround in rural America (pp. 213-227). New York: Academic Press.

Carrothers, G. A. P. (1956, spring). A historical review of gravity models and potential concepts of human interaction. Journal of the American Institute of Planners, 22, 94-102.

Castells, M. (1977). The Urban Question. Cambridge: MIT Press.

Castells, M. (1985). High technology, space and society. Beverly Hills, CA: Sage Publications Urban Affairs Annual Reviews.

Cebula, R. J., \& Vedder, R. K. (1973). A note on migration, economic opportunity, and the quality of life. Journal of Regional Science, 13 (2), 205-210.

Center for Continuing study of the California Economy. (1982). Recreation activity in California and ten regions of the state. Palo Alto: Author.

Center for Population Research and Census. (1965). population estimates 1965. Portland, OR: Portland State University.

Center for Population Research and Census. (1975). Population estimates 1975. Portland, OR: Portland State University.

Chalmers, J. A., \& Greenwood, M. J. (1977). Thoughts on the rural to urban migration turnaround. Internal Regional Science Review, $\underline{2}$ (2), 167-170.

Champion, A. (1989). Counterurbanization: The changing pace and nature of population deconcentration. London: Edward Arnold.

Christ, C. F. (1966). Econometric models and methods. New York: John Wiley and Sons, Inc. 
clark, G. (1981). The employment relation and spatial division of labor: A hypothesis. Annals of the Association of American Geographers, 71 (3), 412-424.

Clark, G. L. (1982). Volatility in the geographical structure of the short-run U.S. interstate migration. Environment and Planning A, 14 (2), 145-167.

Clark, G. (1983). Interregional migration, national policy and social justice. Totowa, NJ: Rowman and Allanheld.

Clark, G. L., \& Ballard, K. P. (1980). Modeling out-migration from depressed regions: The significance of origin and destination characteristics. Environment and Planning A, 12 (7), 799-812.

Clark, G., Gertler, M. S., \& Whiteman, J. (1985). Regional dynamics: studies in adjustment theory. Boston: Allen and Unwin.

clifford, W. B., Heaton, T. B., Lichter, D. T., \& Fuguitt, G. V. (1983). Components of change in the age composition of nonmetropolitan America. Rural Sociology, 48 (3), 458-470.

Cohen, S. S., \& Zysman, J. (1987) . Manufacturing matters. New York: Basic Books.

Curry, L. (1972). A spatial analysis of gravity flows. Regional studies, 6 (2), 131-147.

Davanzo, J. (1976). Why families move: A model of geographic mobility of married couples. Santa Monica, CA: Rand Corporation

Davanzo, J. (1978). Does unemployment affect migration? Evidence from micro data. Review of Economics and Statistics, 60 (4), 504-514.

Dejong, G. (1977). Residential preferences and migration. Demography, 14 (2), 169-178.

Dejong, G. F. (1980, November/December). Nonmetropolitan area migrants: Preference and satisfaction. Intercom, pp. 8-10.

Dejong, G. F. (1984). Migration decision-making. New York: Pergamon. 
Dejong, G. F., \& Sell, R. R. (1977, January). Population redistribution, migration, and residential preferences. Annals Amexican Academy of Social Sciences, $429,130-142$.

Dillman, D. A., \& Tremblay, K. R, , Jr. (1977, January) . The quality of life in rural America. Annals American Academy of Social Sciences, 429, 115-129.

Duncan, O. D. (1959). Human ecology and population studies. In P. Hauser \& O. D. Duncan (Eds.), The study of population (pp. 678-718). Chicago: University of Chicago Press.

Engels, R. A., \& Healy, M. K. (1981). Measuring interstate migration flows: An origin-destination network based on Internal Revenue Service records. Environmental Planning $A, 13$ (11), 1345-1360.

Erickson, R. (1976). The filtering process: Industrialization in a nonmetropolitan area. Professional Geographer, 28 (31), 254-260.

Fields, G. S. (1979, February). Place-to-place migration: Some evidence. Review of Economics and statistics, 61, 21-32.

Fotheringham, A. S. (1983). A new set of spatial interaction models: The theory of competing destinations. Environment and Planning $A, 15$ (1), 15-36.

Fotheringham, A. S., \& O'Kelly, M. E. (1989). Spatial interaction models: Formulations and applications. Dorbrescht, The Netherlands: Kluwer Academic Publishers.

Fotheringham, A. S., \& Webber, M. J. (1980). Spatial structure and distance decay. Geographical Analysis, 12 (1), 33-46.

Frey, W. H. (1979). The changing impact of white migration on the population compositions of origin and destination metropolitan areas. Demography, 16 (2), 218-237.

Frey, W. H. (1987). Migration and depopulation of the metropolis: Regional restructuring or rural renaissance? American Sociological Review, $\underline{52}$ (2), 240-257. 
Frey, w. H. (1988). The re-emergence of core region growth: A return to the metropolis? International Regional Science Review, 11 (3), 261-268.

Frey, w. (1989). United States: Counterurbanization and metropolis depopulation. In A. Champion (Ed.), Counterurbanization: The changing pace and nature of population deconcentration (pp. 34-61). London: Edward Arnold.

Friedman, J., \& Miller, J. (1965). The urban field. Journal of the American Institute of Planners, 31 (4), 312-319.

Frisbie, w. P. (1978). Sustenance organization and Population redistribution in nonmetropolitan America. Iowa City: University of Iowa Press.

Frisbie, W. P., \& Poston, D. L. (1975, December). Components of sustenance and organization and nonmetropolitan population change: A human ecological investigation. American Sociological Review, 40, 773-784.

Fuguitt, G. V. (1985). The nonmetropolitan population turnaround. Annual Review Sociology, 11 (Annual), 259-280.

Fuguitt, G. V., Voss, P. R., \& Doherty, J. C. (1979). Growth and change in rural America. Washington, DC: The Urban Land Institute.

Fuguitt, G. V., \& Zuiches, J. (1975). Residential preferences and population distribution. Demography, 12 (3), 491-504.

Garnick, D. (1984). Shifting balances in U.S. metropolitan and nonmetropolitan area growth. International Reqional Science Review, 9 (3), 257-273.

Gibbs, J. P., \& Martin, W. T. (1959). Toward a theoretical system of human ecology. Pacific Sociological Review, $\underline{2}(1), 29-36$.

Glasmeier, A. K. (1985). Innovative manufacturing industries: Spatial incidence in the United States. In M. Castells (Ed.), High technology, space and society (pp. 55-79). Beverly Hills: Sage Publications Urban Affairs Annual Reviews.

Gottdiener, M. (1985). The social production of urban space. Austin, TX: University of Texas Press. 
Graves, P. E. (1976) . A reexamination of migration, economic opportunity, and the quality of life. Journal of Regional Science, 16 (1), 107-112.

Graves, P. E. (1980). Migration and climate. Journal of Regional Science, 20 (2), 227-237.

Graves, P. E. (1983). Migration with a composite amenity: The role of rents. Journal of Regional Science, 23 (4), 541-546.

Graves, P. E., \& Knapp, T. (1988). Mobility behavior of the elderly. Journal of Urban Economics, 24 (1), 1-8.

Greenwood, M. (1973). Urban economic growth and migration: Their interaction. Environment and Planning, $\underline{5}$ (1), 91-112.

Greenwood, M. J. (1974) . A simultaneous-equations model of migration and economic change in rural areas: The case of the south. Review of Regional studies, 4 (3), $37-48$.

Greenwood, M. J. (1975) . Research on internal migration in United States: A survey. Journal of Economic Literature, 13 (2), 397-433.

Greenwood, M. J. (1981). Migration and economic growth in United States. New York: Academic Press.

Hansen, N. (1977). Some research and policy implications of recent migration patterns in industrial counties. International Regional Science Review, $\underline{2}$ (2), 161-166.

Hansen, N. (Ed.) - (1978) - Human settlement systems: International perspectives on structure, change and public policy. Cambridge: Ballinger Publishing.

Hawley, A. H. (1950). Human ecology. New York: Ronald Press.

Hawley, A. H. (1968). Ecology: Human ecology. In D. Sills (Ed.), International encyclopedia of the social sciences, Vol. 4 (pp. 328-332). New York: Crowell, Collier, and Macmillian.

Hawley, A. H. (1971). Urban society: An ecological approach. New York: The Ronald Press Company. 
Hawley, A. H. (1978). Spatial aspects of population: An overview. In K. E. Taeuber, L. L. Bumpass, \& J. A. Sweet (Eds.), Social demography (pp. 85-94). New York: Academic Press.

Hawley, A. H., \& Mazie, S. M. (Eds.). (1981). Nonmetropolitan America in transition. Chapel Hill: The University of North Carolina Press.

Haynes, K. E., \& Fotheringham, A. S. (1984) . Gravity and spatial interaction models. Beverly Hills: Sage Publications.

Heaton, T. B., Clifford, W. B., \& Fuguitt, G. (1981). Temporal shifts in the determinants of young and elderly migration in nonmetropolitan America. Social Forces, 60 (1), 41-60.

Heaton, T., Fredrickson, C., Fuguitt, G., \& Zuiches, J. (1979). Residential preferences, community satisfaction and the intention to move. Demography, 16 (4), 565-573.

Heaton, T., \& Fuguitt, G. (1979). Nonmetropolitan industrial growth and net migration. In R. E. Lonsdale \& H. L. Seyler (Eds.), Nonmetropolitan industrialization (pp. 119-136). New York: John Wiley and Sons.

Heilbrun, J. (1981). Urban economics and public policy. New York: st. Martin's Press.

Herzog, H. W., \& Bjornstad, D. J. (1982). Urbanization, interregional accessibility and the decision to migrate. Growth and Change, 13 (3), 21-25.

Hibbard, M. (1989). Issues and options for the other oregon. Community Development Journal, 24 (2), 145-153.

Hoch, I. (1972). Income and city size. Urban studies, 9 (3), 299-328.

Hoch, I. (1976, September). City size effects, trends, and policies. Science, 193, 856-863.

Humphrey, C. R., \& Sell, R. R. (1975). The impact of controlled access highways on population growth in Pennsylvania nonmetropolitan communities 1940-1970. Rural Sociology, 40 (3), 332-343. 
Isard, W. (1960). Methods of regional analysis. Cambridge, MA: MIT Press.

Isserman, A. M. (1977). The location quotient approach to estimating regional economic impacts. Journal of the American Institute of Planners, 43 (1), 33-41.

Isserman, A. M. (1985a) . Economic-demographic modelling with endogenously determined birth and migration rates: Theory and prospects. Environment and Planning A, 17 (1), 25-45.

Isserman, A. M. (Ed.). (1985b). Population change and the economy: Social science theories and models. Boston: Kluwer-Nijhoff Publishing.

Isserman, A. M., Plane, D. A., \& McMillen, D. B. (1982). Internal migration in the United states: An evaluation of federal data. Review of Public Data Use, 10 (4), 285-311.

Johansen, H. E., \& Fuguitt, G. V. (1984). The changing rural village in America: Demographic and economic trends since 1950. Cambridge: Ballinger Publishing Company.

Johnson, K. M. (1985). The impact of population change on business activity in rural America. Boulder, co: Westview Press.

Kale, S. R. (1989). Theories of nonmetropolitan economic change. Economic Development Quarterly, 3 (1), 58-69.

Kale, S. R. \& Lonsdale, R. E. (1979). Factors encouraging and discouraging plant location in nonmetropolitan areas. In R. E. Lonsdale \& H. L. Seyler (Eds.), Nonmetropolitan industrialization (pp. 47-56). New York: John wiley and Sons.

Karp, H. H. \& Kelly, K. D. (1971). Toward an ecological analysis of intermetropolitan migration. Chicago: Markham Publishing Company.

Kasarda, J. D. (1980). The implications of contemporary redistribution trends for national urban policy. Social science Quarterly, 61 $(3 / 4), 373-400$.

Kasarda, J. D. (1988). People and jobs on the move: America's new spatial dynamics. In G. Sternlieb \& J. W. Hughes (Eds.), America's new market geography (pp. 217-242). New Brunswick: Rutgers, The state University of New Jersey. 
Kirn, T. (1987). Growth and decline in the service sector of the U.S.: A spatial perspective. Annals of the Association of the American Geographers, 77 (3), 353-372.

Knapp, T. A., \& Graves, P. E. (1989). On the role of amenities in models of migration and regional development. Journal of Regional Science, 29 (1), 71-88.

Kuehn, J. A. (1979). Nonmetropolitan industrialization and migration: An overview with special emphasis on the ozarks region. In $R$. E. Lonsdale \& $H$. L. Seyler (Eds.), Nonmetropolitan industrialization (pp. 137-148). Washington, DC: V. H. Winston and Sons.

Labor Market and Economic Analysis Branch, washington state Employment Security Division. (1965). Washington labor market, employment, and payrolis in Washington state by county and industry. Olympia, WA: Author.

Labor Market and Economic Analysis Branch, Washington State Employment Security Division. (1970). Washington labor market, employment, and payrolis in Washington state by county and industry. Olympia, WA: Author.

Labor Market and Economic Analysis Branch, Washington state Employment Security Division. (1975). Washington labor market, employment, and payrolis in washington state by county and industry. Olympia, WA: Author.

Lansing, J., \& Mueller, E. (1967). The geographic mobility of labor. Ann Arbor: Survey Research Center.

Lee, E. (1966). A theory of migration. Demography, 3 (1), 45-57.

Lessinger, J. (1987, June). The emerging region of opportunity. American Demographics, 9 , 33-37.

Lichter, D. T., \& Fuguitt, G. (1982). The transition to nonmetropolitan population deconcentration.

Demography, 19 (2), 211-221.

Lichter, D., Fuguitt, G. V., \& Heaton, T. B. (1985). Components of nonmetropolitan population change: The contribution of rural areas. Rural Sociology, $\underline{50}$ (1), 88-98. 
Lichter, D., Heaton, T. B., \& Fuguitt, G. V. 1979. Trends in selectivity of migration between metropolitan and nonmetropolitan areas: 1955-1975. Rural Sociology, 44 (4), 645-667.

Liu, B. (1975a). Differential net migration rates and the quality of life. Review of Economics and statistics, 57 (3), 329-337.

Liu, B. (1975b) . Quality of life indicators in U.S. metropolitan areas 1970. New York: Praeger Publishers.

Liu, B. (1977). Economic and non-economic quality of life: Empirical indicators and policy implications for large standard metropolitan areas. The American Journal of Economics and Sociology, 36 (3), 225-240.

Long, L. H. , \& DeAre, D. (1980). Migration to nonmetropolitan areas: Appraising the trend and reasons for moving. Washington, DC: U.S. Bureau of Census Special Demographic Analysis.

Long, L., \& DeAre, D. (1983). The slowing of urbanization in the United States. Scientific American, 249 (1), $33-41$.

Lonsdale, R. E., \& Holmes, J. H. (1981). Settlement systems in sparsely populated regions in United states and Australia. New York: Pergamon Press.

Lonsdale, R. E., \& Seyler, H. L. (Eds.) . (1979). Nonmetropolitan industrialization. New York: V. H. Winston and Sons.

Lowry, I. S. (1966). Migration and metropolitan growth: Two analytical models. Los Angeles: University of California, Institute of Government and Public Affairs.

Malecki, E. J. (1984, Summer). High technology and local economic development. Journal of American Planning Association, 50, 262-269.

Markusen, A. (1984). profit cycles, oligopoly, and regional development. Cambridge: MIT Press.

Markusen, A. (1985). Steel and southeast Chicago: Reasons and opportunities for industrial renewal. Evanston, IL: Center for Urban Affairs and Policy Research. 
Markusen, A., Hall, P., \& Glasmeier, A. (1986). High tech America. Boston: Allen and Unwin.

Mazek, W. \& \& Chang, J. (1972). The chicken or egg fowl-up in migration: Comment. Southern Economic Journal, 39 (1), 133-139.

Mazek, W. F., \& Laird, W. E. (1974). City-size preferences and population distribution: The analytical context. Quarterly Review of Economics and Business, 14 91), 113-122.

McCarthy, K. F., \& Morrison, P. A. (1977). The changing demographic and economic structure of nonmetropolitan areas in the United States. International Regional Science Review, 2 (2), 123-142.

Menchik, M. D. (1981). The service sector. In A. Hawley \& S. M. Mazie (Eds.), Nonmetropolitan America in transition (pp. 231-254). Chapel Hill: University of North Carolina Press.

Miernyk, w. H. (1977). The changing structure of the southern economy. Research Triangle Park, NC: Southern Growth Policies Board.

Miller, A. (1967). The migration of employed persons to and from metropolitan areas of the United States. Journal of the American Statistical Association, 62 $(320), 1418-1432$.

Miller, A. R. (1966). Migration differentials in labor force participation: United states 1960. Demography, $\underline{3}(1), 58-67$.

Miller, E. (1973). Is out-migration affected by economic conditions? Southern Economic Journal, 39 (3), 396405 .

Miron, J. R. (1978). Job-search perspectives on migration behavior. Environment and Planning A, 10 (5), 519535.

Morrill, R. L. (1988a) . Intra metropolitan demographic structure: A Seattle example. Annuals Regional Science, 22 (1), 1-16.

Morrill, R. L. (1988b) - Migration regions and population. Growth Change, 19 (1), 43-60. 
Morrill, R. L., Downing, J., \& Leon, W. (1986). Attribute preferences and the nonmetropolitan migration decision. Annals of Regional Science, 20 (1), 33-53.

Morrison, P. (1975). Population movements and shape of urban growth: Implications for public policy. In $J$. Friedmann \& $W$. Alonso (Eds.), Reqional policy: Readings in theory and applications (pp. 221-243). Cambriage: MIT Press.

Mueser, P. R. (1987). Explaining the association between rates of in-migration and out-migration (CDE Working Paper 88-6). Madison: University of WisconsinMadison, Center for Demography and Ecology.

Mueser, P. M. , \& White, M. J. (1989). Explaining the association between rates of in-migration and out-migration. Papers of the Regional Science Association, Thirty-fifth North American Meeting, 67, $121-134$.

Murdock, S. H., Parpia, B., Hwang, S. \& Hamm, R. R. (1984). The relative effects of economic and noneconomic factors on age-specific migration, 1960-1980. Rural Sociology, 49 (2), 309-318.

Muth, R. F. (1971) . Migration: Chicken or egg? Southern Economic Journal, 37 (3), 295-306.

Muth, R. F. (1972). The chicken or egg fowl-up in migration: reply. Southern Journal of Economics, 39 (1), 139-141.

Myrdal, G. (1957). Economic theory and underdeveloped regions. London: G. Duckworth.

Norcliffe, G. (1984). Nonmetropolitan industrialization and the theory of production. Urban Geography, 5 (1), 25-42.

Norton, R. D. \& \& Rees, J. (1979). The product cycle and the spatial decentralization of American manufacturing. Regional studies, 13 (1), 141-151.

Noyelle, T. (1987). Beyond industrial dualism. Boulder, co: Westview Press.

Noyelle, T., \& Stanbach, T. M. (1984). The economic transformation of American cities. Totowa, NJ: Rowman and Allanheld. 
office of Technology Assessment. (1984). Technology, innovation and regional economic development. Washington, DC: Author.

Office of Technology Assessment. (1986). Technology and structural unemployment: Employing displaced adults. Washington, DC: Author.

Olvey, L. D. (1972). Regional growth and interregional migration--their pattern of interaction. Review of Regional studies, $\underline{2}$ (2), 139-163.

Oregon Employment Division. (1965, March). Oregon's labor force trends. Salem: Author.

Oregon Employment Division. (1970, March). Oregon's labor force trends. Salem: Author.

Oregon Employment Division. (1975, March). Oregon's labor force trends. Salem: Author.

Oregon Employment Division. (1980, March). oregon labor trends. Salem: Author.

Oregon State Highway Department. (1967). Oregon outdoor recreation. Salem: Author.

Oregon state Parks and Recreation. (1983). Oregon outdoor recreation, SCORP 183. Eugene: Author.

Park, S., \& Wheeler, J. (1983). The filtering down process in Georgia: The third stage after the product cycle. The Professional Geographer, 35 (1), 18-31.

Perloff, H., \& Wingo, L., Jr. (1961). Natural resource endowment and regional economic growth. In $J$. J. Spengler (Ed.), Natural resources and economic growth (pp. 191-212). Washington, DC: Resources for the Future.

Perry, D. C. \& Watkins, A. (1977). The rise of the sunbelt cities. Beverly Hills: Sage Publications.

Pindyck, R. S., \& Rubinfeld, D. L. (1981). Econometric and models: Economic forecasts. New York: McGraw Hill Book Company.

Plane, D. A., \& Isserman, A. M. (1983). U.S. interstate labor force migration: An analysis of trends, net exchanges, and migration subsystems. Socio-Economic Planning Sciences, $17(5 / 6), 251-266$. 
Poindexter, J. R., \& Clifford, W. R. (1983). Components of sustenance organization and nonmetropolitan change: The 1970's. Rural Sociology, 48 (3), 421-435.

Pol, L., Schafer, E., \& Sly, D. (1984). Disaggregating migration in ecological models, unpublished paper. Location: Florida State University.

Pred, A. R. (1973). Urban growth and the circulation of information: The United states system of cities 1790-1840. Cambridge: Harvard University Press.

Ravenstein, E. G. (1885, June). The laws of migration: Part 1. Journal of the Royal statistical Society, 48, 167-227.

Ravenstein, E. G. (1889, June). The laws of migration: Paper 2. Journal of the Royal statistical Society, 52, 241-301.

Rees, J. (1979). Technological change and regional shifts in American manufacturing. Professional Geographer, 31 (10), 45-54.

Renshaw, V. (1975). The relationship of gross migration to net migration: A short run, long run distinction. Regional Science Perspectives, $\underline{5}, 109-124$.

Richardson, H. W. (1972). Input-output and regional economics. New York: Wiley.

Richardson, H. W. (1973). Regional growth theory. New York: Wiley.

Richter, K. (1985). Nonmetropolitan growth in the late 1970's: The end of the turnaround? Demography, $\underline{22}$ (2), 245-262.

Roseman, C. C. (1983). Labor force migration, non-labor force migration, and nonemployment reasons for migration. Socio-Economic Planning Science, 17 (5-6), 303-312.

Sawers, L., \& Tabb, W. K. (1984). Sunbelt/snowbelt: Urban development and regional restructuring. New York: oxford Press. 
Saxenian, A. (1984). The urban contradictions of silicon valley: Regional growth and the restructuring of the semi-conductor industry. In L. Sawers \& W. Tabb (Eds.), Sunbelt/snowbelt: Urban development and regional restructuring (pp. 163-197). London: oxford University Press.

Saxenian, A. (1985). Silicon valley and route 128: Regional prototypes or historic exceptions? In $M$. Castells (Ed.), High technology, space and society (pp. 81-105). Beverly Hills: Sage Publications Urban Affairs Annual Reviews.

Scott, A. J. (1980). The urban nexus and the state. London, JK: Pion Limited.

Scott, A. J. (1988a). Meiropolis: From the division of labor to urban form. Berkeley: University of California Press.

Scott, A. J. (1988b) - New industrial spaces. London, UK: Pion Limited.

Scott, A. J., \& Storper, M. (Eds.). (1986). production work, territory: The geographical anatomy of industrial capitalism. Boston: Allen and Unwin.

Sen, A., \& Soot, S. (1981). Selected procedures for calibrating the generalized gravity model. Papers of Regional Science Association, Twenty-seventh North American Meeting, 48, 165-176.

Seyler, H. L. (1979). Dimensions of social and economic change: The impact of nonmetropolitan industrialization. In R. E. Lonsdale \& H. L. Seyler (Eds.), Nonmetropolitan industrialization (pp. 95-102). New York: John Wiley and Sons.

Shapira, P. , \& Leigh-Preston, N. (1984). Urban and rural development in the western United States--Emerging conflicts and planning issues. Journal of Architecture and Planning, 1 (1), 37-55.

Sharpless, J. (1980). Population redistribution in the American past: Empirical generalizations and theoretical perspectives. Social science ouarterly, $61(3,4), 401-417$.

Sheppard, E. (1978). Theoretical underpinnings of the gravity hypothesis. Geographical Analysis, 10, 386-402. 
Sheppard, E. (1979). Gravity parameter estimation. Geographic analysis, 11 (2), 120-132.

Sheppard, E. S., Griffith, D. A., \& Curry, L. (1976) . A final comment on misspecification and autocorrelation in those gravity parameters. Regional studies, 10 (3), 337-339.

Sjaastaad, L. A. (1962). The costs and returns of human migration. Journal of Political Economy, 70 (Suppl.), 80-93.

Sly, D. F. (1972, October). Migration and the ecological complex. American Sociological Review, 37, 615-628.

Sly, D. F., \& Tayman, J. (1977, October). Ecological approach to migration reexamined. American Sociological Review, 42, 783-795.

Sly, D. F., \& Tayman, J. (1980). Metropolitan morphology and population mobility: The theory of ecological expansion reexamined. American Journal of Sociology, $\underline{86}$ (1), 119-138.

Smith, T. R. (1979). Migration, risk aversion, and regional differentiation. Journal of Regional Science, 19 (1), 31-45.

Sofranko, A. J., \& Williams, J. D. (1980). Rebirth of rural America: Rural migration in the midwest. Ames: Iowa State University, North Central Regional Center for Rural Development.

Stanbach, T. M., \& Noyelle, T. (1982). Cities in transition. Totowa, NJ: Allanheld, Osman Company.

Stevens, J. B. (1980). The demands for public goods as a factor in the nonmetropolitan migration turnaround. In J. M. Wardwell \& D. L. Brown (Eds.), New directions in urban-rural migration: The population turnaround in rural America (pp. 115-135). New York: Academic Press.

Stone, L. O. (1971). On the correlation between metropolitan in-migration and out-migration by occupation. Journal of the American Statistical Association, 66 (336), 693-701. 
Storper, M. \& \& Walker, R. (1984). Spatial division of labor: Labor and the location of industries. In L. Sawers \& W. Tabb (Eds.), Sunbelt/snowbelt: Urban development and regional restructuring (pp. 19-47). London: Oxford University Press.

Summers, G. F. (Ed.). (1984). Deindustrialization: Restructuring the economy. Annals of the Academy of Political and Social Science. Beverly Hills: Sage Publications.

Svart, L. M. (1976). Environmental preferences, migration: A review. Geographical Review, 66 (3), 314-330.

Taeuber, K., Bumpass, L., \& Sweet, J. (1978). Social demography. New York: Academic Press.

Thompson, W. R. (1972). A preface to urban economics. Baltimore: Resources for the Future.

Thompson, W. R. (1973). The economic base of urban problems. In N. W. Chamberlain (Ed.), Contemporary economic issues (pp. 1-49). Homewood, IL: Richard D. Irwin, Inc.

Thompson, W. R. (1975a). Economic processes and employment problems in declining metropolitan areas. In $\mathbf{G}$. Sternlieb \& J. W. Hughes (Eds.), Post-industrial America: Metropolitan decline and inter-regional job shifts (pp. 187-196). New Brunswick, NJ: The Center for Urban Policy Research.

Thompson, W. R. (1975b). Internal and external factors in development of urban economics. In J. Friedmann \& W. Alonso (Eds.), Regional policy: Readings in theory and applications (pp. 201-220). Cambridge: MIT Press.

Thompson, W. R. (1975c). The national system of cities as an object of public policy. In J. Friedmann \& W. Alonso (Eds.), Regional policy: Readings in theory and applications (pp. 516-533). Cambridge: MIT Press.

Till, T. E. (1981). Manufacturing industry: Trends and impacts. In A. Hawley \& S. M. Mazie (Eds.), Nonmetropolitan America in transition (pp. 194-230). Chapel Hill: The University of North Carolina Press.

Tucker, C. J. (1976). Changing patterns of migration between metropolitan and nonmetropolitan areas in United States: Recent evidence. Demography, 13 (4), 435-443. 
U.S. Department of Commerce, Bureau of Census. (1960). U.S. Census of population and housing: Population characteristics. Washington, DC: U.S. Government Printing office.

U.S. Department of Commerce, Bureau of Census. (1962a). census of governments, government finances, compendium of government finances. Washington, DC: U.S. Government Printing office.

U.S. Department of Commerce, Bureau of Census. (1962b). Census of governments, public employment, compendium of public employment. Washington, DC: U.S. Government Printing office.

U.S. Department of Commerce, Bureau of Census. (1962c). county and city data book. Washington, DC: U.S. Government Printing Office.

U.S. Department of Commerce, Bureau of Census. (1965). county business patterns. Washington, DC: U.S. Government Printing office.

U.S. Department of Commerce, Bureau of Census. (1966). Reasons for moving, March 1963. Current Population Reports P-20 (No. 154). Washington, DC: U.S. Government Printing office.

U.S. Department of Commerce, Bureau of Census. (1967a). Census of governments, government finances, compendium of government finances. Washington, DC: U.S. Government Printing office.

U.S. Department of Commerce, Bureau of Census. (1967b). Census of governments, public employment, compendium of public employment. Washington, DC: U.S. Government Printing office.

U.S. Department of Commerce, Bureau of Census. (1967c). county and city data book. Washington, DC: U.S. Government Printing Office.

U.S. Department of Commerce, Bureau of Census. (1970a). U.S. census of population and housing: Population characteristics. Washington, DC: U.S. Government Printing office.

U.S. Department of Commerce, Bureau of Census. (1970b). County business patterns. Washington, DC: U.S. Government Printing office. 
U.S. Department of Commerce, Bureau of Census. (1972a). census of governments, government finances, compendium of government finances. Washington, DC: U.S. Government Printing office.

U.S. Department of Commerce, Bureau of Census. (1972b) . Census of governments, public employment, compendium of public employment. Washington, DC: U.S. Government Printing office.

U.S. Department of Commerce, Bureau of Census. (1972C) . County and city data book. Washington, DC: U.S. Government Printing Office.

U.S. Department of Commerce, Bureau of Census. (1975). County business patterns. Washington, DC: U.S. Government Printing Office.

U.S. Department of Commerce, Bureau of Census. (1977a). Census of governments, government finances, compendium of government finances. Washington, DC: U.S. Government Printing office.

U.S. Department of Commerce, Bureau of Census. (1977b) . Census of governments, public employment, compendium of public employment. Washington, DC: U.S. Government Printing office.

U.S. Department of Commerce, Bureau of Census. (1977c). county and city data book. Washington, DC: U.S. Government Printing office.

U.S. Department of Commerce, Bureau of Census. (1980a) . U.S. census of population and housing: Population characteristics. Washington, DC: U.S. Government Printing office.

U.S. Department of Commerce, Bureau of Census. (1980b). county business patterns. Washington, DC: U.S. Government Printing office.

U.S. Department of Commerce, Bureau of Census. (1981). Geographic mobility: March 1975 to March 1980. Current population Reports Series P-20 (No. 368). Washington, DC: Government Printing office.

U.S. Department of Commerce, Bureau of Economic Analysis. (1976a). Continuous work history one percent sample [Machine-readable tape]. Washington, DC: U.S. Government Printing office. 
U.S. Department of Commerce, Bureau of Economic Analysis. (1976b). Regional work force characteristics and migration data. Washington, DC: U.S. Government Printing office.

U.S. Department of Education, National Center for Education Statistics. (1965). Fall enrollment in colleges and universities. Washington, DC: Author.

U.S. Department of Education, National Center for Education Statistics. (1970). Fall enrollment in colleges and universities. Washington, DC: Author.

U.S. Department of Education, National Center for Education statistics. (1975). Fall enrollment in colleges and universities. Washington, DC: Author.

U.S. Department of Justice, Federal Bureau of Investigations. (1965). Uniform crime reports for the United States. Washington, DC: U.S. Government Printing office.

U.S. Department of Justice, Federal Bureau of Investigations. (1970). Uniform crime reports for the United States. Washington, DC: U.S. Government Printing office.

U.S. Department of Justice, Federal Bureau of Investigations. (1975). Uniform crime reports for the United States. Washington, DC: U.S. Government Printing office.

U.S. Energy Information Administration. (1965). Typical monthly electric bills--Residential and commercial. Washington, DC: U.S. Government Printing office.

U.S. Energy Information Administration. (1970). Typical monthly electric bills--Residential and commercial. Washington, DC: U.S. Government Printing Office.

U.S. Energy Information Administration. (1975). Typical monthly electric bills--Residential and commercial. Washington, DC: U.S. Government Printing Office.

U.S. National Center for Education Statistics. (1965). Education directory, public school systems. Washington, DC: U.S. Government Printing Office.

U.S. National Center for Education Statistics. (1970) . Education directory, public school systems. Washington, DC: U.S. Government Printing Office. 
U.S. National Center for Education Statistics. (1975) . Education directory, public school systems. Washington, DC: U.S. Government Printing Office.

U.S. National Center for Health Statistics. (1960). Vital statistics of the United States, Vol. I Natality and Vol. II Mortality. Washington, DC: U.S. Government Printing office.

U.S. National Center for Health Statistics. (1965). Vital statistics of the United States, Vol. I Natality and Vol. II Mortality. Washington, DC: U.S. Government Printing office.

U.S. National Center for Health statistics. (1970) Vital statistics of the United States, Vol. I Natality and Vol. II Mortality. Washington, DC: U.S. Government Printing office.

U.S. National Center for Health Statistics. (1975) Vital statistics of the United States, Vol. I Natality and Vol. II Mortality. Washington, DC: U.S. Government Printing office.

Vernon, R. (1966). International investment and international trade in the product cycle. Quarterly Journal of Economics, 80 (2), 190-207.

Vining, D. R., \& strauss, A. (1977). A demonstration that the current deconcentration in the United states is a clean break with the past. Environment and Planning A, $\underline{9}$ (7), 751-758.

Vining, D. R., Jr., \& Kontuly, T. P. (1978). Population dispersal from metropolitan regions: An international comparison. International Regional Science Review, $\underline{\mathbf{2}}$ (1), 49-73.

Vining, D. R., Jr., \& Pallone, R. (1982). Migration between core and peripheral regions: A description and tentative explanation of the patterns in 22 countries. Geoforum, 13 (4), 339-410.

Wardwell, J. M. (1977). Equilibrium and change in nonmetropolitan growth. Rural Sociology, 42 (2), 156-179.

Wardwell, J.M. (1980). Toward a theory of urban-rural migration in the developed world. In J. M. Wardwell \& D. L. Brown (Eds.), New directions in urban-rural migration: The population turnaround in rural America (pp. 71-114). New York: Academic Press. 
Wardwell, J. M., \& Brown, D. L. (1980). Population redistribution in the United staces during the 1970's. In J. M. Wardwell \& D. L. Brown (Eds.), New directions in urban-rural migration: The population turnaround in rural America (pp. 5-35). New York: Academic Press.

Wardwell, J. M., \& Gilchrist, C. J. (1980). Employment deconcentration in the nonmetropolitan migration turnaround. Demography, 17 (2), 145-156.

Washington State Data Centers. (1965). Population estimates. Olympia, WA: Author.

Washington State Data Centers. (1975). Population estimates. Olympia, WA: Author.

Washington State Motor Vehicle Department. (1975). pleasure boat usage handout. Olympia, WA: Author.

Washington State Interagency Committee for outdoor Recreation. (1983). Washington's statewide comprehensive outdoor recreation plan. Olympia: Washington State Parks and Recreation Commission.

Washington State Office of Financial Management. (1983) . Washington state data book. Olympia, WA: Estimation and Forecasting Unit.

Weinstein, B. L., Gross, H. T. \& Rees, J. (1985). Regional growth and decline in the United states. New York: Praeger Special studies.

Wheaton, w. C. (1979). Metropolitan growth, unemployment, and interregional factor mobility. In $W$. Wheaton (Ed.), Interregional movements and regional growth (pp. 237-253). Washington, DC: The Urban Institute.

Williams, J. D. (1981a). Migration decision making among nonmetropolitan-bound migrants. In J. M. Wardwell \& D. L. Brown (Eds.), New directions in urban-rural migration: The population turnaround in rural America (pp. 189-211). New York: Academic Press.

Williams, J. D. (1981b). The nonchanging determinants of nonmetropolitan migration. Rural sociology, 46 (2), 183-202.

Williams, J. D., \& MCMillen, D. B. (1983) . Locationspecific capital and destination selection among migrants to nonmetropolitan areas. Rural Sociology, 48 (3), 447-457. 
Williams, J. D., \& Sofranko, A. (1979). Motivations for the inmigration component of the population turnaround in nonmetropolitan areas. Demography, 16 (2), 239255.

wilson, F. D. (1978). The organizational components of expanding metropolitan systems. In $\mathrm{K}$. E. Taeuber, L. L. Bumpass, \& J. A. Sweet (Eds.), Social demography (pp. 133-156). New York: Academic Press.

Zelinsky, w. (1971). The hypothesis of the mobility transition. Geographical Review, 61 (2), 219-249.

Zelinsky, w. (1977). Coping with the migration turnaround: The theoretical challenge. International Regional Science Review, $\underline{2}$ (2), 175-178.

Zelinsky, w. (1978). Is nonmetropolitan America being repopulated? The evidence from Pennsylvania's minor civil divisions. Demography, 15 (1), 13-39.

Zuiches, J. J. (1980). Residential preferences in migration theory. In D. Brown \& J. Wardwell (Eds.), New directions in urban and rural migration: The population turnaround in United states (pp. 163-188). New York: Academic Press.

Zuiches, J. J. (1981). Residential preferences in the United states. In A. H. Hawley \& S. M. Mazie (Eds.), Nonmetropolitan America in transition (pp. 72-115). Chapel Hill: The University of North Carolina Press.

Zuiches, J., \& Brown, D. (1978). The changing character of the nonmetropolitan population 1970-1975. In T. R. Ford (Ed.), Rural USA: Persistence and change (ch. 4). Iowa: Iowa State University Press.

Zuiches, J. J., \& Price, M. L. (1980). Industrial dispersal and labor-force migration: population turnaround in Michigan. In D. Brown \& J. Wardwell (Eds.), New directions in urban-rural migration: The population turnaround in rural America (pp. 333-359). New York: Academic Press. 
APPENDIX A

THE MODELS USED TO CALCULATE THE LABOR POTENTIAL INDEX 
MODEL A1

MODEL RESULTS FOR CALIBRATING NONLINEAR ESTIMATES OF LAABOR POTENTIAL MODEL

$\log f \operatorname{low}=B_{0}+B_{1} * \log$ (population at origin) $+B_{2} * \log$ (population at destination) $+B_{3} * \log ($ dij $)+$ error

\begin{tabular}{|c|c|c|c|c|c|c|}
\hline & BO & $\underset{B 1}{\operatorname{Expl}}$ & ${ }_{B 2}$ & $B 3$ & Sums & Sums \\
\hline \multicolumn{7}{|c|}{1965 Origin Model } \\
\hline $\begin{array}{l}\text { Nonadjacent } \\
\text { Adjacent } \\
\text { Small Metro } \\
\text { Large Metro }\end{array}$ & $\begin{array}{l}4.14 \\
3.75 \\
3.52 \\
3.52\end{array}$ & $\begin{array}{l}-0.978 \\
-0.9504 \\
-0.9210 \\
-0.744\end{array}$ & $\begin{array}{l}-0.031 \\
-0.038 \\
-0.113 \\
-0.223\end{array}$ & $\begin{array}{l}-0.131 \\
-0.164 \\
-0.331 \\
-0.496\end{array}$ & $\begin{array}{l}269303 \\
224414 \\
146228 \\
199517\end{array}$ & $\begin{array}{r}452 \\
406 \\
475 \\
1110\end{array}$ \\
\hline \multicolumn{7}{|c|}{1970 origin Model } \\
\hline $\begin{array}{l}\text { Nonadjacent } \\
\text { Adjacent } \\
\text { Small Metro } \\
\text { Large Metro }\end{array}$ & $\begin{array}{l}4.000 \\
3.870 \\
3.341 \\
1.113\end{array}$ & $\begin{array}{l}-0.972 \\
-0.942 \\
-0.915 \\
-0.765\end{array}$ & $\begin{array}{l}0.040 \\
0.050 \\
0.149 \\
0.265\end{array}$ & $\begin{array}{r}-0.132 \\
-0.164 \\
-0.332 \\
0.496\end{array}$ & $\begin{array}{l}268855 \\
222943 \\
145029 \\
198508\end{array}$ & $\begin{array}{r}478 \\
515 \\
549 \\
1183\end{array}$ \\
\hline \multicolumn{7}{|c|}{1975 Origin Model } \\
\hline $\begin{array}{l}\text { Nonadjacent } \\
\text { Adjacent } \\
\text { Small Metro } \\
\text { Large Metro }\end{array}$ & $\begin{array}{l}4.060 \\
3.750 \\
3.550 \\
1.000\end{array}$ & $\begin{array}{l}-0.973 \\
-0.948 \\
-0.912 \\
-0.729\end{array}$ & $\begin{array}{r}0.027 \\
0.036 \\
0.135 \\
-0.504\end{array}$ & $\begin{array}{l}-0.132 \\
-0.165 \\
-0.332 \\
-0.496\end{array}$ & $\begin{array}{l}269893 \\
224397 \\
144886 \\
196031\end{array}$ & $\begin{array}{r}394 \\
388 \\
547 \\
1264\end{array}$ \\
\hline \multicolumn{7}{|c|}{1965 Destination Model } \\
\hline $\begin{array}{l}\text { Nonadjacent } \\
\text { Adjacent } \\
\text { Small Metro } \\
\text { Large Metro }\end{array}$ & $\begin{array}{l}4.141 \\
3.750 \\
3.520 \\
1.290\end{array}$ & $\begin{array}{l}0.022 \\
0.049 \\
0.078 \\
0.255\end{array}$ & $\begin{array}{l}-0.969 \\
-0.961 \\
-0.886 \\
-0.776\end{array}$ & $\begin{array}{l}-0.116 \\
-0.139 \\
-0.350 \\
-0.568\end{array}$ & $\begin{array}{l}363968 \\
264925 \\
104509 \\
106289\end{array}$ & $\begin{array}{r}452 \\
406 \\
475 \\
1110\end{array}$ \\
\hline \multicolumn{7}{|c|}{1970 Destination Model } \\
\hline $\begin{array}{l}\text { Nonadjacent } \\
\text { Adjacent } \\
\text { Smail Metro } \\
\text { Large Metro }\end{array}$ & $\begin{array}{l}4.033 \\
3.740 \\
3.520 \\
1.233\end{array}$ & $\begin{array}{l}0.030 \\
0.048 \\
0.126 \\
0.261\end{array}$ & $\begin{array}{l}-0.973 \\
-0.950 \\
-0.901 \\
-0.736\end{array}$ & $\begin{array}{l}-0.116 \\
-0.139 \\
-0.350 \\
-0.568\end{array}$ & $\begin{array}{l}269404 \\
262460 \\
145764 \\
195833\end{array}$ & $\begin{array}{r}427 \\
457 \\
525 \\
1199\end{array}$ \\
\hline \multicolumn{7}{|c|}{1975 Destination Model } \\
\hline $\begin{array}{l}\text { Nonadjacent } \\
\text { Adjacent } \\
\text { Small Metro } \\
\text { Large Metro }\end{array}$ & $\begin{array}{l}4.007 \\
3.590 \\
3.290 \\
1.255\end{array}$ & $\begin{array}{l}0.036 \\
0.052 \\
0.155 \\
0.284\end{array}$ & $\begin{array}{l}-0.969 \\
-0.940 \\
-0.916 \\
-0.791\end{array}$ & $\begin{array}{r}-0.115 \\
-0.139 \\
-0.350 \\
0.568\end{array}$ & $\begin{array}{l}268967 \\
223247 \\
144795 \\
198453\end{array}$ & $\begin{array}{r}450 \\
507 \\
562 \\
1241\end{array}$ \\
\hline
\end{tabular}


APPENDIX B

A COMPARISON OF THE CONTROLLED AND UNCONTROLLED ADJACENT MODELS 
COMPARISON B1

A COMPARISON OF ADJACENT LABOR MIGRATION MODELS

\begin{tabular}{|c|c|c|c|c|}
\hline & \multicolumn{2}{|c|}{$\begin{array}{c}\text { ADJACENT OUT-MIGRATION } \\
\text { MODEL }\end{array}$} & \multicolumn{2}{|c|}{$\begin{array}{c}\text { ADJACENT IN-MIGRATION } \\
\text { MODEL }\end{array}$} \\
\hline VARIABLE & $\begin{array}{l}\text { NRESTRICTED } \\
\text { MODEL }\end{array}$ & $\begin{array}{l}\text { RESTRICTED } \\
\text { MODEL }\end{array}$ & $\begin{array}{l}\text { UNRESTRICTED } \\
\text { MODEL }\end{array}$ & $\begin{array}{l}\text { RESTRICTE } \\
\text { MODEL }\end{array}$ \\
\hline $\begin{array}{l}\text { ECONOMIC ACTII } \\
\text { BASIC } \\
\text { NONBASIC }\end{array}$ & $\begin{array}{l}\text { VITIES } \\
-2.064 \\
0.216\end{array}$ & $\begin{array}{l}-1.937 \\
-2.001\end{array}$ & $\begin{array}{l}0.762 \\
1.306\end{array}$ & $\begin{array}{l}-1.937 \\
-2.001\end{array}$ \\
\hline \multicolumn{5}{|c|}{ ENVIRONMENTAL AMENITIES } \\
\hline COLLEGE & 1.903 & 2.888 & 0.723 & 2.880 \\
\hline EXPENDITURES & -0.728 & -0.617 & -0.134 & -0.062 \\
\hline RECREATION & -1.837 & -1.678 & 1.408 & -1.678 \\
\hline INCOME & 0.614 & 0.412 & 1.297 & 0.412 \\
\hline \multicolumn{5}{|c|}{ ENVIRONMENTAL DISAMENITIES } \\
\hline $\begin{array}{l}\text { AGE DEPENDENCY } \\
\text { UNEMPLOYMENT } \\
\text { NONWHITE } \\
\text { CRIME } \\
\text { CLIMATE } \\
\text { HOUSING }\end{array}$ & $\begin{array}{r}Y 0.264 \\
-0.252 \\
0.233 \\
6.446 \\
-1.229 \\
-1.613\end{array}$ & $\begin{array}{r}0.862 \\
-0.846 \\
1.042 \\
6.984 \\
-0.400 \\
-2.256\end{array}$ & $\begin{array}{r}-2.606 \\
-0.888 \\
0.873 \\
0.549 \\
1.699 \\
-1.359\end{array}$ & $\begin{array}{r}0.862 \\
-0.846 \\
1.042 \\
6.984 \\
-0.400 \\
-2.256\end{array}$ \\
\hline \multicolumn{5}{|l|}{ ACCESSIBILITY } \\
\hline $\begin{array}{l}\text { GRAVITY } \\
\text { CONTIGUOUS }\end{array}$ & $\begin{array}{l}3.157 \\
1.109\end{array}$ & $\begin{array}{r}18.747 \\
1.608\end{array}$ & $\begin{array}{l}10.231 \\
-1.056\end{array}$ & $\begin{array}{r}18.747 \\
1.608\end{array}$ \\
\hline POPULATION & -16.434 & -76.236 & -49.796 & -76.236 \\
\hline
\end{tabular}


COMPARISON B2

\section{A COMPARISON OF ADJACENT BASIC EMPLOYMENT MODELS}

\begin{tabular}{lrrrr} 
BASIC EMPLOYMENT & & & & \\
\hline OUT-MIGRANTS & 2.695 & 6.801 & -5.273 & 6.801 \\
NONBASIC & -77.473 & -15.122 & 19.537 & -15.122 \\
ROUTINE MFG & -8.596 & -9.864 & -6.034 & -9.864 \\
AGRICULTURE & -6.399 & -5.164 & -5.160 & -5.164 \\
PRODUCER & 0.215 & 0.228 & 6.155 & 0.228 \\
ENERGY & 2.458 & 0.966 & 10.196 & 0.966 \\
WAGES & 3.332 & -0.487 & -0.950 & -0.487 \\
FREEWAY & -0.685 & -3.679 & 9.083 & -3.679 \\
- & &
\end{tabular}

COMPARISON B3

A COMPARISON OF ADJACENT NONBASIC EMPLOYMENT MODELS

\begin{tabular}{lrrrr} 
OUT-MIGRANTS & -1.339 & -22.063 & 2.047 & -28.102 \\
BASIC & -84.339 & -63.831 & 16.769 & -58.311 \\
PERSONAL SERVICE & 14.529 & -10.813 & 8.068 & -4.312 \\
RETAIL & -16.731 & 4.296 & -25.598 & -2.518 \\
GOVERNMENT & -4.691 & -9.329 & -11.799 & -12.625 \\
WAGES & -3.144 & 9.624 & -7.302 & -5.493 \\
RETIREMENT & -0.039 & 14.261 & 10.081 & 11.528 \\
\hline
\end{tabular}


APPENDIX C

F TESTS OF MODELS 


\section{METHODOLOGY USED FOR F TEST FOR} TEMPORAL COMPARISONS

To test whether the coefficients of the three different periods are equal, an $F$ test is performed that compares whether the restricted sum of squares of the errors are equal to the unrestricted sum of squares of the errors. The restricted model is the combined model for all periods. This formula is frequently used to test equality of coefficients of different regressions (Pindyck \& Rubinfeld, 1981, pp. 123-125).

The hypothesis test for the combined model is:

$$
\mathrm{H}_{\mathrm{o}}: \beta_{\mathrm{i}}=\gamma_{\mathrm{i}}=\theta_{\mathrm{i}} \text {. }
$$

This test assumes if the null hypothesis is true, the regression results for the different periods are assumed to be equal. To perform the test of equality, it is assumed that the coefficients of the turnaround model would be equal to the coefficients of the two pre-turnaround models. Therefore, for this study, the turnaround period coefficients are used to impose the coefficient restrictions on the combined model (Pindyck \& Rubinfeld, 1981, p. 125).

$$
\underline{F}=\frac{\left(E S S_{R}-E S S_{U R}\right) / k}{E S S_{U R} /(N-3 k)}
$$

where ESS $_{\mathbf{R}}=$ Error of restricted (the combined models ${ }^{1}$

$$
\begin{aligned}
\text { ESS }_{\mathrm{UR}}= & \text { Error of unrestricted models } \\
\mathrm{N}= & \text { number of cases } \\
\mathrm{k}= & 16 \text { (the } 15 \text { coefficients in the labor } \\
& \text { model plus the intercept coefficient). }
\end{aligned}
$$

'The restricted error is the sum of errors for all three temporal models combined, which are the data files for labor migration flows for the periods 1960-1965, 1965-1970 (the two pre-turnaround periods), and 1970-1975 (the turnaround period).

${ }^{2}$ The unrestricted model is the sum of the errors for the three unrestricted models, in other words $\mathrm{ESS}_{\mathrm{UR}}=\mathrm{ESS}_{1960-1965}+\mathrm{ESS}_{1965-1970}+$ ESS $_{1970-1975} \cdot$ 
TEST C1

COMPARING THE DESTINATION TURNAROUND MODEL WITH THE PRE-TURNAROUND MODELS

$\begin{aligned} & \text { Spatial } \\
& \text { Region } \\
& \text { K=16 }\end{aligned}$
\begin{tabular}{|l|l|l|l|l|l||}
\hline Error & Errosicted Unrestricted \\
Nonadjacent & 11056 & 8217 & $488+6103+1626$ & 22167 & 479.5 \\
\hline Adjacent & 3128 & 3078 & $620+1204+1254$ & 16221 & 16.44 \\
\hline Small Metro & 9905 & 5086 & $1171+2256+1659$ & 6717 & 396.2 \\
\hline Large Metro & 26336 & 8261 & $8261+6045+1596$ & 7437 & 304.7 \\
\hline
\end{tabular}

\section{TEST C2}

THE ORIGIN TURNAROUND MODEL WITH THE PRE-TURNAROUND MODELS

Spatial Restricted Unrestricted

$\begin{array}{llll}\text { Region Error Error } \mathrm{ESS}_{1}+\mathrm{ESS}_{2}+\mathrm{ESS}_{3} * \mathrm{~N} & \mathrm{~F}\end{array}$

\begin{tabular}{||l|l|l|l|l|l||}
\hline Nonadjacent & 4927 & 2476 & $1427+628+421$ & 22167 & 1291.7 \\
\hline Adjacent & 3617 & 3090 & $485+1822+783$ & 16221 & 172.62 \\
\hline Small Metro & 3896 & 3674 & $1394+723+1536$ & 1536 & 404.37 \\
\hline Large Metro & 12685 & 5798 & $1097+1982+2719$ & 7437 & 404.37 \\
\hline
\end{tabular}

$\star \mathrm{ESS}_{1}+\mathrm{ESS}_{2}+\mathrm{ESS}_{3}=$ The sum of squares of the errors for the 1960-1965 model + the sum of squares of the errors for the 1965-1970 model + the sum of squares of the errors for the 1970-1975 model. 
METHODOLOGY USED FOR F TESTS USED

TO COMPARE SPATIAL REGIONS

$$
\begin{gathered}
\mathrm{F}=\frac{\left(E S S_{\mathrm{R}}-\mathrm{ESS}_{\mathrm{UR}}\right) / \mathrm{k}}{\mathrm{ESS}_{\mathrm{UR}} /(\mathrm{N}+\mathrm{M}-2 \mathrm{k})} \\
\text { where } \mathrm{ESS}_{\mathrm{R}}=\text { Error of restricted model }{ }^{1} \\
\mathrm{ESS}_{\mathrm{UR}}=\text { Error of unrestricted model }{ }^{2} \\
\mathrm{~N}=\text { number of cases of region }{ }_{1} \\
\mathrm{M}=\text { number of cases of region }
\end{gathered}
$$

${ }^{1}$ The restricted models are calibrated from the combined data files, i.e. nonmetropolitan = nonadjacent + adjacent and metropolitan $=$ small metro + large metro counties.

${ }^{2}$ The unrestricted model's sum of errors for nonmetropolitan = ESS noudjacent and ESS wjacent and metropolitan = ESS amall metropolitun and ESS targe metropoliten * 
TEST C3

THE NONMETROPOLITAN AND METROPOLITAN DESTINATION MODEL COMPARISONS

\begin{tabular}{|c|c|c|c|c|}
\hline $\begin{array}{l}\text { Spatial } \\
\text { Region } \\
\mathrm{K}=16\end{array}$ & $\begin{array}{c}\text { Restricted } \\
\text { Error }\end{array}$ & $\begin{array}{l}\text { Unrestricted* } \\
\text { Error }\end{array}$ & $\mathrm{N}+\mathrm{M}$ & F \\
\hline Nonmetro & 3842 & 2880 & 12796 & 266.51 \\
\hline $\begin{array}{l}\text { (Nonadjacent }+ \\
\text { Adjacent) }\end{array}$ & & & & \\
\hline Metro & 4476 & 3255 & 4718 & 110.59 \\
\hline $\begin{array}{l}\text { (Small Metro }+ \\
\text { Large Metro) }\end{array}$ & & & & \\
\hline
\end{tabular}

TEST C4

THE NONMETROPOLITAN AND METROPOLITAN ORIGIN MODEL COMPARISONS

$\begin{aligned} & \text { Spatial } \\
& \text { Region } \\
& \text { K=16 }\end{aligned}$
\begin{tabular}{|l|l|l|l|l||}
\hline $\begin{array}{l}\text { Error } \\
\text { Nonmetro }\end{array}$ & 1720 & 1204 & 12796 & 358.33 \\
\hline $\begin{array}{l}\text { * Nonadjacent }+ \\
\text { Adjacent) }\end{array}$ & & & & \\
\hline Metro & 4722 & 4275 & 4718 & 30.633 \\
\hline $\begin{array}{l}\text { * (Small Metro }+ \\
\text { Large Metro) }\end{array}$ & & & & \\
* The Combined models (the restricted model) &
\end{tabular}

Note Unrestricted Error varies according to:

1) Nonmetropolitan = the sum of squares of the errors for the nonadjacent + the adjacent nonmetropolitan models.

2) Nonmetropolitan $=$ the sum of squares of the errors for the nonadjacent + the adjacent nonmetropolitan models. 
F TEST FOR COMPARISON OF LABOR IN-MIGRATION AND LABOR OUT-MIGRATION MODELS

\author{
$\underline{F}=\quad\left(E S S_{R}-E S S_{U R}\right) / k$ \\ $\mathrm{ESS}_{\mathrm{UR}} /(\mathrm{N}-2 \mathrm{k})$ \\ where \\ ESS $_{\mathbf{R}}=$ Error of restricted mode ${ }^{1}$
$\mathrm{ESS}_{\mathrm{UR}}=$ Error of unrestricted model ${ }^{2}$
$\mathrm{N}=$ number of cases
$\mathrm{k}=16$

'To test whether the parameters are equal for the 1975 labor in-migration and labor out-migration models, the parameter coefficients $\left(B_{i}\right)$ in the labor in-migration model have been set equal to the parameter coefficients in the labor out-migration model and vice versa. The resulting error of the sums of square of the restricted model is then compared to the unrestricted labor in-migration model to test whether the difference is statistically significant or not. If the difference is statistically significant, then one cannot say that the beta coefficients of the restricted and unrestricted models are equal. In other words, one cannot say that the beta coefficients in the labor in-migration model and the labor out-migration model are equal.

${ }^{1}$ Restricted model is combined models for labor in-migration and labor out-migration for the turnaround period (1970-1975).

\footnotetext{
${ }^{2}$ The unrestricted model sum of squares $\left(\mathrm{ESS}_{\mathrm{UR}}\right)=\mathrm{ESS}_{\mathrm{In} \cdot \text { Migntion }}$ Model + ESS $_{\text {Out-Migration Model }}$.
} 
TEST C5

LABOR MIGRATION MODEL TESTS

$\begin{aligned} & \text { Spatial } \\
& \text { Region } \\
& \text { K=16 }\end{aligned}$
\begin{tabular}{|l|l|l|l|l|}
\hline Nonadjacent & 3405 & 2047 & 14778 & Fricted \\
\hline Nonarestricted* & $\begin{array}{l}\text { Urires } \\
\text { Error }\end{array}$ & 612.82 \\
\hline Adjacent & 5499 & 2037 & 5375 & 1145.44 \\
\hline Small Metro & 3516 & 3215 & 4478 & 26.02 \\
\hline Large Metro & 10586 & 4315 & 4958 & 447.928 \\
\hline
\end{tabular}

*Restricted Model= Combined Labor In-migration + Labor Out-Migration Model (Testing Ho: $\mathrm{H}_{\mathrm{o}}: \beta_{\mathrm{i}}=\gamma_{\mathrm{i}}$ ).

Unrestricted $=$ The sum of squares of error for labor in-migration model + the sum of squares of error for labor out-migration model. 
APPENDIX D

LIST OF STANDARD ERRORS OF THE MODEL RESULTS 


\section{LIST DI}

LIST OF STANDARD ERRORS FOR NONADJACENT COUNTIES LABOR OUT-MIGRATION MODEL

\begin{tabular}{|c|c|c|c|c|c|c|c|c|c|}
\hline \multicolumn{3}{|c|}{$1960-65$} & \multicolumn{3}{|c|}{$1965-70$} & \multicolumn{3}{|c|}{$1970-\sqrt{3}$} & \multirow[b]{2}{*}{ SE } \\
\hline & BETA & T for Ho: & SE & BETA & T for Ho: & SE & BETA & T for Ho: & \\
\hline COASTANT & 0.207 & 0.089 & 2.323 & 5.466 & 5.550 & 0.985 & 3.935 & 3.492 & 1.127 \\
\hline \multicolumn{10}{|l|}{$\begin{array}{l}\text { EMPLOYMENT VARIABLES } \\
\text { MPL }\end{array}$} \\
\hline $\begin{array}{l}\text { BASIC EMPLOYMENT } \\
\text { HOHBASIC EMPLOYMENT }\end{array}$ & $\begin{array}{l}-0.001 \\
-0.026\end{array}$ & $\begin{array}{l}-0.097 \\
-1.137\end{array}$ & $\begin{array}{l}0.011 \\
0.023\end{array}$ & $\begin{array}{l}-0.062 \\
-0.005\end{array}$ & $\begin{array}{l}-5.088 \\
-0.980\end{array}$ & $\begin{array}{l}0.012 \\
0.005\end{array}$ & $\begin{array}{r}-0.047 \\
0.001\end{array}$ & $\begin{array}{r}-4.409 \\
0.170\end{array}$ & $\begin{array}{l}0.011 \\
0.008\end{array}$ \\
\hline \multicolumn{10}{|l|}{ ENVIRONMENTAL AHENITIES } \\
\hline $\begin{array}{l}\text { COLLEGE } \\
\text { EXPENDITURES } \\
\text { RECREATION } \\
\text { IKCOME }\end{array}$ & $\begin{array}{r}0.002 \\
0.007 \\
0.008 \\
-0.477\end{array}$ & $\begin{array}{r}0.836 \\
0.862 \\
1.200 \\
-1.607\end{array}$ & $\begin{array}{l}0.002 \\
0.008 \\
0.007 \\
0.297\end{array}$ & $\begin{array}{r}0.001 \\
-0.006 \\
0.009 \\
0.214\end{array}$ & $\begin{array}{r}1.016 \\
-1.848 \\
2.140 \\
1.612\end{array}$ & $\begin{array}{l}0.001 \\
0.003 \\
0.004 \\
0.133\end{array}$ & $\begin{array}{r}-0.005 \\
-0.001 \\
0.002 \\
0.093\end{array}$ & $\begin{array}{r}-0.791 \\
-0.385 \\
0.493 \\
0.568\end{array}$ & $\begin{array}{l}0.007 \\
0.003 \\
0.003 \\
0.164\end{array}$ \\
\hline \multicolumn{10}{|c|}{ ENVIRONMEHTAL DISAMENITIES } \\
\hline $\begin{array}{l}\text { AGE DEPENDENCY } \\
\text { UWEMPLOYYMENT } \\
\text { NONHHIIE } \\
\text { CRIME } \\
\text { CLIMAIE } \\
\text { HOUSING }\end{array}$ & $\begin{array}{r}-0.163 \\
0.002 \\
0.018 \\
0.027 \\
-0.054 \\
0.037\end{array}$ & $\begin{array}{r}-2.118 \\
0.820 \\
2.370 \\
0.726 \\
-1.186 \\
0.890\end{array}$ & $\begin{array}{l}0.077 \\
0.003 \\
0.007 \\
0.037 \\
0.046 \\
0.041\end{array}$ & $\begin{array}{r}-0.021 \\
0.001 \\
-0.003 \\
0.025 \\
-0.087 \\
-0.028\end{array}$ & $\begin{array}{r}-0.396 \\
1.345 \\
-0.807 \\
4.688 \\
-3.306 \\
-1.310\end{array}$ & $\begin{array}{l}0.053 \\
0.001 \\
0.004 \\
0.005 \\
0.026 \\
0.021\end{array}$ & $\begin{array}{r}-0.033 \\
-0.000 \\
-0.001 \\
0.040 \\
-0.043 \\
-0.021\end{array}$ & $\begin{array}{r}-0.816 \\
-0.067 \\
-0.100 \\
9.417 \\
-2.140 \\
-1.122\end{array}$ & $\begin{array}{l}0.040 \\
0.001 \\
0.005 \\
0.004 \\
0.020 \\
0.019\end{array}$ \\
\hline \multicolumn{10}{|l|}{ ACCESSIBILITY } \\
\hline $\begin{array}{l}\text { GRAVITY } \\
\text { CONTIGUOUS } \\
\text { POPULATION }\end{array}$ & $\begin{array}{r}0.036 \\
2.336 \\
-0.970\end{array}$ & $\begin{array}{r}10.333 \\
0.790 \\
-24.021\end{array}$ & $\begin{array}{l}0.003 \\
2.957 \\
0.040\end{array}$ & $\begin{array}{r}0.092 \\
0.900 \\
-1.092\end{array}$ & $\begin{array}{r}10.164 \\
1.521 \\
-53.792\end{array}$ & $\begin{array}{l}0.009 \\
0.591 \\
0.020\end{array}$ & $\begin{array}{r}0.073 \\
0.200 \\
-1.044\end{array}$ & $\begin{array}{r}7.169 \\
0.359 \\
-55.470\end{array}$ & $\begin{array}{l}0.010 \\
0.556 \\
0.019\end{array}$ \\
\hline $\begin{array}{l}\text { F-VALUE } \\
\text { PROB }> \\
\text { R SOUARE } \\
\text { AOJUSTED R } \\
\text { EXPLAINED SUM SQUARES } \\
\text { ERROR SUM SOUARES }\end{array}$ & $\begin{array}{r}3565.429 \\
0.000 \\
0.879 \\
0.879 \\
10351.254 \\
1427.227\end{array}$ & & & $\begin{array}{r}7877.195 \\
0.000 \\
0.941 \\
0.941 \\
10064 \\
628\end{array}$ & & & $\begin{array}{r}1764.322 \\
0.000 \\
0.960 \\
0.960 \\
10082 \\
421\end{array}$ & & \\
\hline
\end{tabular}


LIST D2

LIST OF STANDARD ERRORS FOR NONADJACENT LABOR OUT-MIGRATION BASIC EMPLOYMENT MODEL

\begin{tabular}{|c|c|c|c|c|c|c|c|c|c|}
\hline \multirow{2}{*}{ (n) } & \multicolumn{2}{|c|}{$1960-65$} & \multicolumn{3}{|c|}{$1965-70$} & \multicolumn{3}{|c|}{$1970-75$} & \multirow[b]{2}{*}{ SE } \\
\hline & BETA & $T$ for Ho: & SE & BETA & T for Ho: & SE & BETA & T for Ho: & \\
\hline CONSTANT & 3.828 & 42.758 & 0.090 & 1.967 & 14.139 & 0.139 & 2.906 & 22.117 & 0.131 \\
\hline \multicolumn{10}{|l|}{ EXOGEKOUS VARIABLES } \\
\hline $\begin{array}{l}\text { LABOR MIGRATION FLOWS } \\
\text { MOHBASIC EMPLOYMENT }\end{array}$ & $\begin{array}{l}0.055 \\
0.624\end{array}$ & $\begin{array}{r}3.589 \\
14.560\end{array}$ & $\begin{array}{l}0.015 \\
0.043\end{array}$ & $\begin{array}{r}0.478 \\
-0.725\end{array}$ & $\begin{array}{r}23.670 \\
-60.169\end{array}$ & $\begin{array}{l}0.020 \\
0.012\end{array}$ & $\begin{array}{r}0.237 \\
-0.863\end{array}$ & $\begin{array}{r}11.837 \\
-73.494\end{array}$ & $\begin{array}{l}0.020 \\
0.012\end{array}$ \\
\hline \multicolumn{10}{|l|}{ INDEPEHDEHT VARIABLES } \\
\hline $\begin{array}{l}\text { AGRICULTURAL SERVICES } \\
\text { ROUTINE HAMUFACTURING } \\
\text { PROOUCER } \\
\text { ENERGY } \\
\text { HAGES } \\
\text { FREEWAY }\end{array}$ & $\begin{array}{r}-0.162 \\
-0.476 \\
0.226 \\
-0.401 \\
1.205 \\
0.301\end{array}$ & $\begin{array}{r}-9.116 \\
-14.427 \\
4.533 \\
-11.767 \\
14.564 \\
6.471\end{array}$ & $\begin{array}{l}0.018 \\
0.033 \\
0.050 \\
0.034 \\
0.083 \\
0.047\end{array}$ & $\begin{array}{r}-0.137 \\
-0.346 \\
0.208 \\
-0.068 \\
-0.087 \\
-0.208\end{array}$ & $\begin{array}{r}-4.976 \\
-7.074 \\
5.884 \\
-1.333 \\
-0.922 \\
-1.420\end{array}$ & $\begin{array}{l}0.028 \\
0.049 \\
0.035 \\
0.051 \\
0.094 \\
0.146\end{array}$ & $\begin{array}{r}-0.136 \\
-0.238 \\
0.142 \\
0.006 \\
-0.126 \\
-0.917\end{array}$ & $\begin{array}{r}-5.156 \\
-5.076 \\
4.151 \\
0.113 \\
-1.397 \\
-6.491\end{array}$ & $\begin{array}{l}0.026 \\
0.047 \\
0.034 \\
0.049 \\
0.090 \\
0.141\end{array}$ \\
\hline $\begin{array}{l}\text { F VALUE } \\
\text { PROB }> \\
\text { R SQUARE } \\
\text { ADJUSTED R } \\
\text { EXPLAINED SUH SQUARES } \\
\text { ERROR SUH SOUARES }\end{array}$ & $\begin{array}{r}212.190 \\
0.000 \\
0.187 \\
0.186 \\
2356.925 \\
10248.142\end{array}$ & & & $\begin{array}{r}838.828 \\
0.000 \\
0.476 \\
0.476 \\
19288 \\
21215\end{array}$ & & & $\begin{array}{r}1071.005 \\
0.000 \\
0.537 \\
0.537 \\
22736 \\
19586\end{array}$ & & \\
\hline
\end{tabular}


LIST D3

LIST OF STANDARD ERRORS FOR NONADJACENT LABOR OUT-MIGRATION NONBASIC EMPLOYMENT

\begin{tabular}{|c|c|c|c|c|c|c|c|c|c|}
\hline \multirow{3}{*}{$\begin{array}{l}\text { CONSTAHT } \\
\text { COH }\end{array}$} & \multicolumn{2}{|c|}{$1960-65$} & \multicolumn{3}{|c|}{$1965-70$} & \multicolumn{4}{|c|}{$1970-75$} \\
\hline & BETA & $T$ for Ho: & SE & BETA & T for Ho: & SE & BETA & $T$ for Ho: & SE \\
\hline & -9.124 & -9.113 & 0.123 & 2.536 & 8.083 & 0.314 & 5.042 & 18.711 & \\
\hline \multicolumn{10}{|l|}{ ENDOGENOUS VARIABLES } \\
\hline $\begin{array}{l}\text { LABOR MIGRATION FLOUS } \\
\text { BASIC EMPLOYMENT }\end{array}$ & $\begin{array}{l}0.111 \\
0.029\end{array}$ & $\begin{array}{l}7.475 \\
2.755\end{array}$ & $\begin{array}{l}0.015 \\
0.010\end{array}$ & $\begin{array}{r}0.707 \\
-1.149\end{array}$ & $\begin{array}{r}17.219 \\
-61.281\end{array}$ & $\begin{array}{l}0.041 \\
0.019\end{array}$ & $\begin{array}{r}0.335 \\
-1.041\end{array}$ & $\begin{array}{r}9.803 \\
-72.095\end{array}$ & $\begin{array}{l}0.034 \\
0.014\end{array}$ \\
\hline \multicolumn{10}{|l|}{ INDEPEHDENT VARIABLES } \\
\hline $\begin{array}{l}\text { PERSONAL SERVICES/RETAIL } \\
\text { GOVERNMENT } \\
\text { RETIREMENT } \\
\text { WAGES }\end{array}$ & $\begin{array}{l}-0.137 \\
-0.099 \\
-0.193 \\
-0.352\end{array}$ & $\begin{array}{l}-1.142 \\
-3.594 \\
-7.369 \\
-3.422\end{array}$ & $\begin{array}{l}0.120 \\
0.027 \\
0.026 \\
0.103\end{array}$ & $\begin{array}{r}1.090 \\
-0.164 \\
-0.232 \\
-0.464\end{array}$ & $\begin{array}{l}5.537 \\
-2.072 \\
-2.185 \\
-2.572\end{array}$ & $\begin{array}{l}0.197 \\
0.079 \\
0.106 \\
0.180\end{array}$ & $\begin{array}{r}0.010 \\
-0.344 \\
0.527 \\
0.210\end{array}$ & $\begin{array}{r}0.058 \\
-5.081 \\
5.788 \\
1.363\end{array}$ & $\begin{array}{l}0.164 \\
0.068 \\
0.091 \\
0.154\end{array}$ \\
\hline $\begin{array}{l}\text { F VALUE } \\
\text { PROB }>F \\
\text { R SQUARE } \\
\text { DDJUSTED R } \\
\text { EXPLAINED SUM SQUARES } \\
\text { ERROR SUM SOUARES }\end{array}$ & $\begin{array}{r}224.119 \\
0.000 \\
0.154 \\
0.153 \\
731.088 \\
4013.949\end{array}$ & & & $\begin{array}{r}756.336 \\
0.000 \\
0.381 \\
0.380 \\
19867 \\
32323\end{array}$ & & & $\begin{array}{r}1170.291 \\
0.000 \\
0.488 \\
0.487 \\
22496 \\
23653\end{array}$ & & \\
\hline
\end{tabular}


LIST D4

LIST OF STANDARD ERRORS FOR NONADJACENT COUNTIES

LABOR IN-MIGRATION MODEL

\begin{tabular}{|c|c|c|c|c|c|c|c|c|c|}
\hline \multirow{2}{*}{ (n) } & \multicolumn{2}{|c|}{$1960-65$} & \multicolumn{3}{|c|}{$1965-70$} & \multicolumn{4}{|c|}{$1970-75$} \\
\hline & BETA & $T$ for Ho: & SE & BETA & T for Ho: & SE & BETA & $T$ for Ho: & SE \\
\hline CONSTANT & 3.372 & 6.945 & 0.486 & 9.190 & 1.686 & 5.451 & 4.571 & 4.427 & 1.033 \\
\hline \multicolumn{10}{|l|}{ EMPLOYMENT VARIABLES } \\
\hline $\begin{array}{l}\text { BASIC EMPLOYAENT } \\
\text { KONBASIC EMPLOYMENT }\end{array}$ & $\begin{array}{r}0.011 \\
-0.004\end{array}$ & $\begin{array}{r}1.340 \\
-0.230\end{array}$ & $\begin{array}{l}0.008 \\
0.017\end{array}$ & $\begin{array}{l}-0.003 \\
-0.012\end{array}$ & $\begin{array}{l}-0.109 \\
-0.273\end{array}$ & $\begin{array}{l}0.026 \\
0.045\end{array}$ & $\begin{array}{r}-0.002 \\
0.004\end{array}$ & $\begin{array}{r}-0.147 \\
0.189\end{array}$ & $\begin{array}{l}0.012 \\
0.021\end{array}$ \\
\hline \multicolumn{10}{|l|}{ ENVIRONMENTAL AMENITIES } \\
\hline $\begin{array}{l}\text { COLLEGE } \\
\text { EXPEHD ITURES } \\
\text { RECREATION } \\
\text { IHCOME }\end{array}$ & $\begin{array}{r}0.001 \\
-0.007 \\
0.009 \\
0.015\end{array}$ & $\begin{array}{r}0.952 \\
-2.792 \\
2.588 \\
0.242\end{array}$ & $\begin{array}{l}0.001 \\
0.003 \\
0.004 \\
0.064\end{array}$ & $\begin{array}{r}0.004 \\
-0.001 \\
0.017 \\
0.843\end{array}$ & $\begin{array}{r}1.250 \\
-0.112 \\
1.286 \\
1.075\end{array}$ & $\begin{array}{l}0.003 \\
0.008 \\
0.014 \\
0.784\end{array}$ & $\begin{array}{r}0.006 \\
-0.002 \\
0.012 \\
0.195\end{array}$ & $\begin{array}{r}1.960 \\
-0.425 \\
1.712 \\
1.464\end{array}$ & $\begin{array}{l}0.003 \\
0.004 \\
0.007 \\
0.133\end{array}$ \\
\hline \multicolumn{10}{|c|}{ EHVIRONMENTAL DISAMENITIES } \\
\hline $\begin{array}{l}\text { AGE DEPENDEHCY } \\
\text { UNEMPLOYMENT } \\
\text { ROHWHITE } \\
\text { CRIME } \\
\text { CLIMATE } \\
\text { HOUSIKG }\end{array}$ & $\begin{array}{r}-0.110 \\
-0.002 \\
0.003 \\
0.014 \\
-0.008 \\
-0.074\end{array}$ & $\begin{array}{r}-3.061 \\
-2.037 \\
1.169 \\
2.552 \\
-0.478 \\
-3.402\end{array}$ & $\begin{array}{l}0.036 \\
0.001 \\
0.003 \\
0.005 \\
0.016 \\
0.022\end{array}$ & $\begin{array}{r}0.107 \\
0.001 \\
0.001 \\
0.037 \\
-0.052 \\
0.026\end{array}$ & $\begin{array}{r}0.575 \\
0.225 \\
0.076 \\
1.007 \\
-0.659 \\
0.355\end{array}$ & $\begin{array}{l}0.186 \\
0.005 \\
0.017 \\
0.037 \\
0.079 \\
0.074\end{array}$ & $\begin{array}{r}0.065 \\
-0.002 \\
-0.001 \\
0.026 \\
-0.025 \\
0.021\end{array}$ & $\begin{array}{r}0.662 \\
-0.835 \\
-0.097 \\
1.354 \\
-0.592 \\
0.511\end{array}$ & $\begin{array}{l}0.098 \\
0.002 \\
0.009 \\
0.019 \\
0.041 \\
0.040\end{array}$ \\
\hline \multicolumn{10}{|l|}{ ACCESSIBILITY } \\
\hline $\begin{array}{l}\text { GRAVITY } \\
\text { COHTIGUOUS } \\
\text { POPULATION }\end{array}$ & $\begin{array}{r}0.039 \\
-0.155 \\
-0.992 \\
\end{array}$ & $\begin{array}{r}7.371 \\
-0.479 \\
-84.723 \\
\end{array}$ & $\begin{array}{l}0.005 \\
0.324 \\
0.012\end{array}$ & $\begin{array}{r}0.025 \\
5.336 \\
-0.974\end{array}$ & $\begin{array}{r}2.525 \\
1.570 \\
-21.103\end{array}$ & $\begin{array}{l}0.010 \\
3.399 \\
0.046\end{array}$ & $\begin{array}{r}0.040 \\
2.592 \\
-0.991\end{array}$ & $\begin{array}{r}11.588 \\
1.442 \\
-43.174\end{array}$ & $\begin{array}{l}0.003 \\
1.798 \\
0.023\end{array}$ \\
\hline $\begin{array}{l}\text { F-VALUE } \\
\text { PROB }> \\
\text { R SOUARE } \\
\text { ADJUSTED R } \\
\text { EXPLAIHED SUM SQUARES } \\
\text { ERROR SUA SQUARES }\end{array}$ & $\begin{array}{r}17179.910 \\
0.000 \\
0.972 \\
0.972 \\
17317 \\
488\end{array}$ & & & $\begin{array}{r}828.929 \\
0.000 \\
0.628 \\
0.627 \\
10297 \\
6103\end{array}$ & & & $\begin{array}{r}3083.090 \\
0.000 \\
0.863 \\
0.862 \\
10203 \\
1626\end{array}$ & & \\
\hline
\end{tabular}


LIST D5

LIST OF STANDARD ERROR FOR NONADJACENT BASIC EMPLOYMENT LABOR IN-MIGRATION MODEL

\begin{tabular}{|c|c|c|c|c|c|c|c|c|c|}
\hline & \multicolumn{2}{|c|}{$1960-65$} & & \multicolumn{2}{|c|}{$1965-70$} & \multicolumn{3}{|c|}{$1970-75$} & \\
\hline & BETA & $T$ for Ho: & SE & BETR & T for Ho: & SE & BETA & T for Ho: & SE \\
\hline CONSTANT & 2.591 & 23.256 & 0.111 & 2.390 & 39.911 & 0.060 & 2.532 & 40.908 & 0.062 \\
\hline \multicolumn{10}{|l|}{ EXOGEHOUS VARIABLES } \\
\hline $\begin{array}{l}\text { LABOR AIGRATIOH FLONS } \\
\text { HOWBASIC EMPLOYMENT }\end{array}$ & $\begin{array}{r}-0.064 \\
0.535\end{array}$ & $\begin{array}{r}-4.641 \\
8.465\end{array}$ & $\begin{array}{l}0.014 \\
0.063\end{array}$ & $\begin{array}{l}0.178 \\
0.532\end{array}$ & $\begin{array}{l}18.734 \\
15.270\end{array}$ & $\begin{array}{l}0.009 \\
0.035\end{array}$ & $\begin{array}{l}0.187 \\
0.523\end{array}$ & $\begin{array}{l}19.979 \\
15.678\end{array}$ & $\begin{array}{l}0.009 \\
0.034\end{array}$ \\
\hline \multicolumn{10}{|l|}{ INDEPENDENT VAPIABLES } \\
\hline $\begin{array}{l}\text { AGRICULTURAL SERVICES } \\
\text { ROUITINE MANUFACTURING } \\
\text { PROOUCER } \\
\text { EHERGY } \\
\text { WAGES } \\
\text { FREEWAY }\end{array}$ & $\begin{array}{r}-0.036 \\
-0.458 \\
0.163 \\
0.152 \\
0.713 \\
-0.181\end{array}$ & $\begin{array}{r}-1.672 \\
-15.398 \\
2.315 \\
3.998 \\
7.356 \\
-4.637\end{array}$ & $\begin{array}{l}0.022 \\
0.030 \\
0.070 \\
0.038 \\
0.097 \\
0.039\end{array}$ & $\begin{array}{r}-0.021 \\
-0.185 \\
0.198 \\
-0.194 \\
0.554 \\
1.130\end{array}$ & $\begin{array}{r}-1.460 \\
-9.319 \\
8.027 \\
-8.564 \\
12.077 \\
15.271\end{array}$ & $\begin{array}{l}0.014 \\
0.020 \\
0.025 \\
0.023 \\
0.046 \\
0.074\end{array}$ & $\begin{array}{r}-0.055 \\
-0.218 \\
0.321 \\
-0.238 \\
0.557 \\
1.281\end{array}$ & $\begin{array}{r}-3.879 \\
-9.993 \\
11.153 \\
-10.207 \\
10.626 \\
16.670\end{array}$ & $\begin{array}{l}0.014 \\
0.022 \\
0.029 \\
0.023 \\
0.052 \\
0.077\end{array}$ \\
\hline $\begin{array}{l}\text { F VALUE } \\
\text { PROB }> \\
R \text { SQUARE } \\
\text { ADJUSTED R } \\
\text { EXPLAIMED SUM SQUARES } \\
\text { ERROR SUH SOUARES }\end{array}$ & $\begin{array}{r}131.624 \\
0.000 \\
0.125 \\
0.124 \\
1387 \\
9728\end{array}$ & & & $\begin{array}{r}166.162 \\
0.000 \\
0.168 \\
0.167 \\
932 \\
4615\end{array}$ & & & $\begin{array}{r}220.262 \\
0.000 \\
0.193 \\
0.192 \\
1152 \\
4824\end{array}$ & & \\
\hline
\end{tabular}


LIST D6

LIST OF STANDARD ERRORS FOR NONADJACENT NONBASIC EMPLOYMENT LABOR IN-MIGRATION MODEL

\begin{tabular}{|c|c|c|c|c|c|c|c|c|c|}
\hline \multirow{3}{*}{ CONSTANT } & \multicolumn{2}{|c|}{$1960-65$} & \multicolumn{3}{|c|}{$1965-70$} & \multicolumn{3}{|c|}{$1970 \cdot 75$} & \multirow[b]{2}{*}{ SE } \\
\hline & BETA & $T$ for Ho: & SE & BETA & T for Ho: & SE & BETA & T for Ho: & \\
\hline & -0.437 & -4.756 & & -0.213 & -2.154 & & 1.200 & 9.026 & \\
\hline \multicolumn{10}{|l|}{ ENDOGEHOUS VARIABLES } \\
\hline $\begin{array}{l}\text { LABOR MIGRATION FLLNS } \\
\text { BASIC EMPLOYMENT }\end{array}$ & $\begin{array}{l}0.125 \\
0.049\end{array}$ & $\begin{array}{r}11.145 \\
2.956\end{array}$ & $\begin{array}{l}0.011 \\
0.017\end{array}$ & $\begin{array}{l}-0.015 \\
-0.059\end{array}$ & $\begin{array}{l}-1.223 \\
-3.938\end{array}$ & $\begin{array}{l}0.012 \\
0.015\end{array}$ & $\begin{array}{l}-0.010 \\
-0.101\end{array}$ & $\begin{array}{l}-0.624 \\
-6.193\end{array}$ & $\begin{array}{l}0.015 \\
0.016\end{array}$ \\
\hline \multicolumn{10}{|l|}{ INDEPENDEKT VARIABLES } \\
\hline $\begin{array}{l}\text { PERSONAL SERVICES/RETAIL } \\
\text { GOVERNMENT } \\
\text { RETIREMENT } \\
\text { WAGES }\end{array}$ & $\begin{array}{r}-0.762 \\
-0.085 \\
0.021 \\
0.582\end{array}$ & $\begin{array}{l}-6.559 \\
-2.738 \\
0.716 \\
5.703\end{array}$ & $\begin{array}{l}0.116 \\
0.031 \\
0.029 \\
0.102\end{array}$ & $\begin{array}{r}0.213 \\
-0.251 \\
0.164 \\
-0.715\end{array}$ & $\begin{array}{r}3.566 \\
-9.442 \\
6.874 \\
-12.886\end{array}$ & $\begin{array}{l}0.060 \\
0.027 \\
0.024 \\
0.055\end{array}$ & $\begin{array}{r}-1.278 \\
-0.386 \\
0.438 \\
0.494\end{array}$ & $\begin{array}{r}-10.028 \\
-13.084 \\
16.708 \\
4.445\end{array}$ & $\begin{array}{l}0.127 \\
0.030 \\
0.026 \\
0.111\end{array}$ \\
\hline $\begin{array}{l}\text { F VALUE } \\
\text { PROB > F } \\
\text { R SQLIARE } \\
\text { AD JUSTED R } \\
\text { EXPLAINED SUM SQUARES } \\
\text { ERROR SUM SQUARES }\end{array}$ & $\begin{array}{r}56.739 \\
0.000 \\
0.044 \\
0.043 \\
210 \\
4572\end{array}$ & & & $\begin{array}{r}152.757 \\
0.000 \\
0.111 \\
0.110 \\
392 \\
3158\end{array}$ & & & $\begin{array}{r}128.917 \\
0.000 \\
0.095 \\
0.094 \\
388 \\
3706\end{array}$ & & \\
\hline
\end{tabular}


LIST D7

LIST OF STANDARD ERRORS FOR ADJACENT COUNTIES LABOR OUT-MIGRATION MODEL

\begin{tabular}{|c|c|c|c|c|c|c|c|c|c|}
\hline \multirow{2}{*}{ (n) } & \multicolumn{2}{|c|}{$1900-65$} & \multicolumn{3}{|c|}{$1965-70$} & \multicolumn{4}{|c|}{$1970-75$} \\
\hline & BETA & T for Ho: & SE & BETA & $T$ for Ho: & SE & BETA & $T$ for Ho: & SE \\
\hline CONSTANT & 3.123 & 2.045 & 1.527 & 2.337 & 1.261 & 1.853 & 1.752 & 0.830 & 2.111 \\
\hline \multicolumn{10}{|l|}{ EMPLOYMENT VARIABLES } \\
\hline $\begin{array}{l}\text { BASIC EMPLOYMENT } \\
\text { NOHBASIC EMPLOYMENT }\end{array}$ & $\begin{array}{l}-0.006 \\
-0.052\end{array}$ & $\begin{array}{l}-0.905 \\
-3.753\end{array}$ & $\begin{array}{l}0.006 \\
0.014\end{array}$ & $\begin{array}{l}-0.003 \\
-0.030\end{array}$ & $\begin{array}{l}-0.077 \\
-1.697\end{array}$ & $\begin{array}{l}0.037 \\
0.018\end{array}$ & $\begin{array}{l}-0.047 \\
-0.033\end{array}$ & $\begin{array}{l}-1.583 \\
-2.010\end{array}$ & $\begin{array}{l}0.029 \\
0.016\end{array}$ \\
\hline \multicolumn{10}{|l|}{ ENVIRONMENTAL AMENITIES } \\
\hline $\begin{array}{l}\text { COLLEGE } \\
\text { EXPEND ITURES } \\
\text { RECREATION } \\
\text { INCOHE }\end{array}$ & $\begin{array}{r}0.002 \\
-0.008 \\
-0.000 \\
-0.029\end{array}$ & $\begin{array}{r}0.498 \\
-1.297 \\
-0.001 \\
-0.133\end{array}$ & $\begin{array}{l}0.004 \\
0.006 \\
0.005 \\
0.218\end{array}$ & $\begin{array}{r}-0.003 \\
-0.012 \\
0.007 \\
0.016\end{array}$ & $\begin{array}{r}-0.641 \\
-1.521 \\
1.115 \\
0.065\end{array}$ & $\begin{array}{l}0.005 \\
0.008 \\
0.006 \\
0.245\end{array}$ & $\begin{array}{r}0.006 \\
-0.008 \\
0.003 \\
-0.171\end{array}$ & $\begin{array}{r}0.564 \\
-1.115 \\
0.416 \\
-0.580\end{array}$ & $\begin{array}{l}0.011 \\
0.007 \\
0.006 \\
0.295\end{array}$ \\
\hline \multicolumn{10}{|c|}{ ENVIRONMENTAL DISAMENITIES } \\
\hline $\begin{array}{l}\text { AGE DEPENDENCY } \\
\text { UNEMPLOYMENT } \\
\text { NOHWHITE } \\
\text { CRIME } \\
\text { CLIMATE } \\
\text { HOUSING }\end{array}$ & $\begin{array}{r}-0.080 \\
-0.001 \\
-0.016 \\
-0.001 \\
-0.023 \\
0.005\end{array}$ & $\begin{array}{r}-0.981 \\
-0.346 \\
-1.974 \\
-0.102 \\
-0.967 \\
0.147\end{array}$ & $\begin{array}{l}0.081 \\
0.002 \\
0.008 \\
0.007 \\
0.024 \\
0.035\end{array}$ & $\begin{array}{r}-0.160 \\
-0.002 \\
0.012 \\
0.027 \\
0.012 \\
-0.014\end{array}$ & $\begin{array}{r}-1.517 \\
-0.728 \\
0.991 \\
2.850 \\
0.378 \\
-0.349\end{array}$ & $\begin{array}{l}0.106 \\
0.002 \\
0.012 \\
0.009 \\
0.032 \\
0.040\end{array}$ & $\begin{array}{r}-0.192 \\
-0.002 \\
0.010 \\
0.025 \\
-0.017 \\
-0.070\end{array}$ & $\begin{array}{r}-3.427 \\
-0.846 \\
0.870 \\
3.059 \\
-0.576 \\
-2.176\end{array}$ & $\begin{array}{l}0.056 \\
0.002 \\
0.011 \\
0.008 \\
0.029 \\
0.032\end{array}$ \\
\hline \multicolumn{10}{|l|}{ ACCESSIBILITY } \\
\hline $\begin{array}{l}\text { GRAVITY } \\
\text { CONIIGUOUS } \\
\text { POPULATION }\end{array}$ & $\begin{array}{r}0.047 \\
-0.294 \\
-1.008\end{array}$ & $\begin{array}{r}7.158 \\
-0.414 \\
-76.943\end{array}$ & $\begin{array}{l}0.007 \\
0.710 \\
0.013\end{array}$ & $\begin{array}{r}0.043 \\
-0.964 \\
-0.917\end{array}$ & $\begin{array}{r}1.035 \\
-0.860 \\
-9.899\end{array}$ & $\begin{array}{l}0.042 \\
1.121 \\
0.093\end{array}$ & $\begin{array}{r}0.052 \\
-1.059 \\
-0.978\end{array}$ & $\begin{array}{r}1.707 \\
-1.096 \\
-i 3.666\end{array}$ & $\begin{array}{l}0.031 \\
0.956 \\
0.072\end{array}$ \\
\hline $\begin{array}{l}\text { F-VALUE } \\
\text { PROB }> \\
\text { R SOUARE } \\
\text { AD JUSTED R } \\
\text { EXPLAIKED SLM SOUARES } \\
\text { ERROR SUM SGUARES }\end{array}$ & $\begin{array}{r}3077.705 \\
0.000 \\
0.895 \\
0.895 \\
4157 \\
486\end{array}$ & & & $\begin{array}{r}1822.601 \\
0.000 \\
0.835 \\
0.835 \\
4466 \\
1922\end{array}$ & & & $\begin{array}{r}2069.167 \\
0.000 \\
0.852 \\
0.852 \\
4508 \\
783\end{array}$ & & \\
\hline
\end{tabular}




\section{LIST D8}

LIST OF STANDARD ERRORS FOR ADJACENT LABOR OUT-MIGRATION BASIC EMPLOYMENT MODEL

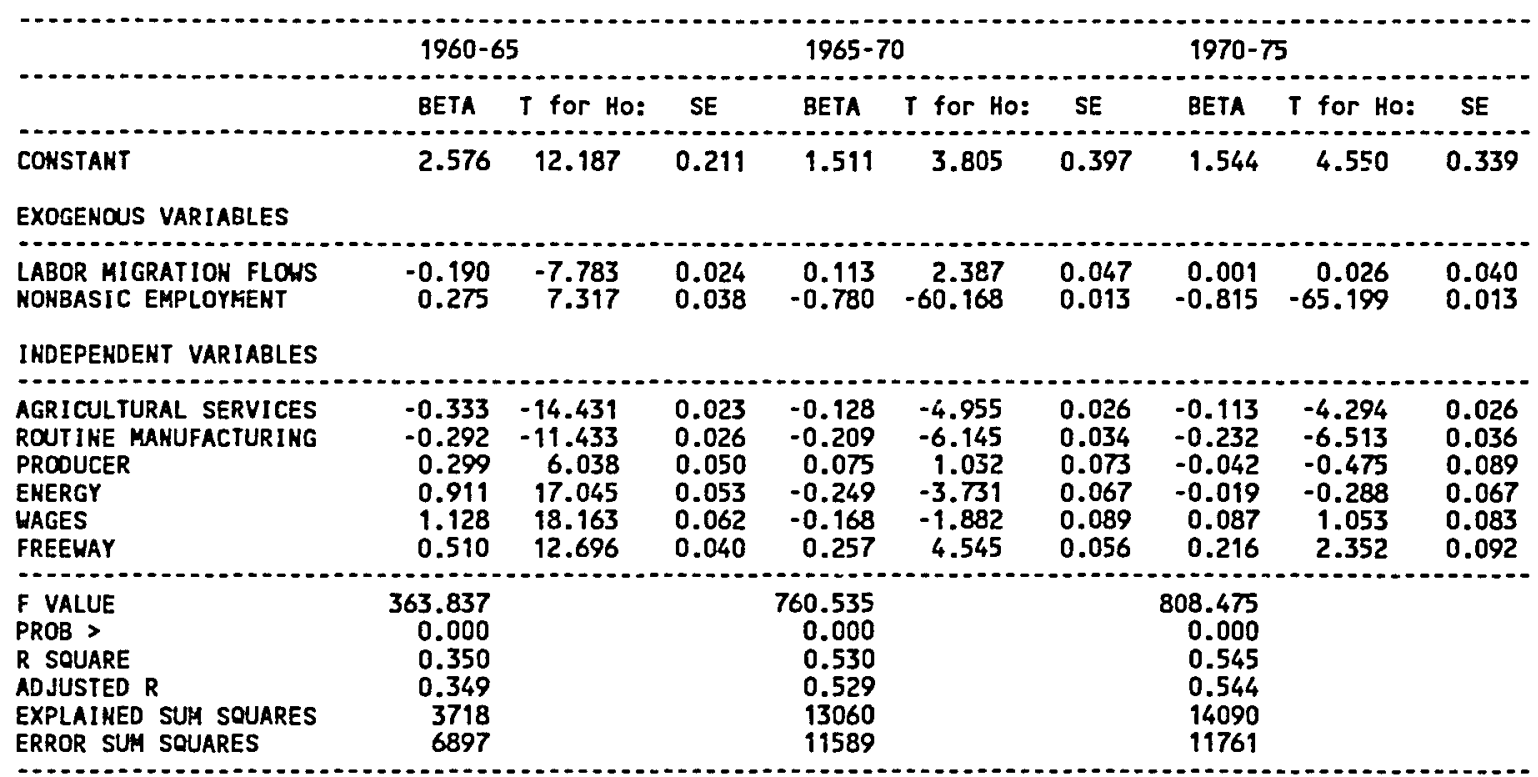


LIST D9

\section{LIST OF STANDARD ERRORS FOR ADJACENT LABOR} OUT-MIGRATION BASIC EMPLOYMENT MODEL

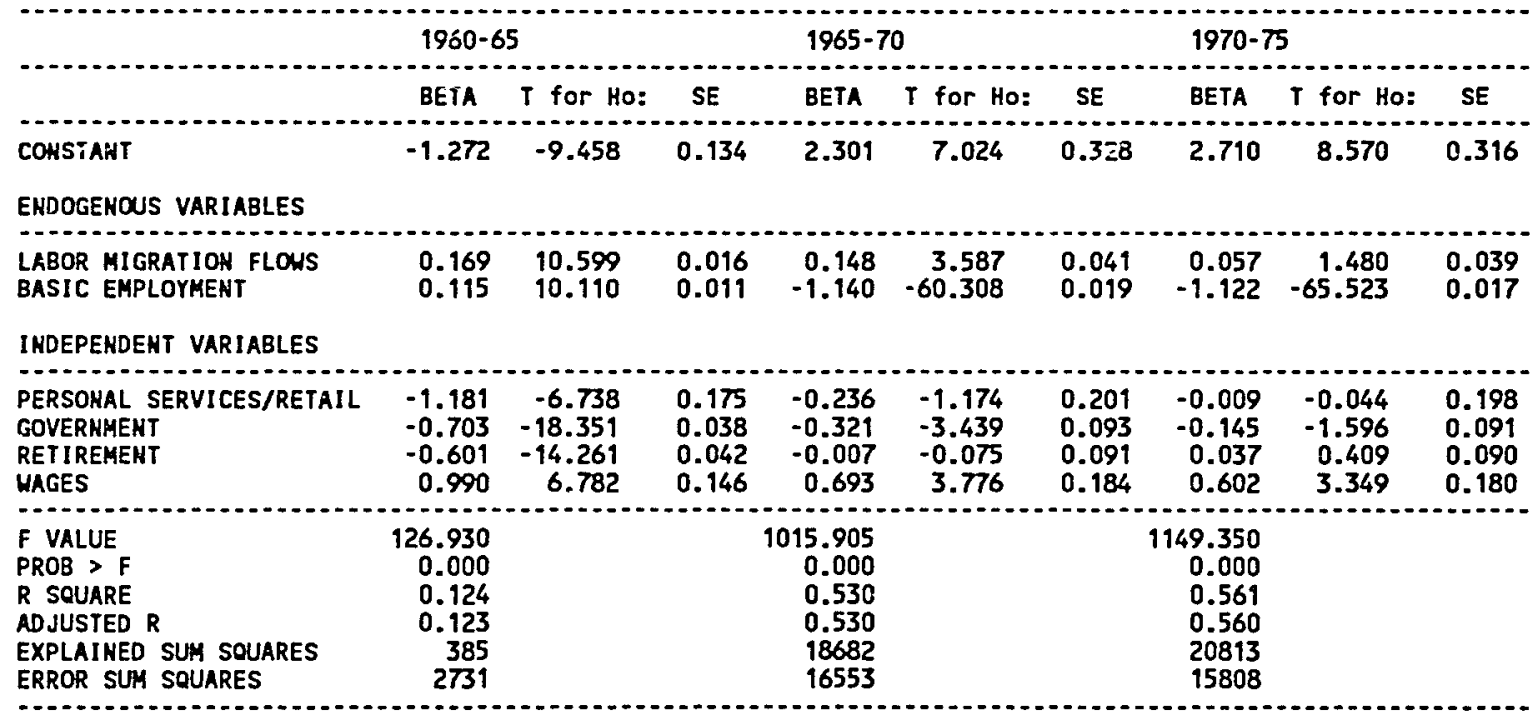




\section{LIST D10}

\section{LIST OF STANDARD ERROR FOR ADJACENT COUNTY}

\section{LABOR IN-MIGRATION MODEL}

\begin{tabular}{|c|c|c|c|c|c|c|c|c|c|}
\hline \multirow{2}{*}{ (n) } & \multicolumn{2}{|c|}{$1960-65$} & \multicolumn{3}{|c|}{$1965-70$} & \multicolumn{3}{|c|}{$1970-75$} & \multirow[b]{2}{*}{ SE } \\
\hline & BETA & T for Ho: & SE & BETA & T for Ho: & SE & BETA & T for Ho: & \\
\hline COHSTANT & 2.430 & 3.348 & 0.726 & -1.574 & -0.796 & 1.978 & 2.276 & 3.076 & 0.740 \\
\hline \multicolumn{10}{|l|}{ EMPLOYMENT VARIABLES } \\
\hline $\begin{array}{l}\text { BRSIC EMPLOYMENT } \\
\text { HONBASIC EMPLOYMENT }\end{array}$ & $\begin{array}{r}0.026 \\
-0.048\end{array}$ & $\begin{aligned} & 1.922 \\
&-1.714\end{aligned}$ & $\begin{array}{l}0.013 \\
0.028\end{array}$ & $\begin{array}{r}0.003 \\
-0.008\end{array}$ & $\begin{array}{r}0.158 \\
-0.140\end{array}$ & $\begin{array}{l}0.018 \\
0.056\end{array}$ & $\begin{array}{l}0.010 \\
0.026\end{array}$ & $\begin{array}{l}0.837 \\
0.575\end{array}$ & $\begin{array}{l}0.012 \\
0.045\end{array}$ \\
\hline \multicolumn{10}{|l|}{ ENVIRONMEHTAL AMENITIES } \\
\hline $\begin{array}{l}\text { COLLEGE } \\
\text { EXPENDI IURES } \\
\text { RECREATION } \\
\text { INCOAE }\end{array}$ & $\begin{array}{r}0.001 \\
-0.013 \\
0.018 \\
-0.033\end{array}$ & $\begin{array}{r}0.494 \\
-3.237 \\
3.346 \\
-0.341\end{array}$ & $\begin{array}{l}0.002 \\
0.004 \\
0.005 \\
0.096\end{array}$ & $\begin{array}{r}-0.001 \\
-0.008 \\
0.002 \\
-0.666\end{array}$ & $\begin{array}{r}-0.112 \\
-0.602 \\
0.241 \\
-2.599\end{array}$ & $\begin{array}{l}0.009 \\
0.014 \\
0.009 \\
0.256\end{array}$ & $\begin{array}{l}0.003 \\
0.005 \\
0.012 \\
0.085\end{array}$ & $\begin{array}{l}0.443 \\
0.524 \\
1.794 \\
1.156\end{array}$ & $\begin{array}{l}0.007 \\
0.010 \\
0.007 \\
0.073\end{array}$ \\
\hline \multicolumn{10}{|c|}{ ENVIRONMENTAL DISAMENITIES } \\
\hline $\begin{array}{l}\text { AGE DEPENDENCY } \\
\text { ULEMPLOYMEKT } \\
\text { HONWHITE } \\
\text { CRIME } \\
\text { CLIMATE } \\
\text { HOUSING }\end{array}$ & $\begin{array}{r}-0.109 \\
-0.000 \\
0.005 \\
0.012 \\
0.004 \\
-0.064\end{array}$ & $\begin{array}{r}-2.149 \\
-0.178 \\
1.321 \\
1.422 \\
0.119 \\
-2.004\end{array}$ & $\begin{array}{l}0.051 \\
0.002 \\
0.004 \\
0.008 \\
0.030 \\
0.032\end{array}$ & $\begin{array}{r}-0.089 \\
-0.006 \\
0.005 \\
-0.007 \\
-0.005 \\
-0.025\end{array}$ & $\begin{array}{r}-0.488 \\
-1.327 \\
0.205 \\
-0.340 \\
-0.103 \\
-0.362\end{array}$ & $\begin{array}{l}0.182 \\
0.005 \\
0.023 \\
0.019 \\
0.051 \\
0.070\end{array}$ & $\begin{array}{r}-0.073 \\
-0.004 \\
0.025 \\
0.013 \\
0.073 \\
-0.055\end{array}$ & $\begin{array}{r}-0.541 \\
-1.137 \\
1.367 \\
0.956 \\
1.697 \\
-1.069\end{array}$ & $\begin{array}{l}0.134 \\
0.003 \\
0.018 \\
0.014 \\
0.043 \\
0.051\end{array}$ \\
\hline \multicolumn{10}{|l|}{ ACCESSIBILITY } \\
\hline $\begin{array}{l}\text { GRAVITY } \\
\text { CONTIGUOUS } \\
\text { POPULATION }\end{array}$ & $\begin{array}{r}0.087 \\
-0.744 \\
-1.028\end{array}$ & $\begin{array}{r}5.314 \\
-1.304 \\
-51.999\end{array}$ & $\begin{array}{l}0.016 \\
0.571 \\
0.020\end{array}$ & $\begin{array}{r}0.073 \\
-2.318 \\
-1.016\end{array}$ & $\begin{array}{r}5.673 \\
-1.790 \\
-24.281\end{array}$ & $\begin{array}{l}0.013 \\
1.295 \\
0.042\end{array}$ & $\begin{array}{r}0.077 \\
-1.639 \\
-0.976\end{array}$ & $\begin{array}{r}6.863 \\
-1.482 \\
-36.347\end{array}$ & $\begin{array}{l}0.011 \\
1.106 \\
0.027\end{array}$ \\
\hline $\begin{array}{l}\text { F-VALUE } \\
\text { PROB > } \\
\text { R SQUARE } \\
\text { ADJUSTED R } \\
\text { EXPLAINED SUA SQUARES } \\
\text { ERROR SUM SOUARES }\end{array}$ & $\begin{array}{r}7364.278 \\
0.000 \\
0.954 \\
0.953 \\
12709 \\
620\end{array}$ & & & $\begin{array}{r}645.400 \\
0.000 \\
0.721 \\
0.720 \\
3109 \\
1205\end{array}$ & & & $\begin{array}{r}293.007 \\
0.000 \\
0.782 \\
0.782 \\
4512 \\
1255\end{array}$ & & \\
\hline
\end{tabular}




\section{LIST D11}

LIST OF STANDARD ERRORS FOR ADJACENT LABOR IN-MIGRATION BASIC EMPLOYMENT MODEL

\begin{tabular}{|c|c|c|c|c|c|c|c|c|c|}
\hline \multirow{2}{*}{ - } & \multicolumn{2}{|c|}{$1960-65$} & \multicolumn{3}{|c|}{$1965-70$} & \multicolumn{4}{|c|}{$1970-75$} \\
\hline & BETR & T for Ho: & SE & BETA & T for Ho: & SE & BETA & T for Ho: & SE \\
\hline CONSTAHT & 2.620 & 20.323 & 0.129 & 0.674 & 2.030 & 0.332 & 1.789 & 6.290 & 0.284 \\
\hline \multicolumn{10}{|l|}{ EXOGENOUS VARIABLES } \\
\hline $\begin{array}{l}\text { LABOR AIGRATION FLOUS } \\
\text { NOHBASIC EMPLOYHEMT }\end{array}$ & $\begin{array}{r}-0.063 \\
0.565\end{array}$ & $\begin{array}{r}-3.951 \\
7.733\end{array}$ & $\begin{array}{l}0.016 \\
0.073\end{array}$ & $\begin{array}{l}-0.184 \\
-0.780\end{array}$ & $\begin{array}{r}-4.815 \\
-10.667\end{array}$ & $\begin{array}{l}0.038 \\
0.073\end{array}$ & $\begin{array}{l}-0.168 \\
-0.611\end{array}$ & $\begin{array}{l}-5.498 \\
-9.358\end{array}$ & $\begin{array}{l}0.031 \\
0.065\end{array}$ \\
\hline \multicolumn{10}{|l|}{ IMDEPERDENT VARIABLES } \\
\hline $\begin{array}{l}\text { AGRICULTURAL SERVICES } \\
\text { ROUTIHE MANUFACTURIHG } \\
\text { PROOUCER } \\
\text { EHERGY } \\
\text { WAGES } \\
\text { FREEWAY }\end{array}$ & $\begin{array}{r}-0.033 \\
-0.460 \\
0.160 \\
0.141 \\
0.723 \\
-0.171\end{array}$ & $\begin{array}{r}-1.317 \\
-13.163 \\
1.949 \\
3.183 \\
6.365 \\
-3.801\end{array}$ & $\begin{array}{l}0.025 \\
0.035 \\
0.082 \\
0.044 \\
0.114 \\
0.045\end{array}$ & $\begin{array}{r}-0.610 \\
-0.037 \\
0.468 \\
0.849 \\
0.245 \\
0.406\end{array}$ & $\begin{array}{r}-15.012 \\
-1.037 \\
4.932 \\
12.378 \\
2.778 \\
4.559\end{array}$ & $\begin{array}{l}0.041 \\
0.036 \\
0.095 \\
0.069 \\
0.088 \\
0.089\end{array}$ & $\begin{array}{r}-0.583 \\
-0.031 \\
0.556 \\
1.030 \\
0.458 \\
0.474\end{array}$ & $\begin{array}{r}-16.661 \\
-1.016 \\
6.787 \\
16.753 \\
6.215 \\
6.447\end{array}$ & $\begin{array}{l}0.035 \\
0.030 \\
0.082 \\
0.061 \\
0.074 \\
0.073\end{array}$ \\
\hline $\begin{array}{l}\text { F VALUE } \\
\text { PROB }> \\
\text { R SOUARE } \\
\text { ADJUSTED R } \\
\text { EXPLAINED SUM SOUARES } \\
\text { ERROR SUM SOUARES }\end{array}$ & $\begin{array}{r}92.216 \\
0.000 \\
0.125 \\
0.124 \\
1019 \\
7152\end{array}$ & & & $\begin{array}{r}90.551 \\
0.000 \\
0.162 \\
0.160 \\
5824 \\
5204\end{array}$ & & & $\begin{array}{r}147.887 \\
0.000 \\
0.180 \\
0.179 \\
1793 \\
8183\end{array}$ & & \\
\hline
\end{tabular}


TABLE D12

LIST OF STANDARD ERROR FOR ADJACENT LABOR IN-MIGRATION NONBASIC EMPLOYMENT MODEL

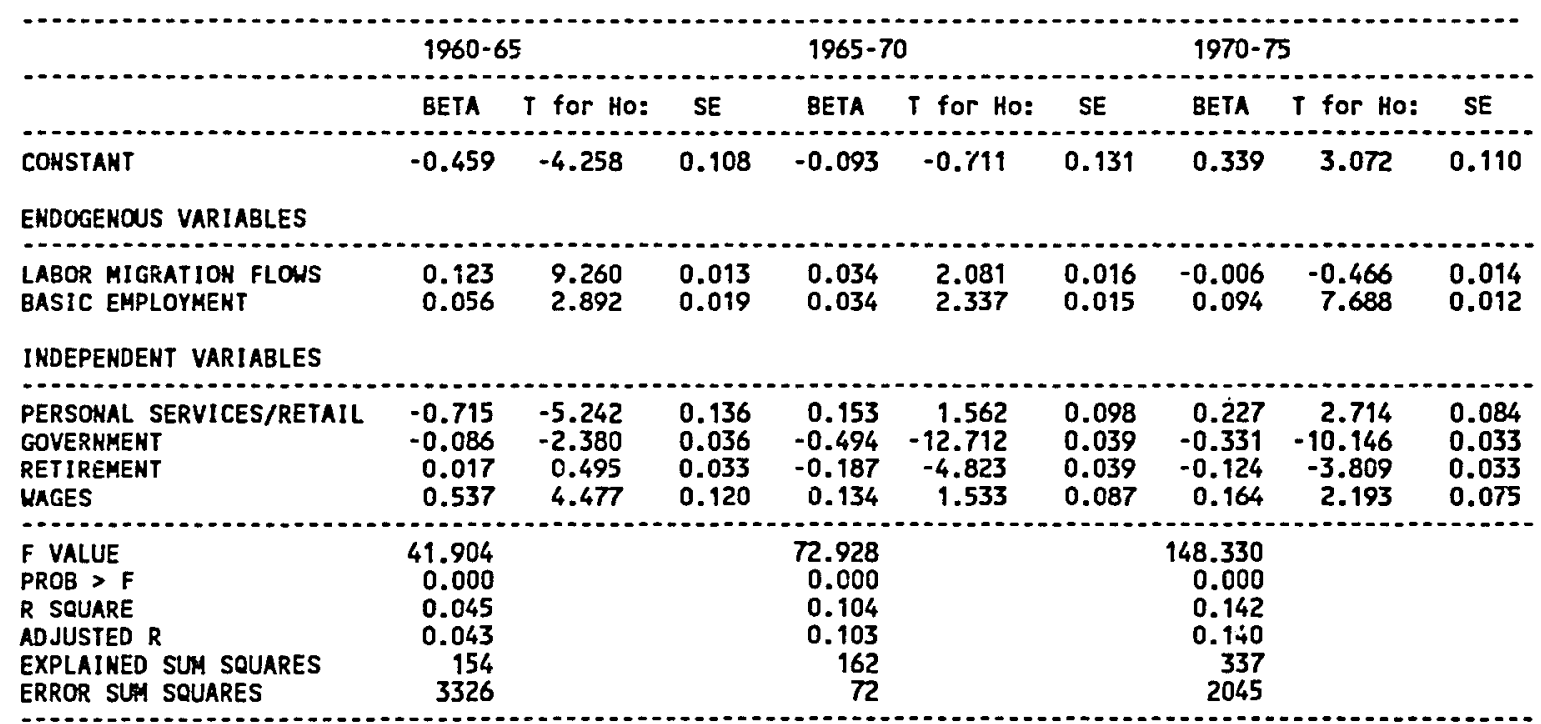


TABLE D13

LIST OF STANDARD ERROR FOR METRO $<500,000$ LABOR OUT-MIGRATION MODEL

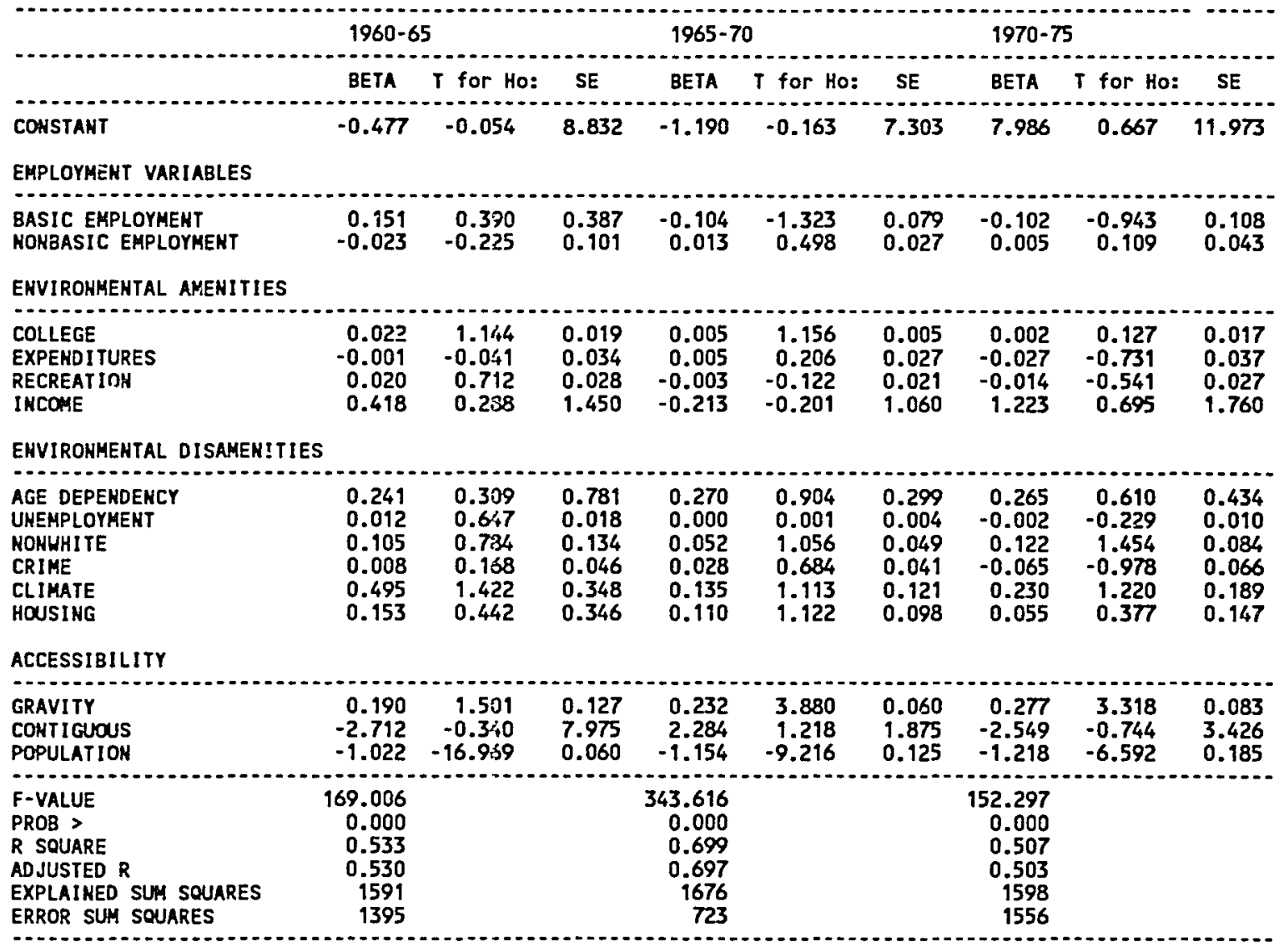




\section{LIST D14}

LIST OF STANDARD ERROR FOR METRO $<500,000$ LABOR OUT-MIGRATION BASIC EMPLOYMENT MODEL

\begin{tabular}{|c|c|c|c|c|c|c|c|c|c|}
\hline & \multicolumn{2}{|c|}{$1960-65$} & \multicolumn{3}{|c|}{$1965-70$} & \multicolumn{3}{|c|}{$1970-75$} & \multirow[b]{2}{*}{ SE } \\
\hline & BETA & $T$ for Ho: & SE & BETA & T for Ho: & SE & BETA & T for Ho: & \\
\hline CONSTANT & 3.739 & 63.303 & 0.059 & 3.765 & 5.604 & 0.672 & 5.883 & 11.075 & 0.531 \\
\hline \multicolumn{10}{|l|}{ ENDOGENOUS VARIABLES } \\
\hline $\begin{array}{l}\text { LABOR HIGRATION FLOWS } \\
\text { HONBASIC EMPLOYMENT }\end{array}$ & $\begin{array}{l}0.102 \\
0.021\end{array}$ & $\begin{array}{r}12.179 \\
1.621\end{array}$ & $\begin{array}{l}0.008 \\
0.013\end{array}$ & $\begin{array}{r}0.627 \\
-0.509\end{array}$ & $\begin{array}{r}6.654 \\
-19.720\end{array}$ & $\begin{array}{l}0.094 \\
0.026\end{array}$ & $\begin{array}{r}0.557 \\
-0.590\end{array}$ & $\begin{array}{r}7.052 \\
-29.669\end{array}$ & $\begin{array}{l}0.079 \\
0.020\end{array}$ \\
\hline \multicolumn{10}{|l|}{ INDEPENDENT VARIAâLES } \\
\hline $\begin{array}{l}\text { AGRICULTURAL SERVICES } \\
\text { ROUTINE MANUFACTURING } \\
\text { NOH-ROUTINE MANUFACTURING } \\
\text { PROOUCER } \\
\text { EHERGY } \\
\text { WAGES } \\
\text { FREEWAY }\end{array}$ & $\begin{array}{r}0.215 \\
0.691 \\
-0.091 \\
1.017 \\
0.434 \\
-2.090 \\
-0.276\end{array}$ & $\begin{array}{r}20.450 \\
19.183 \\
-9.317 \\
29.820 \\
17.515 \\
-27.266 \\
-28.821\end{array}$ & $\begin{array}{l}0.011 \\
0.036 \\
0.010 \\
0.034 \\
0.025 \\
0.077 \\
0.010\end{array}$ & $\begin{array}{r}0.175 \\
1.320 \\
-0.201 \\
1.205 \\
0.788 \\
-3.358 \\
-0.121\end{array}$ & $\begin{array}{r}2.392 \\
7.600 \\
-3.441 \\
6.625 \\
5.085 \\
-8.764 \\
-1.586\end{array}$ & $\begin{array}{l}0.073 \\
0.174 \\
0.058 \\
0.182 \\
0.155 \\
0.383 \\
0.076\end{array}$ & $\begin{array}{r}0.220 \\
1.510 \\
-0.234 \\
1.414 \\
0.928 \\
-3.724 \\
-0.140\end{array}$ & $\begin{array}{r}3.501 \\
10.490 \\
-4.667 \\
8.963 \\
7.213 \\
-11.356 \\
-2.184\end{array}$ & $\begin{array}{l}0.063 \\
0.144 \\
0.050 \\
0.158 \\
0.129 \\
0.328 \\
0.064\end{array}$ \\
\hline $\begin{array}{l}\text { F VALUE } \\
\text { PROB }> \\
R \text { SQUARE } \\
\text { ADJUSTED R } \\
\text { EXPLAINEO SUM SQUARES } \\
\text { ERROR SUM SQUARES }\end{array}$ & $\begin{array}{r}551.154 \\
0.000 \\
0.690 \\
0.689 \\
162 \\
73\end{array}$ & & & $\begin{array}{r}181.433 \\
0.000 \\
0.423 \\
0.420 \\
3789 \\
5175\end{array}$ & & & $\begin{array}{r}297.131 \\
0.000 \\
0.545 \\
0.544 \\
4421 \\
3686\end{array}$ & & \\
\hline
\end{tabular}




\section{LIST D15}

LIST OF STANDARD ERRORS FOR METRO < 500,000 LABOR OUT-MIGRATION NONBASIC EMPLOYMENT

\begin{tabular}{|c|c|c|c|c|c|c|c|c|c|}
\hline & \multicolumn{2}{|c|}{$1960-65$} & \multicolumn{3}{|c|}{$1965-70$} & \multicolumn{4}{|c|}{$1970-\pi 5$} \\
\hline & BETA & T for Ho: & SE & BETA & $T$ for Ho: & SE & BETA & $T$ for Ho: & SE \\
\hline COASTANT & -3.746 & -19.889 & 0.188 & 5.569 & 2.287 & 2.435 & 7.188 & 4.488 & 1.602 \\
\hline \multicolumn{10}{|l|}{ EHDOGENOUS VARIABLES } \\
\hline $\begin{array}{l}\text { LABOR MIGRATION FLOUS } \\
\text { BASIC EMPLOYMEHT }\end{array}$ & $\begin{array}{l}0.090 \\
1.331\end{array}$ & $\begin{array}{r}2.881 \\
38.151\end{array}$ & $\begin{array}{l}0.031 \\
0.035\end{array}$ & $\begin{array}{r}1.501 \\
-1.935\end{array}$ & $\begin{array}{r}3.040 \\
-12.252\end{array}$ & $\begin{array}{l}0.494 \\
0.158\end{array}$ & $\begin{array}{r}1.007 \\
-1.616\end{array}$ & $\begin{array}{r}3.298 \\
-20.239\end{array}$ & $\begin{array}{l}0.305 \\
0.080\end{array}$ \\
\hline \multicolumn{10}{|l|}{ IKDEPENDENT VARIABLES } \\
\hline $\begin{array}{l}\text { PERSONAL SERVICES/RETAIL } \\
\text { GOVERNMENT } \\
\text { RETIREHENT } \\
\text { WAGES }\end{array}$ & $\begin{array}{r}-1.293 \\
0.145 \\
0.032 \\
1.266\end{array}$ & $\begin{array}{r}-3.902 \\
3.711 \\
0.443 \\
3.637\end{array}$ & $\begin{array}{l}0.331 \\
0.039 \\
0.073 \\
0.348\end{array}$ & $\begin{array}{r}-0.758 \\
-0.150 \\
-1.710 \\
1.683\end{array}$ & $\begin{array}{r}-0.321 \\
-0.516 \\
-2.314 \\
0.632\end{array}$ & $\begin{array}{l}2.363 \\
0.291 \\
0.743 \\
2.663\end{array}$ & $\begin{array}{r}-0.315 \\
-0.061 \\
-1.271 \\
1.149\end{array}$ & $\begin{array}{r}-0.182 \\
-0.291 \\
-2.574 \\
0.593\end{array}$ & $\begin{array}{l}1.728 \\
0.210 \\
0.494 \\
1.937\end{array}$ \\
\hline $\begin{array}{l}\text { F VALUE } \\
\text { PROB > F } \\
\text { R SQUARE } \\
\text { AD JUSTED R } \\
\text { EXPLAINED SUM SQUARES } \\
\text { ERROR SUM SQUARES }\end{array}$ & $\begin{array}{r}292.701 \\
0.000 \\
0.440 \\
0.439 \\
426 \\
542\end{array}$ & & & $\begin{array}{r}147.437 \\
0.000 \\
0.284 \\
0.282 \\
8169 \\
20621\end{array}$ & & & $\begin{array}{r}296.248 \\
0.000 \\
0.443 \\
0.442 \\
8341 \\
296\end{array}$ & & \\
\hline
\end{tabular}




\section{LIST D16}

\section{LIST OF STANDARD ERROR FOR METRO $<500,000$}

LABOR IN-MIGRATION MODEL

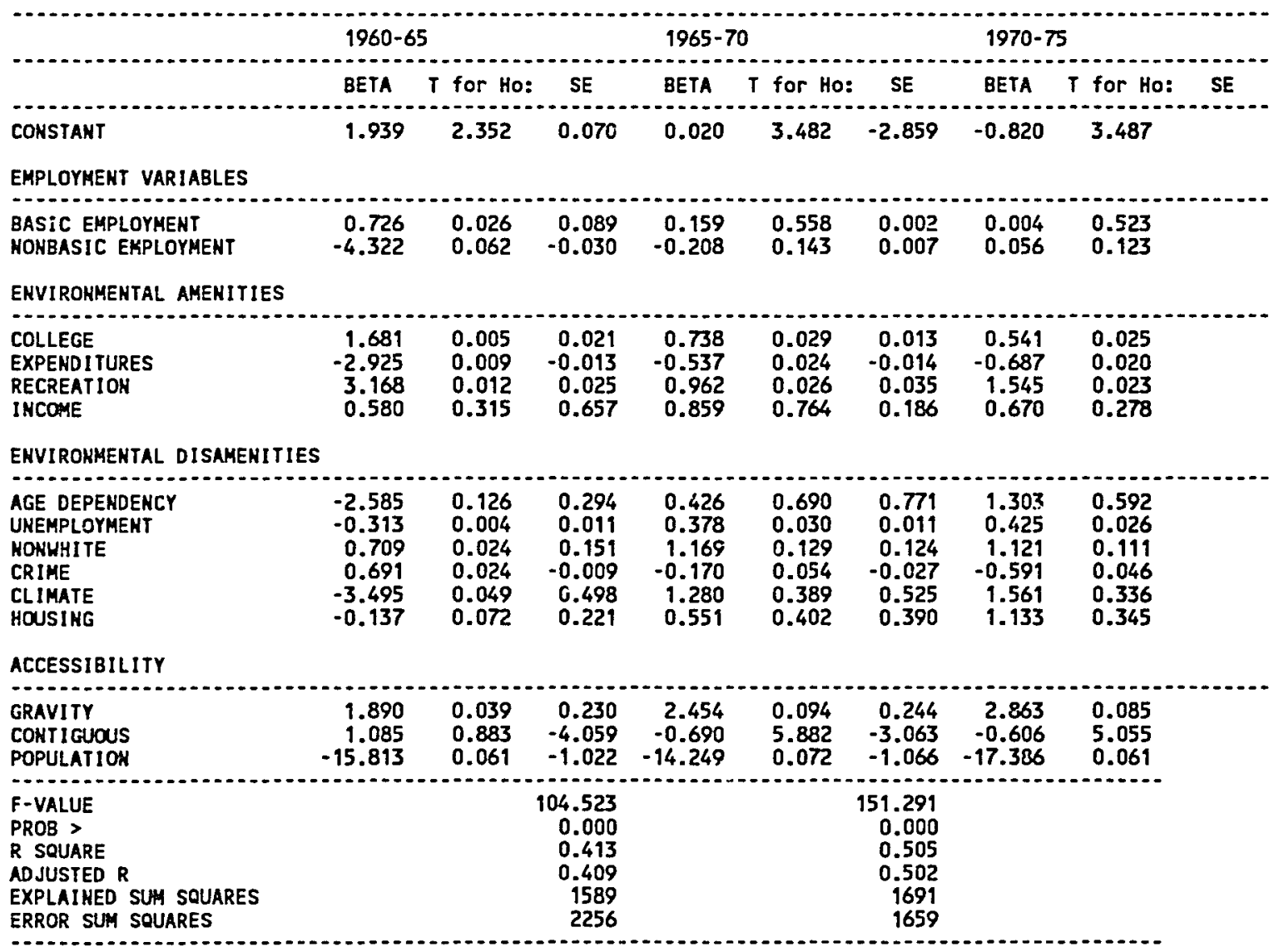


LIST D17

LIST OF STANDARD ERROR FOR METRO $<500,000$ LABOR IN-MIGRATION BASIC EMPLOYMENT MODEL

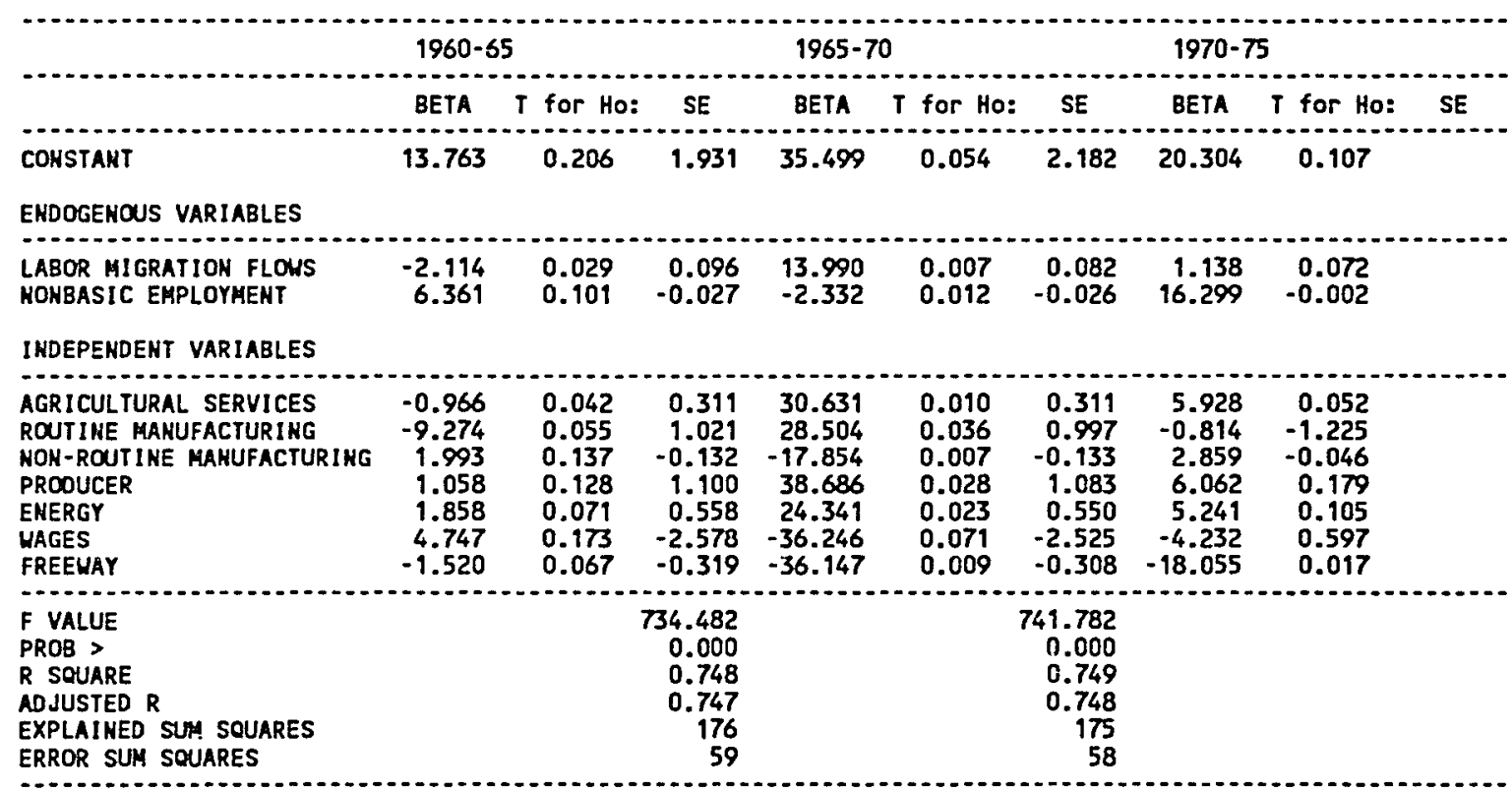




\section{LIST D18}

LIST OF STANDARD ERROR FOR METRO < 500,000 LABOR IN-MIGRATION NONBASIC EMPLOYMENT MODEL

\begin{tabular}{|c|c|c|c|c|c|c|c|c|c|}
\hline & \multicolumn{3}{|c|}{$1960-65$} & \multicolumn{2}{|c|}{$1965-70$} & \multicolumn{4}{|c|}{$1970-75$} \\
\hline & BETA & T for Ho & SE & BETA & $T$ for Ho & SE & BETA & T for Ho: & SE \\
\hline CONSTANT & -5.158 & 0.165 & -0.253 & -1.545 & 0.163 & -0.176 & -1.090 & 0.962 & \\
\hline \multicolumn{10}{|l|}{ ENDOGENOUS VARIABLES } \\
\hline $\begin{array}{l}\text { LABOR MIGRATION FLOWS } \\
\text { BASIC EMPLOYMENT }\end{array}$ & $\begin{array}{l}2.497 \\
3.664\end{array}$ & $\begin{array}{l}0.020 \\
0.028\end{array}$ & $\begin{array}{l}0.107 \\
1.332\end{array}$ & $\begin{array}{r}3.662 \\
38.411\end{array}$ & $\begin{array}{l}0.029 \\
0.035\end{array}$ & $\begin{array}{l}0.062 \\
1.333\end{array}$ & $\begin{array}{r}2.325 \\
38.641\end{array}$ & $\begin{array}{l}0.027 \\
0.034\end{array}$ & \\
\hline \multicolumn{10}{|l|}{ IHDEPEKDENT VARIABLES } \\
\hline $\begin{array}{l}\text { PERSONAL SERVICES/RETAIL } \\
\text { GOVERHMENT } \\
\text { RETIREMENT } \\
\text { HAGES }\end{array}$ & $\begin{array}{r}3.629 \\
-3.371 \\
0.609 \\
-4.464\end{array}$ & $\begin{array}{l}0.104 \\
0.054 \\
0.050 \\
0.097\end{array}$ & $\begin{array}{r}-1.533 \\
0.118 \\
0.019 \\
1.533\end{array}$ & $\begin{array}{r}-4.469 \\
2.930 \\
0.272 \\
4.287\end{array}$ & $\begin{array}{l}0.343 \\
0.040 \\
0.069 \\
0.357\end{array}$ & $\begin{array}{r}-1.578 \\
0.118 \\
0.117 \\
1.508\end{array}$ & $\begin{array}{r}-4.461 \\
2.836 \\
1.769 \\
4.096\end{array}$ & $\begin{array}{l}0.354 \\
0.042 \\
0.066 \\
0.368\end{array}$ & \\
\hline $\begin{array}{l}\text { F VALUE } \\
\text { PROB }>F \\
\text { R SQUARE } \\
\text { ADJUSTED R } \\
\text { EXPLAINED SUM SQUARES } \\
\text { ERROR SUM SQUARES }\end{array}$ & & & $\begin{array}{r}293.670 \\
0.000 \\
0.441 \\
0.439 \\
427 \\
542\end{array}$ & & & $\begin{array}{r}294.296 \\
0.000 \\
0.441 \\
0.440 \\
426 \\
294\end{array}$ & & & \\
\hline
\end{tabular}




\section{LIST D19}

LIST OF STANDARD ERROR FOR METRO $>500,000$ LABOR OUT-MIGRATION MODEL

\begin{tabular}{|c|c|c|c|c|c|c|c|c|c|}
\hline & \multicolumn{2}{|c|}{$1960-65$} & \multicolumn{3}{|c|}{$1965-70$} & \multicolumn{4}{|c|}{$1970-75$} \\
\hline & BETA & T for Ho: & SE & BETA & $T$ for Ho: & SE & BETA & $T$ for Ho: & SE \\
\hline DHSTAHT & -33.015 & -4.423 & 7.464 & -20.187 & -1.867 & 10.812 & -4.731 & -0.341 & 13.873 \\
\hline \multicolumn{10}{|l|}{ ERPLOYMENT VARIRBLES } \\
\hline $\begin{array}{l}\text { BASIC EMPLOYMENT } \\
\text { MONBASIC EKPLOYMEHT }\end{array}$ & $\begin{array}{l}-0.046 \\
-0.014\end{array}$ & $\begin{array}{l}-1.100 \\
-0.341\end{array}$ & $\begin{array}{l}0.042 \\
0.041\end{array}$ & $\begin{array}{l}-0.118 \\
-0.034\end{array}$ & $\begin{array}{l}-0.728 \\
-1.050\end{array}$ & $\begin{array}{l}0.162 \\
0.033\end{array}$ & $\begin{array}{l}-0.478 \\
-0.056\end{array}$ & $\begin{array}{l}-3.061 \\
-1.459\end{array}$ & $\begin{array}{l}0.156 \\
0.039\end{array}$ \\
\hline \multicolumn{10}{|l|}{ ENVIRONMENTAL AMENITIES } \\
\hline $\begin{array}{l}\text { COLLEGE } \\
\text { EXPENDI IURES } \\
\text { RECREATION } \\
\text { I HCOAE }\end{array}$ & $\begin{array}{r}-0.026 \\
0.025 \\
0.130 \\
-4.779\end{array}$ & $\begin{array}{r}-2.020 \\
0.764 \\
2.855 \\
-4.088\end{array}$ & $\begin{array}{l}0.013 \\
0.026 \\
0.046 \\
1.019\end{array}$ & $\begin{array}{r}-0.022 \\
-0.050 \\
0.185 \\
-2.695\end{array}$ & $\begin{array}{r}-1.852 \\
-1.859 \\
3.958 \\
-1.998\end{array}$ & $\begin{array}{l}0.012 \\
0.027 \\
0.047 \\
1.349\end{array}$ & $\begin{array}{r}-0.016 \\
-0.059 \\
0.190 \\
-0.883\end{array}$ & $\begin{array}{r}-0.926 \\
-1.775 \\
3.356 \\
-0.474\end{array}$ & $\begin{array}{l}0.017 \\
0.033 \\
0.057 \\
1.863\end{array}$ \\
\hline \multicolumn{10}{|c|}{ ENVIRONMENTAL DISAMEMITIES } \\
\hline $\begin{array}{l}\text { AGE DEPENDENCY } \\
\text { UHEMPLOYMENT } \\
\text { NOHUHITE } \\
\text { CRIME } \\
\text { CLIHATE } \\
\text { HOUSING }\end{array}$ & $\begin{array}{r}-1.180 \\
-0.008 \\
0.119 \\
0.015 \\
-0.172 \\
-0.341\end{array}$ & $\begin{array}{r}-4.318 \\
-1.509 \\
2.732 \\
0.375 \\
-1.472 \\
-1.748\end{array}$ & $\begin{array}{l}0.273 \\
0.006 \\
0.043 \\
0.039 \\
0.117 \\
0.195\end{array}$ & $\begin{array}{r}-0.840 \\
-0.005 \\
0.053 \\
0.004 \\
0.026 \\
-0.074\end{array}$ & $\begin{array}{r}-1.769 \\
-0.815 \\
0.947 \\
0.120 \\
0.195 \\
-0.382\end{array}$ & $\begin{array}{l}0.475 \\
0.006 \\
0.056 \\
0.036 \\
0.135 \\
0.194\end{array}$ & $\begin{array}{r}0.191 \\
0.006 \\
-0.006 \\
-0.089 \\
-0.030 \\
0.058\end{array}$ & $\begin{array}{r}0.504 \\
0.904 \\
-0.129 \\
-2.317 \\
-0.193 \\
0.259\end{array}$ & $\begin{array}{l}0.380 \\
0.007 \\
0.044 \\
0.039 \\
0.155 \\
0.224\end{array}$ \\
\hline \multicolumn{10}{|l|}{ ACCESSIBILITY } \\
\hline $\begin{array}{l}\text { GRAVITY } \\
\text { CONTIGUOUS } \\
\text { POPULATIOH }\end{array}$ & $\begin{array}{r}0.252 \\
1.908 \\
-0.902\end{array}$ & $\begin{array}{r}6.690 \\
0.913 \\
-17.893\end{array}$ & $\begin{array}{l}0.038 \\
2.090 \\
0.050\end{array}$ & $\begin{array}{r}0.276 \\
4.742 \\
-1.033\end{array}$ & $\begin{array}{r}2.625 \\
2.176 \\
-3.085\end{array}$ & $\begin{array}{l}0.105 \\
2.179 \\
0.335\end{array}$ & $\begin{array}{r}0.563 \\
3.478 \\
-1.800\end{array}$ & $\begin{array}{r}4.669 \\
1.301 \\
-5.654\end{array}$ & $\begin{array}{l}0.121 \\
2.673 \\
0.318\end{array}$ \\
\hline $\begin{array}{l}\text { F-VALUE } \\
\text { PROS }> \\
R \text { SQUARE } \\
\text { ADJUSTED R } \\
\text { EXPLAIKED SUM SOUARES } \\
\text { ERROR SUM SOUARES }\end{array}$ & $\begin{array}{r}316.210 \\
0.000 \\
0.659 \\
0.657 \\
2117 \\
1097\end{array}$ & & & $\begin{array}{r}196.831 \\
0.000 \\
0.546 \\
0.543 \\
2380 \\
1983\end{array}$ & & & $\begin{array}{r}128.458 \\
0.000 \\
0.439 \\
0.436 \\
2130 \\
2719\end{array}$ & & \\
\hline
\end{tabular}


LIST D20

LIST OF STANDARD ERROR FOR METRO $>500,000$ LABOR OUT-MIGRATION BASIC EMPLOYMENT MODEL

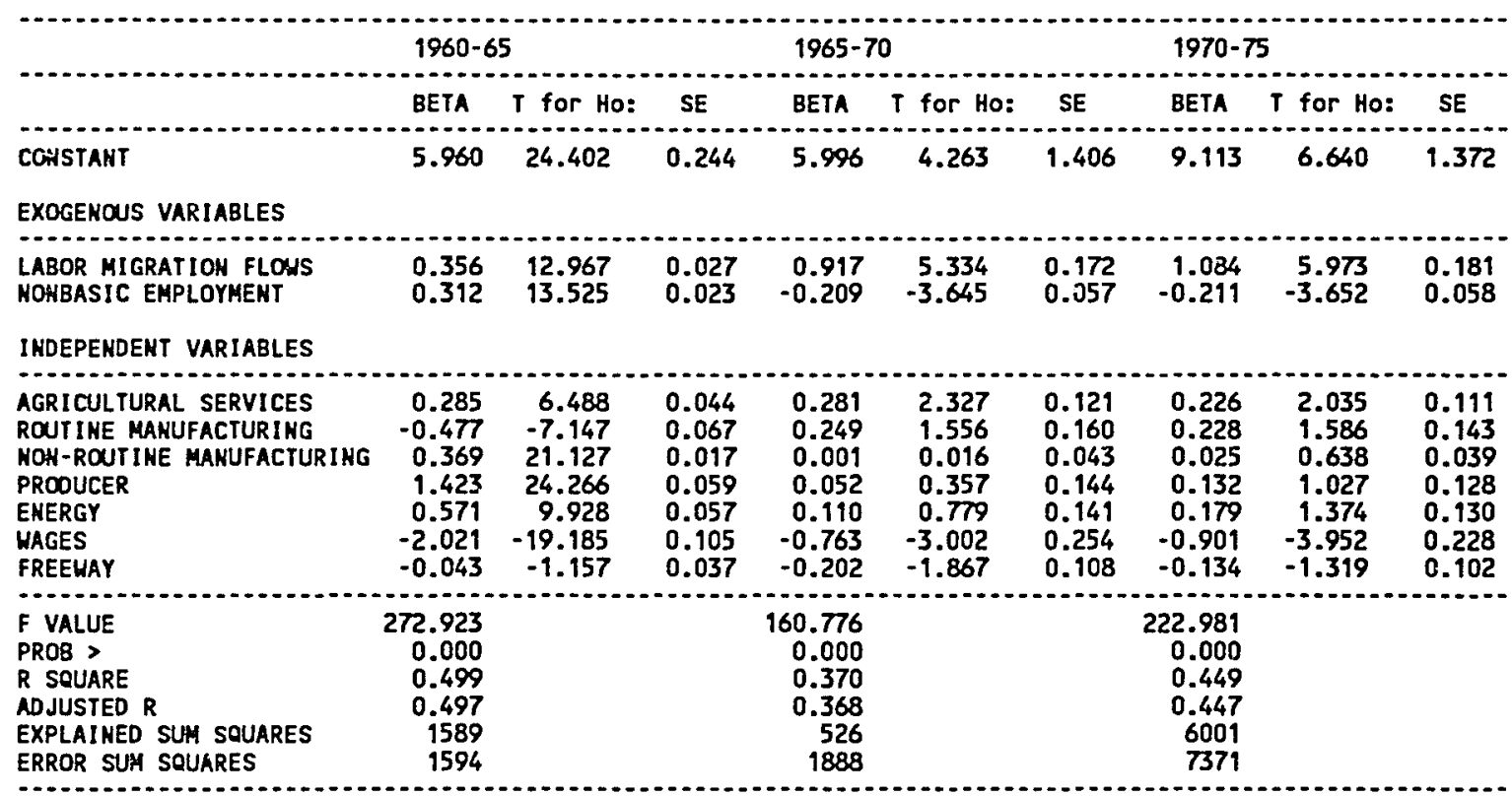


LIST D21

LIST OF STANDARD ERROR FOR METRO > 500,000 LABOR OUT-MIGRATION NONBASIC EMPLOYMENT MODEL

\begin{tabular}{|c|c|c|c|c|c|c|c|c|c|}
\hline & \multicolumn{2}{|c|}{$1960-65$} & \multicolumn{3}{|c|}{$1965-70$} & \multicolumn{3}{|c|}{$1970-75$} & \multirow[b]{2}{*}{ SE } \\
\hline & BETA & T for Ho: & SE & BETA & T for Ho: & SE & BETA & T for Ho: & \\
\hline COH'STANT & -4.590 & -16.632 & 0.276 & -11.574 & -11.572 & 1.000 & -10.131 & -10.157 & 0.997 \\
\hline \multicolumn{10}{|l|}{ ENDOGENOUS VARIABLES } \\
\hline $\begin{array}{l}\text { LABOR MIGRATION FLONS } \\
\text { BASIC EMPLOYHENT }\end{array}$ & $\begin{array}{r}-0.332 \\
0.282\end{array}$ & $\begin{array}{r}-15.274 \\
16.425\end{array}$ & $\begin{array}{l}0.022 \\
0.017\end{array}$ & $\begin{array}{l}-1.307 \\
-0.684\end{array}$ & $\begin{array}{l}-9.091 \\
-7.389\end{array}$ & $\begin{array}{l}0.144 \\
0.093\end{array}$ & $\begin{array}{l}-1.495 \\
-0.600\end{array}$ & $\begin{array}{r}-11.685 \\
-8.228\end{array}$ & $\begin{array}{l}0.128 \\
0.073\end{array}$ \\
\hline \multicolumn{10}{|l|}{ IHDEPENDEKT VAP.IABLES } \\
\hline $\begin{array}{l}\text { PERSOHAL SERUICES/RETAIL } \\
\text { GOVERHMENT } \\
\text { RETIREMENT } \\
\text { WAGES }\end{array}$ & $\begin{array}{r}1.586 \\
-1.097 \\
0.128 \\
-1.120\end{array}$ & $\begin{array}{r}7.998 \\
-11.484 \\
1.330 \\
-5.915\end{array}$ & $\begin{array}{l}0.198 \\
0.096 \\
0.097 \\
0.189\end{array}$ & $\begin{array}{r}4.506 \\
-1.413 \\
0.302 \\
-3.511\end{array}$ & $\begin{array}{r}10.214 \\
-6.753 \\
1.361 \\
-8.159 \\
\end{array}$ & $\begin{array}{l}0.441 \\
0.209 \\
0.222 \\
0.430\end{array}$ & $\begin{array}{r}4.273 \\
-1.491 \\
0.295 \\
-3.235\end{array}$ & $\begin{array}{r}10.651 \\
-7.797 \\
1.470 \\
-8.293 \\
\end{array}$ & $\begin{array}{l}0.401 \\
0.191 \\
0.201 \\
0.390\end{array}$ \\
\hline $\begin{array}{l}\text { F VALUE } \\
\text { PROB }>F \\
R \text { SQUARE } \\
\text { ADJUSTED R } \\
\text { EXPLAINED SUM SQUARES } \\
\text { ERROR SUA SOUARES }\end{array}$ & $\begin{array}{r}114.711 \\
0.000 \\
0.218 \\
0.216 \\
526 \\
1888\end{array}$ & & & $\begin{array}{r}501.189 \\
0.000 \\
0.549 \\
0.548 \\
11014 \\
9040\end{array}$ & & & $\begin{array}{r}629.685 \\
0.000 \\
0.605 \\
0.604 \\
11507 \\
7517\end{array}$ & & \\
\hline
\end{tabular}




\section{LIST D22}

LIST OF STANDARD ERROR FOR METRO $>500,000$ LABOR IN-MIGRATION MODEL

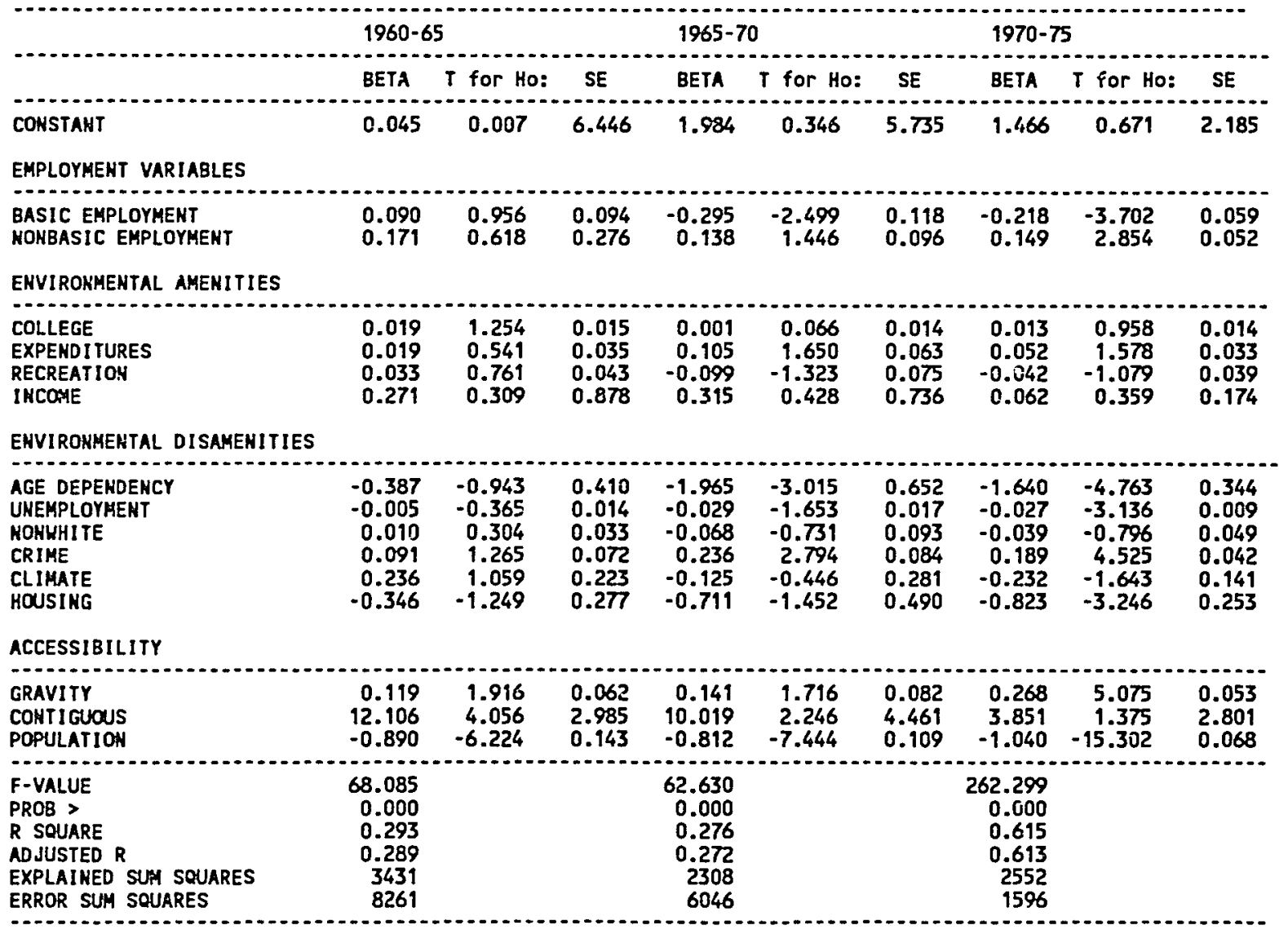




\section{LIST D23}

LIST OF STANDARD ERROR FOR METRO $>500,000$ LABOR IN-MIGRATION BASIC EMPLOYMENT MODEL

\begin{tabular}{|c|c|c|c|c|c|c|c|c|c|}
\hline \multirow{2}{*}{ 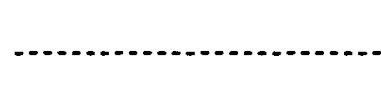 } & \multicolumn{2}{|c|}{$1960-65$} & \multicolumn{3}{|c|}{$1965-70$} & \multicolumn{3}{|c|}{$1970-75$} & \multirow[b]{2}{*}{ SE } \\
\hline & BETA & T for Ho: & SE & BETA & $T$ for Ho: & SE & BETA & $T$ for Ho: & \\
\hline COASTANT & 2.484 & 12.987 & 0.191 & 3.404 & 22.200 & 0.153 & 3.703 & 24.873 & 0.149 \\
\hline \multicolumn{10}{|l|}{ EXOGEHOUS VARIABLES } \\
\hline $\begin{array}{l}\text { LABOR HIGRATION FLOWS } \\
\text { HONBASIC EKPLOYHENT }\end{array}$ & $\begin{array}{r}-0.079 \\
0.491\end{array}$ & $\begin{array}{r}-2.894 \\
4.630\end{array}$ & $\begin{array}{l}0.027 \\
0.106\end{array}$ & $\begin{array}{l}0.300 \\
0.305\end{array}$ & $\begin{array}{l}16.548 \\
18.021\end{array}$ & $\begin{array}{l}0.018 \\
0.017\end{array}$ & $\begin{array}{l}0.314 \\
0.289\end{array}$ & $\begin{array}{l}17.731 \\
16.731\end{array}$ & $\begin{array}{l}0.018 \\
0.017\end{array}$ \\
\hline \multicolumn{10}{|l|}{ INDEPENDENT VARIABLES } \\
\hline $\begin{array}{l}\text { AGRICULTURAL SERVICES } \\
\text { ROUTINE MANUFACTURING } \\
\text { HOH-ROUTIHE MAHUFACTURIHG } \\
\text { PROOUCER } \\
\text { EHERGY } \\
\text { WAGES } \\
\text { FREEWAY }\end{array}$ & $\begin{array}{r}-0.056 \\
-0.462 \\
-0.046 \\
0.148 \\
0.172 \\
0.768 \\
-0.167\end{array}$ & $\begin{array}{r}-1.428 \\
-8.874 \\
-0.340 \\
1.224 \\
2.616 \\
4.692 \\
-2.768\end{array}$ & $\begin{array}{l}0.039 \\
0.052 \\
0.135 \\
0.121 \\
0.066 \\
0.164 \\
0.060\end{array}$ & $\begin{array}{r}0.160 \\
0.029 \\
0.255 \\
1.024 \\
0.245 \\
-1.878 \\
0.105\end{array}$ & $\begin{array}{r}5.130 \\
0.548 \\
19.294 \\
21.311 \\
5.413 \\
-21.929 \\
3.953\end{array}$ & $\begin{array}{l}0.031 \\
0.053 \\
0.013 \\
0.048 \\
0.045 \\
0.086 \\
0.027\end{array}$ & $\begin{array}{r}0.104 \\
-0.126 \\
0.320 \\
1.229 \\
0.305 \\
-2.055 \\
0.087\end{array}$ & $\begin{array}{r}3.210 \\
-2.340 \\
21.828 \\
24.097 \\
6.631 \\
-23.253 \\
3.154\end{array}$ & $\begin{array}{l}0.032 \\
0.054 \\
0.015 \\
0.051 \\
0.046 \\
0.088 \\
0.027\end{array}$ \\
\hline $\begin{array}{l}\text { F VALUE } \\
\text { PROB }> \\
R \text { SEUARE } \\
\text { ADJUSTED R } \\
\text { EXPLAINED SUA SQUARES } \\
\text { ERROR SUM SOUARES }\end{array}$ & $\begin{array}{r}41.543 \\
0.000 \\
0.132 \\
0.129 \\
489 \\
3223\end{array}$ & & & $\begin{array}{r}255.683 \\
0.000 \\
0.483 \\
0.481 \\
53 \\
1491\end{array}$ & & & $\begin{array}{r}280.287 \\
0.000 \\
0.506 \\
0.504 \\
1009 \\
987\end{array}$ & & \\
\hline
\end{tabular}


LIST D24

LIST OF STANDARD ERROR FOR METRO > 500,000 LABOR IN-MIGRATION NONBASIC EMPLOYMENT MODEL

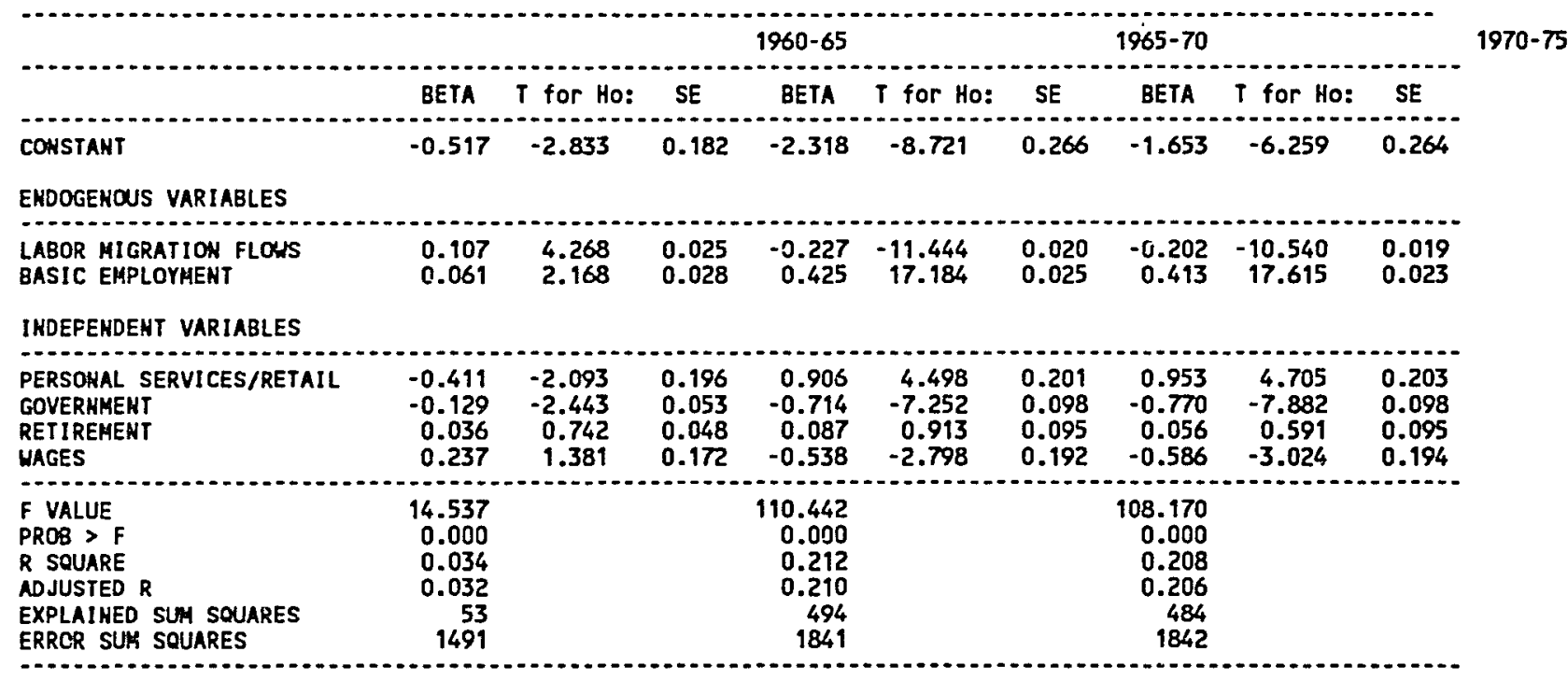

